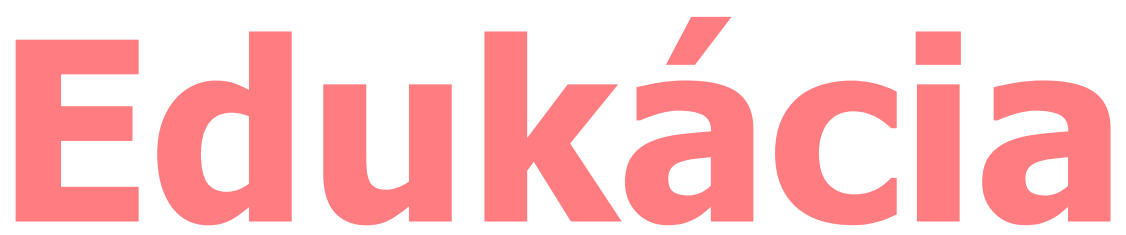

\title{
Vedecko-odborný časopis
}

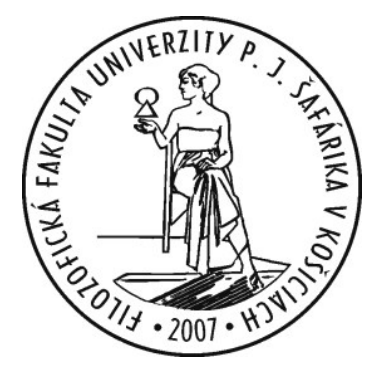

Vydavatel': Univerzita Pavla Jozefa Šafárika v Košiciach Ročník 4, číslo 2, 2021. ISSN 1339-8725 DOI: https://doi.org/10.33542/EDU2021-2-0 


\section{Profil časopisu Edukácia}

Vedecko-odborný časopis Edukácia je zameraný na problematiku vzdelávania a výchovy v oblasti základného, stredného a vysokého školstva. Zretel' kladie na súčasný stav a perspektívy edukačnej praxe, aktuálne aspekty pregraduálnej prípravy učitel'ov, sociálnej pedagogiky, špeciálnej pedagogiky, ako aj pedagogické a psychologické aspekty výchovy v základných výchovných inštitúciách z pohl'adu širokej pedagogickej verejnosti. Je určený vedeckým pracovníkom, mladým vysokoškolským učitel'om, doktorandom, ako aj odborným a pedagogickým pracovníkom s ciel'om prezentovat' trendy v edukácii a vyvolat’ diskusiu k aktuálnym otázkam prezentovaných oblastí výchovy a vzdelávania.

\section{Ciele vedecko-odborného časopisu Edukácia}

- prezentovat' súčasné postavenie a funkciu pedagóga v edukačnej praxi a jeho perspektívy,

- prezentovat' aktuálne otázky vzdelávania a výchovy z pohl'adu učitel'ov, sociálnych pedagógov, špeciálnych pedagógov a psychológov,

- $\quad$ prezentovat' inovácie v edukačnej praxi; analyzovat' stav a problémy prepájania teórie a praxe výchovy a vzdelávania vo vzt'ahu k moderným vyučovacím koncepciám,

- $\quad$ prezentovat' aktuálne trendy $v$ pregraduálnej príprave pedagógov,

- prezentovat' výsledky empirických výskumov z oblasti pedagogiky, sociálnej pedagogiky, špeciálnej pedagogiky a psychológie $v$ prostredí rodiny, školy a mimoškolských výchovných inštitúcií.

ISSN: $1339-8725$

Periodicita: dvakrát každý druhý rok

Cena: bezplatne

\section{Výkonný redaktor}

Doc. PaedDr. Renáta OROSOVÁ, PhD.

Filozofická fakulta, Univerzita Pavla Jozefa Šafárika, Košice, Slovensko

\section{Redakčná rada}

Prof. PhDr. Ingrid EMMEROVÁ, PhD.

Pedagogická fakulta, Katolícka univerzita, Ružomberok, Slovensko

Prof. PaedDr. Jarmila HONZíkOVÁ, Ph.D.

Fakulta pedagogická, Západočeská univerzita, PIzeň, Česko

Prof. PhDr. Jolana HRONCOVÁ, PhD.

Pedagogická fakulta, Univerzita Mateja Bela, Banská Bystrica, Slovensko

Prof. UAM dr hab. Michał JARNECKI

Fakulta pedagogická a výtvarných umení, Univerzita Adama Mickiewicza v Poznani, Kalisz, Pol'sko 
Prof. Koval PETRO, DrSc.

Prykarpatska Národná univerzita Vasyla Stefanyka, Ivano-Frankivsk, Ukrajina

Prof. Serhiy RUDYSHYN, DrSc.

Glukhivska Národná pedagogická univerzita Alexandra Dovzhenka, Hlukhiv, Ukrajina

Prof. Volodymyr STAROSTA, DrSc.

Filozofická fakulta, Univerzita Pavla Jozefa Šafárika, Košice, Slovensko

Doc. PhDr. Denisa LABISCHOVÁ, PhD.

Pedagogická fakulta, Ostravská univerzita, Ostrava, Česko

Doc. PaedDr. Lenka ROVŇANOVÁ, PhD.

Pedagogická fakulta, Univerzita Mateja Bela, Banská Bystrica, Slovensko

PaedDr. Janka FERENCOVÁ, PhD.

Pedagogická fakulta, Prešovská univerzita, Prešov, Slovensko

PaedDr. Michal NOVOCKÝ, PhD.

Filozofická fakulta, Univerzita Pavla Jozefa Šafárika, Košice, Slovensko

Ugrai JÁNOS, PhD.

Filozofická fakulta, Univerzita v Miškolci, Miškolc, Mad’arsko

Mgr. Katarína PETRÍKOVÁ, PhD.

Filozofická fakulta, Univerzita Pavla Jozefa Šafárika, Košice, Slovensko

\section{Recenzenti}

Prof. PaedDr. Anna HUDECOVÁ, PhD. (KU Ružomberok)

Prof. PhDr. Iveta KOVALČíKOVÁ, PhD. (PU Prešov)

Prof. PaedDr. Jozef LIBA, PhD. (PU Prešov)

Prof. PhDr. Milan PORTIK, PhD. (PU Prešov)

Prof. Volodymyr STAROSTA, DrSc. (UPJŠ Košice)

Prof. PhDr. Ol'ga ZÁPOTOČNÁ, CSc. (TU Trnava)

Doc. PhDr. Mgr. Barbora BAZALOVÁ, Ph.D. (MU Brno)

Doc. PaedDr. Vlasta BELKOVÁ, PhD. (UMB Banská Bystrica)

Doc. Mgr. Martin BRESTOVANSKÝ, PhD. (TU Trnava)

Doc. PhDr. Mário DULOVICS, PhD. (UMB Banská Bystrica)

Doc. Mgr. Lenka ĎURICOVÁ, PhD. (UMB Banská Bystrica)

Doc. PaedDr. Lívia HASAJOVÁ, PhD. (DTI Dubnica nad Váhom)

Doc. PhDr. Eva HOMOLOVÁ, PhD. (UMB Banská Bystrica)

Doc. PaedDr. Zlatica HUL'OVÁ, PhD. (KU Ružomberok)

Doc. PaedDr. Jana JAVORČíKOVÁ, PhD. (UMB Banská Bystrica)

Doc. PaedDr. Petra JESENSKÁ, PhD. (UMB Banská Bystrica)

Doc. PhDr. Viera KAČINOVÁ, PhD. (UCM Trnava)

Doc. PhDr. Janka KYSEL'OVÁ, PhD. (UMB Banská Bystrica)

Doc. PhDr. Daniel LANČARIČ, PhD. (UK Bratislava)

Doc. PaedDr. Milena LIPNICKÁ, PhD. (UMB Banská Bystrica)

Doc. PhDr. Július MATULČíK, CSc. (UK Bratislava)

Doc. Mgr. Lívia NEMCOVÁ, PhD. (UMB Banská Bystrica)

Doc. PaedDr. Renáta OROSOVÁ, PhD. (UPJŠ Košice)

Doc. PhDr. Zuzana PETROVÁ, PhD. (TU Trnava) 
Doc. PhDr. Ivana PIROHOVÁ, PhD. (PU Prešov)

Doc. PaedDr. Lenka ROVŇANOVÁ, PhD. (UMB Banská Bystrica)

Doc. PaedDr. Eva SEVERINI, PhD. (UK Bratislava)

Doc. PhDr. Marián ŠPAJDEL, PhD. (TU Trnava)

Doc. Mgr. Renáta TIMKOVÁ, PhD. (UPJŠ Košice)

PaedDr. Monika BROZMANOVÁ, PhD. (UMB Banská Bystrica)

PaedDr. Janka FERENCOVÁ, PhD. (PU Prešov)

PaedDr. Michal NOVOCKÝ, PhD. (UPJŠ Košice)

PaedDr. Erika NOVOTNÁ, PhD. (PU Prešov)

PaedDr. Štefan PETRÍK, PhD. (UMB Banská Bystrica)

PaedDr. Veronika VRABCOVÁ, PhD.

PhDr. Dana BUNTOVÁ, PhD. (UK Bratislava)

PhDr. Mgr. Lucia GALKOVÁ, PhD. (UMB Banská Bystrica)

RNDr. Kitti PÁLENÍKOVÁ, PhD. (UKF Nitra)

Mgr. Mária BELEŠOVÁ, PhD. (UK Bratislava)

Mgr. Zuzana BURÁKOVÁ, PhD. (UPJŠ Košice)

Mgr. Miriam DUBOVSKÁ, PhD. (UMB Banská Bystrica)

Mgr. Katarína DZURILLOVÁ, PhD. (KU Ružomberok)

Mgr. Matúš HORVÁTH, PhD. (UCM Trnava)

Mgr. Ivana HORVÁTHOVÁ, PhD. (UKF Nitra)

Mgr. Silvia HVOZDÍKOVÁ, PhD. (UKF Nitra)

Mgr. Imrich IŠTVAN, PhD. (PU Prešov)

Mgr. Lena IVANČOVÁ, PhD. (UPJŠ Košice)

Mgr. Miroslava KÖVEROVÁ, PhD. (UPJŠ Košice)

Mgr. Jana KOŽÁROVÁ, PhD. (PU Prešov)

Mgr. Ivana MARTINKOVÁ, PhD. (PU Prešov)

Mgr. Katarína PETRÍKOVÁ, PhD. (UPJŠ Košice)

Mgr. Július ROZENFELD, PhD. (UPJŠ Košice)

Mgr. Adriana SABOVIKOVÁ, PhD. (UPJŠ Košice)

Mgr. Anna SLATINSKÁ, PhD. (UMB Banská Bystrica)

Mgr. Lujza URBANCOVÁ, Ph.D. (UMB Banská Bystrica)

Mgr. Veronika VALKÓOVÁ, PhD. (UK Bratislava)

Mgr. Michaela SOUČEK VAŇOVÁ, PhD. (UMB Banská Bystrica)

Mgr. Gabriela VOJTEKOVÁ, PhD. (KU Ružomberok) 
Text neprešiel jazykovou úpravou. Za údaje a prípadné chyby v jednotlivých príspevkoch sú zodpovední ich autori.

\section{Kontakt}

Univerzita Pavla Jozefa Šafárika v Košiciach

Filozofická fakulta

Katedra pedagogiky

Moyzesova 9, 04001 Košice

Tel. 055/234 7172

Email: vychovaavzdelavanie@gmail.com

\section{Vydavatel':}

Univerzita Pavla Jozefa Šafárika v Košiciach

Vydavatel'stvo ŠafárikPress 


\section{OBSAH}

Daněk, A.: ROMSKÉ DĚTI V DĚTSKÉM DOMOVĚ KLÁNOVICE V LETECH 2010-2020

Mil'anová, J.: ANALÝZA STAVU A PROBLÉMOV PEDAGÓGOV PRI PREPÁJANÍ TEÓRIE A PRAXE VÝCHOVY A VZDELÁVANIA V SÚČASNOSTI SO ZAMERANÍM NA APLIKOVANIE METODIKY ESP NA HODINÁCH ANGLICKÉHO JAZYKA NA STREDNÝCH ODBORNÝCH ŠKOLÁCH

Niklová, M. - Zošáková, K.: KYBERŠIKANOVANIE AKO FORMA ONLINE RIZIKOVÉHO SPRÁVANIA A MOŽNOSTI JEHO PREVENCIE V ŠKOLÁCH.

Orosová, R. - Ganajová, M. - Puchalová, I.: DIAGNOSTICKÉ A REFLEXÍVNE KOMPETENCIE ŠTUDENTOV UČITEL'STVA $V$ PRAKTICKEJ PROFESIJNEJ PRÍPRAVE.

Pavlov, I. - Schubert, M.: ANDRAGOGICKÉ PORADENSTVO AKO INTEGRÁLNA SÚČAST̄ EDUKAČNÉHO PORADENSTVA

Petríková, K. - Orosová, R. - Novocký, M.: REFLEXIA VYUČOVACíCH VÝSTUPOV ŠTUDENTA UČITEL'STVA NA PEDAGOGICKEJ PRAXI

Prokopová, Z: DŮLEŽITOST FUNKČNÍHO KOMUNIKAČNÍHO TRÉNINKU U JEDINCŮ S PORUCHAMI AUTISTICKÉHO SPEKTRA A JINÝM VÝVOJOVÝM POSTIŽENÍM.

Sirotová, M. - Michvocíková, V.: IDENTIFIKÁCIA ZÁUJMU O ŠTÚDIUM ŠTUDIJNÝCH ODBOROV PEDAGOGICKÉHO ZAMERANIA V SÚČASNEJ VYSOKOŠKOLSKEJ EDUKÁCII.

Slováček, M. - Miňová, M.: OSOBNOSŤ PREDŠKOLSKÉHO (MONTESSORI) PEDAGÓGA A JEHO PRÍPRAVA

Stančeková, S.: UČITEL'OVA OSOBNÁ POTREBA ŠTRUKTÚRY A POSTOJE ŽIAKOV K UČITEL'OVI A NEMECKÉMU JAZYKU

Starosta, V. - Orosová, R.: DIAGNOSTICKÉ KOMPETENCIE ŠTUDENTOV UČITEL'STVA ROZVÍJANÉ METÓDOU MIKROVYUČOVANIA.

Šutovcová, L.: AKTIVIZUJÚCE METÓDY AKO NÁSTROJ ROZVÍJAJÚCI TVORIVÉ A KRITICKÉ MYSLENIE

Teleková, R.: ADAPTAČNÉ ŤAŽKOSTI ZAČíNAJÚCICH ŠKOLÁKOV V CENTRE DIAGNOSTICKEJ ČINNOSTI UČITEL'A.

Teleková, R.: ŠPECIFIKÁ PRÁCE UČITEL'A V PROCESE ADAPTÁCIE ŽIAKOV NA ZAČIATKU ŠKOLSKEJ DOCHÁDZKY 
Timková, R.: FONOLOGICKÉ KOMPETENCIE V PROCESE OSVOJOVANIA SI ANGLICKÉHO JAZYKA NA ZÁKLADNÝCH A STREDNÝCH ŠKOLÁCH NA SLOVENSKU - POHL'AD UČIACEHO SA ...................................................... 135

Timková, R.: ŠPECIFIKÁ VÝUČBY SLOVENČINY AKO CUDZIEHO JAZYKA Z POHLADU PEDAGÓGA. 141

Trymlová, J. - Pěchoučková, š. - Frank, J.: ČINNOSTI NA UŽITÍ SUDOKU VE VÝUCE MATEMATIKY NA 1. STUPNI ZÁKLADNÍ ŠKOLY 145

Uhrinová, M. - Prachárová, I. - Tirpák, J.: ZVYŠOVANIE EFEKTIVITY VÝUČBY V PRIMÁRNOM PRÍRODOVEDNOM VZDELÁVANÍ PROSTREDNÍCTVOM ZÁŽITKOVÉHO UČENIA SA. 150

Zajacová, M.: SÚČASNÁ ÚLOHA A POSTAVENIE UČITEL'A ANGLICKÉHO JAZYKA NA STREDNEJ ODBORNEJ ŠKOLE 159 


\title{
ROMSKÉ DĚTI V DĚTSKÉM DOMOVĚ KLÁNOVICE V LETECH 2010-2020
}

\section{ROMA CHILDREN IN THE CHILDREN'S HOME KLANOVICE DURING A PERIOD 2010-2020}

\author{
Alois Daněk \\ Katedra speciální pedagogiky, Pedagogická fakulta, UK v Prahe
}

\begin{abstract}
:
This work aims to offer the reader the insight view into the issue of the education and upbringing of Roma children in the environment of institutional facilities for institutional care. We chose qualitative research methods. Information provided interviews, observations and analysis of pedagogical documentation. Our results point to several challenges for Roma children in our society. Although an inclusive concept of education should currently be the standard, respondents do not feel that way. In the discussion we will try to offer some educational and special educational methods that could improve the current situation.
\end{abstract}

\section{Key words:}

Roma, inclusion, specific educational needs, Feuerstein Instrumental Enrichment, Growth Mindset, language codes

\section{Úvod}

Autor pracuje v Dětském domově Klánovice jako vychovatel a metodik prevence. Velice často se setkává s otázkou, zdali je v domově mnoho Romů. Ptají se spoluobčané, pedagogové, lékaři i speciální pedagogové. Podle jejich přesvědčení jsou Romové hlavními obyvateli českých školských zařízení pro výkon ústavní výchovy. Tazatelé jsou velice překvapeni, když se dozví, že romských dětí není převažující většina. Příspěvek si klade si za cíl nabídnout čtenáři vhled do problematiky vzdělávání a výchovy romských dětí v prostředí školského zařízení pro výkon ústavní výchovy. Budeme se pohybovat výhradně mezi mantinely Dětského domova Klánovice v období 2010 až 2020, abychom se mohli opřít o živou praxi. Příspěvek bude rozdělen do dvou oddílů. Po úvodu představíme prostudovanou literaturu a použitou metodologii. Poté bude následovat krátká prezentace zkoumaného prostředí. Ve druhé části příspěvku bude prostor pro analýzu současného stavu výchovy a vzdělávání romských dětí v Dětském domově Klánovice. Na závěr shrneme naše zjištění. V diskuzi nad výsledky se pokusíme nabídnout speciálně pedagogické přístupy, které by mohly napomoci českému školství na cestě k inkluzivnímu pojetí edukace.

\section{Současný stav poznání a použitá metodologie}

$V$ současnosti je $\mathrm{k}$ dispozici poměrně široká škála zdrojů a literatury věnující se otázce Romů. Historické informace nám poskytly práce Hanzala a Horvátové. Aktuální situaci na poli výchovy a vzdělávání Romů se věnuje Šotolová a Nečas. Mnohou inspiraci jsme načerpali v knihách Hübschmannové a Lackové. Prostudované zdroje a literatura pro tuto práci nebyly pouze zaměřené čistě na problematiku Romů. $Z$ literatury speciálněpedagogické jmenujme Škovieru a Feuersteina. Jazykovým kódům se věnuje 
Bernstein a otázky nastavení mysli jsou doménou Dweckové. Využili jsme také řadu cizojazyčných zdrojů převážně zaměřených na inkluzivní vzdělávání, problematiku zpracovává např́klad Norwich a Nilholm. Cenným pramenem nám byla pedagogická dokumentace Dětského domova Klánovice, která je jinak pro výzkumníky nedostupná. Pro tento příspěvek jsme zvolili kombinaci kvalitativních výzkumných metod, jako rozhovory, pozorování a analýzu pedagogické dokumentace. Profitovali jsme ze znalosti zkoumaného prostředí. Použili jsme nestrukturované rozhovory, které umožňují flexibilně reagovat na aktuální situaci. Všechny děti byly požádány o souhlas $\mathrm{s}$ provedením rozhovoru a pozorování. Pozorování a rozhovory probíhaly na rodinných skupinkách za běžného provozu. Dále jsme provedli několik rozhovorů s ostatními vychovateli a pedagogy místní základní školy. Nepodařilo se nám kontaktovat rodinné příslušníky našich romských dětí, nicméně jsme byli schopni se spojit s několika bývalými romskými klienty Dětského domova Klánovice. Získané informace jsme zpracovali za pomoci zakotvené teorie.

\section{Dětský domov Klánovice}

Dětský domov Klánovice je školské zařízení pro výkon ústavní výchovy zřizované Magistrátem hlavního města Prahy. Na sedmi rodinných skupinkách zde žije 54 dětí. Jedná se o dětský domov rodinného typu, který je primárně určen pro děti bez závažných poruch chování. Je nutno zmínit skutečnost, že veřejnost laická i odborná často nemá jasno v jednotlivých druzích školských zařízeních. Stává se, že je používán všeobecný termín ústav, neodlišující dětský domov od dětského domova se školou, nebo diagnostického a výchovného ústavu. Což je hrubou chybou, nebot' každé školské zařízení má svůj specifický účel a je určeno pro jasně definovanou cílovou skupinu. Naprostá většina dětí přichází z rodin s nízkým sociokulturním statusem. $V$ posledních letech se poněkud změnilo věkové rozložení nově příchozích dětí, věk se zvýšil. Další změnou je zřetelný nárůst nově příchozích dětí, které vyžadují psychiatrickou péči. Nelze opomenout také změny národnostního složení domova, stoupá počet dětí různých národností. V současnosti v Dětském domově Klánovice žiji děti původem z Kazachstánu, Jemenu, Afganistánu, Běloruska, Slovenska, Vietnamu.

\section{Romské děti v Dětském domově Klánovice}

K dnešnímu dni žije $v$ Dětském domově Klánovice celkem deset dětí a mladých lidí, kteří pocházejí z rodin, kde figuruje alespoň jeden romský rodič. Zastoupení romských dětí $\checkmark$ Domově se v posledních deseti letech neustále pohybuje právě kolem deseti dětí. Zřídkakdy výrazněji poklesne, ale zažili jsme krátká časová období, kdy romských dětí bylo i patnáct. Mưžeme tedy tvrdit, že romské děti představuji přibližně 20 až $25 \%$ celkového počtu klánovických dětí. Podobná data jsme zaznamenali i v historii (Ústav školských informací, 1975, s. 44). Je tedy žrejmé, že $v$ žádném prípadě romské děti nepřevažují nad dětmi neromskými. $V$ našem výzkumu jsme se nejprve zaměřili na pưvodní rodinná prostředí našich romských dětí. Romské děti do Dětského domova přicházejí ze stejných důvodů, jako děti neromské, tedy z důvodu naprostého selhání rodiny. Je tedy třeba zdůraznit, že základním důvodem $\mathrm{k}$ umístění do dětského domova je disfunkční rodina. Nikoli dítě, jak se často zcela chybně tvrdí. Z našich dřívějších výzkumů jednoznačně vyplývá, že dítě si do dětského domova problémy přináší právě z původních rodinných prostředí (Daněk, 2019). V prostředí rodin s nízkým sociokulturním statusem se velice často setkáváme s mnoha negativními modely chování (Janský, 2014, s. 74). Je tristní skutečností, že drtivá většina rodičů nespolupracuje. Rodiče jsou přesvědčeni, že dítě bylo umístěno do domova neprávem a negují vlastní zavinění. Omluvu hledají v nespravedlivém sociálním osudu, v romském původu, nebo ve špatné finanční situaci. Vinu za jakékoli výchovné a vzdělávací potíže přenášejí na školské zařízení. Podobný prístup mưžeme místy zaznamenat v současném mediálním 
prístupu k ústavní výchově. Veřejnosti je prezentován obraz, kdy dítě trpí psychickou deprivací v nepodnětném prostředí ústavu. Proti tomuto postoji se musíme jasně ohradit. Označovat institucionální prostředí jako jednoznačně negativní není objektivní (Matějček, 2005, s. 137), děti samy často hodnotí život v dětském domově jako bezpečnější alternativu jejich původním rodinám. $V$ kazuistikách našich romských dětí můžeme najít alkoholismus rodičů, zneužívání návykových látek, kriminalitu, prostituci, nestálé prostředí, násilí domácí i na dětech. Značná část romských dívek byla v dětství pohlavně zneužita. U těchto dívek jsme zaznamenali rizikové sexuální chování. Mnoho dětí má přímou zkušenost $s$ kriminalitou, v několika případech je jejich rodiče do této činnosti aktivně zapojovali. Aktuálně tři rodiče jsou ve výkonu trestu. Děti vyrůstaly v prostředí, kde byla značná tolerance $\mathrm{k}$ celé paletě návykových látek. Až na výjimky romské děti do dětského domova přicházejí se silnou závislostí na tabáku. Velká část dětí má kladný vztah k alkoholu a v posledních pěti letech dokumentujeme prudký nárůst záchytu zneužívání návykových látek, především marihuany. Drogová problematika je přímo odpovědná za celou řadu problému našich dětí. Několik se jich narodilo rodičům alkoholikům, u dvou prípadů máme zdokumentované porodní abstinenční příznaky novorozence. U těchto dvou dětí se následně projevily závažné poruchy chování. $S$ rozmachem informačních technologií nám vzniká další oblast závislostního chování, a to závislost na sociálních sítích. Nicméně nelze tvrdit, že by výše uvedené potíže byly výhradní doménou romských dětí, identické potíže zaznamenáváme i u ostatních dětí našeho domova.

\section{Diskuze nad získanými výsledky}

$\checkmark$ našem výzkumu jsme informace získané z rozhovorů a pozorování komparovali se záznamy $v$ pedagogické dokumentaci. Na podkladě získaných dat můžeme tvrdit, že do Dětského domova Klánovice přicházejí romské děti z disfunkčních, tedy netypických romských rodin, proto nelze tyto děti vidět jako typické mladé Romy. $Z$ našeho šetření jsme zjistili, že romské děti v se Dětském domově Klánovice výrazně neliší od ostatních dětí. Ani v oblasti rizikového chování romské děti nevybočují. Nicméně vytěžená data poukázala na zajímavou skutečnost. Zatímco neromské děti nenávidí rodiče, protože jsou v dětském domově, romské děti nenávidí dětský domov, protože nejsou s rodiči. Neromské děti k nám často přicházejí citově deprivované se všemi následky z deprivace plynoucími. Romské dítě je v rodině milováno, vychováváno mnohem volněji, něž jsme zvyklí. Frekventovaně slýcháme od romských rodičů, jak dětem neustále opakují, že jsou jejich lásky a jsou pro ně vším. Romské děti se zdají oproti ostatním dětem stabilnější a vyrovnanější. Máme zdokumentovaný mnohem menší výskyt psychických potíží. Romské děti ale nemají osvojeny kompetence, které jsou v naší společnosti vyžadované. Romské děti mají potíže s přijímáním autorit, které nejsou součástí jejich rodiny. Mají svůj hodnotový systém, který není vždy v souladu se systémem většinovým. Při analýze pedagogické dokumentace jsme zjistili, že oproti neromským dětem romské děti mnohem méně využívají možnost setrvat $v$ dětském domově $v$ případě dalšího studia. Samostatnou kapitolou by mohl být prístup ke vzdělání. Romské děti mají problémy se samostatnou přípravou. Školní docházka a vzdělávací výsledky nejsou pro ně prioritou. $\checkmark$ mnoha prrípadech jsou první v celé rodinné historii, kdo dokončí základní vzdělání a pokračuje v dalším vzdělávání. Bývalí romští klienti dětského domova označili možnost dosažení vzdělání jako jeden z nejdůležitějších zisků jejich pobytu v dětském domově, zároveň ale poukázali na potíže se zapojením do běžného života po jejich odchodu z domova. Je třeba si sebekriticky přiznat, že naše země stále není připravena na multikulturní společnost. Je náročné přijmout skutečnost, že romské děti jsou členy jedné z nejdeprivovanější komunity a denně čelí diskriminaci a porušování lidských práv (Council of Europe, 2020). Jako většinová populace se musíme se otevřít a snažit se pochopit, jak naše předsudky fungují (Katz, 1978, s. 167). Můžeme se ale pokusit 
současný stav poněkud zlepšit za pomoci moderních pedagogických a speciálněpedagogických metod.

\section{Bernsteinova teorie jazykových kódů}

Bernstein v sedmdesátých letech minulého století rozpoutal v akademickém světě polemiku představením teorie jazykových kódů. Tvrdil, že jazyk je svázán se společenskou skupinou. Skupiny s vyšším sociálním statusem používají jazykový kód rozvinutý, skupiny se sociálním statusem nižším používají jazykový kód omezený (Bernstein, 2003). Po kritických připomínkách teorii zrevidoval a připustil, že jeden kód není nadřazen druhému a oba kódy jsou schopné předat identickou informaci. Nicméně tato teorie říká, že za pomoci jazykového kódu omezeného nelze operovat v prostředí jazykového kódu rozvinutého. A nyní si představme, že romské dítě přichází do školy, tedy do prostředí, které operuje s jazykovým kódem rozvinutým. $V$ mnoha prípadech česky nerozumí tak, aby bylo schopné zvládat výuku. Odborníci volají již delší dobu po zavedení bilingvních asistentů pedagoga, ještě lépe po romsky mluvících pedagozích, a nejlépe po romských učitelích. Uvědomění si existence a významu jazykových kódů pro vzdělání by mohlo mít za následek, že bychom byli více tolerantnější a edukační proces by byl efektivnější.

\section{Prorůstové nastavení mysli}

Často jsme u dotazovaných romských dětí zaznamenali zřejmou rezignaci na budoucnost a absenci dlouhodobého plánování. Proč bych se měl snažit, když stejně nebudu mít práci? Proč bych měla studovat, když to nikdo neocení? Stejně se na mě budou ostatní dívat divně. Nic s tím nenadělám. Co bude, mě nezajímá, at' si alespoň užiji současnost. Jsem Rom, nemám šanci. Podobná vyjádření jsme zaznamenali i u bývalých chovanců. Zde by mohl pomoci přístup prorůstového nastavení mysli. Ten tvrdí, že je chybou se zaměřovat na věci nám dané a na pouhé výsledky. Což dítěti bere pocit, že dosáhlo výsledků samo a utvrzuje jej v přesvědčení, že za jeho výsledky je odpovědný jím neovlivnitelný faktor. Mnohem větší efekt má podpora snahy dítěte a jeho aktivní práce k výsledkům vedoucí (Dweck, 2000). Toto můžeme aplikovat i na problematiku vzdělávání Romů. Zaměřujeme se na silné stránky, nenecháme se limitovat slabinami.

\section{Feuersteinovo instrumentální obohacování}

Další z moderních metod, které získávají na popularitě je Feuersteinova teorie instrumentálního obohacování. Feuerstein studoval, proč některé děti ve škole podávají výkony prokazatelně horší, než jsou jejich schopnosti. Vypracoval komplexní přístup, který je zaměřen na maximalizace schopností jedince za pomoci celkové kognitivní změny od pasivního stylu k aktivnímu a nezávislému studentovi (Feuerstein, 2014, s. 24). Jako základ vidí poskytnutí prostředků pro úspěšnou adaptaci jedince na jeho jedinečné prostředí. Podle Feuersteina je možné aktivizovat naprostou většinu studentů. Pokud bychom tento prístup aplikovali na romské děti v Dětském domově Klánovice, museli bychom nejprve přehodnotit náš současný přístup, kdy předpokládáme, že naše představy o vzdělání jsou i představami vzdělávaných. Měli bychom si uvědomit, že každé dítě má svoji silnou stránku, na které Ize postavit základy úspěchu v dalších oblastech (Armstrong, 2009, s. 69). Pokud by děti byly aktivními součástmi edukačního procesu, měly by šanci si ke vzdělání vybudovat pozitivní vztah.

\section{Závěr}

Jak jsme již zmínili, tato práce si kladla za cíl být sondou do života dětí romského původu v Dětském domově Klánovice. Neaspirovali jsme na nová zjištění v oblasti vzdělávání Romů, snažili jsme se jen podělit o zkušenosti z praxe, nabídnout inspiraci a poukázat na nové přístupy ve vzdělávání Romů. Hlavním výstupem, který vyplynul ze získaných informací je skutečnost, že se romské děti v dnešní společnosti setkávají s řadou výzev. 
Neustále přetrvává nedůvěra spojená s předsudky, kterou bychom mohli nazvat diskriminací. Ptejme se, máme všichni rovné přiležitosti? Je současný systém vzdělávání připraven udělat krok vpřed a otevř́t se opravdu každému? Nebo budeme setrvávat v edukační realitě, které je funkční pouze pro bezproblémové a standardizované děti? Inkluze by měla být chápána jako důležitá hodnota vzdělávacího systému (Norwich, 2005, s.56). Můžeme tvrdit, že proces inkluze je možný především ve společnosti, jejíž podstata je demokratická (Nilholm, 2006, s. 442). Jsme demokratičtí? Ptejme se, proč by statisíce našich romských spoluobčanů měly být odsouzeny k chudobě, protože bez vzdělání na ně čeká pouze nekvalifikovaná a nárazová práce (European Union \& Agency for Fundamental Rights, 2016, s. 10). Zde, ve vzdělání, hledejme řešení. Podle našeho názoru jediná možnost, jak změnit tuto nepř́znivou situaci, je umožnit všem Romům kvalitní vzdělání. Je třeba pomoci Romům vybudovat vrstvu inteligence, aby měli možnost pozitivních vzorových modelů. Mnozí zpochybňují schopnosti Romů, dokonce i samotní Romové. S tímto naprosto nesouhlasíme a jsme přesvědčeni, že Romové jsou schopni uspět $v$ jakékoli společenské oblasti. Pojd'me umožnit Romům se realizovat $v$ naší společnosti. Bud'me si vědomi romství a jeho sociokulturních specifik, nicméně toto nechápejme jako negativní determinantu, ale jako faktor pozitivního rưstu. Snažme se romské děti nasměrovat do budoucnosti a naučme je, že jsou odpovědné za svoje životy. Právě přenesení odpovědnosti na Romy samotné bude bezesporu velkou výzvou pro celou naši společnost. Bude to dlouhodobý proces, ale pevně věříme, že $v$ budoucnosti se naši pravnuci se budou budit do společnosti, kde nebude jinakost chápána jako problém, ale bude normou. Vždyt' toto je vlastně definice tak často diskutované inkluze. Není cílem moderní a progresivní edukační reality produkovat stáda identických jedinců, naším snažením budiž prostředí, kde opravdu každý bude moci uplatnit své jedinečné vlastnosti. Vidíme zde velkou výzvu a smysluplný cíl. Společně napněme síly a vytrvejme!

\section{Poděkování}

Uprímné poděkování patří paní docentce Evě Šotolové. Nejen za cenné podněty při konzultacích nad tématem našeho výzkumu, ale především za její angažovanost na poli edukace Romů.

\section{Literatura}

Armstrong, T. (2009). Multiple intelligences in the classroom (3rd ed.). Alexandria, Va: Association for Supervision and Curriculum Development.

Bernstein, B. B. (2003). Class, codes, and control. London; New York: Routledge.

Roma children. Children's Rights. Dostupné z: https://www.coe.int/en/web/children/rom a-children

Daněk, A. (2019). Specifika vzdělávacího procesu v prostředí Dětského domova Klánovice. In: Inovativní prístupy $k$ edukaci osob se speciálními potřebami. Ostrava: Ostravská univerzita.

Dweck, C. S. (2000). Self-theories: their role in motivation, personality, and development: their role in motivation, personality, and development. Philadelphia, Pa: Psychology Press.

Česko, (2002). Zákon č. 109/2002 Sb. o výkonu ústavní výchovy nebo ochranné výchovy ve školských zařízeních a o preventivně výchovné péči ve školských zařízeních a o změně dalších zákonů

Council of Europe. (2020). Roma children. Dostupné z: https://www.coe.int/en/web/child ren/roma-children

European Union \& Agency for Fundamental Rights (2016). Chudoba a zaměstnanost: situace Romů v jedenácti členských státech EU: průzkum romské populace: zaměřeno na údaje.: situace Romů v jedenácti členských státech EU. Luxembourg: Publications 
Office. Dostupné z: http://bookshop.europa.eu/uri?target=EUB:NOTICE:TK0113754:CS :HTML

Feuerstein, R. (2014). Vytváření a zvyšování kognitivní modifikovatelnosti: Feuersteinův program instrumentálního obohaceni: Feuersteinưv program instrumentálního obohacení. Praha: Karolinum.

Hanzal, J. (2004). Cikáni na Moravě v 15. až 18. století: dějiny etnika na okraji společnosti: dějiny etnika na okraji společnosti. Praha: Nakl. Lidové noviny.

Janský, P. (2014). Dítě s problémovým chováním a náhradní výchovná péče ve školských zařízeních pro výkon ústavní a ochranné výchovy. Recenzované monografie. Hradec Králové: Gaudeamus.

Katz, J. H. (1978). White awareness: handbook for anti-racism training: handbook for anti-racism training. Norman, Okla: University of Oklahoma Press.

Lacková, E. \& Hübschmannová, M. (2010). Narodila jsem se pod št’astnou hvězdou. Matějček, Z. (2005). Výbor z díla. Praha: Karolinum.

Nečas, C. (2002). Romové v České republice včera a dnes (5. dopl. vyd.). Olomouc: Univerzita Palackého.

Nilholm, C. (2006). Special education, inclusion and democracy. European Journal of Special Needs Education, 21(4), 431-

445. Dostupné z: https://doi.org/10.1080/08856250600957905

Norwich, B. (2005). Inclusion: Is it a matter of evidence about what works or about values and rights? Is it a matter of evidence about what works or about values and rights? Education 3-13, 33(1), 51-

56. Dostupné z: http://www.tandfonline.com/doi/abs/10.1080/03004270585200091

Škoviera, A. (2007). Dilemata náhradní výchovy: [teorie a praxe výchovné péče o děti v rodině a $v$ dětských domovech]: [teorie a praxe výchovné péče o děti $v$ rodině a $v$ dětských domovech]. Praha: Portál.

Šotolová, E. (2011). Vzdělávání Romů. Praha: Karolinum.

Train, A. (2001). Nejčastější poruchy chování dětí: jak je rozpoznat a kdy se obrátit na odborníka. Praha: Portál.

Ústav školských informací. (1975). Mimoškolní zařizení: a/ družiny a kluby mládeže, b/ domy pionýrů a mládeže a stanice, c/ dětské diagnostické ústavy, dětské domovy a dětské výchovné ústavy. Praha: Ústav školských informací.

\section{Adresa autora}

PhDr. Alois Daněk, Ph.D.

Katedra speciální pedagogiky, Pedagogická fakulta, UK v Prahe

Magdalény Rettigové 4, 11639 Praha 1

danek@ddklanovice.cz 


\title{
ANALÝZA STAVU A PROBLÉMOV PEDAGÓGOV PRI PREPÁJANÍ TEÓRIE A PRAXE VÝCHOVY A VZDELÁVANIA V SÚČASNOSTI SO ZAMERANÍM NA APLIKOVANIE METODIKY ESP NA HODINÁCH ANGLICKÉHO JAZYKA NA STREDNÝCH ODBORNÝCH ŠKOLÁCH
}

\section{ANALYSIS OF THE STATE AND PROBLEMS OF TEACHERS IN CONNECTING THE THEORY AND PRACTICE OF EDUCATION AND TRAINING AT PRESENT WITH A FOCUS ON THE APPLICATION OF THE ESP METHODOLOGY IN ENGLISH LANGUAGE LESSONS IN SECONDARY VOCATIONAL SCHOOLS}

Janka Mil'anová

Stredná odborná škola obchodu a služieb, Martin

\begin{abstract}
:
The world we live in is characterized by a high degree of globalization, this fact has an impact on all spheres of our lives. The interconnection of individual areas of life is also reflected in the teaching of foreign languages and in the increased demands on teachers. The teacher still remains a mediator of foreign language competence at different language levels and for different needs of students. However, communicative approaches in the teaching of target languages have changed the concept of traditional professional language teaching. The perception of language as a means of communication enabled the creation of a new concept called English for Specific Purposes (ESP). As this concept of teaching is more complete than traditional approach to teaching, there is a need of change. It is well known that the success of foreign language teaching depends directly on the learner, but also on the teacher and the text which the student is working with. Theoretical teaching material (textbooks, worksheets) is a starting source of information for us. The professional teaching material, which is intended for teaching through the ESP concept, is highly authentic, which makes it attractive and usable for students of individual fields of study in their professional careers. Teaching through the ESP concept in Slovakia is implemented mainly at universities. Given the aforementioned globalization and openness to the foreign labor market there is a need to apply the ESP concept in secondary vocational schools, which has the potential to send into practice professionally and linguistically prepared, highly qualified professionals at the international level.
\end{abstract}

Key words:

ESP, communicative approach, vocational training material, secondary vocational schools

\section{Úvod}

Jazyk je komunikačný prostriedok a komunikácia je aj najvyšším ciel’om pri výučbe anglického jazyka na všetkých stupňoch vzdelania. Rozvoj kompetencií v anglickom jazyku a komunikácia podporujú mobilitu v rámci štátov Európskej únie (EÚ) a umožňujú 
jej občanom pracovat' a študovat' v niektorom z jej členských štátov (Gadušová, Z. 2009, s. 4). Anglický jazyk sa stal jazykom Lingua franca, teda používa sa na celom svete ako jazyk globálny, čím plní funkciu internacionálneho dorozumievacieho prostriedku (Barnau, A. 2014/2015, s. 25).

Povinná výučba anglického jazyka na Slovensku od 3.ročníka ZŠ začala v školskom roku 2011/2012. Od školského roku 2019/2020 došlo k zmene, podl'a ktorej rodičia majú možnost' vol'by prvého cudzieho jazyka v 3. ročníku. Napriek takejto úprave, väčšina slovenských škôl zostala pri starom, zaužívanom systéme výučby anglického jazyka ako prvého jazyka. Druhý jazyk si žiaci a ich rodičia vyberajú z ponuky na škole, kde študujú. Vo väčšine prípadov sa jedná o nemecký jazyk a ruský jazyk.

Príchodom na strednú školu žiaci pokračujú v štúdiu cudzích jazykov. Maturitné odbory ponúkajú možnost' štúdia aspoň dvoch cudzích jazykov. V tomto prípade si žiaci vyberajú jazyk, z ktorého budú maturovat'. Maturita z cudzích jazykov je na stredných školách povinná na úrovni B1, žiaci si môžu zvolit' vyššiu úroveň B2. Na gymnáziách žiaci povinne maturujú z cudzieho jazyka na úrovni B2, na bilingválnych stredných školách maturujú povinne na úrovni $\mathrm{C} 1$.

Príchodom na vysokú školu, štúdium cudzích jazykov ostáva, zmena nastáva pri obsahovej zložke predmetu, t.j. vysoké školy (nefilologického zamerania) sa zameriavajú na výučbu odborného cudzieho jazyka (dominantne sa jedná o anglický jazyk). Odborná angličtina, alebo inak povedané - Angličtina pre špecifické účely - ESP (English for Specific Purposes) sa sústred'uje na jazykovú kompetenciu tých, ktorí cudzí jazyk aplikujú pre svoje účely v odbornom sektore.

Ciel'om každého učitel'a je úspešné prepojenie teórie a praxe. K naplneniu spomínaného ciel'a napomáha zvolenie vhodnej metodiky, adekvátnych študijných materiálov, či audiovizuálnych pomôcok. Je v kompetencii pedagóga zvolit' práve takú metódu, ktorá žiakov motivuje $\mathrm{k}$ učeniu a nesie $\mathrm{v}$ sebe potenciál zvýšenia efektivity výchovnovzdelávacieho procesu.

Koncept ESP nám ukazuje nový smer výučby, ktorý by s vel'kou pravdepodobnostou mohol byt' aplikovaný aj na slovenských stredných odborných školách. Predstavoval by odklon od zaužívaného spôsobu vyučovania, vítanú zmenu, ktorá nesie v sebe pridanú hodnotu a je atraktívna pre učitel'a aj samotného žiaka. Samotná výučba odborných cudzích jazykov a jej interkultúrne smerovanie zabezpečuje jej komplexnost' a efektívnejšie využívanie $v$ medzinárodnom kontexte. Je vel'mi pravdepodobné, že odborný cudzí jazyk vyučovaný už na strednej škole prispeje k získaniu vedomostného bonusu, ktorý absolventom pomôže bezproblémovo fungovat' $v$ medzinárodnom študijnom a pracovnom prostredí.

\section{Nové prístupy k vyučovaniu Anglického jazyka}

Anglický jazyk je už dlhodobo uznávaným medzinárodným komunikačným prostriedkom vd’aka ktorému si odborníci z celého sveta dokážu vymieňat' odborné poznatky, otvára bránu lepším pracovným možnostiam, žiakom umožňuje absolvovat' svoje štúdium, resp. stáž na zahraničnej akademickej pôde. Jazyk je komunikačný prostriedok a komunikačná kompetencia je aj najvyšším ciel'om pri výučbe anglického jazyka na všetkých stupňoch vzdelania (Gadušová, Z. 2009, s. 4).

K najvýraznejším problémom pri výučbe anglického jazyka patrí najmä strach z komunikácie, pretože sa študenti obávajú urobit' chybu (vo výslovnosti, alebo z neznalosti vhodných výrazov) a z toho vyplýva aj pasivita študentov na prednáškach a cvičeniach. Úzkost' a strach spojené s cudzím jazykom dokážu ovplyvnit' vzdelávacie výsledky (Lojová, G., Vlčková, K. 2011, s. 141).

Kompetencie žiakov $v$ cudzom jazyku sa rozvíjajú efektívnejšie, ked' majú poznatky o učebných štýloch, pretože každému z nás vyhovuje iný štýl učenia sa. „Učebný štýl je súhrn postupov, ktoré jednotlivec v určitom období preferuje pri učeni“" (Turek, I. 2005, s. 
85). Pre žiaka, rovnako aj pre učitel'a je dôležité vediet', aký učebný štýl jednotliví študenti preferujú. Vol'ba vhodného učebného štýlu sa prejaví vo vyššej miere efektívnosti učenia sa. Podla zmyslového vnímania učebné štýly delíme na: vizuálny (visual), auditívny (auditory), verbálny (reading) and pohybový (kinesthetic). Na zistenie jednotlivých preferencií v učebných štýloch sa používa dotazník, nazývaný VARK. Pre každý zo spomenutých štýlov sú vhodné iné cvičenia a aktivity.

$\checkmark$ priebehu dvoch minulých storočí sa striedali názory na optimálne metódy výučby cudzích jazykov. Bádatelia sa snažili nájst' ten najsprávnejší opis na vyjadrenie vzt'ahu medzi teóriou a praxou. Podla Browna (Brown, D.H. 2000, s. 16) vyučovacia metóda predstavuje: „všeobecný súbor presných popisov v triede pre dosiahnutie lingvistických ciel'ov. Metódy majú tendenciu zaoberat' sa primárne úlohami a správaním vyučujúceho a študenta a druhotne lingvistickými a predmetovými ciel'mi, postupnost'ou a materiálmi.“ Vo výučbe anglického jazyka sú známe tieto metódy: gramaticko-prekladová, priama, audio-lingválna, komunikatívna a tzv. TPR metóda (Total Physical Response) (Barnau, A., Džuganová, B. 2020, s. 13).

V 90-tych rokoch minulého storočia sa vo výučbe cudzích jazykov začal klást' dôraz na komunikatívnu metódu (Communicative Language Teaching). Popri gramatických kategóriách a slovnej zásobe sa v tejto metóde kladie dôraz na čiastkové kompetencie akými sú, lingvistická, sociolingvistická, kultúrna, strategická, funkčná a diskurzná kompetencia (Brown, D. H. 2000, s. 42-44). Z toho vyplýva, že učebný proces aj kritériá hodnotenia ústneho prejavu žiakov by mali mat' za základ práve tieto požiadavky a do vyučovacieho procesu by sa mali zaradit' tie aktivity, ktoré umožnia žiakom získat' spomenuté kompetencie.

V komunikatívnej metóde sa dostali do popredia dva princípy - princíp situačnosti a autentickosti, teda schopnost' rozprávat' v konkrétnych reálnych situáciách, kde vyučujúci tvorí podmienky pre autentickú komunikáciu a interakciu medzi žiakmi v triede a opravuje len tie lingvistické chyby, ktoré spôsobujú zlyhanie komunikačného procesu (Barnau, A., Džuganová, B., 2020, s. 14). Vyučujúci plní organizačnú, kontrolnú a poradnú funkciu, pričom študenti sú aktívni a nie pasívni príjemcovia vedomostí.

Vyučovacie predmety prvý cudzí jazyk a druhý cudzí jazyk patria medzi všeobecnovzdelávacie predmety a sú súčast'ou vzdelávacej oblasti Jazyk a komunikácia (ŠPú, ISCED 2, 2020). Táto vzdelávacia oblast' je zameraná na postupné osvojovanie si jazyka, ktorý sa chápe ako nástroj myslenia, komunikácie a zdroj osobného a kultúrneho obohatenia človeka. Dôraz sa kladie na praktické využitie osvojených kompetencií, efektívnu komunikáciu, uvedomenie si a rešpektovanie kultúrnej a jazykovej rôznorodosti. Spolu s komunikačnými jazykovými kompetenciami sa rozvíjajú i všeobecné kompetencie, čo poskytuje priestor pre uplatnenie medzipredmetových vzt'ahov (ŠPú, ISCED 3, 2020).

V predmetoch prvý cudzí jazyk a druhý cudzí jazyk sa rozvíjajú všeobecné a komunikačné jazykové kompetencie $v$ súlade so Spoločným európskym referenčným rámcom pre jazyky (SERR). Spoločný názov pre úrovne B1 a B2 je samostatný používatel' (independent user), čo predpokladá, že žiak aktívne pristupuje k získavaniu vedomostí nielen na hodinách anglického jazyka, ale i prostredníctvom všetkých dostupných médií (samoštúdiom) v zhode so svojimi osobnými záujmami a profesijnou orientáciou (SERR, 2017, s. 27). Požiadavky kladené na žiaka predpokladajú uvedomelý prístup žiaka k osvojeniu si cudzieho jazyka.

\section{ESP a vyučovanie Anglického jazyka v odbornom vzdelávaní na Slovensku}

Komunikatívne prístupy vo výučbe cudzích jazykov zmenili koncept tradičného vyučovania odborného jazyka. Vnímanie jazyka ako prostriedku komunikácie umožnilo vytvorenie nového konceptu pod názvom Angličtina pre špecifické účely ESP (English 
for Specific Purposes) (Athanasiou, A., et al. 2016, s. 298). Tento koncept sa sústred'uje na jazykovú kompetenciu tých, ktorí ho aplikujú pre svoje účely v odbore, v ktorom pracujú.

Ovládanie minimálne jedného cudzieho jazyka $v$ dnešnom globalizovanom svete je nevyhnutné. Na trhu práce sa často stretávame dokonca s požiadavkou na uchádzačov o zamestnanie, aby ovládali dokonca dva alebo aj viac cudzích jazykov. Od roku 1990 došlo k zmenám a zlepšeniu situácie v jazykovom vzdelávaní. Vstupom Slovenskej Republiky do Európskej únie po roku 2004, sa otvoril nový pracovný trh, otvorili sa možností pre študentov študovat' v členských krajinách EU, resp. zúčastňovat' sa odborných stáží. Zmeny nastali aj v prístupe $\mathrm{k}$ výučbe a vzdelávaniu, učitelia si mohli zvyšovat' kvalifikáciu a doplňovat' svoje vzdelanie doma a v zahraničí, narastali možnosti prepájania vyučovania cudzieho jazyka s modernými technológiami, audiovizuálnymi pomôckami, online priestor priniesol širokú paletu podnetných výučbových materiálov. Pedagógovia v rámci programov celoživotného vzdelávania si priebežne rozširujú svoje vzdelanie, nadobúdajú nové zručnosti v používaní moderných technológií, ktoré sú pre učitel'a zdrojom najnovších poznatkov, sú nástrojom modernej komunikácie ako aj bránou k novým vedomostiam. Okrem elektronických zdrojov, zmena nastala aj v ponuke cudzojazyčnej literatúry a učebníc. „Zmenila sa ponuka jazykových učebníc a kurzov, učitelia dostali možnost' efektívne si zvyšovat' kvalifikáciu, skvalitnit' svoje jazykové a metodické kompetencie a pracovat' podl'a nových osnov“ (Čuriová, H. 2020, s. 31).

Angličtina pre špecifické účely (ESP) vznikla pre potreby profesionálneho využívania cudzieho jazyka. Svoje opodstatnenie nachádza v nespočetnom množstve profesií, ktoré so sebou viažu špecifickú slovnú zásobu ako aj komunikačné situácie. Obchodná angličtina pomôže $\mathrm{k}$ úspechom $v$ obchodnom podnikaní. Existuje napr. Angličtina pre lekárov, čašníkov, pracovníkov v IT sfére a pod.

Pavlíčková (2015) uvádza, že absolvent strednej školy, ktorý chce študovat' na univerzite v anglicky hovoriacej krajine, potrebuje angličtinu, aby bol schopný plnit' požiadavky vysokoškolského štúdia, písal eseje, aby sa mohol aktívne zúčastňovat' seminárov. V jeho prípade ide o angličtinu pre akademické účely (EAP - English for Academic Purposes). Študent technickej univerzity alebo medicíny, potrebuje takú znalost' angličtiny, ktorá by mu umožnila čítat' články o predmete svojho štúdia, t. j. angličtinu pre účely vedy a techniky (EST -English for Science and Technology Potreby $v$ cudzojazyčnom vyučovaní označujeme ako angličtina pre potreby výkonu zamestnania (EOP -English for Occupational Purposes). Tieto názvy vznikli preto, aby pomenovali rôzne oblasti vyučovania angličtiny. Každá vznikla na základe iných potrieb, z iných ciel'ov učiaceho sa.

Hutchinson a Waters charaterizujú metodiky ESP nasledovne (Hutchinson, T., Waters, A. 1987, s. 8): angličtinu potrebnú pre konkrétnu skupinu žiakov je možné identifikovat' analýzou jazykových charakteristík ich špecializovanej oblasti práce, alebo štúdia. Hlavným princípom ESP sa stalo „Povedz mi, na čo potrebuješ angličtinu a ja ti poviem angličtinu, ktorú potrebuješ“.

„ESP učitel' a študent plnia v procese vyučovania a učenia rôzne úlohy, avšak ich ciele sú rovnaké. ESP učitel' nie je odborníkom v odbore, ktorého študentov vyučuje, ale vo vyučovaní angličtiny“ (Čuriová, H. 2020, s. 32). Na základe spomenutého môžeme potvrdit', že komunikácia s odborníkmi z praxe (v prípade odborného školstva sa jedná o majstrov odborného výcviku, učitel'ov odborných predmetov, resp. aj profesionálov z praxe) je vel'mi dôležitá. Odborne skonzultované a skontrolované učebné materiály nám zaistia to, že učebné texty a audiovizuálne pomôcky budú relevantné a autentické. Z praxe môžeme potvrdit', že práca $s$ autentickými materiálmi, ktoré prepájajú prvky odboru, ktorý daní žiaci študujú, s Anglickým jazykom, majú pre žiakov výrazne motivačný charakter. 
Tvorba ESP materiálov nie je jednoduchá, vyžaduje vel'a času, tvorivosti a trpezlivosti. Učitel' musí mat' na zreteli $v$ prvom rade žiaka a jeho odborné vzdelávacie potreby. Nakol'ko učitel' Anglického jazyka, nemusí byt' aj profesionálom v odbore, ktorý daný žiak študuje, konzultácia pri tvorbe výučbových materiálov s odborníkmi z praxe je, ako sme už spomenuli, klúčová.

„Vyučujúcim predmetom je angličtina, nie profesia v angličtine. Žiaci ovládajú predmet lepšie ako učitel', ich vzdelávanie je nasmerované na špecifický odbor a svoju výučbu angličtiny chápu ako dopInenie tohto odborného vzdelávania. Učitel' im poskytuje pomoc, rozvíja ich jazykové znalosti, prináša do výučby potrebné nástroje, metódy a koncepcie, poskytuje spätnú väzbu“ (Khoirunnisa, K., et al. 2018, s. 38).

Tomlinson ponúka niekol'ko kritérií na ohodnotenie učebných materiálov (Tomlinson, B. 2013, s. 21): prít’ažlivost' a vierohodnost' materiálov pre žiakov a učitel'ov; validita materiálov; reliabilita materiálov (t. j. mali by rovnaký účinok v rôznych skupinách žiakov); schopnost' materiálov zaujat' žiakov a učitel'ov; schopnost' materiálov motivovat' žiakov; hodnota materiálov z hl'adiska krátkodobého vzdelávania (dôležité napríklad pre vykonanie skúšok); hodnota materiálov z hl'adiska dlhodobého štúdia (komunikačných schopností); percepcia materiálov žiakmi; percepcia materiálov učitel'mi; pomoc poskytovaná učitel'om, pokial' ide o prípravu, odučenie a hodnotenie; flexibilita materiálov (napr. do akej miery učitel' l'ahko prispôsobí materiály konkrétnemu kontextu); príspevok materiálov k rozvoju učitel'ov; zhoda s výučbovými požiadavkami (napr. použitie aj v iných triedach, pokrytie učebných osnov, príprava na skúšku).

Výučba prostredníctvom konceptu ESP sa zameriava na odbor a hlavným ciel'om je pripravit' absolventov daného odboru na bezproblémové fungovanie $v$ praxi, t.j. $v$ pracovnom prostredí v domácej krajine ako aj v zahraničí. Umožňuje žiakom pokračovat' v štúdiu na zahraničných školách a otvára im aj nové možnosti z hl'adiska výmeny odborných vedomostí a zručností so zahraničným odborníkmi prostredníctvom odborných stáží.

Schneiderová a Zelenková, ktoré sa venujú problematike ESP na pôde vysokých škôl, opisujú svoje stanovisko nasledovne (Schneiderová, A., Zelenková, A. 2016, s. 2): „Veríme, že vedomosti študentov o ich súčasných a budúcich potrebách im umožňujú zmysluplne študovat', môžu ich motivovat' k dosiahnutiu vyššej úrovne znalosti angličtiny a viest' $\mathrm{k}$ ich lepšiemu umiestneniu na budúcom trhu práce."

Európska únia sprístupnila mobility Erasmus+ aj pre žiakov stredných odborných škôl, vd'aka ktorým sú žiaci motivovaní cestovat' do zahraničia s ciel'om zvyšovat' jazykové a odborné kompetencie Od roku 2014 žiaci našej školy pravidelne participujú na spomínaných odborných stážach $\mathrm{v}$ zahraničí. Podmienkou účasti na spomenutom programe je pre žiakov odborných škôl znalost' anglického, resp. iného cudzieho jazyka. Táto skutočnost' preveruje pripravenost' žiakov a úroveň ich komunikačných zručností v cudzom jazyku. Upriamenie pozornosti na komunikatívne kompetencie žiakov je preto vel'mi dôležité. Mnohí absolventi odbornej stáže po návrate zo zahraničia vyhodnocujú svoje komunikačné zručnosti za postačujúce, ale na druhej strane im chýbala odborná, špecifická terminológia, prípadne aj frázy v odbornej komunikácii.

Mobility Erasmus+ poodhalili štrbiny a nedostatky $v$ tradičnej výučbe a nastolili potrebu zmeny vo vyučovaní so zameraním na odbornú terminológiu u našich žiakov a boli hybnou silou $v$ experimentálnom overovaní aplikácie metodiky ESP na našej škole. Jedná sa o vybrané odbory gastronomického zamerania - študijný odbor Hotelová akadémia a Kuchár - Čašník. Výučba prostredníctvom metodiky ESP prináša na hodiny anglického jazyka aktivity, ktoré sú spojené s odborom, ktorý žiaci študujú, majú pre nich praktické opodstatnenie a tým sú pre nich zaujímavé a motivujúce. Napriek tomu, že implementácia metodiky ESP v slovenských podmienkach nie je jednoduchá, kladná odozva zo strany žiakov, ich nadšenie, motivácia, ako aj zlepšenie ich študijných 
výsledkov potvrdzuje jej opodstatnenost'. Veríme tomu, že záujem žiakov a rodičov by mohol byt' hybnou silou a motiváciou k postupnému využívaniu metodiky ESP na všetkých stredných odborných školách. Kladné výsledky žiakov, radost' z učenia, ako aj l'ahšie uplatnenie absolventov na medzinárodnom trhu práce by boli vítanou odmenou. ESP predstavuje vyučovanie odbornej angličtiny, jej osvojovanie sa vel'mi rýchlo rozširuje a kladie si za ciel' rozvíjat' nielen akademické zručnosti, ale aj sociálne a interkultúrne kompetencie. Vzhl'adom na všetky spomínané skutočnosti by bolo viac ako vítané, aby si koncept ESP našiel svoje domovské miesto na všetkých slovenských stredných odborných školách.

\section{Záver}

V 21. storočí je zlepšovanie cudzojazyčných kompetencií samozrejmost'ou. Spoločnost' je vo vysokej miere charakterizovaná interkulturalitou, flexibilitou a samozrejme aj globalizáciou. Európska únia sprístupnila mobility Erasmus+ aj pre žiakov stredných odborných škôl, vd'aka ktorým sú žiaci motivovaní cestovat' do zahraničia s ciel'om zvyšovat' jazykové a odborné kompetencie.

Výučba ESP na stredných odborných školách, by mala priniest' na hodiny angličtiny aktivity, ktoré sú spojené s odborom, ktorý žiaci študujú, majú pre nich praktické opodstatnenie a tým sú pre nich motivujúce.

Implementácia konceptu ESP v slovenských podmienkach má svoje opodstatnenie, ale nie je jednoduchá. Veríme tomu, že záujem žiakov a rodičov by mohol byt' hybnou silou a motiváciou k postupným zmenám. Kladné výsledky žiakov, radost' z učenia by boli vítanou odmenou.

Koncept ESP ponúka inovatívny spôsob osvojovania si cudzieho jazyka, podporuje rozvoj medzi predmetových vzt'ahov a ponúka pre prax odborníkov, ktorí sa vo svete nestratia. Mobility $v$ rámci krajín EÚ, bohaté študijné a pracovné príležitosti $v$ rámci globálneho sveta predstavujú vynikajúcu motiváciu k zvýšenému záujmu pre učenie sa odbornej angličtiny.

\section{Literatúra}

ATHANASIOU, A. CONSTANTINOU, E. K., NEOPHYTOU, M., NICOLAOU, A., SOPHOCLEOUS, S. P., YEROU, C., 2016. Aligning ESP courses with the Common European Framework of Reference for Languages. CercleS, 6(2): 297-316. DOI 10.1515/cercles-2016-0015

BARNAU, A. 2014/2015. Vizuálna podpora ako motivačný faktor vo výučbe angličtiny u študentov ošetrovatel'stva. In: Cizí jazyky. Roč. 58, č. 5, 2014/2015, s. 25-37. ISSN 1210-0811.

BARNAU, A, DŽUGANOVÁ, B., 2020. English for Health Care Professionals. Hamburg: Verlag Dr. Kovač, 140 s. ISBN 978-3-339-11500-3.

BROWN, D. H., 2000. Teaching by Principles: An Interactive Approach to Language Pedagogy. White Plains, NY: Pearson Education. ISBN-0-13-028283-9.

ČURIOVÁ, H., 2016. Úlohy učitela a študentov vo vyučovaní ESP. In: Klúčové kompetencie pre celoživotné vzdelávanie $\mathrm{V}$ [elektronický zdroj]: zborník príspevkov Centra celoživotného a kompetenčného vzdelávania Prešovskej univerzity v Prešove. Prešov: Prešovská univerzita v Prešove. ISBN 978-80-555-1727-8. [CIT. 2020-05-29] Dostupné na internete: https://www.pulib.sk/web/kniznica/elpub/dokument/Gogova1/subor/Curiova.pdf GADUŠOVÁ, Z., BENČíKOVÁ, E., ORMISOVÁ, M., VAŠŠOVÁ, V. 2009. Pedagogická dokumentácia z anglického jazyka: Úroveň A2. Bratislava: ŠPÚ. ISBN 978-80-89225-774. [CIT. 2020-05-29] Dostupné na internete: http://www.educj.sk/buxus/docs/AJ-A2.pdf 
HUTCHINSON T., WATERS A., 1987. English for Specific Purposes: A Learning-centred Approach. Cambridge: Cambridge University Press, 183 s. ISBN 0521267323.

KHOIRUNNISA, K., SUPARNO, S., SUPRIYADI, S. 2018. ESP Teacher's and Students' Perceptions on Teaching Speaking for a Tourism Program. In: Dinamika IImu 18 (1): 3748. [CIT. 2020-05-29] Dostupné na internete: https://journal.iainsamarinda.ac.id/index.php/dinamika ilmu/article/view/945

LOJOVÁ, G., VLČKOVÁ, K., 2011. Styly a strategie učení ve výuce cizích jazyku. Praha: Portál, 141 s.. ISBN 978-80-7367-876-0.

PAVLÍČKOVÁ, E. 2015. Tvorivost' v škole - škola tvorivosti: 3. online konferencia 28.29.9.2015. [CIT. 2020-05-29] Dostupné na internete. https://www.pulib.sk/web/kniznica/elpub/dokument/Germuskova3/subor/Pavlickova.pdf SCHNEIDEROVÁ, A., ZELENKOVÁ, A., 2016. Motivation to use foreign language competence on the international labour market. In: Economics and legal issues and challenges of the labour market and individual well-being - Ekonomicko-právne problémy a výzvy trhu práce a ich vplyv na blahobyt. Ed. Mária Uramová, Zdislaw Majkut, Michal Turošík. Banská Bystrica: Vydavatel'stvo Univerzity Mateja Bela - Belianum. ISBN 97880-557-1089-1. [CIT. 2020-05-29] Dostupné na internete: https://www.ef.umb.sk/konferencie/myto/articles/Schneiderova,Zelenkova.pdf SPOLOČNÝ ERÓPSKY REFERENČNÝ RÁMEC PRE JAZYKY. 2017. Bratislava: ŠPÚ. [CIT. 2020-05-29] Dostupné na internete. https://www.statpedu.sk/files/sk/publikacnacinnost/publikacie/serr tlac-indd.pdf

ŠTÁTNY PEDAGOGICKÝ ÚSTAV, 2020. ISCED 2: Jazyk a komunikácia. [CIT. 2020-0529] Dostupné na internete. ISCED 2 https://www.statpedu.sk/sk/svp/inovovany-statnyvzdelavaci-program/inovovany-svp-2.stupen-zs/jazyk-komunikacia/

ŠTÁTNY PEDAGOGICKÝ ÚSTAV, 2020. ISCED 3. [CIT. 2020-05-29] Dostupné na internete. https://www.statpedu.sk/sk/svp/statny-vzdelavaci-program/statny-vzdelavaciprogram-gymnazia/stupen-vzdelania/

TOMLINSON, B. 2013. Materials Evaluation. In: Developing Materials for Language Teaching. London: Bloomsbury, s. 21 - 48.

TUREK, I., 2005. Inovácie v didaktike, Bratislava: Metodicko-pedagogické centrum, 358 s. ISBN 8080522308.

\section{Adresa autora}

\section{Mgr. Janka Mil'anová}

Stredná odborná škola obchodu a služieb

Stavbárska 11, Martin 03680

jankamilanova@gmail.com 


\title{
KYBERŠIKANOVANIE AKO FORMA ONLINE RIZIKOVÉHO SPRÁVANIA A MOŽNOSTI JEHO PREVENCIE V ŠKOLÁCH
}

\section{CYBERBUILDING AS A FORM OF RISK BEHAVIOR ONLINE AND THE POSSIBILITY OF IT PREVENTION IN SCHOOLS}

\author{
Miriam Niklová \\ Katedra pedagogiky, Pedagogická fakulta, UMB v Banskej Bystrici \\ Karina Zošáková \\ Katedra pedagogiky, Pedagogická fakulta, UMB v Banskej Bystrici
}

\begin{abstract}
:
Electronic media with internet access are also becoming part of the lives of children and young people. Children are born into the digital world and are bound by technology from an early age. The lives of these "digital children" are formed by the intertwining of the really experienced and virtually "transferred" within cyberspace. In today's globalized society, the media are one of the greatest socializing factors in shaping a child's identity, values, attitudes, opinions and behaviors. At the same time, however, the question of the desocialization of the child's personality arises, who chooses one-sided mass media products uncritically, is not always able to choose between available content, within different social networks and can therefore be included in deviant groups. In the field of socio-pedagogical theory and practice, questions arise on how to use the greatest possible potential of the media in shaping the child's personality, but also on how to most effectively reduce the negative impacts on his development and acquired norms, values and patterns of behavior and socially undesirable behavior. The study pays attention to the risks of electronic media with regard to cyberbullying. At the same time, he points out the possibilities of how to effectively prevent cyberbullying in schools.
\end{abstract}

\section{Key words:}

risk behavior, youth, school, cyberbullying, prevention, school, social pedagogue

\section{Úvod}

Elektronické média sú v dnešnej dobe považované za neodmyslitel'nú súčast' života detí, mládeže, ale aj dospelých. Prenikajú do všetkých oblastí života a aj do školstva. Je nevyhnutné a vel'mi dôležité, aby boli využivané predovšetkým zmysluplne a citlivo a aby sa zabezpečil súlad medzi požiadavkami digitálneho sveta a potrebami jednotlivcov. Prudký rozvoj IKT prináša so sebou mnohé benefity, ale aj riziká, na ktoré je potrebné permanentne upozorňovat' (Barnová, Krásna, 2008).

Online rizikové správanie v kyberpriestore vníma mnoho autorov diferencovane. E. Poláková (2013, s.30) označuje rizikové správanie na internete nasledovne „používatelia zdiel'ajú na internete vel'a údajov a najmä na sociálnych siet’ach nemajú svoje súkromie dostatočne opatrené. Riskantným je ponechanie predvoleného nadstavenia súkromia na sociálnych siet'ach na „otvorené”. Niektorí používatelia, či už z neznalosti alebo z l'ahostajnosti, nechávajú svoje profily otvorené, a tým umožňujú vidiet' svoje súkromné dáta l'ud'om, ktorých nepoznajú. Prakticky robia z týchto údajov verejne dostupnú informáciu." M. Dulovics (2017) rizikové správanie na internete vníma ako správanie sa 
jednotlivca vo virtuálnom priestore, ktorý vedome alebo nevedome svojím správaním ohrozuje seba alebo svoje okolie. Dlhodobým fenoménom, ktorý sa vyskytuje v online priestore je kyberšikanovanie. Trlicová (2009) považuje kyberšikanovanie a zneužitie osobných údajov za najviac rizikové správanie, ktoré má vážne dôsledky na obete. Ked'že šikana je forma násilia páchaná na iných, môže sa prejavovat' pri osobnom kontakte. Súčasná doba vytvorila priaznivé podmienky šikanovania vo virtuálnom priestore. Šikanovanie ako závažný jav sa v kyberpriestore vyskytuje až 4x častejšie ako v reálnom prostredí. To potvrdzujú výskumy Šmahela (2003), ale aj Gregussovej a Kováčikovej (2008). Kyberšikanovanie sa odohráva vo virtuálnom priestore ktoré sa v mnohých atribútoch odlišuje od toho reálneho, rovnako ako sa tradišné šikanovanie diferencuje od kyberšikanovania.

\section{Kyberšikanovanie v kontexte empirických zistení v SR a ČR}

Kyberšikanovanie $v$ školskom prostredí z roka na rok naberá na intenzite. Dôkazom toho sú aj výskumy, ktoré boli realizované v oblasti kyberšikanovania na Slovensku, ale aj v Českej republike, kde obet’ami kyberšikanovania boli samotní žiaci, ale aj učitelia.

Na Slovensku realizovala K. Hollá (2015) rozsiahli empirický výskum prostredníctvom dotazníka. Výskumný súbor tvorilo 1619 respondentov - žiakov druhého stupňa základných škôl a 1. - 3. ročníka stredných škôl z celého Slovenska. Na základe výsledkov výskumu autorka dospela $\mathrm{k}$ záveru, že medzi najčastejšie formy kyberšikanovania u chlapcov patrilo zasielanie osočujúcich a hrubých urážok prostredníctvom internetu, čo označilo až 28,9\% opýtaných respondentov. Zasielanie klamlivých informácií o druhých označilo $24,3 \%$ opýtaných respondentov a zdielanie fotografií na internete, ktoré boli pre obet' kompromitujúce označilo 29,6\% z opýtaných respondentov. U dievčat prevažovali najmä formy ako uverejňovanie klamlivých informácií, čo označilo až $17,9 \%$, zasielanie správ a uverejňovanie komentárov s urážajúcim obsahom označilo 17,6 z opýtaných respondentiek, a uverejňovanie kompromitujúcich fotiek uviedlo $11,1 \%$ opýtaných respondentiek.

Ďalší z výskumov orientovaných na problematiku kyberšikanovania realizoval $v$ roku 2018 kolektív autorov P. Izrael, J. Holdoš, R. Ďurka a M. Hasák. Výskumný súbor tvorilo 969 detí a dospievajúcich používajúcich internet vo veku 9-17 rokov na Slovensku. Z výsledkov výskumu vyplynulo, že kyberšikanovanie sa najčastejšie uskutočňuje využívaním sociálnych sietí (81,4\%) a najmenej cez email (2,7\%). Agresori kyberšikanovania využívajú tiež správy cez mobilný telefón, čo uviedlo $21,3 \%$ respondentov. Výrazný rozdiel bol zaznamenaný vo využívaní sociálnych sietí pre účely kyberšikanovania u dievčat $(95,6 \%)$ oproti chlapcom $(64,7 \%)$. Kyberšikanovanie výhradne prostredníctvom sms správ cez mobilný telefón sa najčastejšie uskutočňuje vo veku 9-10 rokov. Zaujímavým je zistenie, že deti vo veku 11-12 uvádzajú kyberšikanovanie výhradne prostredníctvom sociálnych sietí, pričom používanie väčšiny sociálnych sietí je oficiálne povolené až od veku 13 rokov. Vo veku 13-17 rokov tiež výrazne prevládajú sociálne siete ako prostriedok na kyberšikanovanie. Z prezentovaných výsledkov výskumu sú obete najčastejšie vylúčené z nejakej skupiny alebo aktivity na internete (79\%), d’alej zverejňovaním nepríjemných informácií, ktoré sú zároveň dostupné respektíve zdiel'ané aj pre iných (79\%) ako aj vyhrážaním sa cez internet $(70 \%)$.

V roku 2020 prebiehal celoslovenský výskum na základných a stredných školách. Štatisticky bolo spracovaných 553 dotazníkov. Výskyt kyberšikanovania v školskom roku 2019/2020 bol zaznamenaný v 73,6\% skúmaných školách (Janková, 2020).

V roku 2016 bol realizovaný tiež výskum zameraný na kyberšikanovanie v Českej republike Centrom prevencie rizikovej virtuálnej komunikácie Pedagogickej fakulty Univerzity Palackého v Olomouci, ktorý podporovalo aj E-Bezpečí spoločnosti O2 Czech Republic. Ako výskumnú metódu použili online dotazníky a výskumnú vzorku tvorilo 5136 
respondentov. Výskumný súbor tvorili učitelia materských, základných, stredných aj vysokých škôl. Na základe zistení sa ukázalo, že až $21,73 \%$ z opýtaných učitel'ov sa už stalo obet'ou kyberšikanovania svojich žiakov. Najčastejšie sa kyberšikanovanie vyskytovalo $v$ podobe obt'ažovania prostredníctvom prezváňania na mobilný telefón učitel'a, vyhrážanie prostredníctvom mobilu alebo internetu, rozposielanie ponižujúcich a zosmiešňujúcich fotiek alebo zneužitie identity učitel'a. Podl'a výsledkov výskumu, najčastejšími kyberargresormi boli žiaci, s ktorými sú učitelia pravidelne v kontakte (Kopecký, Szotkowski, 2016).

\section{Prevencia kyberšikanovania}

S nárastom online rizikového správania, M. Dulovics (2012) zdôrazňuje význam mediálnej gramotnosti, ktorú je potrebné rozvíjat' u detí a mládeže. Autor (2012, s. 1516) konštatuje, že hoci je táto gramotnost' u súčasnej mladej generácii na vysokej úrovni, „...považujeme za nesmierne dôležité sústavné, komplexné, koordinované vzdelávanie detí a mládeže v oblasti informačných technológií prostredníctvom mediálnej výchovy. Tento spôsob vzdelávania je dôležitý predovšetkým z preventívneho aspektu, aby sa predišlo zneužívaniu moderných technológií, a aby sa poukázalo na ich pozitívne, plnohodnotné využívanie."

Deti a mládež patria na jednej strane k najpočetnejším a najaktívnejším užívatel'om elektronických médií, na strane druhej sú zároveň najrizikovejšou skupinou jednak vzhl'adom na to, že nedokážu vždy kriticky selektovat' informácie, ktoré im média ponúkajú a jednak preto, že virtuálne prostredie vytvára priestor pre vznik rizikového správania a špecifických sociálno-patologických javov. Toto potvrdzuje Niklová (2018) svojim výskumom, v ktorom autorka zistila, že s vekom žiakov sa ich názory na internet ako bezpečné prostredie menia, pričom starší žiaci si už uvedomujú a poznajú riziká, ktoré virtuálny svet prináša. Mladší žiaci si nie sú vedomí rizík, ktoré ku nim z virtuálneho prostredia prichádzajú, a práve preto je potrebné zamerat' sa na nich ako na najohrozenejšiu skupinu.

Tieto tvrdenia podporujú aj autori Graham a Metaxas (2003), ktorí svojou štúdiou dokázali, že žiaci považujú internet za primárny zdroj informácií, pričom mnohí majú problémy s rozpoznaním dôveryhodných zdrojov. Internet považujú viac ako miesto hladania odpovedí než ako analýzu skutočných informácií. Autori uvádzajú, že je dôležité viest' študentov $\mathrm{k}$ lepšiemu pochopeniu podstaty internetu a rozvíjat' u nich inštinktívny sklon k overovaniu všetkých informácií z tohto prostredia. Kubey (2002) v kontexte uvedeného zdôrazňuje význam mediálnej gramotnosti a tvrdí, že ak je ciel'om škôl naučit' žiakov kriticky mysliet', je dôležité učit' ich mediálnej gramotnosti a využívaniu elektronických médií ako miesta pre túto kritickú analýzu.

Kyberšikanovanie je vel'mi závažným sociálno-patologickým javom a preto považujeme za dôležité posilnit' realizovanie prevencie v školách z aspektu pedagogických, ale najmä odborných zamestnancov škôl a školských zariadení.

$\checkmark$ rámci vyučovacieho procesu má v škole významnú úlohu mediálna výchova. Vo výchovno-vzdelávacom procese nie je obsahovo zameraná na poznatky. Učitel' ju môže realizovat' vo forme prierezovej témy alebo ako samostatný predmet, a to s ciel'om naučit' žiakov hodnotit', selektovat' a využívat' informácie. Vel'mi vhodnými pre jej realizovanie sú triednické hodiny, počas ktorých môže triedny učitel' využívat' rôzne interaktívne metódy, pomocou ktorých môže zároveň vytvárat' pozitívnu klímu triedy a predchádzat' tak aj možnému kyberšikanovaniu medzi žiakmi. Vytvorenie pozitívneho prostredia nie len $v$ triedach, ale $v$ prostredí celej školy je v rámci prevencie kyberšikanovania vel'mi dôležitou úlohou (Niklová, 2015).

V súvislosti s mediálnou výchovou je dôležitým dokumentom Koncepcia mediálnej výchovy v Slovenskej republike v kontexte celoživotného vzdelávania z roku 2009. Táto 
koncepcia vymedzuje východiská mediálnej výchovy $v$ medzinárodnom a domácom kontexte, ale tiež aj mediálnu výchovu v kontexte celoživotného vzdelávania.

$\mathrm{K}$ relevantným dokumentom $\mathrm{v}$ oblasti prevencie kyberšikanovania patria: Akčný plán realizácie Koncepcie kybernetickej bezpečnosti Slovenskej republiky na roky 20152020,v ktorom je okrem iných oblastí rozpracovaná aj oblast' podpory, vypracovania a zavedenia systému vzdelávania v oblasti kybernetickej bezpečnosti (SK-CERT, 2018). Smernica č. $36 / 2018$ k prevencii a riešeniu šikanovania detí a žiakov v školách a školských zariadeniach, v ktorej je priamo definované kyberšikanovanie a jeho znaky (Smernica č. 36/2018. Národná koncepcia ochrany detí v digitálnom priestore na roky 2020-2021, ktorej hlavným ciel’om je v záujme zdravého vývinu detí a ich ochrany v digitálnom priestore podporovat' účinné opatrenia z oblasti prevencie, zvyšovania informovanosti a potláčania počítačovej kriminality.

Šikanovanie a kyberšikanovanie patrí k častým problémovým správaním vyskytujúcim sa v školskom prostredí, a to aj napriek implementácii novoprijatej smernice k prevencii a riešeniu šikanovania z roku 2018 do pedagogickej dokumentácie školy, oboznamovania žiakov $s$ touto problematikou a realizovania preventívnych aktivít. $V$ dokumente Prevencia a riešenie šikanovania a kyberšikanovania v základných a stredných školách z pohl'adu koordinátorov prevencie sa odporúča (Janková, 2020, s. 38):

- $\quad$ vymedzit' v rozvrhu škôl pevne stanovený počet hodín, ktoré budú vyčlenené iba na realizáciu preventívnych aktivít a preventívnych programov so zretel'om na šikanovanie alebo kyberšikanovanie,

- zahrnút' pôsobenie koordinátora prevencie do úväzku učitel'a,

- zvážit' nutnost' posilnit' pedagogický, resp. odborný tím v školách o sociálneho pedagóga,

- personálne posilnit' počet odborných zamestnancov v CPPPaP, ktorí sa venujú problematike prevencie a eliminácii šikanovania alebo kyberšikanovania,

- doplnit' a sprehl'adnit' preventívne programy a preventívne aktivity zamerané na šikanovanie a kyberšikanovanie,

- zabezpečovat' d'alšie možnosti vzdelávania učitel'ov v tejto oblasti, ako aj zvýšit' počet učitel'ov, ktorí dané vzdelávanie absolvovali.

Prudký nárast kyberšikanovania $v$ posledných rokoch prinútil odborníkov, aby sa intenzívnejšie začali zaoberat' stratégiami zvládania kyberšikanovania a jeho prevencie. Za prvý a najpodstatnejší krok pri tvorbe preventívnych opatrení odborníci považujú uvedomenie si problému. Kyberšikanovanie ovplyvňuje najmä deti v školskom prostredí, preto by škola mala prevenciu kyberšikanovania uskutočňovat' nasledovnými spôsobmi:

- Formálnym spôsobom prostredníctvom mediálnej výchovy a informatiky, organizovaním besied aplikovaných na problematiku kyberšikanovania, workshopov a iné. Dbat' na pozitívnu klímu v škole a zist'ovat' ju prostredníctvom anonymných dotazníkov a umožnit' žiakom prístup k informačným materiálom týkajúcich sa problematiky kyberšikanovania (Hanuliaková, Hollá, 2016).

- Neformálnym spôsobom prostredníctvom relaxačných aktivít pre žiakov, dbat' na pozitívnu klímu školy a dobré vzt’ahy by mali byt' jej súčast'ou, zriadenie "schránky dôvery", ktoré umožnia učitel'om riešit' problematiku kyberšikanovania a agresívneho správania priamo s rodičmi detí.

Efektívna prevencia kyberšikanovania by mala zahŕňat' nasledovné intervenčné opatrenia:

- jasné a zrozumitel'né zadefinovanie kyberšikanovania a sankcií pri nedodržaní pravidiel v školskom poriadku, ktorý bude sprístupnený všetkým žiakom,

- $\quad$ v prípade, ak sa kyberšikanovanie vyskytne na pôde školy, zaujat' negatívny postoj zo strany učitel'ov a odborníkov voči aktérom kyberšikanovania, no zároveň pozitívny $v$ zmysle podpory obeti, 
- poukazovat' na pozitívny prínos internetu a médií a podporovat' deti k bezpečnému využívaniu internetu,

- $\quad$ vymedzit' a zadefinovat' v školskom poriadku, že kyberšikanovanie na škole nie je za žiadnych okolností tolerované,

- informovanost' rodičov a žiakov o rizikách a dôsledkoch kyberšikanovania,

- stanovenie jasných pravidiel používania mobilných telefónov $v$ prostredí školy (Vyhláška ministerstva školstva č. 320/2008 Z. z. o základných školách, §20, ods. 7),

- zavedenie anonymnej evidencie, ktorá umožní nahlasovat' prípady kyberšikanovania bez pocit strachu alebo pomsty (Hinduja, Patchin, 2015).

Z vyššie prezentovaných výskumov jednoznačne vyplýva, že deti a mládež na uskutočňovanie kyberšikanovania používajú najčastejšie mobilné telefóny. Preto považujeme za potrebné podporovat' tiež zdravé využívanie mobilných telefónov $v$ prostredí škôl, aby sa predišlo vzniku kyberšikanovania. V tejto oblasti vidíme vel'ký zmysel práve $v$ spolupráci s rodičmi, ktorí by mali byt' informovaní o možných rizikách súvisiacich s používaním mobilných telefónov a ich následná podpora a usmerňovanie detí pri ich zmysluplnom používaní.

V prevencii kyberšikanovania sú vel'mi efektívne preventívne programy, zamerané na predchádzanie negatívnych dopadov používania internetu, mobilných telefónov a pod. Medzi najčastejšie preventívne programy patria napr.: Preventívny program MED, ktorý je zameraný na vybrané rizikové faktory vyplývajúce z každodenného mediálneho vplyvu; $\mathrm{Na}$ internete (ne)bezpečne, ktorého ciel'om je poskytnút' informácie o rizikách a nástrahách internetu a sociálnych sietí, venuje sa tiež problematike kyberšikanovania, problematike nadmerného používania mobilov; Kyberšikanovanie a kybergrooming, bezpečná online komunikácia, ktorý sa snaží poskytnút' prehl'ad hlavných ohrození vo virtuálnom svete a ponúka prehl'ad spôsobov ako sa pred nimi chránit'. Projekt Zodpovedne.sk - vznikol v roku 2007. Je zameraný na bezpečné a zodpovedné používanie internetu, mobilných telefónov a nových technológií. Jeho cielom je šírenie osvety, zvyšovanie povedomia a na predchádzanie trestných činov vo svete detí a mládeže. V rámci projektu Zodpovedne.sk je realizovaných viacero d'alších projektov.

Projekt Kyberšikanovanie.sk - je realizovaný pod záštitou projektu Zodpovedne.sk. Ciel'om projektu je rozšírit' vedomie a zvýšit' citlivost' na kyberšikanovanie a zmenit' pasívnych svedkov na aktívnych ochrancov obetí. Projekt Ovce.sk - patrí medzi najznámejšie realizované projekty. Ide o detský animovaný seriál, ktorý upozorňuje na hrozby internetu a mobilov. Projekt Nehejtuj.sk - témou projektu je netolerancia a ciel' vzdelávania prostredníctvom faktov a emócií. Projekt Stopline.sk - centrum pre nahlasovanie nezákonného obsahu alebo činnosti. Bojuje proti zneužívaniu detí, rasizmu a inej trestnej činnosti.

Projekt Pomoc.sk - projekt sa zameriava na poskytovanie špecializovaného poradenstva nie len det'om pre oblast' problémov, ktoré prinášajú moderné technológie. Projekt okrem iného venuje zvýšenú pozornost' aj vzt’ahom a komunikácií na sociálnych siet’ach a nevhodnému obsahu na internete. Projekt Detská policajná akadémia - je určený žiakom 6.-7. ročníka a je zameraný primárne na prevenciu kriminality a sekundárnou úlohou tohto projektu je predchádzanie inej protispoločenskej činnosti a sociálno-patologických javov. Čiastkové ciele sú rozpracované v piatich podprojektoch, pričom jeden z hlavných ciel'om s názvom Bezpečne na internete je venovaný komunikácii na sociálnych siet’ach, bezpečnému používaniu internetu a ochrane osobných údajov pri používaní internetu.

Preventívne prednášky môžu byt' v školách používané ako doplnková forma prevenčnej práce začlenená za podmienok spojenia s diskusiou na prezentovaný problém. Táto podmienka platí aj pre premietané filmov či iných názorných agitácií. Zároveň 
zdôrazňujeme, že účinná prevencia nesmie byt' vynútená zastrašovaním, či citovým apelovaním.

Adekvátnym doplnkom v prevencii na prvom stupni základnej školy, môžu byt' rozprávky OVCE.sk a OVCE.sk O2, ktoré vznikli $v$ rámci projektu Zodpovedne.sk a sú pokračovaním televízneho seriálu, pričom súčast'ou kníh je aj pexeso a DVD. Odborníci ale aj učitelia základných škôl publikácie hodnotia vel'mi pozitívne, nakol'ko ide o nenútenú formu prevencie, $v$ rámci ktorej už aj najmenšie deti vedia bez problémov rozpoznat' ponaučenie vyplývajúce z krátkych rozprávok. Prevencia sa nemôže uskutočňovat' prostredníctvom sporadických aktivít, musí byt' systematická, dlhodobá, a realizovaná pravidelne počas celého školského roka.

Významnú úlohu $v$ prevencii všetkých sociálno-patologických javov vrátane kyberšikanovania v školách má sociálny pedagóg. Sociálny pedagóg je podla zákona č. $318 / 2019$ o pedagogických zamestnancoch a odborných zamestnancoch zaradený v kategórii odborných zamestnancov školy. Je odborníkom, ktorý zabezpečuje nielen preventívne činnosti, ale poskytuje aj poradenstvo, zabezpečuje diagnostiku problémového správania žiakov. Pri odhalení kyberšikanovania v školskom prostredí, by mal sociálny pedagóg vyvinút' čo najväčšie úsilie, aby zamedzil d’alšiemu ubližovaniu a zaistil dôkazové materiály spolu s pomocou učitel'ov alebo iných pracovníkov školy, ktorí sú vyškolení v IKT oblasti. Po tomto kroku by mal sociálny pedagóg spolu s triednym učitel'om, riaditel'om školy prípadne d'alšími odbornými zamestnancami školy zabezpečit' opatrenia vzhl'adom na závažnost' situácie. Jedným z prvých opatrení by malo byt' kontaktovanie a oboznámenie rodičov, ktorých deti sa stali agresorom alebo obet'ou kyberšikanovania. Neodporúča sa ich vzájomná konfrontácia, ale individuálne konzultácie a následne šetrenie tomuto závažnému problému. Žiaden prípad kyberšikanovania by nemal ostat' nevyriešený, preto by škola po prešetrení prípadu mala trvat' na vyjadrení a konečnom stanovisku oboch zainteresovaných strán. Po vydaní záverečného stanoviska by agresor nemal ostat' nepotrestaný a mal by mu byt' udelený postih, ktorý vyplýva zo školského poriadku prípadne prijatí d’alších nariadení, ak išlo o priestupok závažnejšieho charakteru (www.prevence-info.cz).

V súvislosti s používaním IKT a internetu u mladých l'udí je potrebné upozornit' na to, že aj napriek ich skúsenostiam a schopnostiam s používaním digitálnych technológií, ich kritické myslenie má značné nedostatky a validitu informácií nedokážu dostatočne posúdit' a vyhodnotit', a práve preto sú ohrození falošnými správami a rôznymi pseudo informáciami (Shatto, Erwin, 2016). V tomto smere je preto nevyhnutné rozvíjat' u detí a mládeže kritické myslenie, aby dokázali selektovat' a overovat' informácie.

\section{Záver}

Kyberšikanovanie sa považuje za závažnú formu šikanovania, kedy páchatel' používa pri svojom agresívnom konaní moderné technológie - internet, počítač, mobilný telefón či smartphone a iné elektronické zariadenia. Agresívne správanie prebieha vo virtuálnom priestore. Pri tomto, kyberagresor využíva rôzne služby, nástroje a aplikácie - SMS správy, telefonáty, email, chatové miestnosti, blogy, diskusné fóra, sociálne siete a instant messengere ako napr. Messenger, Instagram, Snapchat, WhatsApp, Viber, Skype a d'alšie. Kyberšikanovanie nie je novým javom v spoločnosti, ale rozšírením tradičného šikanovania do e-prostredia, ktorý je determinovaný rozvojom nových technológií a elektronických médií. Prevencii kyberšikanovaniu je nutné venovat' pozornost' už na prvom stupni základných škôl. Primárnu prevenciu je nutné zabezpečovat' najmä cez rozvoj zdravej sociálnej klímy v triede, cez posilňovanie vzájomného partnerského vzt’ahu medzi žiakmi a posilňovanie prosociálneho a empatického správania žiakov $v$ intenciách nešpecifickej prevencie. Na druhom stupni základných škôl a v stredných školách odporúčame implementovat' najmä špecifickú 
prevenciu kyberšikanovania (a online rizikového správania) primeranej veku žiakov cez rôzne projekty zamerané na riešenú problematiku.

\section{Pod'akovanie}

Príspevok je jedným z priebežných výstupov riešenej výskumnej úlohy VEGA č. 1/0396/20 pod názvom „Vplyv elektronických médií na správanie a rozvíjanie prierezových spôsobilostí generácie Z“.

\section{Literatúra}

Barnová, S. - Krásna, S. (2018). Virtuálna generácia a aplikácia digitálnych technológií vo vyučovaní. E. Gajdošová, M. Madro, a M. Valihorová (Eds.), Zborník príspevkov z medzinárodnej vedeckej konferencie: Duševné zdravie a wellbeing virtuálnej generácie. Bratislava: IPčko.

Dulovics, M. (2012). Riziko vzniku mediálnych závislostí u žiakov základných a stredných škôl a možnosti prevencie z aspektu profesie sociálneho pedagóga. Banská Bystrica: Pedagogická fakulta UMB.

Dulovics, M. (2017). Kompulzívne správanie vo vzt’ahu k subsystému internetu ako forma online rizikového správania u detí a mládeže. In Manažment školy v praxi. Bratislava: Wolters Kluwer s.r.o. Roč. 12, číslo 9, s. 10 - 15.

Graham, L. - Metaxas, P. T. (2003). "Of course it's true; I saw it on the Internet!" Critical Thinking in the Internet Era. Communications of the ACM, 46(5), 71-75. Dostupné na https://jgregorymcverry.com/readings/S, $\% 20$ Nternet $\% 20-\% 202003 \% 20$ -

\%20T\%20RUE\%20I\%20S\%20AW\%20I\%20T\%200N.pdf

Gregussová, M. \& Kováčiková, D. (2008). Sú naše deti vo virtuálnom prostredí v bezpečí? Prevencia, 6(4), s. 22.

HINDUJA, S. \& PATCHIN. J. W. (2015). Bullying Beyond the Schoolyard. Preventing and Responding to Cyberbullying. USA: Corwin. 2015. $260 \mathrm{~s}$.

Hollá, K. (2008). Elektronické médiá a ich pôsobenie na agresívne správanie sa detí. Aktuálne otázky pedagogiky a psychológie 3 : zborník príspevkov z vedeckej konferencie, Banská Bystrica UMB.

Hollá, K. (2016). Sexting a kyberšikana. 1. vyd. Bratislava: IRIS.166 s.

Hollá, K. (2015). Kyberšikana v Slovenskej republike - analýza rozptylu hlavných efektov. In Slavonic Pedagogical Studies Journal. vol. 4, n. 2, s. 136-146

Hanuliaková, J. \& Hollá, K. (2016). School Social Climate - Cyberbullying Prevention. In Sexting a kyberšikana. Bratislava : 2016.

IZRAEL, P., HOLDOŠ, J., ĎURKA, J., HASÁK, M. (2019). Skúsenost' slovenských detí a mládeže so šikanovaním a sexuálnymi obsahmi na internete. Správa z výskumu EU Kids Online IV na Slovensku. Ružomberok. s.28.

Janková, M. (2020). Prevencia a riešenie šikanovania a kyberšikanovania v základných a stredných školách z pohl'adu koordinátorov prevencie. Bratislava: Centrum vedeckotechnických informácií SR. s. 38.

Kopecký, K. \& Szotkowski, R.(2016). Národní výskum kyberšikany českých učitelú výzkumná správa. Olomouc: PF UP. 21 s.

Kraus, B. (2008). Základy sociální pedagogiky. Praha: Portál.

Kubey, R. (2002). How media education promotes critical thinking, Democracy, health, and aesthetic appreciation. Dostupné na http://www.centerformedialiteracy.net/sites/default/files/547 CICML-Kubey.pdf

NIKLOVÁ, M. (2015). Prevencia mediálnych závislostí a deviantných foriem správania vo virtuálnom svete. In: EMMEROVÁ, I.-NIKLOVÁ, M.-DULOVICS, M. (2015): Základy mediálnej výchovy pre sociálnych pedagógov a pedagógov. Banská Bystrica. S.181-182. Niklová, M. (2018). Internet očami žiakov základných a stredných škôl v kontexte empirických zistení. Zborník vedeckovýskumných prác Katedry pedagogiky (14), Banská 
Bystrica, s. 23-32.

Poláková, E. (2013). Internetová komunikácia, príležitosti a riziká. Banská Bystrica: vydavatel'stvo UMB - Belianum. 117s.

Shatto, B. - Erwin, K. (2016). Moving on From Millennials: Preparing for Generation Z. The Journal of Continuing Education in Nursing, 47(6), 253-254. Dostupné na https://doi.org/10.3928/00220124-20160518-05

Šmahel, D. (2003). Psychologie a internet - děti dospělými, dospělí dětmi. Praha: Triton.

Trlicová, K. (2009). Nástrahy presiet'ovaného sveta. Quark, 4(11), s. 41.

www.prevence-info.cz

http://cyberbullying.org/summary-of-our-cyberbullying-research.

Smernica č. 36/2018 k prevencii a riešeniu šikanovania detí a žiakov v školách a školských zariadeniach.

Vyhláška ministerstva školstva č. 320/2008 Z. z. o základných školách.

Zákon č. 138/2019 o pedagogických zamestnancoch a odborných zamestnancoch.

\section{Adresy autorov}

Doc. PhDr. Miriam Niklová, PhD.

Katedra pedagogiky, Pedagogická fakulta, UMB v Banskej Bystrici Ružová 13, 974 11, Banská Bystrica miriam.niklova@umb.sk

\section{Mgr. Karina Zošáková}

Katedra pedagogiky, Pedagogická fakulta, UMB v Banskej Bystrici Ružová 13, 974 11, Banská Bystrica

karina.zosakova@umb.sk 


\title{
DIAGNOSTICKÉ A REFLEXÍVNE KOMPETENCIE ŠTUDENTOV UČITEL'STVA V PRAKTICKEJ PROFESIJNEJ PRÍPRAVE
}

\section{DIAGNOSTIC AND REFLEXIVE COMPETENCES OF TEACHING STUDENTS IN PRACTICAL PROFESSIONAL TRAINING}

\author{
Renáta Orosová \\ Katedra pedagogiky, Filozofická fakulta, UPJŠ v Košiciach \\ Mária Ganajová \\ Oddelenie didaktiky chémie, Prírodovedecká fakulta, UPJŠ v Košiciach \\ Ingrid Puchalová \\ Katedra germanistiky, Filozofická fakulta, UPJŠ v Košiciach
}

\begin{abstract}
:
Preparing professionally quality teachers for the needs of education in today's society is a challenge especially for teachers, because the precondition to development of key competences of students (call of OECD, TALIS or PISA assessment reports) is that teachers themselves have developed reflexive thinking and a high level of their professional competences. The aim of the study is to present the results of the analysis of the relationship between the level of evaluation of diagnostic and reflexive competences of teacher students from their own point of view as well as from the point of view of practicing teachers. An evaluation scale questionnaire developed according to the professional standard for primary and secondary school teachers was used to monitor the level of competences. The research tool was subjected to exploratory and confirmatory factor analysis. The value of the Cronbach's alpha indicates the optimal internal consistency of the scale questionnaire (0.801). 210 scientific teachers cooperating with UPJŠ in Košice and 115 students of teaching at UPJŠ took part in the research. The results of the research showed that there is a statistically significant difference in the level of diagnostic and reflexive competences of the student from the point of view of practicing teachers and the students of teaching themselves.
\end{abstract}

\section{Key words:}

student teachers, teacher trainer, professional competences, diagnostic competences, reflexive competences

\section{Úvod}

Učitel'ská profesia má sociálny, kultúrny, ekonomický, vedecký a technologický rozmer, vyvíja sa v závislosti od zmien v spoločnosti a je spojená od samého začiatku s vývojom l'udstva. Profesiu učitel'a môžeme radit' $\mathrm{k}$ najviac diskutovaným témam súčasnej spoločnosti. Kým v minulosti sa kládol dôraz predovšetkým na efektívnost' prezentovania poznatkov žiakom, dnes profesia učitel'stva smeruje k modelu profesionality. Svetové i národné výskumy smerujú $\mathrm{k}$ vnímaniu a postaveniu učitel'stva ako profesie, $\mathrm{k}$ porovnávaniu podmienok rozvoja učitel'skej profesie, ako i dopadu spoločenských zmien 
na učitel'skú profesiu (Cochran-Smith \& Zeichner, 2005; Darling-Hammond \& Bransford et al., 2005; Lukášová-Kantorková, 2003; National Research Council, 2010; Spilková \& Vašutová, 2008). V medzinárodnom meradle je možné sledovat' intenzívne hladanie spôsobov a ciest k zvyšovaniu kvality učitel'skej profesie, ako i podpore profesijného rozvoja učitel'ov počas ich pedagogickej praxe. Výskumne sú overované nové prístupy a modely prípravného vzdelávania učitel'ov. Učitel'ská profesia za posledné obdobie prešla od sústredenia sa na vzt'ah učitel' - žiak, žiak - učitel', až do dnešnej podoby sústredenia sa na vzt'ah učitel'a $k$ sebe samému. Požiadavka neustáleho sebazdokonal'ovania učitel'a, záujem o inovatívne možnosti výchovy a vzdelávania a sústavné prehodnocovanie vlastnej práce sa dostávajú do popredia mnohých reformných zmien so zámerom zvýšenia kvality profesie učitel'a.

Fenstermacher \& Richardson (2005, s. 205) zdôrazňujú, že zlepšovanie výučby učitela je klúčovým prvkom pri zlepšovaní vzdelávania žiakov. Zároveň poukazujú na priamy vzt'ah medzi kvalitou učitel'a a výsledkami žiakov. Kvalitné vyučovanie dávajú do súvisu s morálne obhájitel'nými a racionálnymi zásadami inštruktážnej práce učitela, pri ktorej je učitel' považovaný za najdôležitejšiu premennú v triede (Fenstermacher \& Richardson, 2005, s. 189; Sönmez, 2007, s. 252).

Koncepcie profesionalizácie učitel'stva smerujúce k reflexívnemu modelu sú celosvetovo považované za perspektívne vzhl'adom na kladený dôraz na systematickú reflexiu pedagogickej činnosti ako klúčového faktora profesijného rastu tak učitel'ov v praxi, ako i študentov učitel'stva (Spilková \& Vašutová et al., 2008). Proces stávania sa učitel'om profesionálom, reflexívnym praktikom, expertom na stretávanie sa so žiakom, nie je časovo obmedzeným procesom. Ide o proces, ktorý začína už v pregraduálnej príprave budúcich učitel'ov a pokračuje ako systematický a kontinuálny celoživotný proces profesijného sebazdokonal'ovania.

\section{Diagnostické a reflexívne kompetencie učitel'a}

Problematike profesijných kompetencií učitel'a sa v pedagogickej teórii oprávnene venuje stále viac pozornosti. Profesijné kompetencie učitel'a sú chápané ako súbor spôsobilostí učitel'a, jeho činnostné znalosti, zručnosti, zvládnuté výchovno-vzdelávacie operácie, postoje a presvedčenia (Kolář et al., 2012, s. 64). Vo vzt'ahu k učitel'skej profesii sú profesijné kompetencie nevyhnutné pre pedagogické pôsobenie, osvojujú si ich a rozvíjajú už budúci učitelia v rámci svojej praktickej profesijnej prípravy za asistencie cvičného učitel'a. Vzhl'adom k profesionalizácii učitel'stva môžeme hovorit' o učitel'ských kompetenciách ako o profesijných kompetenciách. Ide predovšetkým o profesijné kompetencie súvisiace s výkonom svojej budúcej profesie (Helus et al., 2012; Slávik et al., 2012, s. 77; Spilková et al., 2004):

- Odborno-predmetové kompetencie - poznatky z obsahu aprobačných predmetov, ich vedeckých základov, ktoré umožňujú prejavit' svoje odborné schopnosti v edukačnom procese; schopnost' aplikovat' praktickú skúsenost' z odboru, transformovat' odborné poznatky do obsahu učiva, vyhl'adávat' a spracovávat' informácie prostredníctvom informačných a komunikačných technológií.

- Psychodidaktické kompetencie - poznatky z pedagogických a psychologických vied, ktoré umožňujú vytvárat' priaznivé podmienky pre učenie (t. j. motivovat' žiakov k učeniu; aktivizovat' a rozvíjat' ich schopnosti); schopnost' používat' stratégie vyučovania a učenia sa žiakov, pracovat's vzdelávacím programom pri projektovaní vlastnej výuky, hodnotit' vzhl'adom k individuálnym osobitostiam žiakov.

- Komunikačné/komunikatívne kompetencie - efektívna komunikácia so žiakmi, kolegami, nadriadenými, rodičmi žiakov, sociálnymi partnermi; schopnost' 
vytvárat' pozitívnu klímu triedy, využívat' prostriedky pedagogickej komunikácie, orientovat' sa v náročných sociálnych situáciách.

- Diagnostické/intervenčné kompetencie - validne, reliabilne, spravodlivo a objektívne hodnotit' výkony žiakov; schopnost' používat' prostriedky pedagogickej diagnostiky, reflektovat' vzdelávacie potreby žiakov v pedagogickej práci, identifikovat' študentov so špecifickými potrebami, ovládat' spôsoby práce s nadanými žiakmi.

- Riadiace/organizačné kompetencie - efektívne plánovat' a projektovat' edukačný proces, správne organizovat' a riadit' výchovnú a vzdelávaciu činnost' žiakov; schopnost' pracovat' s platnými zákonmi, normami, dokumentmi, vytvárat' projekty na úrovni spolupráce s inými školami, zvládat' spôsoby vedenia žiakov a vytvárat' podmienky pre efektívnu spoluprácu v rámci skupín triedy.

- Poradenské a konzultatívne kompetencie - schopnost' poradit' študentom pri riešení ich problémov, individualizovat' výchovné pôsobenie; mat' vedomosti o právach človeka a rešpektovat' ich pri pedagogickej práci, individuálne pristupovat' $\mathrm{k}$ jednotlivým žiakom a riešeniu problémov.

- Reflexívne kompetencie - schopnost' reflexie vlastnej práce, hodnotenia vlastnej pedagogickej práce za účelom zlepšenia, zefektívnenia; mat' všeobecný rozhl'ad, vystupovat' ako reprezentant svojej profesie, byt' schopný sebareflexie na základe objektívneho ocenenia a sebahodnotenia.

Profesijné kompetencie majú nezastupitel'né miesto a význam pri rozvoji profesie učitel'a a jeho osobnosti ako profesionála. Učitel' vo svojej pedagogickej činnosti pracuje s osobnost'ami žiakov, ktoré sa snaží rozvíjat' vo všetkých oblastiach. Vzhl'adom ku snahám profesionalizácie učitel'stva je opodstatnený záujem o štandardizáciu profesijných kompetencií učitel'ov. Štáty Európskej únie poukazujú na skutočnost', že učitel'ská profesia je špecifická vo vzt'ahu k iným profesiám v spoločnosti a je nevyhnutná štandardizácia profesijných kompetencií.

Štandardizácia profesijných kompetencií je dôležitým procesom vyjadrenia normy pedagogických činností, ktoré sú preukázatel'né. Štandardizácia sa prejavuje v kontexte pedagogickej teórie, vzdelávacej politiky a pedagogickej praxe. Tieto kontexty by mali byt' vo vzájomnom prepojení bez výrazných konfliktov. Európska komisia (2012, s. 25 26) formulovala základnú štruktúru hlavných profesijných kompetencií učitel'a pre efektívne vyučovanie v 21. storočí v troch oblastiach: (a) vedomosti a porozumenie, (b) zručnosti, (c) dispozície (viera, postoje, hodnoty a záväzky).

Slovenský model profesijných štandardov pedagogických zamestnancov $v$ kategórii učitel' je tvorený vymedzenými profesijnými kompetenciami v troch dimenziách: žiak, výchovno-vzdelávací proces, profesijný rozvoj. Každá kompetencia obsahuje zložku vedomosti a zložku spôsobilosti.

Príprava budúcich učitel'ov druhého stupňa základnej školy a učitel'ov strednej školy musí vychádzat' z profesijných štandardov pre začínajúceho učitel'a. Absolvent učitel'skej prípravy by mal disponovat' príslušnými kompetenciami prejavujúcimi sa vedomost'ami a spôsobilost’ami $v$ jednotlivých oblastiach (pozn. spracované na základe komparácie profesijných štandardov pre začínajúceho učitel'a druhého stupňa základnej školy a začínajúceho učitel'a strednej školy; Pokyn ministra

a) v oblasti žiak:

- identifikovat' vývinové a individuálne charakteristiky žiaka,

- identifikovat' psychologické a sociálne faktory učenia sa žiaka,

- identifikovat' sociokultúrny kontext vývinu žiaka,

b) v oblasti výchovno-vzdelávací proces:

- ovládat' obsah a didaktiku vyučovacích predmetov, 
- plánovat' a projektovat' vyučovanie,

- realizovat' vyučovanie,

- $\quad$ hodnotit' priebeh a výsledky vyučovania a učenia sa žiaka,

c) v oblasti profesijný rozvoj:

- plánovat' a realizovat' svoj profesijný rast a sebarozvoj,

- stotožnit' sa s profesijnou rolou a školou.

Profesijné kompetencie študentov učitel'stva by sa mali rozvíjat' tak v rámci teoretickej prípravy, ako i v rámci praktickej profesijnej prípravy za aktívnej účasti cvičného učitela. Je potrebné si uvedomit', že praktikant realizuje vyučovací proces pod dohladom cvičného učitel'a ako mentora, supervízora a je zodpovedný za svoje konanie, preberá plnú zodpovednost' za svoju činnost' smerujúcu predovšetkým k žiakom. Cvičný učitel' smeruje praktikanta k reflexii vlastnej činnosti a sebareflexii za účelom zefektívnenia edukácie. K vedeniu praktikanta je však potrebná jeho rozvinutá diagnostická kompetencia, ktorá je základom úspešných rozborov vyučovacích hodín vedených reflexívnym rozhovorom cvičného učitel'a a praktikanta.

\section{Cvičný učitel' a študent učitel'stva v praktickej profesijnej príprave}

Praktická profesijná príprava je orientovaná na výkon samotného povolania. Táto čast' prípravy je realizovatel'ná $v$ dvoch krokoch: $v$ rámci predmetov didaktického charakteru študijných plánov učitel'stva jednotlivých fakúlt $v$ univerzitných podmienkach a ako samotná pedagogická prax študentov učitel'stva $v$ podmienkach cvičných škôl regionálneho školstva.

Pedagogická prax je v pedagogickom slovníku definovaná ako súčast' prípravy učitel'ov a vychovávatel'ov na pedagogických a iných fakultách s ciel'om spájat' teóriu a prax všetkých zložiek vysokoškolskej prípravy, uviest' budúceho učitel'a do podmienok reálneho školského prostredia a zacvičit' ho v činnostiach učitel'skej profesie (Průcha, Walterová \& Mareš, 2003, s. 156).

Pedagogická prax študentov učitel'stva je príprava na vyučovanie a každodenný život školy prostredníctvom praktického tréningu (Kosová \& Tomengová et al., 2015, s. 46). Ide predovšetkým o praktické prevedenie, skúšanie si vyučovacích metód, stratégií, techník vyučovania, ako i riadenie triedneho kolektívu, práce žiakov v rámci rôznych organizačných foriem a d'alších aktivít spojených s činnost'ou a pôsobením učitel'a $v$ reálnych pedagogických podmienkach. Pri realizácii pedagogickej praxe je najdôležitejšia implementácia teórie získanej počas teoretickej akademickej prípravy do pedagogickej školskej praxe.

Získanie profesijných kompetencií pre výkon povolania prepojením praktických skúseností s teoretickými vedomost’ami je hlavným ciel'om pedagogickej praxe (Kosová \& Tomengová et al., 2015, s. 47). Profesijné kompetencie sú zamerané na vzt'ah učitel'a $\mathrm{k}$ žiakovi, $\mathrm{k}$ výchovno-vzdelávaciemu procesu a vlastnému sebarozvoju.

Cvičný učitel' a cvičná škola sú termíny, ktoré sa v bežnej praxi používajú, avšak nie sú legislatívne ukotvené. Cvičný učitel', tak ako je uvedené vyššie, je pedagogickým zamestnancom základnej alebo strednej školy, ktorý sa v období pedagogickej praxe stáva spolupracovníkom vysokej školy (dohoda o vykonaní práce) vysielajúcej praktikantov na školu, kde pôsobí.

Cviční učitelia musia mat' požadovanú pedagogickú spôsobilost' na vyučovanie daného aprobačného predmetu a minimálne prvú atestáciu, resp. adekvátnu náhradu. Počas pedagogickej praxe študentov pôsobia ako:

- radcovia - poskytujú cenné rady týkajúce sa každodenného života v školskej triede, povzbudzujú praktikantov a pomáhajú im zvládat' počiatočné t’ažkosti, 
- $\quad$ zzory profesionálov - predvádzajú vzorový profesijný výkon v triede, rôzne prístupy k výučbe, rozmanité vyučovacie postupy, vzt’ah k žiakom, kolegom a pod.,

- informátori - informujú praktikantov o kurikule, dokumentácii, charakteristikách žiakov, vyučovacích stratégiách a i.,

- tréneri - zodpovedajú za výcvik praktikantov v príslušných pedagogických schopnostiach,

- pozorovatelia - pozorujú praktikantov v triede, ich činnost', správanie,

- poskytovatelia spätnej väzby - kriticky reflektujú a hodnotia priebeh a výsledky vlastnej činnosti,

- zhromažd'ovatelia informácií - zhromažd'ujú informácie o priebehu praxe praktikantov a poskytujú konštruktívnu správu a hodnotenie praxe praktikanta pre fakultu (Musai In Filová, 2002, s. 151 - 152).

Cvičný učitel' je profesionálnou podporou rozvoja osobnosti študenta učitel'stva vo všetkých zložkách, racionálnej, reflexno-vegetatívnej i emocionálno-afektívnej. Posilňuje autonómiu praktikanta vo vzt'ahu $\mathrm{k}$ sebe samému, k vlastnému rozvoju či k cvičnému učitel'ovi i k učitel'skej profesii (Kosová \& Tomengová et al., 2015, s. 52).

Aktívna účast' praktikanta na pedagogickej praxi je podmienená i prístupom cvičného učitel'a. Cvičný učitel' nie je len poskytovatel'om informácií, pri ktorých praktikant napodobňuje a trénuje profesijné zručnosti, ale sám svojím vzorom smeruje študenta $\mathrm{k}$ poznaniu a trvalým zmenám. Praktikantovi vytvára pocit bezpečia, vedie ho $\mathrm{k}$ zodpovednosti za svoje rozhodovanie, konanie a prispieva k uvedomeniu si praktikanta svojho vzt’ahu k učitel'skej profesii. Cvičný učitel' je v roli supervízora (Cooper, 1995) alebo mentora (Píšová \& Duschinská, 2011), ktorý v rámci rozboru vyučovacej hodiny zámerne a cielene pomocou facilitovaných otázok vytvára situácie zamerané na spätný pohl'ad na realizované vyučovacie sekvencie, uvedomenie si podstatných aspektov vyučovania, vytváranie alternatívnych stratégií konania s možnost'ou generalizácie na situácie vyučovania.

Aby cvičný učitel' mohol efektívne viest' praktikanta na praxi a následne s ním realizovat' efektívny a rozvíjajúci rozbor vyučovacej hodiny, je potrebné, aby sám ako reflexívny praktik disponoval diagnostickými kompetenciami, ktoré môže rozvíjat' len za predpokladu osvojenia si trojstupňového modelu pedagogickej diagnostiky.

\section{Metodológia}

Výskum bol zameraný na profesijné kompetencie študentov učitel'stva s dôrazom na diagnostické a reflexívne kompetencie. Ciel'om výskumu bolo zistit' úroveň diagnostických a reflexívnych kompetencií študentov učitel'stva z pohl'adu cvičných učitel'ov a samotných študentov učitel'stva.

Na deskripciu a analýzu názorov cvičných učitel'ov a študentov učitel'stva sme použili variant deskriptívneho výskumu, ktorého ciel'om bolo zhromaždit' výskumný materiál podrobne opisujúci jednu ústrednú premennú - názory cvičných učitel'ov zo základných a stredných škôl a študentov učitel'stva na úroveň profesijných kompetencií študentov učitel'stva, a to $v$ troch oblastiach - v oblasti žiak, výchovno-vzdelávací proces a sebarozvoj učitel'a (študenta učitel'stva). Jednotlivé oblasti obsahovali položky vzt’ahujúce sa na konkrétnu oblast' kompetencií, t. j. na akej úrovni študent uskutočňuje konkrétne činnosti. Pre potreby tejto štúdie sme sa zamerali na diagnostické a reflexívne kompetencie študentov učitel'stva, zamerali sme sa na oblast' žiak.

V oblasti žiak sme sledovali úroveň kompetencií v troch faktoroch:

- identifikácia vývinových a individuálnych charakteristík žiaka - tvorili ho 4 položky,

- identifikácia psychologických a sociálnych faktorov učenia - tvorili ho 3 položky, 
- identifikácia sociokultúrneho kontextu vývinu žiaka - tvorili ho 3 položky, Cviční učitelia a študenti učitel'stva mali k dispozícii škálový hodnotiaci dotazník vlastnej tvorby, v ktorom sa vyjadrovali k jednotlivým položkách pomocou pät'stupňovej Likertovej škály (1 - nedostatočne; 2 - dostatočne; 3 - dobre; 4 - vel'mi dobre; 5 - výborne). Hodnotiaci dotazník bol vytvorený podla profesijných štandardov pre učitel'ov základných a stredných škôl. Hodnotiaci dotazník pre cvičných učitel'ov bol zameraný na heteronómne hodnotenie profesijných kompetencií študentov učitel'stva a hodnotiaci dotazník pre študentov učitel'stva bol zameraný na autonómne hodnotenie ich profesijných kompetencií. Hodnotiace dotazníky sa odlišovali iba vo faktografických údajoch potrebných $\mathrm{k}$ triedeniu dát pre štatistické spracovanie. Pri hodnotiacom dotazníku pre cvičných učitel'ov sme položky zamerali na: vek, rod, pôsobisko, dížku pedagogickej praxe a predmet, pre ktorý sú vedení ako cviční učitelia. Pri hodnotiacom dotazníku pre študentov sme položky zamerali na rod a aprobačné predmety, pre ktorých vyučovanie získajú kvalifikáciu.

Konštruktovú validitu sme overovali exploračnou faktorovou analýzou (PCA s varimaxovou rotáciou). Položky dotazníka sme podrobili exploračnej faktorovej analýze pomocou SPSS Statistics 20. Jej vhodnost' použitia sme zistili Kaiser-Meyer-Olkinovým (KMO) testom a Bartlettovým testom sféricity. Hodnota KMO testu miery adekvátnosti výberu bola 0,823 , čo môžeme považovat' za vel'mi dobrú (Hutcheson \& Sofroniou, 1999). Bartlettov test sféricity vyvrátil hypotézu, že je korelačná matica maticou jednotkovou $(p<0,001)$. Výsledky testov nám umožnili využívat' exploračnú faktorovú analýzu pri identifikácii dimenzionality nástroja a posúdení hodnosti zaradenia jednotlivých položiek dotazníka do d’alších analýz. Kritériom pre vhodnost' položiek bol koeficient komunality a minimálna faktorová zát'až položky pre jej zaradenie do jedného z faktorov 0,40 . Na potvrdenie dimenzionality sme d’alej vykonali paralelnú analýzu, ako najoptimálnejšie riešenie bol identifikovaný devät'faktorový model analyzovanej verzie dotazníka profesijných kompetencií študentov učitel'stva. Faktory sme označili v súlade $s$ terminológiou profesijného štandardu učitel'a ISCED 2 a ISCED 3 . Reliabilitu (spol'ahlivost'), vnútornú konzistenciu výskumného nástroja, teda vzt'ah medzi položkami výskumného nástroja navzájom a vzt’ah medzi položkami a výskumným nástrojom ako celkom sme zist'ovali štatistickým softvérom SPSS Statistics 20, prostredníctvom Cronbachovho koeficientu alpha. Hodnotiaci dotazník vykazoval vel'mi dobrú reliabilitu, hodnota koeficientu Cronbachovho koeficientu alpha $\alpha=0,801$ bola nad minimálnou hodnotou $\alpha=0,700$. Reliabilita dimenzie žiak (diagnostická) mala hodnotu Cronbachovho koeficientu alpha $\alpha=0,789$, Korelácie medzi jednotlivými položkami sa pohybovali $v$ rozmedzí <0,039; 0,677>, pričom boli štatisticky významné na hladine významnosti $p<0,05$. Korelácie medzi jednotlivými položkami a celkovým skóre sa pohybovali vo všetkých prípadoch nad hranicou 0,50 . Všetky položky sme tak mohli zaradit' do d'alších analýz a nemuseli sme žiadnu vyradit'. Na základe hodnoty Spearmanovho koeficientu korelácie možno povedat', že medzi dimenziami existuje silná korelácia $(p<0,001)$. Výsledky faktorovej analýzy spolu s hodnotami koeficientu Cronbachovho alfa indikujú vnútornú konzistenciu jednotlivých faktorov.

\section{Charakteristika výberového súboru}

Základný súbor tvorili študenti učitel'stva a ich cviční učitelia zo základných a stredných škôl v Košickom kraji. Výberový výskumný súbor bol podriadený zámernému dostupnému výberu študentov učitel'stva a cvičných učitel'ov UPJŠ v Košiciach. Do výskumu boli zaradení študenti učitel'stva UPJŠ (študenti Filozofickej fakulty a Prírodovedeckej fakulty), ktorí absolvovali súvislú pedagogickú prax ako i ich cviční učitelia zo základných a stredných škôl. Výberový súbor tak nebol náhodný. Náhodný nebol ani výber cvičných učitel'ov, pretože do výskumu boli zapojení práve tí, ktorí mali študentov tvoriacich výberový súbor na súvislej pedagogickej praxi. Výberový výskumný 
súbor pre realizáciu dotazníkového šetrenia sme zostavili technikou dostupného výberu, tvorilo ho 210 učitel'ov ZŠ a SŠ a 115 študentov učitel'stva na UPJŠ.

\section{Výsledky výskumu}

Schopnost' zhodnotit' vlastnú činnost' je základným pilierom reflexívnych kompetencií. Výsledky výskumu sú analyzované na základe komparačnej analýzy autonómneho hodnotenia študentov učitel'stva a heterenómneho hodnotenia cvičných učitel'ov.

Tab. 1 Úroveň kompetencií - autonómne a heteronómne hodnotenie

\begin{tabular}{|c|c|c|c|}
\hline Kompetencia/vedomosti/spôsobilosti & Š & U & rozdiel \\
\hline \multicolumn{4}{|l|}{ Identifikovat' vývinové a individuálne charakteristiky žiaka (K) } \\
\hline $\begin{array}{l}\text { ovláda biologické, psychologické a sociologické aspekty vývinu } \\
\text { žiakov }(\mathrm{V})\end{array}$ & 4,42 & 3,63 & 0,79 \\
\hline pozná teoretické východiská pedagogickej diagnostiky (V) & 4,72 & 3,25 & 1,47 \\
\hline $\begin{array}{l}\text { tvorivo a efektívne využíva vedomosti na identifikovanie } \\
\text { individuálnych charakteristík žiaka (S) }\end{array}$ & 4,65 & 3,11 & 1,54 \\
\hline $\begin{array}{l}\text { má základné praktické skúsenosti s identifikáciu individuálnych } \\
\text { charakteristík žiaka (S) }\end{array}$ & 3,99 & 2,86 & 1,13 \\
\hline Priemer - kompetencia & 4,45 & 3,21 & 1,23 \\
\hline \multicolumn{4}{|l|}{ Identifikovat' psychologické a sociálne faktory učenia sa žiaka (K) } \\
\hline $\begin{array}{l}\text { pozná a chápe koncept inštitucionálneho socializačného procesu } \\
\text { v širších sociálno-vedných súvislostiach }(\mathrm{V})\end{array}$ & 4,13 & 3,18 & 0,95 \\
\hline $\begin{array}{l}\text { identifikuje učebný štýl a individuálne výchovno-vzdelávacie } \\
\text { potreby žiakov - intaktní žiaci, žiaci so špeciálnymi výchovno- } \\
\text { vzdelávacími potrebami (S) }\end{array}$ & 4,49 & 3,46 & 1,03 \\
\hline identifikuje individuálne charakteristiky žiaka (S) & 4,37 & 3,33 & 1,04 \\
\hline Priemer - kompetencia & 4,33 & 3,32 & 1,01 \\
\hline \multicolumn{4}{|l|}{ Identifikovat' sociokultúrny kontext vývinu žiaka (K) } \\
\hline ovláda problematiku multikulturality vo vzt’ahu k žiakovi (V) & 4,66 & 3,85 & 0,81 \\
\hline $\begin{array}{l}\text { má základné praktické skúsenosti s identifikáciou špeciálnych } \\
\text { výchovno-vzdelávacích potrieb žiakov v sociokultúrnom kontexte } \\
\text { (S) }\end{array}$ & 4,57 & 3,21 & 1,36 \\
\hline akceptuje diverzitu žiakov v sociokultúrnom kontexte (S) & 4,61 & 3,55 & 1,06 \\
\hline Priemer - kompetencia & 4,61 & 3,54 & 1,08 \\
\hline Priemer - dimenzia & 4,46 & 3,36 & 1,11 \\
\hline
\end{tabular}

Legenda: K - kompetencia; V - vedomosti; S - spôsobilosti; Š - študent; U - učitel' Zdroj: vlastné spracovanie

Úroveň diagnostických kompetencií v dimenzii žiak je z pohl'adu študentov učitel'stva hodnotená vel'mi vysoko. Študenti hodnotili úroveň svojich kompetencií v dimenzii žiak diagnostické kompetencie ako vel'mi dobrú úroveň. Pri identifikácii sociokultúrneho kontextu vývinu žiaka takmer výbornú. Svoje diagnostické kompetencie v dimenzii žiak študenti $(4,46)$ mali tendenciu hodnotit' lepšie ako ich cviční učitelia $(3,36)$. Rozdiel v hodnotení dosiahol viac ako 1 hodnotiaci stupeň $(1,11)$. Cviční učitelia hodnotili kompetencie študentov $v$ dimenzii žiak ako dobré. $Z$ tabul'ky 1 je zrejmé, že úroveň 
vedomostí študentov v dimenzii žiak je vyššia ako úroveň ich spôsobilostí v tejto oblasti. Taktiež je to možné sledovat' i pri heteronómnom hodnotení učitel'ov.

Výsledky výskumu $v$ oblasti žiak nám naznačujú štatisticky významné rozdiely v autonómnom a heteronómnom hodnotení úrovne kompetencií v oblasti žiak. Študenti vykazovali nižšiu úroveň reflexívnych kompetencií, pretože sa od heteronómneho hodnotenia učitel'ov značne odkláňali.

Pri štatistickej verifikácii týchto rozdielov sme sa snažili zistit', či sa študenti priblížili ku hodnoteniu učitel'ov štatisticky významne. Ked'že každý študent získal dve hodnotenia od cvičného učitel'a, spriemerovali sme ich, aby sme zredukovali faktor subjektívnosti. Následne sme porovnali priemerné hodnotenie študenta $v$ dimenzii žiak a priemerné hodnotenie učitel'a $v$ dimenzii žiak a získali sme odchýlku hodnotenia študenta od učitela v oblasti žiak. Priemerný rozdiel $v$ odchýlke $v$ rámci porovnávania autonómneho hodnotenia študentov a heteronómneho hodnotenia učitel'ov v oblasti žiak je 1,11.

Či tento rozdiel je signifikantný sme zist'ovali štatistickými metódami. Pri KolmogorovSmirnovho teste normality sme zistili, že dáta nemajú normálne rozloženie, pretože získané hodnoty boli nižšie ako 0,05. Vzhl'adom k týmto výsledkom sme využili neparametrický Mann-Whitney U-test pre 2 nezávislé výbery. Týmto testom ste verifikovali hypotézu.

H1: Úroveň diagnostických kompetencií študentov učitel'stva je v oblasti žiak z pohladu študentov vyššia ako z pohladu cvičných učitel'ov.

Hypotéza sa nám potvrdila na hladine významnosti $p<0,001$. Verifikáciou hypotézy sme zistili, že študenti svoje diagnostické kompetencie hodnotia vyššie ako ich cviční učitelia. Signifikantné rozdiely v hodnotení nám predikujú zároveň úroveň reflexívnych kompetencií študentov učitel'stva. Študenti učitel'stva majú tendenciu sa lepšie hodnotit', avšak úroveň ich reflexívnych kompetencií je nižšia.

\section{Diskusia a záver}

Kvalita učitel'a je podl'a Fenstermachera a Richardsona (2005, s.205) v priamom vzt'ahu s výsledkami žiakov. Pripravit' kvalitných učitel'ov pre potreby výchovy a vzdelávania v súčasnej spoločnosti je výzvou predovšetkým pre učitel'ské prípravky. Učitel' súčasnosti má mat' na vysokej úrovni rozvinuté svoje profesijné kompetencie a predovšetkým má naplńat' atribúty reflexívneho praktika. Jedným zo spôsobov rozvoja profesijných kompetencií je praktická profesijná príprava učitel'ov prostredníctvom pedagogickej praxe. Pedagogická prax ponúka priestor na rozvoj diagnostických kompetencií študentov učitel'stva, ktorí prichádzajú do priameho kontaktu so žiakmi v reálnej školskej praxi a v rámci rozborov vyučovacích hodín rozvíjajú svoje reflexívne kompetencie.

Autonómne hodnotenie spočíva v sebahodnotení študenta, ktoré vie zdôvodnit', obhájit'. Ide o hodnotenie vlastných možností, vlastností, schopností a postavenia medzi inými l'ud'mi (Kosová, 2002, s.16). Autonómne hodnotenie študentov vel'mi úzko súvisí s ich reflexívnymi kompetenciami, pretože pri procese hodnotenia študent analyzuje svoju činnost', svoje konanie a spätne nazerá na svoju reakciu. Viaceré výskumy skúmajúce autonómne hodnotenie žiakov, predovšetkým vo vzt’ahu k školskej úspešnosti (Lee \& Bong 2014, Starý \& Laufková, et al., 2016), poukazujú na skutočnost', že sa študenti zvyknú lepšie hodnotit' ako ich hodnotí učitel'. Toto tvrdenie sme potvrdili i našim výskumom, kedy študenti učitel'stva sa lepšie hodnotili svoju úroveň kompetencií $v$ dimenzii žiak.

Hodnotenie ako interpretačná procedúra je zamerané na vybranú oblast' reality (Slavík, 2003, s.8). V našom prípade išlo o hodnotenie profesijných kompetencií cvičnými učitel'mi (heteronómne hodnotenie) a samotnými študentmi učitel'stva (autonómne hodnotenie). Autonómne hodnotenie je pre budúcich učitel'ov vel'mi dôležitá súčast' ich prípravy na profesiu učitela. Pri autonómnom hodnotení ide o hodnotenie svojej vlastnej činnosti, zdôvodnenie svojho hodnotenia a snahy o jej zlepšenie na základe výsledku 
hodnotenia (Jedlička, Kot'a, \& Slavík, 2018, s.8). Autonómne hodnotenie učitel'ov je dôležitou súčast' rozvoja ich profesijných kompetencií a základom pre objektívne heteronómne hodnotenie žiakov. Výsledky nami realizovaného výskumu potvrdili dôležitost' autonómneho hodnotenia $v$ učitel'skej príprave, a viedli nás $\mathrm{k}$ d'alším výskumným šetreniam zameraným na zvýšenie efektívnosti autonómneho hodnotenia, napríklad v rámci realizácie hodnotenia vlastných výstupov študentov, sebahodnotenia, vrstovníckeho hodnotenia.

Ciel’om výchovy a vzdelávania v súčasnom školskom prostredí je komplexný osobnostný rozvoj žiaka. Profesijné kompetencie učitel'a sú preto orientované i na žiaka. Walberg (1984) poukázal, že správanie sa učitel'ov k žiakom má značný vplyv tak na osobnost' žiaka, ako i výsledok výchovno-vzdelávacieho procesu. Budúci učitel' ako reflexívny praktik má byt' schopný identifikovat' a analyzovat' problémy a situácie z pedagogického, psychologického i sociálneho hl'adiska a uskutočňovat' zodpovedné rozhodnutia (Nezvalová, 2000). Zodpovedné rozhodnutia je možné realizovat' len v prípade, že učitel' si pomocou reflexie uvedomí svoje nedostatky, ale i možnosti v oblasti rozvoja osobnosti žiaka, svoju úroveň identifikácie vývinových a individuálnych charakteristík žiaka, jeho psychologických a sociálnych faktorov učenia sa, ako i sociokultúrneho kontextu vývinu žiaka.

Výsledky výskumu a štatistická verifikácia hypotézy nám potvrdili, že úroveň diagnostických kompetencií študentov učitel'stva je v oblasti žiak z pohl'adu študentov vyššia ako z pohl'adu cvičných učitel'ov. Táto hypotéza sa potvrdila na vysokej hladine významnosti 0,001 . Z uvedeného je potrebné pripravit' podmienky v rámci pregraduálnej prípravy na rozvoj diagnostických kompetencií študentov učitel'stva práve vo vzt'ahu k žiakom. Je možné využívat' rôzne rolové hry, simulačné aktivity, pri ktorých si študenti rozvíjajú svoje diagnostické kompetencie.

Ideálny priestor pre rozvoj diagnostických kompetencií študentov učitel'stva je práce počas pedagogickej praxe, kedy za pomoci cvičných učitel'ov ich dokážu efektívne rozvíjat'. V tomto smere sú potrebné aktívne stretnutia, metodické sedenia a workshopy pre cvičných učitel'ov s ciel'om odbornej podpory pri mentoringu cvičného učitel'a.

Slavík et al. (2012) spája reflexiu predovšetkým s didaktickým myslením učitel'a, jeho rozvojom a možnost'ami ovplyvňovania pedagogickej činnosti učitel'a. Učitel' pri reflexii premýšl'a nad didaktickými udalost'ami v rámci vyučovacej hodiny, analyzuje ich a hl'adá riešenie na ich zefektívnenie (Nezvalová, 2007). Výchovno-vzdelávací proces tvorí základ pedagogickej činnosti učitel'a a je zároveň najrozsiahlejšou oblast'ou kompetenčného profilu učitel'a. Profesijné kompetencie učitel'a sa v tejto oblasti viažu nielen na ovládanie obsahu a didaktiky vyučovaných predmetov, ale predovšetkým na plánovanie, projektovanie, realizáciu výchovno-vzdelávacieho procesu a hodnotenie jeho výsledkov a učenie sa žiaka. Učitel' by mal poznat' svoje možnosti, ale i nedostatky a pracovat' na ich odstránení. To je možné iba v dôsledku reflexie. Autodiagnostikovanie a profesijná reflexia sú predpokladom pre realizáciu reflexívnej výučby (Ferencová \& Kosturková, 2020), ktorá je považovaná za základnú kompetenciu k profesijnému rastu. $\checkmark$ rámci pregraduálnej prípravy je tak žiadúce využívat' rôzne reflexívne techniky na rozvoj profesijných kompetencií študentov učitel'stva, ako napríklad pedagogický denník, reflexívny rozhovor s mentorom, mikroedukáciu a mikroedukatívne analýzy.

\section{Pod'akovanie}

Príspevok vznikol s podporou projektu VVGS-2020-1665 „Diagnostická kompetencia cvičného učitel'a ako reflexívneho praktika“. 


\section{Literatúra}

Cochran-Smith, M., \& Zeichner, K. M. (2005). Studying teacher education: The report of the AERA panel on research and teacher education. Washington, D. C.: American Educational Research Association.

Cooper, J. L. (1995). Cooperative Learning and Critical Thinking. Teaching of Psychology, 22(1), 7-9. https://doi.org/10.1207/s15328023top2201 2

Darling-Hammond, L., \& Bransford, J. D. et al. (2005). Preparing teachers for a changing world: What Teachers Should Learn and Be Able to Do. San Francisco: Jossey-Bass.

European Commision. (2012). Key data on education in Europe 2012. Key Data Series. Eurydice. $\quad$ https://eacea.ec.europa.eu/national-policies/eurydice/content/key-dataeducation-europe-2012 en

Fenstermacher, G. D., \& Richardson, V. (2005). On making determinations of quality in teaching. Teachers College Record, 107(1), 186-213.

Ferencová, J., \& Kosturková, M. (2020). Kapitoly z didaktiky. Od učenia sa k vyučovaniu. Prešov: Rokus.

Filová, H. (2002). Intervence cvičných učitelů v procesu vytváření pedagogických dovedností studentů učitelství primární školy. In B. Kasáčová (Ed.), Spolupráca univerzity a škôl. Zborník príspevkov z medzinárodnej konferencie Cvičný učitel'. 18. 1. 2002 (s. 151-160). Banská Bystrica: Pedagogická fakulta UMB.

Helus, Z., Bravená, N., \& Franclová, M. (2012). Perspektivy učitelství. Praha: Pedagogická fakulta UK.

Jedlička, R., Kot’a, J., \& Slavík, J. (2018). Pedagogická psychologie pro učitele: psychologie ve výchově a vzdělávání. Praha: Grada.

Kolář, Z. et al. (2012). Výkladový slovník z pedagogiky. 583 vybraných hesel. Praha: Grada Publishing.

Kosová, B., \& Tomengová, A. et al. (2015). Profesijná praktická príprava budúcich učitelov. Banská Bystrica: Belianum.

Lee, W., Lee, M.J., \& Bong, M. (2014). Testing interest and self-efficacy as predictors of academic self-regulation and achievement. Contemporary Educational Psychology, 39(2), 86-99. https://doi.org/10.1016/j.cedpsych.2014.02.002

Lukášová-Kantorková, H. (2003). Učitelská profese v primárním vzdělávaní a pedagogická príprava učitelů (teorie, výzkum, praxe). Ostrava: Pedagogická fakulta OU.

National Research Council. (2010). Preparing teachers: Building evidence for sound policy. Washington, D. C.: The National Academies Press.

Nezvalová, D. (2002). Reflexe a pregraduální didaktická př́íprava učitele. e-Pedagogium, 2(2), s. 69-82.

Nezvalová, D. (2007). Pedagogická praxe v počáteční prípravě učitelů prírodovědných předmětů a matematiky pro střední školy. Olomouc: Univerzita Palackého v Olomouci.

Píšová, M., \& Duschinská, K. (2011). Mentoring v učitelství: výzkumný záměr. Učitelská profese $v$ měnících se požadavcích na vzdělávání. Praha: Univerzita Karlova v Praze, Pedagogická fakulta.

Pokyn ministra č. 39/2017, ktorým sa vydávajú profesijné štandardy pre jednotlivé kategórie a podkategórie pedagogických zamestnancov a odborných zamestnancov škôl a školských zariadení. (2017). https://www.minedu.sk/pokyn-ministra-c-392017-ktorymsa-vydavaju-profesijne-standardy-pre-jednotlive-kategorie-a-podkategorie-

pedagogickych-zamestnancov-a-odbornych-zamestnancov-skol-a-skolskych-zariadeni/ Průcha, J., Walterová, E., \& Mareš, J. (2003). Pedagogický slovník (4th Ed.). Praha: Portál. 
Slavík, J. (2003). Autonomní a heteronomní pojetí školního hodnocení - aktuální problém pedagogické teorie a praxe. Pedagogika, LIII (1), 2003. s.5-25. Dostupné na: https://pages.pedf.cuni.cz/pedagogika/?p=1897\&lang=cs

Slávik, M. et al. (2012). Vysokoškolská pedagogika. Praha: Grada.

Sönmez, V. (2007). Ögretim ilke ve yöntemleri (Teaching principles and methods). Ankara: Ani Yayincilik.

Spilková, V. et al. (2004). Současné proměny vzdělávaní učitelů. Brno: Paido.

Spilková, V., \& Vašutová, J. (2008). Učitelské profese v měnících se požadavcích na vzdělávání: výzkumný záměř. Úvodní teoreticko-metodologické studie. Praha: Pedagogická fakulta UK.

Starý, K., \& Laufková, V. et al. (2016). Formativní hodnocení ve výuce. Praha: Portál. Walberg, H. J. (1984). Improving the productivity of American schools. Educational Leadership, 41(8), s. 9-27.

\section{Adresy autorov}

Doc. PaedDr. Renáta Orosová, PhD.

Katedra pedagogiky, Filozofická fakulta, UPJŠ v Košiciach

Moyzesova 9, 04001 Košice

renata.orosova@upjs.sk

Doc. RNDr. Mária Ganajová, CSc.

Oddelenie didaktiky chémie, Prírodovedecká fakulta, UPJŠ v Košiciach

Moyzesova 11, 04001 Košice

maria.ganajova@upjs.sk

Doc. PaedDr. Ingrid Puchalová, PhD.

Katedra germanistiky, Filozofická fakulta, UPJŠ v Košiciach

Moyzesova 9, 04001 Košice

ingrid.puchalova@upjs.sk 


\title{
ANDRAGOGICKÉ PORADENSTVO AKO INTEGRÁLNA SÚČASŤ EDUKAČNÉHO PORADENSTVA
}

\section{ANDRAGOGICAL COUNSELING AS AN INTEGRAL PART OF COUNSELING IN EDUCATION}

\author{
Ivan Pavlov \\ Katedra andragogiky, Pedagogická fakuta, UMB v Banskej Bystrici \\ Martin Schubert \\ Katedra andragogiky, Pedagogická fakulta, UMB v Banskej Bystrici
}

\begin{abstract}
:
The paper presents the theoretical model of andragogical counseling as an integral part of the complex approach in educational counseling. The model is incorporated into broader socio-economic and international relationships, as well as interdisciplinary contexts. It will describe the goals, functions, approaches and specifics of learningrelated counseling for adults.
\end{abstract}

Key words:

the adult, learning, lifelong learning, educational counseling, andragogical counseling, learning ability, the counselor, the client

\section{Úvod}

V ostatnom období vzrastá záujem o komplexnú podporu procesov celoživotného učenia sa človeka. Dokumenty z prostredia Európskej únie (2000; 2008; 2018) kladú mimoriadny dôraz na úlohu národných mechanizmov podpory celoživotného učenia, osobitne vzdelávania a učenia sa dospelých.

V Európe možno uviest' mnoho príkladov krajín s funkčnými stratégiami, systémami podpory, ktoré vedú $\mathrm{k}$ dlhodobo vysokej účasti dospelých na d’alšom vzdelávaní, ich vysokej motivácii prekonávat' rôzne učebné výzvy, problémy či bariéry najmä pomocou poradenstva. Na Slovensku, žial', doposial' neexistuje platná národná stratégia podpory celoživotného učenia a poradenstva, nástroje podpory učenia sa dospelých sú OECD (2020) hodnotené ako nedostatočné. Slovensko potrebuje zásadne zmenit' svoj prístup ku koncepcii a systému podpory celoživotného učenia, začat' ich vnímat' ako významné komponenty ekonomického rozvoja spoločnosti a kvality života občanov. Pedagogika a andragogika môžu k tomuto rozvoju prispiet' interdisciplinárne založeným výskumom, komparatívnym štúdiom funkčných zahraničných systémov a uváženou adaptáciou ich prvkov na naše podmienky. Za významný príspevok v tomto úsilí považujeme rozvoj andragogickej teórie, predovšetkým však kontextualizáciu, konceptualizáciu a tvorbu inovatívnych prístupov $v$ učebnom poradenstve pre dospelých, t. j. v andragogickom poradenstve.

\section{Celoživotné, edukačné a andragogické poradenstvo}

Poradenstvu sa v ostatných desat'ročiach pripisuje čoraz väčší vedecký a spoločenských význam. Ako dôvody sa často uvádzajú spoločenské, ekonomické, technologické a politické zmeny, ktoré zvyšujú potrebu orientácie a podpory pri rozhodovaní. Využívanie internetu, ako zdroja informácií variabilnej kvality, vyžaduje od jednotlivca 
spôsobilost' kriticky uvažovat'. Status dospelého však nemusí byt' zárukou tejto kompetentnosti. Priebeh vzdelávacích a profesijných dráh stráca svoju kontinuitu. Rozhodovat' sa musíme celoživotne a v každej životnej situácii, pretože istoty sa, ako sme už uviedli, vytratili. Politiky prispeli k novej, neoliberálnej, regulácii našich životov. Jedným z možných odôvodnení je tzv. teorém individualizácie, podla ktorého jednotlivci v stále väčšej miere môžu (musia) sami konštruovat' svoje vzdelávacie a profesijné dráhy. Kvôli narastajúcim globálnym prepojeniam sú ekonomiky náchylné na vonkajšie otrasy. Pracovné trhy tak od l'udí a od organizácií očakávajú vysokú schopnost' prispôsobit' sa. Ideálom sa stáva „podnikatel' so sebou samým“ (porov. termín entrepreneur, Bröckling, 2004, s. 55), ktorého hlavnou náplňou je čo najvýnosnejšie spravovat' svoj vlastný humánny kapitál.

Chápanie človeka ako suverénneho držitel'a humánneho kapitálu však maskuje jeho premenu na čo možno najlacnejší a l'ahko použitel'ný zdroj pre súkromné firmy a pre skutočný kapitál, ktorý sa ako jediný zhodnocuje slobodne. V tejto súvislosti zohrávajú významnú rolu všadeprítomné procedúry evalvácie, ktoré slúžia ako vysoko prepracovaný nástroj disciplinovania "slobodnej“ vol'by indivíduí. Inak povedané: je potrebné, aby ich vol'ba zodpovedala záujmom firiem či štátu. Prudký nárast praktík evalvácie vedie k internalizácii mechanizmov kontroly, teda k dohl'adu človeka nad sebou samým (porov. Keller, 2011, s. 71-72) k jeho sebariadeniu.

Súčasnú neoliberálnu éru je možné označit' ako prechod od záruk sociálneho štátu $\mathrm{k}$ zodpovednosti za seba samého a $\mathrm{k}$ individuálnemu rizikovému manažmentu. Tento kontext preto umožňuje nový pohl'ad aj na koncept celoživotného učenia vrátane vzdelávania a učenia sa dospelých. Už spomenuté sebariadenie a z neho vyvodená koncepcia sebariadeného učenia, sa ukazujú ako riadiaca technológia štátu a vzdelávanie dospelých ako súčast's tým súvisiacej moci.

O poradenstve sa $\mathrm{v}$ andragogike, ako vo vede o vzdelávaní a učení sa dospelých, diskutuje od 60-tych rokov 20. storočia (platí pre západoeurópsky priestor). Súčasné andragogické diskusie sa sústred'ujú hlavne na formy učebného poradenstva a poradenstva vo vzdelávaní dospelých. Poradenstvo je vždy závislé od kontextu, čo znamená, že musí zohl'adňovat' pluralitu teoretických prístupov a potrieb dospelých.

V problematike andragogického poradenstva je dôležité objasnit' a správne uplatňovat' pozície, na ktorých je založený koncept celoživotného učenia, celoživotného poradenstva a edukačného poradenstva (Pavlov, 2020). Práve edukačné poradenstvo patrí $\mathrm{k}$ jednému z mnohých druhov poradenských služieb poskytovaných aj dospelým (napríklad sociálne, personálne, kariérové, finančné, zdravotnícke a iné).

Edukačné poradenstvo pôvodne vzniklo pre potreby školskej praxe. Dnes sa skôr zameriava na pomoc jednotlivcom a skupinám $v$ ich študijnom, pracovnom a osobnom živote, pri zvyšovaní kvality ich života v sociálnej, duševnej, vzt’ahovej a výkonovej oblasti. Toto chápanie naznačuje perspektívu biodromálnych, edukatívno-formatívnych a rozvíjajúcich aspektov poradenstva a prístupu k osobnosti (porov. Sejčová in Švec a kol. 2015, s. 1235-1244).

Teoretici andragogiky vnímajú potrebu konceptualizácie tejto problematiky a sebe vlastnými prístupmi prispievajú $\mathrm{k}$ jej naplneniu (od deklaratívneho vymedzenia ako súčasti andragogického pôsobenia, cez pokusy o interdisciplinárne uchopenie inšpirované hlavne psychologickým poradenstvom až po formulovanie fundamentálnej otázky, v čom je andragogické poradenstvo iné, $v$ čom tkvie jeho podstata a účel). (Machalová, 2008, s. 65).

Andragogické poradenstvo je podla Machalovej (2017) poradenským vedením (usmerňovaním) ludí, aby sa rozhodli vzdelávat', zotrvali vo vzdelávacom procese, učili sa ako sa učit' a aby dokázali aplikovat' výsledky svojho vzdelávania - vedomosti, zručnosti a spôsobilosti v dôležitých oblastiach svojho života a v rámci profesionálneho 
a sociálneho rozvoja. $\mathrm{V}$ praxi sa andragogické poradenstvo môže uplatnit' v týchto oblastiach:

- $\quad$ oblasti profesijného života dospelých (andragogické poradenstvo $\mathrm{v}$ prieniku s profesijným poradenstvom - týka sa vol'by, udržania a zmeny povolania a zamestnania).

- V oblasti sociálnych podmienok a situácií života dospelých (andragogické poradenstvo $v$ prieniku so sociálnym poradenstvom a sociálnou prácou, edukačným sociálnym poradenstvom a edukačnou sociálnou prácou).

- $\quad$ oblasti kultúrno-záujmovej realizácie dospelých (andragogické poradenstvo v prieniku s kultúrno-osvetovou prácou).

Mayer (2017, s. 15) analýzou viacerých prístupov navrhuje, aby „ciel'om andragogického poradenstva bola identifikácia problému, vzdelávacích potrieb a individuálneho potenciálu jedinca, ak je možná intervencia edukáciou, resp. facilitácia pri vzdelávaní a učení sa, za účelom eliminácie problému, osobnostného rozvoja jedinca, saturácie jeho potrieb a záujmov a $v$ konečnej fáze aj vplyvu na kvalitu jeho života. To znamená poradenstva pri vzdelávaní, vol'be povolania, výbere zamestnania, kvalifikácii, rekvalifikácii, osobnostnom raste“. Podla Oravcovej (2013 s. 67-69) je poradenské pôsobenie na človeka interdisciplinárne a v realite nie je možné celkom presne oddelit' od seba jednotlivé druhy poradenskej práce, ktoré sa opierajú o viacero vedných disciplín. Poznatky uplatňované $v$ andragogickom pôsobení vychádzajú z poznatkov psychológie dospelého a tiež, že andragogické (a v zásade aj d'alšie špecializácie poradenstva) vychádzajú a opierajú sa o poradenstvo, ktoré má základ v psychologickom kontexte - teórii psychologického poradenstva, hoci využívajú k výkonu svojho poradenstva vlastné, špecifické prostriedky. Každá veda a k nej sa viažuce poradenstvo si má vymedzit' hranice svojho pôsobenia (napríklad pôsobenie poradcu, ked'že efektivita jeho činnosti sa odvíja od jeho vzdelania určujúceho hranice jeho kompetencií vo vzt'ahu k typu problému a typu klienta). Pri vymedzovaní zamerania andragogického poradenstva je, podl'a názoru Oravcovej nevyhnutné zachovat' odbornú líniu pomáhania v situáciách, s ktorými sa dospelý človek v živote stretne, kedy je intervenciou výchovy a vzdelávania možné uplatnit' pomoc človeku.

Podl'a nášho názoru má každé poradenstvo vo svojej podstate (vo väčšej či menšej miere) obsiahnuté prvky uvedomelých i neuvedomelých procesov učenia sa klientov. Ale len $v$ andragogickom poradenstve je učenie sa v celej jeho šírke, vrátane jeho kvality, hlavným účelom a ciel'om poradenskej intervencie.

\section{Návrh modelu andragogického poradenstva}

Zohl'adňujúc všetky vyššie uvedené argumenty v prospech potreby d'alšieho rozvoja a poskytovania andragogického poradenstva ako účinného nástroja rozvoja a zvyšovania účasti dospelých na d’alšom vzdelávaní, ako aj rešpektujúc jeho význačné črty a požiadavky naň kladené, sme dospeli $k$ vlastnému návrhu, presnejšie modelu andragogického poradenstva.

Andragogické poradenstvo považujeme za vysoko efektívny nástroj rozvoja docility dospelého človeka, t. j. jeho na neuroplasticite založenej schopnosti učit' sa. Bez docility by bolo každé formatívne (intencionálne a funkcionálne) pôsobenie na dospelého človeka, vrátane jeho autoformatívnych snáh, s ciel'om dosiahnut' pozitívne osobnostné zmeny, úplne márne. Možnost' zlepšovat' docilitu dospelého človeka odvodzujeme z tzv. bio-psycho-sociálneho modelu človeka. Predpokladáme, že zmeny plasticity mozgu, ktorá je základom učenia sa a všetkých duševných funkcií človeka majú priamy vplyv na efektívnost' vzdelávacích, terapeutických a všetkých ostatných aktivít, ktoré sú čast'ou sociálneho pol'a. Zároveň (mysliac na zámerné zlepšovanie docility) predpokladáme, že to platí i naopak. 
Andragogické poradenstvo je službou edukačného charakteru poskytovanou dospelým jednotlivcom, skupinám a organizáciám s ciel'om transformovat' ich problémy na problémy riešitel'né učením - to zakladá univerzálnost' andragogického poradenstva v orientácii na rôzne témy a ciel'ové skupiny. „Je zrejmé“, ako uvádza Beneš (2014, s. $18)$, „že nie všetky životné problémy sú nutne zvládnutel'né pomocou učenia. Niektoré sa dajú odstránit' napr. peniazmi alebo inými zdrojmi, právne, mocensky, technologicky. Niektoré problémy môže človek delegovat', napr. zdravotné na lekársku starostlivost'. Vlastné učenie ale človek delegovat' nemôže, nikto sa nemôže učit' za niekoho. (...) Andragogickou úlohou pri učení je podla potreby pomáhat'. Človek sa vždy učí niečo, učenie je odkázané na témy. Aj oblúbená požiadavka, že človek má učit' sa učit', predpokladá nejaké obsahy. Andragogika sa potom zameriava na vytvorenie komunikácie podporujúcej učenie a na vzt’ah medzi témami a učením. Úlohou andragogiky je teda hl'adat' formy a metódy umožňujúce a podnecujúce učenie sa dospelého. (...) Učenie, témy, komunikácia a hl'adanie ciest a metód, ako žiadané procesy učenie zaistit', tvorí v andragogike jeden celok, ktorý umožňuje i autonómiu andragogiky a možnost' rozlíšení od ostatných sociálnych vied (...).“

Model andragogického poradenstva vníma poradensky proces ako učenie, ktoré je $\checkmark$ prípade dospelých jednotlivcov:

- Zmysluplné - poradenské obsahy musia dospelým dávat' zmysel, zodpovedat' ich životným skúsenostiam.

- $\quad$ Nelineárne - problémy dospelých nevyvstávajú z oblasti formálnej logiky, kde je riešenie bud' správne, alebo nesprávne (tertium non datur), ale priamo z bežného života, v ktorom vždy treba zohl'adnit' viacero perspektív. Pokial' sa človek už (napríklad vplyvom poradenstva) konečne rozhodol, môže sa jednoducho stat', že toto rozhodnutie je neužitočné a celú situáciu je nútený nanovo prehodnotit'.

- Sebakritické - sebakritické spochybnenie je pre učenie sa absolútnou nutnost'ou. Človek sa môže pýtat': Čo som sa naučil? Na čom sa to zakladá? Akým spôsobom bolo preukázané (napríklad poradcom), že je to tak a že boli zohl'adnené všetky perspektívy? Zároveň to znamená, že sa neuplatňuje iba jedna, ale viaceré stratégie učenia.

- Transformatívne: umožňuje človeku zamysliet' sa nad vlastnými zvyklost'ami, predpokladmi a spôsobmi myslenia, ktoré si počas života vytvoril a ked' je to potrebné, aj nanovo prehodnotit'. Spôsoby, akými človek uvažuje, vyplývajú z jeho biografie, kultúry, v ktorej žije, či regióne, v ktorom vyrastal. Schopnost' vydat' sa novým smerom je dôsledkom transformatívneho učenia.

V tejto súvislosti treba pripomenút', že poradenský proces musí tiež prihliadat' na piliere, na ktorých sa učenie dospelých l'udí zakladá:

- získavanie informácií,

- reflektovanie informácií: „Akú asociáciu viem s touto informáciou spojit??,

- hl'adanie relevantnosti: „V čom spočíva význam? Ako viem túto novú informáciu integrovat' do mojich existujúcich vedomostí?" V tomto kroku teda pracuje so svojimi spomienkami, aplikuje ich však na súčasnú situáciu a pýta sa, ako to celé vie zosúladit'. Z toto vyvstáva akýsi druh teórie: „Čo pre mňa znamená táto informácia?",

- $\quad$ test reality: „Do akej miery zodpovedá táto teória realite?“.

$V$ prípade organizácií ide $v$ andragogickom poradenstve najmä o hl'adanie odpovedí na otázku, ako sa z organizácií stavajú „učiace sa organizácie“, „kde l'udia trvalo zvyšujú svoju schopnost' prinášat' výsledky, kde pestujú nové a expanzívne spôsoby myslenia, kde sa kolektívnej snahe nekladú medze a l'udia sa ustavične učia vidiet' veci ako celok" (Senge, 1990 in Russell-Walling, 2012, s. 116). 


\section{Funkcie andragogického poradenstva}

1. Edukačná: analýza rôznych algoritmov autoregulačných a metakognitívnych stratégií dospelých s ciel'om zistit', ktoré z nich umožňujú efektívne spracovávane a aplikovanie získaných poznatkov. Prostredníctvom slovnej intervencie sa poradca stáva tým, kto zámerným navodzovaním nerovnovážneho stavu v kognitívnej oblasti (disonancia/perturbácia) iniciuje u dospelého človeka vedomý proces zmien v jeho doterajších schémach konania a myslenia (akomodácia). (porov. Glasersfeld, 1995)

2. Podporno-preventívna: utvorenie jasne vymedzeného času a priestoru na konceptualizáciu a (re)štrukturáciu informácií získavaných životnými skúsenost'ami, prácou, vzdelávaním a d’alšími informačnými zdrojmi (napríklad virtuálny priestor). Podporná funkcia spočíva v utvorení učenie podporujúcej poradenskej klímy.

3. Podporno-sebareflexívna: podpora kompetentnosti konat' zodpovedne voči sebe samému a voči prostrediu. Podpora, funkčných a koexistenciu podporujúcich interpersonálnych vzt'ahov.

4. Podporno-organizačná: funkcia „aranžovania“ učebného prostredia vo vzt’ahu k organizácii spočíva v utváraní podmienok umožňujúcich učenie a samostatné konanie (napríklad na pracovisku), konkrétne ide o formulovanie a uplatnenie pravidiel (vrátane učebných aranžmánov, porov. Dehnbostel, 2008) určujúcich podmienky individuálneho, tímového a organizačného rozvoja.

5. Etická funkcia: andragogické poradenstvo, rovnako ako každý iný druh poradenstva, je zakaždým aj morálnou praxou. Ide predsa o záležitosti človeka, jeho bytia a dôstojnosti. Vzdelávacie a socializačné úsilie andragógov vystupujúcich $v$ roli poradcov treba chápat' ako súčast' úsilia o dobrý život. Napokon, „(...) andragogický expertný prístup“ plní podl'a Fobela (2017, s. 10), „etickú funkciu, podiel'a sa na normatívnej spoločenskej úlohe a využíva vlastný profesionálny i odborný potenciál na podporu humanity."

Konštituovanie etiky andragogického profesijného poradenstva ako súčasti andragogickej etiky (Pavlov-Schubert, 2015, 2016) má potenciál posilnit' nasledujúce dimenzie:

- inštitucionálnu dimenziu (etika poskytovatel'a poradenských služieb a jeho podnikanie v poradenstve, etika obchodu s poradenskými službami),

- procesuálnu dimenziu (etika poradenstva, etické aspekty tvorby programov, ciel'ov, metód, foriem a prostriedkov poradenstva),

- personálnu dimenziu (etické normy v práci andragóga - poradcu, jeho etický kódex, osobnostná integrita).

Andragogické profesijné poradenstvo zohl'adňuje:

- Prvky preukázatel'ne efektívnych teoretických koncepcií, ako napríklad novšia teória systémov, konštruktivizmus, či pragmatizmus, ktoré umožňujú riešit' problémy na jednotlivca a organizácie (napríklad Patton, McMahon, 2006; Ludewig, 2011; Savickas, 2012; Dehnbostel, 2015). Model zároveň nadväzuje na existujúce teoretické koncepty andragogického poradenstva rozvíjané v SR (napríklad Oravcová, 2012, 2013).

- Novšie neurovedné zistenia (cognitive neuroscience) (napríklad Koukolík, 2014; Spitzer, 2006, 2015; Spizter, Herschkowitz, 2020), ktoré andragogike poskytujú východiská potrebné pre teoretický rozvoj poznania docility dospelých.

- Paradigmatickú líniu poradenstva pre dospelých, ktorá nahrádza ponímanie poradenstva ako výrazu deficitu, ponímaním poradenstva ako integrálnej súčasti celoživotného učenia (pomoc k svojpomoci); 
- Komplexnost' vzdelávacej a učebnej podpory klientov: poradenstvo rozširuje učebný priestor jednotlivca o d'alšiu dimenziu, v rámci ktorej bude podnecovaný k spracúvaniu informácií získaných vzdelávaním a v priebehu života. Poradenstvo nie je len o získavaní nových vedomostí, ale aj o utvrdzovaní, overovaní a modifikovaní existujúcich interpretácií životnej reality dospelého človeka (porov. Arnold, Siebert, 2006, s. 5-6).

- Individuálny prístup (kontrakt) bez striktnej štandardizácie priebehu (dĺžky a frekvencie poradenskej podpory), ktorá je predpokladom variantného využitia a individuálneho nastavenia (od jednorazových po dlhodobé kontrakty), smerujúceho k zvýšeniu individuálnej integrity, reflektívnosti a samostatnosti dospelých;

- Holistický prístup v zmysle sprevádzania v profesijnom rozvoji, so zohl'adnením biografie jednotlivca, jeho aktuálnych životných situácií a profesijných potrieb.

\section{Osobitosti andragogického poradenstva}

Andragogické poradenstvo sa musí zakladat' na systematickej, viacnásobne reflexívnej a samostatnost' zdôrazňujúcej analýze vlastných a cudzích interpretácií samotným dospelým aj poradcom. Poradenský program umožňuje artikuláciu existujúcich konštruktov skutočnosti, ich vzájomné porovnanie, overenie ich udržatel'nosti vzhl'adom na nové situácie a ich d'alší rozvoj. Andragogické poradenstvo nie je len o nadobúdaní nových vedomostí, ale aj o utvrdzovaní, overovaní a modifikovaní existujúcich interpretácií. Úlohou andragogického poradenstva je podporovat' reflexiu interpretácií a otvorenost' voči „reinterpretáciám“, t. j. voči novým pohl'adom“ (upravené podl'a. ArnoldSiebert, 2006, s. 5-6). Na tento účel sa andragógom vystupujúcim v roli poradcu ponúka ako účinný nástroj najmä rozhovor. Svet skúseností tak poradcu ako aj prijímatel'a poradenstva je plný iných ludí a takmer nepretržitá interakcia s nimi je bohatým zdrojom perturbácií (zmeny stavu v štruktúre nejakého systému, ktoré spustili, nie spôsobili zmeny $v$ ich prostredí) a následných akomodácií. Jean Piaget často zdôrazňoval, že najčastejšou príčinou akomodácie je interakcia s l'ud'mi, obzvlášt' tá jazyková.

\section{Profesijné kompetencie poradcov}

$\checkmark$ praxi andragogického poradenstva zohráva ústrednú úlohu poradca, a to aj napriek tomu, že v súčasnosti sa zodpovednost' za rozvoj presúva čoraz viac na indivíduum. Kompetencie a zodpovednost' poradcu sú ohraničené procesom (práca s problémom klienta v poradenskom vzt'ahu) a zodpovednost'ou vo vzt'ahu ku klientovi (nie za klienta). Za rozhodnutia a učebné zmeny zodpovedá dospelý klient.

Štruktúru profesijných kompetencií poradcu je možné opísat' na základe modelu založenom na tzv. bázických kompetenciách (porov. Dehnbostel, 2008; Münch, 2003; Pahl, 2010) nasledovne:

- Odborná kompetentnost' poradcu predstavuje spôsobilost' ciel'avedome, primerane, metodicky správne a samostatne riešit' úlohy a problémy ako aj posúdit' výsledok.

- Metodická kompetentnost' označuje spôsobilost' ciel'avedomého, plánovitého postupu pri spracovávaní úloh a problémov, napr. plánovanie jednotlivých pracovných operácií.

- Sociálna kompetentnost' označuje spôsobilost' vnímat' a chápat' sociálne vzt'ahy a záujmy, byt' zodpovedným vo vzt'ahu k iným a vychádzat' s nimi, pracovat' $v$ tíme a kooperatívne riešit' problémy. Ide teda najmä o sociálnu zodpovednost' a primeranú solidaritu.

- Osobná kompetentnost' označuje spôsobilost' reflektovat' vlastný rozvoj a d'alej sa rozvíjat' v súlade s individuálnymi a spoločenskými hodnotovými predstavami. 
Zahŕňa vlastnosti ako samostatnost', schopnost' prijímat' kritiku, sebadôveru, spol'ahlivost', zmysel pre zodpovednost' a povinnost'.

\section{Záver}

Andragogické poradenstvo ako integrálna súčast' edukačného poradenstva je službou edukačného charakteru poskytovanou dospelým jednotlivcom, skupinám a organizáciám s ciel'om transformovat' ich problémy na problémy riešitel'né učením - to zakladá univerzálnost' andragogického poradenstva v orientácii na rôzne témy a ciel'ové skupiny. $\checkmark$ rovine výsledkov má tento druh andragogického pôsobenia nielen rozvojový, ale aj preventívny a stabilizačný potenciál.

V súvislosti súvahami o andragogickom poradenstve považujeme za potrebné zdôraznit', že v žiadnom príde nejde o pokus nahrádzat' akýkol'vek iný typ poradenstva poskytovaného dospelým jednotlivcom a skupinám, ako napríklad zdravotné psychologické, sociálne, finančné či filozofické poradenstvo. Z toho zároveň vyplývajú určité obmedzenia andragogického poradenstva. Andragóg disponuje výlučne edukačnými a nie napríklad zdravotníckymi a terapeutickými prostriedkami. Limitujúcimi faktormi andragogického poradenstva sú preto náležitý zdravotný stav, t. j. neprítomnost' závažných telesných a duševných porúch, dobrovol'nost', transparentnost' a časová obmedzenost' poradenského kontraktu. Posledné tri faktory sú klúčové aj pre poskytovanie andragogického poradenstva na úrovni tímov a organizácií.

\section{Pod'akovanie}

Práca je súčast'ou riešenia grantu KEGA MŠVVaŠ SR č. 015UMB-4/2019 „Rozvoj poradenských kompetencií študentov v študijnom odbore andragogika" na Katedre andragogiky Pedagogickej fakulty Univerzity Mateja Bela v Banskej Bystrici.

\section{Literatúra}

Arnold. R., Siebert, H. (2006). Konstruktivistische Erwachsenenbildung. Von der Deutung zur Konstruktion von Wirklichkeit. Baltmannsweiler: Scheider Verlag Hohengehren.

Beneš, M. (2014). Andragogika. 2. aktualiz. a rozšír. vyd. Praha: Grada.

Bröckling, U. 2004. Empowerment. In U. Bröckling, S. Krasmann, T. Lemke, Glossar der Gegenwart (s. 55-62). Frankfurt am Main: Suhrkamp.

Dehnbostel, P. (2008). Berufliche Bildung. Berlin: edition sigma.

Dehnbostel, P. (2015). Betriebliche Bildungsarbeit : Kompetenzbasierte Aus- und Weiterbildung im Betrieb. Baltmannsweiler: Schneider Verlag Hohengehren.

Európska komisia. (2000). Memorandum o celoživotnom vzdelávaní. Brusel: SEC(2000) 1832. Dostupné na

https://www.minedu.sk/data/files/2607 2000

memorandum o celozivotnom vzdelavani.pdf $>$.

Fobel, P. (2017). Etika ako aplikačná stratégia (metodické a teoretické odporúčania). In M. Schubert (ed.), Etické aspekty edukácie dospelých (9-18). Banská Bystrica: Belianum. Glasersfeld, E. von (1995). Aspekte einer konstruktivistischen Didaktik. Lehren und Lernen als konstruktive Tätigkeit. Soest: Regional Institute for school and secondary education, 7-14. Dostupné na http://www.vonglasersfeld.com/179

Keller, J. (2011). Nová sociální rizika. Praha: SLON.

Koukolík, F. (2014). Mozek a jeho duše. Praha: Galén.

Ludewig, K. (2011). Základy systemickej terapie. Praha: Grada Publishing.

Machalová, M. (2008). Andragogické asociálno-andragogické poradenstvo v kontexte celoživotného učenia sa a vzdeláva. In J. Matulčík (ed.), Acta Andragogica 1 (s. 63-70). Bratislava: Univerzita Komenského. 
Machalová, M. (2017). Psychológia a andragogika na pomoc dospelému človeku. In Prohuman. Dostupné na http://www. prohuman.sk/psychologia/psychologia-aandragogika-na-pomoc-dospelemu-cloveku

Mayer, K. (2017). Poradenstvo v andragogickom kontexte. Prešov: Prešovská univerzita. OECD. (2020). OECD Skills Strategy Slovak Republic: Assessment and Recommendations, OECD Skills Studies. Parsis: OECD Publishing. Dostupné na https://doi.org/10.1787/bb688e68-en

Oravcová, J. (2012). Pomáhajúce poradenstvo a jeho špecializácie. In P. Fobel a kol., Etika \& poradenstvo \& prax (35-57). Banská Bystrica: FHV UMB.

Oravcová, J. (2013). Poradenstvo pomáhajúcich profesií. Banská Bystrica: PF UMB.

Pahl, J. P. (2010). Fachschule. Praxis und Theorie einer beruflichen Weiterbildungseinrichtung. Bielefeld: W. Bertelsmann Verlag.

Patton, W., \& McMahon, M. (2006). The systems theory framework of career development and counseling: Connecting theory and practice. In International Journal for the Advancement of Counselling, 28 (2), 153-166.

Pavlov, I., Schubert, M. (2015). Konceptuálne rámce andragogickej etiky. In Andragogická revue, 7 (1), 18-30.

Pavlov, I., Schubert, M. (2016). Andragogická etika - diskurz o výchove, sebavýchove, ideáloch, hodnotách a normách. In I. Pavlov, M. Schubert (eds.), Etické kontexty andragogického pôsobenia (11-48). Banská Bystrica: Belianum.

Pavlov, I., Bontová, A., Schubert, M. (2016). Učitel'ská andragogika a model andragogického poradenstva. In J. Veteška (ed.), Vzdělávání dospělých - východiska a inspirace pro teorii a praxi (s. 165-175). Praha: Česká andragogická společnost.

Pavlov, I. (2020). Andragogické poradenstvo. Prešov: Rokus, s.r.o.

Rada EÚ. (2008). Návrh uznesenia Rady a zástupcov vlád členských štátov, ktorí sa zišli na zasadnutí Radyz 21. novembra 2008-,Lepšie začlenenie poradenstva do stratégií celoživotného vzdelávania“. Dostupné na

https://eur-lex.europa.eu/legal-

content/SK/TXT/PDF/?uri=CELEX:42008X1213(02)\&from=SK

Rada EÚ. (2018). Odporúčanie Rady z 22. mája 2018 o kl'účových kompetenciách pre celoživotné vzdelávanie. Dostupné na

https://eur-lex.europa.eu/legal-

content/SK/TXT/PDF/?uri=CELEX:32018H0604(01)\&from=EN

Russell-Walling, E. (2012). Manažment 50 myšlienok, ktoré by ste mali poznat'. Bratislava: SLOVART.

Savickas, M. L. (2012). Life design: A paradigm for career intervention in the 21st century. In Journal of Counseling \& Development, 90 (1), 13-19.

Sejčová, L'. (2015). Náuka o edukačnom poradenstve. In Š. Švec (ed.), Slovenská encyklopédia edukológie (s. 1235-1244). Bratislava: Univerzita Komenského.

Spitzer, M. (2006). Lernen : Gehirnforschung und die Schule des Lebens. Heidelberg: Spektrum.

Spitzer, M. (2015). Denken - zu Risiken und Nebenwirkungen. Stuttgart: Schattauer.

Spitzer, M., Herschkowitz, N. (2020). Wie wir denken und lernen: Ein faszinierender Einblick in das Gehirn von Erwachsenen. München: mvg Verlag.

\section{Adresy autorov}

\section{Prof. PaedDr. Ivan Pavlov, PhD.}

Katedra andragogiky, Pedagogická fakulta, UMB v Banskej Bystrici

Ružová 13, 974 11, Banská Bystrica 
ivan.pavlov@umb.sk

Mgr. Martin Schubert, PhD.

Katedra andragogiky, Pedagogická fakulta, UMB v Banskej Bystrici Ružová 13, 974 11, Banská Bystrica

martin.schubert@umb.sk 


\title{
REFLEXIA VYUČOVACÍCH VÝSTUPOV ŠTUDENTA UČITEL'STVA NA PEDAGOGICKEJ PRAXI
}

\section{THE REFLECTION OF TEACHER STUDENT'S TEACHING OUTPUTS IN PEDAGOGICAL PRACTICE}

\author{
Katarína Petríková \\ Katedra pedagogiky, Filozofická fakulta, UPJŠ v Košiciach \\ Renáta Orosová \\ Katedra pedagogiky, Filozofická fakulta, UPJŠ v Košiciach \\ Michal Novocký \\ Katedra pedagogiky, Filozofická fakulta, UPJŠ v Košiciach
}

\begin{abstract}
:
The preparation for the teaching profession includes a theoretical and a practical part. Acquisition and development of professional competencies of teacher students through the connection practical experience with theoretical knowledge with the active participation of the mentor teacher is the main goal of pedagogical practice. Mentor teachers are an important part of the undergraduate preparation of teacher students, their process of becoming a teacher. Their role is to evaluate and analyse students' learning and teaching and to consider how these processes can be improved. They direct the student to reflect on their own activity and self-reflection in order to effective the education. In the paper, the authors present partial results of the research realised within the VVGS project "Diagnostic competence of a mentor teacher as a reflexive practitioner". The paper presents the opinions of mentor teachers on the level of teaching outputs of UPJŠ teacher student at pedagogical practice, based on competencies oriented on student, the educational process and professional development (selfdevelopment) of the teacher.
\end{abstract}

Key words:

reflection, teacher student, mentor teacher, pedagogical practice

\section{Úvod}

$\mathrm{Na}$ adresu učitel'skej profesie bolo medzi odbornou, ale aj širokou verejnost'ou vyslovených už množstvo názorov a výrokov, a to od tých, ktoré vysoko oceňujú toto povolanie, až po kritické či odsudzujúce slová. V súčasnosti azda neexistuje profesia, ktorá by mala tol'ko obdivovatel'ov aj kritikov zároveň (Petríková \& Orosová, 2018). Učitel'stvo patrí historicky medzi najstaršie povolania a i napriek všetkým pokusom o inovácie $v$ školstve, zameraným na nahradenie učitel'a $v$ rôznych moderných koncepciách vyučovania využívajúcich výdobytky rýchlo sa rozvíjajúcich informačnokomunikačných technológií, zohráva učitel' aj nad’alej rozhodujúcu úlohu vo vyučovacom procese a ako taký je nielen sprostredkovatel'om vedomostí, ale rovnako aj kultúrnych tradícií a spoločenských hodnôt (Rovňanová, 2015). Hoci mnohé publikácie zaoberajúce sa problematikou učitel'a poskytujú rôzne definície tohto pojmu, môžeme povedat', že úlohou učitel'a je vytvárat' prostredie, v ktorom sa bude diet’a rozvíjat' ako individuálna 
osobnost', podnecovat' rozvoj jeho poznávacích procesov a tiež stimulovat' rozvoj personálnych a interpersonálnych kompetencií dôležitých pre jeho život.

Svetová pedagogika vníma učitel'a ako experta na stretávanie sa učitel'a a žiaka prostredníctvom učiva, na ulahčovanie procesu učenia či riešenie školských edukačných situácií (Coolahan, Vonk, Shulman, Hustler, Intyre, Perrenoud, Berliner a i. In Spilková, 2004). Do popredia sa teda dostáva nielen otázka kvality školy, ale aj kvality učitela, ktorá je všeobecne považovaná za klúčový faktor ovplyvňujúci zásadným spôsobom kvalitu školského vzdelávania (Crone \& Teddlie, 1995). Zvyšovanie kvality učitel'ov a skvalitňovanie systému ich prípravy a d’alšieho rozvoja je v súčasnosti považované za klúčový nástroj vzdelávacích reforiem a inovácií v činnosti škôl. Inovácie, ktoré v ostatnej dobe zasiahli školský systém z hl'adiska prístupov, či metód a foriem, je preto potrebné aplikovat' už v rámci pregraduálnej prípravy (Orosová et al., 2018). Ciel'om pregraduálnej prípravy je, okrem iného, vštepovat' študentom schopnost' robit' pedagogické rozhodnutia založené na racionálnej argumentácii. Aby však mohol študent objektívne nazerat' na svoje konanie $v$ edukačnom procese, je potrebné viest' ho systematicky ku kvalitnej reflexii svojho konania a k jeho objektívnemu hodnoteniu, čo môžeme vidiet' v práci všeobecných a predmetových didaktikov $v$ univerzitných podmienkach a v práci cvičných učitel'ov v rámci pedagogickej praxe študentov (Orosová et al., 2018).

\section{Pedagogická prax $\mathbf{v}$ pregraduálnej príprave študentov učitel'stva}

Pregraduálna príprava, ako komplexné štúdium na vysokej škole, je dôležitou zložkou profesijného rozvoja budúcich učitel'ov, ktorej ciel'om je formovanie študentov po ich osobnostnej a profesionálnej stránke, čo je zároveň jedna z klúčových fáz, v ktorej rola študenta postupne prechádza do roly učitel'a (Orosová, Petríková \& Diheneščíková, 2018). Pregraduálna príprava má teoretický a praktický charakter. Kým však teoretická príprava je zameraná na získavanie a rozvoj vedomostí, zručností a spôsobilostí v oblasti pedagogiky, psychológie a vo vedných odboroch vyučovacích predmetov, praktická profesijná príprava je orientovaná na prípravu na výkon samotného povolania a mala by tvorit' značnú čast' obsahu študijných plánov učitel'stva, pretože študenti v rámci nej rozvíjajú svoje schopnosti a profesijné kompetencie nevyhnutné na vykonávanie učitel'skej profesie (Orosová, 2017).

Neoddelitel'nou súčast'ou pregraduálnej prípravy študentov učitel'stva je teda ich participácia na pedagogickej praxi. Pedagogickú prax možno chápat’ ako aktivizujúci a motivačný činitel' $v$ procese pregraduálnej prípravy, ako sebarealizačný činitel' na odhalenie individuálnych osobitostí a zároveň ako prostredie vhodné pre aplikáciu teoretického vzdelania, v ktorom sa rozvíja vzt’ah $\mathrm{k}$ žiakom, k budúcim kolegom a $\mathrm{k}$ učitel'skej profesii (Čeliňák, 2007). Kosová, Tomengová et al. (2015) charakterizujú pedagogickú prax ako prípravu študentov učitel'stva na vyučovanie a každodenný život školy prostredníctvom praktického tréningu, teda praktického vyskúšania si stratégií, metód, techník vyučovania, riadenia triedy, práce so žiakmi a rôznych d'alších aktivít súvisiacich s učitel'skou profesiou. Účelom pedagogickej praxe je podla nej vytvorit' pre študentov učitel'stva podmienky pre získavanie a rozvoj profesijných kompetencií. Pedagogická prax má umožnit' poznanie reálnych modelov vyučovania, výchovy a každodenného života školy, hlbšie porozumenie žiakom, procesom ich učenia sa a budovanie vzt'ahov k nim, vytváranie základov profesijných spôsobilostí, zodpovednosti a správania sa, získanie odbornej spätnej väzby o vlastnej vyučovacej činnosti, sebareflexiu a vytvorenie d'alších predpokladov profesijného zlepšovania sa, získanie skúseností s komunikáciou s profesijnou komunitou a rodičovskou verejnost'ou a overenie si svojho potenciálu pre výkon učitel'skej profesie. Podla Daneka (2005) má pedagogická prax plnit' tri dôležité úlohy, a to poznávanie školy zo strany študenta; odstránenie obáv i trémy z pedagogickej komunikácie so žiakmi a konfrontáciu poznatkov získaných počas štúdia na fakulte s realitou školského života. V rámci pedagogickej 
praxe ide teda o modelový nácvik učitel'ských kompetencií na fakulte a poznávanie a pozorovanie školskej reality, asistenčné činnosti, vyučovanie pod vedením cvičného učitel'a s následnou spätnou väzbou a sebareflexiou v cvičných školách (Orosová, 2017). Na základe uvedeného môžeme konštatovat', že pedagogická prax pomáha budúcemu učitel'ovi pochopit' samotnú rolu učitel'a, identifikovat' sa s ňou, posilňuje jeho schopnost' učit' sa z praxe a nadobudnút' základnú zručnost' či poslanie učitel'a - pomáhat' žiakom učit'sa.

\section{Reflexia ako súčast' pedagogickej praxe}

Durozoi a Roussel (In Kosová \& Tomengová et al., 2015, s. 13) definujú reflexiu ako „akt, ktorým sa myslenie vracia k sebe samému hlavne preto, aby prehíbilo svoje analýzy“.

Pri reflexii človek teoretizuje svoje praktické postupy, teda racionalizuje a verbalizuje implicitné, intuitívne, skryté predpoklady svojho rozhodovania a konania. Rekonštruuje skúsenosti tým, že ich popisuje, prevádza do jazyka, do podoby procedurálnych poznatkov, aby ich pochopil, nabudúce predvídal alebo zmenil. Neuvedomované schémy konania sa v reči vydelia z činnosti samotnej a sú k dispozícii ako poznanie skúsených praktikov (Kasáčová, 2005). Ako uvádzajú Kosová, Tomengová et al. (2015), schopnost' reflexie vlastnej činnosti je zásadnou spôsobilost'ou učitel'ov. Je to kompetencia $k$ osobnému rastu, kompetencia $\mathrm{k}$ sebarozvoju a sebazdokonal'ovaniu profesionála $\mathrm{v}$ edukácii. To najcennejšie, čo môže dat' uvádzajúci učitel' začínajúcemu učitel'ovi alebo vysokoškolský, či cvičný učitel' študentovi na celý profesionálny život, je nástroj pre neustálu rekonštrukciu vlastnej edukačnej teórie - čiže podporit' rozvoj jeho schopností odborne hodnotit' svoju vyučovaciu činnost', tým inovovat' svoje pedagogické názory a neustále zlepšovat' svoje učitel'ské schopnosti.

Myšlienka, že pedagogické majstrovstvo učitel'a a jeho zvyšujúca sa expertnost' sú založené na schopnosti učitel'a reflektovat' vlastnú prax je vo svete všeobecne uznávaná, a to bez ohl'adu na koncepty a prístupy, z ktorých koncepcie prípravy učitel'ov vychádzajú (Kosová, 2016). Výskumne overená teória vzájomného vzt'ahu teoretického a praktického poznania dokazuje, že podmienkou ich prepojenia a postupnej premeny študentovho profesijného konania a profesijného myslenia je reflexívny charakter pedagogickej praxe, ktorý vychádza zo sociokonštruktivistickej teórie poznania a učenia sa (Korthagen et al., 2011). Meniaci sa kontext školskej edukácie v posledných desat'ročiach prináša nové fakty a požiadavky do vnímania učitel'skej profesie. Viac sa zdôrazňuje posun od tradičného modelu tzv. minimálnej kompetencie, t.j. odovzdávania určeného obsahu žiakom, $\mathrm{k}$ modelu širokej profesionality, t.j. vzdelávaniu podla kompetencií, určovaniu ciel'ov edukačného procesu a tvorbe študijných programov založených na rozvíjaní kompetencií (Rovňanová, 2015). Tento model podla Korthagena (1992), Schöna (1987) a Lasleyho (1992) považuje učitel'a za základ zvyšovania kvality vzdelania, chápe ho ako sebarozvíjajúceho, reflexívneho praktika, ktorý sa prostredníctvom stálej reflexie učitel'skej činnosti mení z roly študenta na rolu učitel'a, experta na učenie sa a na rozvíjanie iných osôb. Do popredia sa tak dostáva pravidelná sebareflexia s ciel'om skvalitnenia vlastnej činnosti (Minor et al., 2002). Kompetencia reflektovat' vlastnú prax a výučbu, ktorá je považovaná za základnú kompetenciu k profesijnému rastu, je súčast'ou profesijných štandardov pre výkon učitel'skej profesie v mnohých krajinách (Spilková \& Tomková et al., 2010) a koncept reflexívnej praxe sa zároveň stáva najrozšírenejším modelom pre koncipovanie praktickej prípravy budúcich učitel'ov na vysokých školách.

Na základe uvedeného môžeme konštatovat', že v procese pregraduálnej prípravy a profesijného rozvoja budúceho učitel'a zohráva významnú úlohu reflektívny dialóg cvičného učitel'a a študenta, ktorý mu pomáha rozvíjat' profesijné znalosti študenta (Crasborn et al., 2010) a poskytovat' podporu jeho profesijnému rastu. Reflexia vyžaduje spôsobilosti späté so schopnost'ou spätného pohl'adu, nazretia do situácie a predvídania 
d’alšieho rozvoja. Ide o komplex vedomostí, zručností a d’alších charakteristík, ktoré je potrebné rozvíjat'. Niektorí cviční učitelia prirodzene dokážu reflektovat' a poskytnút' spätnú väzbu a podporu študentovi na praxi, iní potrebujú adekvátnu prípravu a podporu rozvoja ich reflexívnych spôsobilostí a reflexívnej praxe (Zachary, 2002). Táto podpora by mala byt' učitel'om poskytnutá najmä zo strany vysokých škôl pripravujúcich budúcich učitel'ov, a to nielen s ohl'adom na rozvoj a skvalitňovanie ich reflexívnych spôsobilostí, ale aj s dôrazom na podporu spolupráce a väčšej miery prepojenia vysokoškolskej, prevažne teoretickej, prípravy študenta s prípravou praktickou. Cviční učitelia, vedomí si významu a úloh profesijnej reflexie a jej devíz pre študentov učitel'stva, participujú na uplatňovaní a rozvíjaní realistického vzdelávania učitel'ov. Ich ciel'om nie je prioritne študenta hodnotit', ale analyzovat' jeho učenie a vyučovanie a uvažovat', akým spôsobom možno tieto procesy skvalitnit' (Duschinská, 2010). Hodnotia spôsobilosti študentov učitel'stva na základe ich samostatných pedagogických výstupov, pričom študenti majú zároveň možnost' sebahodnotenia, t. j. reflexie vlastnej činnosti.

\section{SWOT analýza reflexie vyučovacích výstupov študenta na praxi}

$\mathrm{Na}$ zistenie úrovne vyučovacích výstupov študenta učitel'stva na pedagogickej praxi sme použili SWOT analýzu.

Ciel' analýzy: Zistit' silné a slabé stránky, možnosti a ohrozenia vyučovacích výstupov študenta na pedagogickej praxi z pohl'adu cvičných učitel'ov ako reflexívnych praktikov.

Miesto realizácie analýzy: Analýzu sme uskutočnili v rámci workshopu „Cvičný učitel' ako diagnostik a reflexívny praktik" realizovaného pre cvičných učitel'ov.

Metóda analýzy: Na zistenie názorov cvičných učitel'ov na úroveň vyučovacích výstupov študenta učitel'stva na pedagogickej praxi sme použili metódu pozorovania, ktorú sme realizovali prostredníctvom záznamového hodnotiaceho hárku.

Respondenti: Analýzy sa zúčastnili cviční učitelia zo základných a stredných škôl v Košiciach, spolu 25 cvičných učitel'ov.

Tab.: 1 Výsledky SWOT analýzy

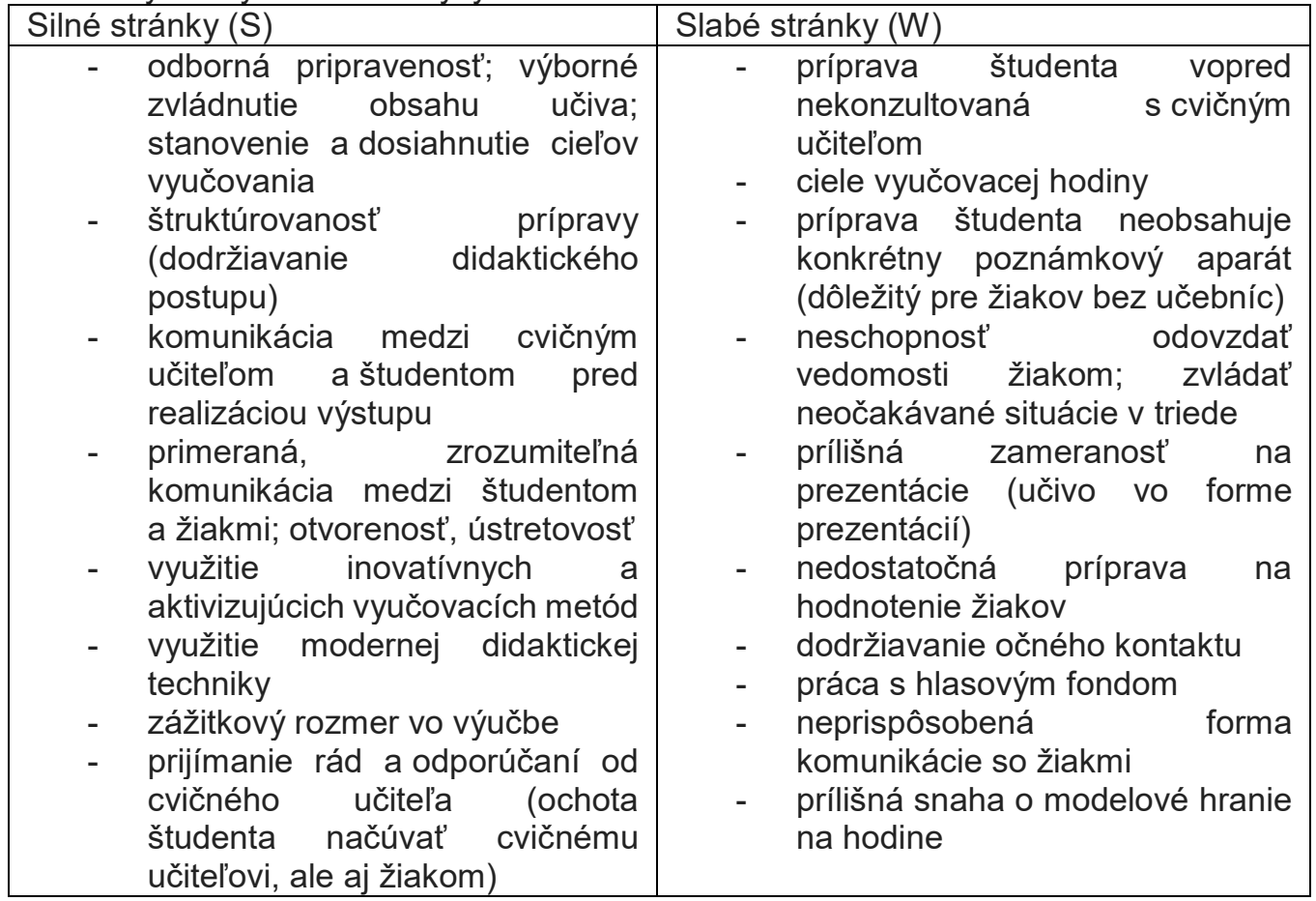




\begin{tabular}{|c|c|}
\hline $\begin{array}{ll}\text { - } & \text { inšpirácia od študentov pre } \\
& \text { cvičného učitel'a } \\
\text { - } & \text { vytvorenie priestoru pre kreativitu } \\
\text { študenta } \\
\text { - } \quad \text { reflexia otočenej hodiny } \\
\text { - } \quad \text { inšpirácia pre vlastnú prax }\end{array}$ & $\begin{array}{ll}\text { - } & \text { časové rozvrhnutie vyučovacej } \\
& \text { hodiny } \\
\text { - } & \text { strach, neistota študenta; stres } \\
\text { - } & \text { študent neprijíma odporúčania } \\
\text { cvičného učitel'a } \\
\text { - } \begin{array}{l}\text { neskorý kontakt študenta s } \\
\text { praxou }\end{array}\end{array}$ \\
\hline Príležitosti (O) & Ohrozenia $(T)$ \\
\hline 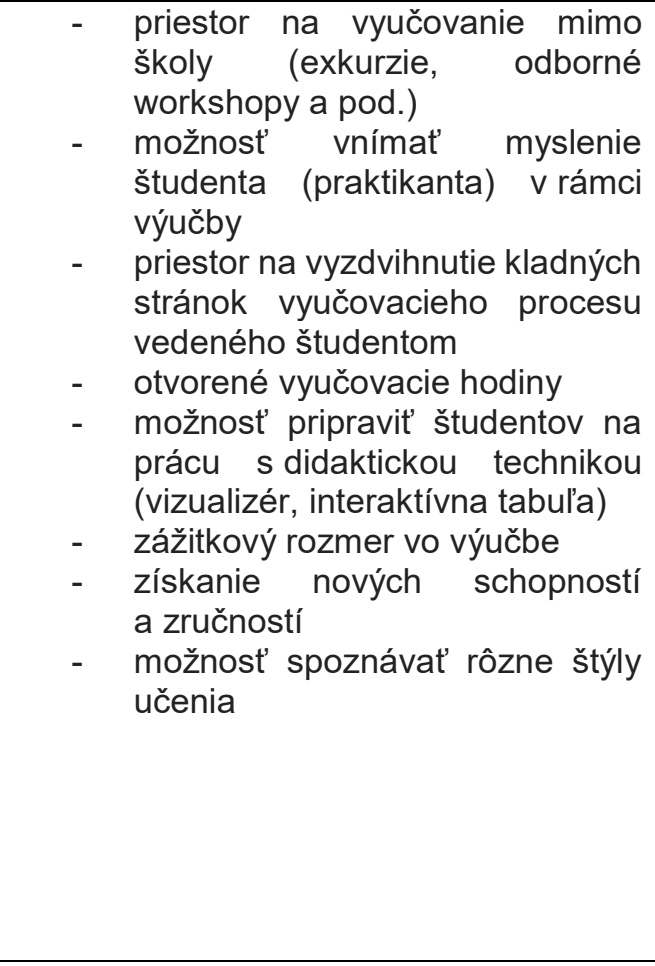 & 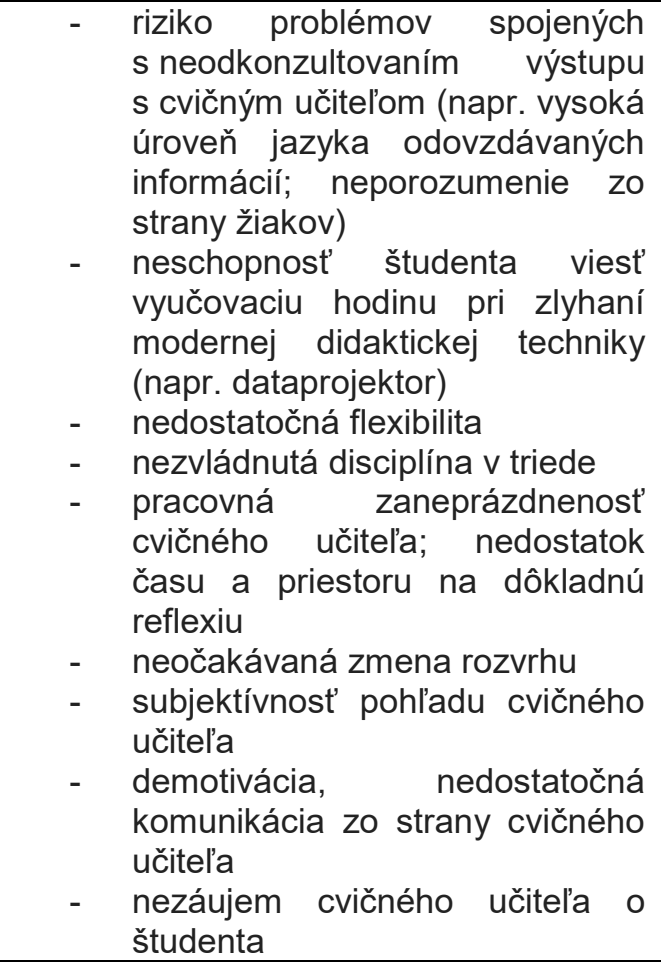 \\
\hline
\end{tabular}

(Zdroj: vlastné spracovanie)

\section{Návrhy a odporúčania vyplývajúce zo SWOT analýzy}

Na základe výsledkov získaných zo SWOT analýzy odporúčame pri realizácii samostatných výstupov študentov učitel'stva na pedagogickej praxi:

- dostatočne pripravit' študentov po didaktickej stránke;

- dostatočne pripravit' študentov po obsahovej a organizačnej stránke vyučovacej hodiny;

- pripravit' študentov v oblasti pedagogickej komunikácie (prejav, vystupovanie, interakcia študenta/praktikanta a žiaka, spôsoby zvládania kritických, neočakávaných situácií);

- zamerat' sa na individuálny prístup k integrovaným žiakom;

- zo strany cvičného učitel'a komunikovat' so študentom, poskytnút' mu spätnú väzbu, reflexiu s prvkami konštruktívnej kritiky ako odporúčanie pre d’alší výstup;

- realizovat' spätnú väzbu zo strany študentov, poskytnút' študentovi priestor na kladenie otázok; 
- zamerat' sa na sebareflexiu, sebahodnotenie študenta;

- inovovat' reflexívne a sebareflexívne techniky.

\section{Záver}

Pri výchove a vzdelávaní v školskom prostredí zohráva nezastupitel'né miesto učitel'. Učitel', ako jeden zo základných činitel'ov výchovno-vzdelávacieho procesu, je nielen sprostredkovatel'om vedomostí, ale rovnako aj kultúrnych tradícií a spoločenských hodnôt. Na učitel'ov sú v súčasnosti kladené nové požiadavky, ktoré menia ich postavenie a kompetencie. Z vykonávatel'ov a implementátorov štátom určeného kurikula sa stávajú tvorcami školského kurikula, ktorého hlavnou myšlienkou je rozvoj žiackych kompetencií (Kosová et al., 2012). Učitelia majú úlohy „.... učit', vykonávat' poradenstvo, inovovat', ale aj pozorovat', hodnotit' a diagnostikovat'...", čo znamená, že sa od nich pri realizácii výučby očakáva aj zvládnutie tohto mimoriadne rozsiahleho a komplexného súboru úloh (Kompolt, 2000).

Už začínajúci učitel' by mal preukázat' požadované zručnosti pri identifikovaní vývinových a individuálnych charakteristík žiaka, psychologických a sociálnych činitel'ov jeho učenia sa, plánovaní a projektovaní vyučovania; realizovaní vyučovania; hodnotení priebehu a výsledkov vyučovania a učenia žiakov či reflektovaní vlastnej pedagogickej činnosti. Uvedené profesijné spôsobilosti by sa teda mali začat' utvárat' počas pregraduálneho štúdia budúcich učitel'ov, kedy si osvojujú edukačné koncepcie a teórie, ktorých účinnost' verifikujú $v$ pedagogickej praxi. $\vee$ tejto oblasti má nenahraditel'nú úlohu cvičný učitel', pretože na jednej strane analyzuje spolu so študentmi učitel'stva ich reakcie na nepredvídané situácie, ktoré v triede nastali a bolo ich potrebné promptne riešit', a na druhej strane sa ocitá akoby v roli supervízora, nielen $v$ zmysle kontroly edukačnej práce budúcich učitel'ov, ale preberá na seba zodpovednost' za organizáciu a realizáciu procesu reflexie, poskytujúc im priestor na rozbor edukačného uvažovania a konania, pýtajúc sa na pohnútky a motívy, ktoré ich vedú $\mathrm{k}$ využitiu vybraných edukačných prostriedkov.

SWOT analýza zameraná na vyučovacie výstupy študenta učitel'stva na pedagogickej praxi poukázala na pozitíva, negatíva, ale tiež na možnosti rozvíjajúce kompetencie budúcich učitel'ov a s tým súvisiace ohrozenia. Ako najdôležitejším prvkom sa javí spätná väzba a reflexia s prvkami konštruktívnej kritiky zo strany cvičného učitel'a a sebareflexia študenta. Jej správna realizácia a uvedomenie si vlastných predností a nedostatkov pri realizácii vyučovacieho procesu rozvíja celú osobnost' študenta - budúceho učitela. $\mathrm{Na}$ základe výsledkov realizovanej analýzy sme inovovali proces praktickej profesijnej prípravy študentov učitel'stva a podporili sme reflexívne a sebareflexívne techniky. Navrhli sme odbornú textovú pomôckou pre cvičných učitel'ov zo základných a stredných škôl, použitel'nú i pre študentov učitel'stva a rovnako aj pre vysokoškolských pedagógov praktickej profesijnej prípravy, ktorá predstavuje inováciu podpory rozvoja diagnostických a reflexívnych kompetencií cvičných učitel'ov a študentov učitel'stva v kontexte fázového modelu pedagogickej praxe.

\section{Pod'akovanie}

Príspevok vznikol s podporou projektu VVGS-2020-1665 „Diagnostická kompetencia cvičného učitel'a ako reflexívneho praktika“.

\section{Literatúra}

Crone, L. J., \& Teddlie, Ch. (1995). Further Examination of Teacher Behavior in Differentially Effective Schools: Selection and Socialization Process. Journal of Classroom Interaction, 30(1), 1-12. 
Čeliňák, Š. (2007). Pedagogická prax je klúčom k učitel'skému povolaniu. In Pedagogická prax súčasnost'a perspektívy (s. 25-30). Nitra: Filozofická fakulta Univerzity Konštantína Filozofa v Nitre.

Crasborn, F. et al. 2010. Capturing mentor teachers'reflective moments during mentoring dialogues. Teachers and teaching: Theory and practice, 16(1), 7-29. [cit. 7.19.2019] Dostupné na: http://dx.doi.org/10.1080/13540600903475462

Danek, J. (2005). Pedagogická prax - neoddelitel'ná súčast' prípravy budúcich učitel'ov. In Pedagogická praxe a profesijní rozvoj studentů. Sborník z mezinárodního pracovního semináre (s. 74-79). Brno: Masarykova univerzita.

Duschinská, K. (2010). Mentoring v procesu stávaní se učitelem [Disertační práce]. Karlova univerzita.

Kasáčová, B. 2005. Reflexívna výučba a reflexia v učitel'skej príprave. Banská Bystrica: Univerzita Mateja Bela, Pedagogická fakulta, 2005. s. 210.

Kasáčová, B. et al. (2006). Profesijný rozvoj učitela. Prešov: MPC.

Kompolt, P. (2000). Diagnostické kompetencie a limity učitela. In Š. Švec (Ed.), Pedagogica. Zborník FF UK (s. 41-55). Bratislava: FF UK.

Korthagen, F. (1992). Techniques for stimulating Reflection in Teacher education Seminars. Teaching and Teacher education, 8(3), 265-274.

Korthagen, F. et al. 2011. Jak spojit praxi s teorií. Didaktika realistického vzdělávání učitelů. Brno: Paido.

Kosová, B. et al. (2012). Vysokoškolské vzdelávanie učitelov. Vývoj, analýza, perspektívy. Banská Bystrica: Pedagogická fakulta Univerzity Mateja Bela.

Kosová, B. (2016). Profesijná príprava budúcich učitel'ov a cvičný učitel' vo svetle medzinárodných trendov. In Švec, V., Lojdová, K., Pravdová, B. (eds.). Učitelské praxe - současné poznatky a perspektivy. Sborník z konference. Brno: Masarykova univerzita. s. $17-29$.

Kosová, B., \& Tomengová, A. et al. (2015). Profesijná praktická príprava budúcich učitel'ov. Banská Bystrica: Belianum. s.13.

Lasley, T. J. (1992). Promoting Teacher Reflection. Journal of Staff Development, 13(1), 24-29.

Minor, L. C., Onwuegbuzie, A. J., Witcher, A. E., \& James, T. L. (2002). Preservice Teachers' Educational Beliefs and Their Perceptions of Characteristics of Effective Teachers. The Journal of Educational Research, 96(2), 116-127. Dostupné na: https://doi.org/10.1080/00220670209598798

Orosová, R. (2017). Pedagogická prax v cvičných školách UPJŠ $v$ Košiciach. Vysokoškolské učebné texty. Košice: UPJŠ v Košiciach.

Orosová, R., Ganajová, M., Rozenfeld J., Desiatniková, L. (2018). Metódy sebareflexie v praktickej profesijnej príprave učitel'ov. JOGSC (Journal of Global Science) 2018, vol. 3, issue 1. [online]. Dostupné na http://jogsc.com/pdf/2018/1/metody_sebareflexie.pdf Orosová, R., Petríková, K., \& Diheneščíková, L. (2018). Sebareflexívny pedagogický denník. Košice: UPJŠ v Košiciach.

Petríková, K., Orosová, R. (2018). Úroveň kompetencií študentov učitel'stva v rámci praktickej profesijnej prípravy. In Vybrané aspekty pedagogickej profesie : zborník vedeckých štúdií. - Prešov : Vydavatel'stvo Prešovskej univerzity.

Rovňanová, L. (2015). Profesijné kompetencie učitel'ov. Banská Bystrica: Belianum.

Schön, D. A. (1987). Educating the reflective practioner toward a new design for teaching and learning in the professions. San Francisco: Jossey-Bass.

Spilková, V. (2004). Současné proměny vzdělávaní učitelů. Brno: Paido.

Spilková, V., \& Tomková, A. et al. (2010). Kvalita učitele a profesní standard. Praha: Pedagogická fakulta Univerzity Karlovy v Praze. 
Zachary, L. J. 2002. The role od Teacher as Mentor. In NEW DIRECTIONS FOR ADULT AND CONTINUING EDUCATION, no. 93 Wiley Periodicals. [cit. 7.15.2019] Dostupné na:

file:///C:/Users/PB/Deskopt/pracovné\%20dokumenty/zachary_role_teacher_mentor.pdf

\section{Adresy autorov}

\section{Mgr. Katarína Petríková, PhD.}

Katedra pedagogiky, Filozofická fakulta, UPJŠ v Košiciach

Šrobárová 2, 04059 Košice

katarina.petrikova@upjs.sk

Doc. PaedDr. Renáta Orosová, PhD.

Katedra pedagogiky, Filozofická fakulta, UPJŠ v Košiciach Šrobárová 2, 04059 Košice

renata.orosova@upjs.sk

\section{PaedDr. Michal Novocký, PhD.}

Katedra pedagogiky, Filozofická fakulta, UPJŠ v Košiciach

Šrobárová 2, 04059 Košice

michal.novocky@upjs.sk 


\title{
DŮLEŽITOST FUNKČNÍHO KOMUNIKAČNÍHO TRÉNINKU U JEDINCŮ S PORUCHAMI AUTISTICKÉHO SPEKTRA A JINÝM VÝVOJOVÝM POSTIŽENÍM
}

\section{THE IMPORTANCE OF FUNCTIONAL COMMUNICATION TRAINING FOR INDIVIDUALS WITH AUTISM SPECTRUM DISORDER AND OTHER DEVELOPMENTAL DISABILITIES}

\author{
Zuzana Prokopová \\ Katedra speciální pedagogiky, Pedagogická fakulta, UK v Prahe
}

\begin{abstract}
:
The aim of this review is to present the results from a source analysis pertaining to the establishment of functional communication training (FCT) for individuals with autism spectrum disorder (ASD) as well as those with other developmental disabilities. Similar to those with other types of cognitive disabilities, individuals with ASD often have varying degrees of deficitis in communicative skills, leading, in many cases, to the development of challenging behavior. FCT is an empirically supported, widely used, and highly effective way of addressing challenging behaviors. Through FCT undesirable behaviors are replaced with a socially acceptable form of communication. This study highlights the importance of FCT in the of education of individuals with ASD as wel as those with other types of developmental disabilities, not only in terms related to the establishment of appropriate communication skills, but also its effect on the reduction of challenging behavior. Additionally, this study draws attention to the need to advance the competencies for the establishment and management of FCT for special educators and other similar professionals to reduce their dependence on behavioral specialists in situations where resources are limited.
\end{abstract}

\section{Key words:}

Functional communication training (FCT), autism spectrum disorder (ASD), challenging behavior

\section{Teoretická východiska}

Poruchy autistického spektra (dále jen PAS) patří mezi častá neurovývojová postižení. Jejich výskyt se v posledních letech stále zvyšuje. CDC (Centres of Disease Control and Prevention) udává prevalenci PAS až 1:54 (CDC, 2020). PAS se projevují narušením komunikačních a sociálních dovedností a dále prítomností stereotypních vzorců chování, aktivit či zájmů. Obtíže ve výše zmíněných oblastech mohou vyústit v nežádoucí chování různého typu, četnosti a různé intenzity. Častým důvodem jeho vzniku je právě deficit v komunikačních dovednostech. Nežádoucí chování se může manifestovat jako sebepoškozování, agresivní chování vưči druhým, nevhodné sexuální projevy apod. Má výrazný dopad na kvalitu života jedince s PAS i jeho rodiny (Bazalová, 2017; Hrdlička, Komárek, 2014).

Jednou z často užívaných a doporučovaných intervencí vedoucích k eliminaci nežádoucího chování je funkční komunikační trénink (dále jen FCT). Cílem FCT je nahradit nežádoucí chování funkčním komunikačním ekvivalentem, tedy sociálně 
přijatelným způsobem komunikace. Tento ekvivalent má za úkol zajistit stejné posílení, jaké dosud přinášelo nežádoucí chování. Mủže mít mnoho podob, jako například formu vokální, komunikaci využívající znaky, komunikační desku, kartičky se slovy či obrázky, hlasový prístroj apod. (Shirley, Iwata, Kahng, Mazaleski \&Lerman in Cooper, Heron, Heward, 2019). Carr a Durand (1985) popisují FCT jako proces skládající se ze dvou kroků. V prvním kroku dochází $\mathrm{k}$ posouzení funkce nežádoucího chování a v kroku druhém k učení alternativní odpovědi, která povede k dosažení stejného posílení, jímž bylo nežádoucí chování udržováno (Carr a Durand in Cooper, Heron, Heward, 2019).

\section{Metodika šetření}

Hlavní technikou výzkumu byla přehledová studie, jejímž cílem bylo sledování vlivu FCT na nežádoucí chování. Byla analýzována dostupná literatura zabývající se využitím FCT u jedinců s PAS a jiným vývojovým postižením. Kritériem výběru byla odborná stat' na dané téma publikovaná $v$ časovém rozmezí od roku 2018 do 2020. Vyhledávání probíhalo prostřednictvím Portálu elektronických zdrojů UK v databázích Academic Search Ultimate, EBSCO, Scopus, Springer Nature Journals, JSTOR Journals, ScienceDirect a dalších. Získané výzkumné články byly dále redukovány na relevantní dle abstraktu. Pro zpracování přehledové studie bylo vybráno 20 statí splňujících výše uvedená kritéria. Citace výzkumných studií jsou uvedeny $\checkmark$ přehledu literatury.

\section{Interpretace poznatků z výzkumu zabývajícího se využíím FCT}

Vybrané výzkumy, které byly pro zpracování přehledové studie použity, se zaměřují nejčastěji na snížení nežádoucího chování a na jeho návrat po ukončení FCT či v jeho průběhu. Dále poukazují na vliv technik jako je signalizace dostupnosti posílení, zpoždění posílení či nabídka alternativního posílení. Téměř všechny námi analyzované vědecké studie potvrzují signifikantní snížení nežádoucího chování po zařazení FCT u jedinců s PAS či jiným vývojovým postižením. Řešeným nežádoucím chováním bylo zejména závažné disruptivní chování, agrese vưči druhým, sebepoškozující chování a stereotypní chování. Pro zjištění funkcí nežádoucího chování byla většinou výzkumníků provedena funkční analýza chování. Nejčastěji zjištěnými funkcemi byl únik od požadavku, dosažení pozornosti a dosažení posílení. Z výzkumné studie, jejímž cílem bylo definovat společné charakteristiky nejčastějších účastníků $F C T$, můžeme konstatovat, že ve více než polovině případů je FCT indikován u jedinců s PAS a dále u jedinců s mentálním a kombinovaným postižením. V 70 \% se jedná o jedince mužského pohlaví (Gerow et al., 2018).

Často řešeným problémem, objevujícím se např́č mnoha výzkumy, je návrat nežádoucího chování po ukončení nebo v průběhu FCT. Briggs et al. (2018) provedl výzkumné šetření, které se zaměřovalo na návratnost nežádoucího chování u jedinců s PAS a jiným vývojovým postižením zapojených do FCT. Studie shromáždila data 25 participantů a potvrdila návrat nežádoucího chování u 76 \% případů (Briggs et al., 2018). K návratu nežádoucího chování docházelo zejména $v$ době, kdy se začínal ztenčovat rozvrh posílení, tzn., že posílení již nebylo doručováno tak často, jako na počátku tréninku a také častěji docházelo k jeho zamítnutí (Torres-Viso, Strohmeier, Zarcone, 2018). Jako další situace, kdy docházelo k návratu nežádoucího chování, byl výzkumníky uveden přechod $z$ učení $v$ prísně kontrolovaném prostředí do domácího prostředí, či přechod od učení se za podpory zkušených terapeutů k učení rodiči či pečovateli, se kterými měl již participant vybudovanou určitou historii posílení nežádoucího chování (Saini et al., 2018). Mezi techniky, které jsou využívány při prevenci návratu nežádoucího chování, a které jsou hodnoceny jako úspěšné, patři např. konkurenční aktivita (aktivita, kterou jedinec dosahuje posílení, aniž by se zapojil do nežádoucího chování), ke které je participantům umožněn prístup v době zamítnutí 
preferovaného posílení (Fuhrman et al., 2018). Jako efektivní se také jeví nabídnutí alternativního posílení (Sumter et al., 2020). Další doporučovanou technikou vedoucí k poklesu nežádoucího chování je učení odpovědí nahrazujících nežádoucí chování v alternativním antecedentním kontextu, tzn. mimo situaci, ve které dochází k nežádoucímu chování. Suess et al. (2020) uvádí, že pokud je sociálně přijatelná odpověd' naučena mimo kontext, tedy $v$ době, kdy se žádné nežádoucí chování nevyskytuje, je pravděpodobné, že se jedinec naučí tuto alternativní odpověd’ využívat namísto nežádoucího chování. V rámci některých námi analyzovaných studií byla úspěšně využívána strategie pracující se signalizací dostupnosti posílení, což v kombinaci s vyhasínáním nežádoucího chování vedlo k jeho snížení (Boyle et al., 2018; Davis et al., 2018; Greer et al., 2019).

Výzkumy se rovněž shodují na efektivitě implementace procesu vyhasínání nežádoucího chování v rámci FCT. Je zapotřebí nejen budovat alternativní chování produkující totéž posílení jako přinášelo nežádoucí chování, ale zároveň by nemělo být nežádoucí chování nadále posilováno, aby nedocházelo k naplnění jeho funkce (Mullane et al., 2020; TorresViso, Strohmeier, Zarcone, 2018). U participantů, u kterých byl funkcí nežádoucího chování únik od požadavku, se jako úspěšné řešení ukázalo učení mandů o snížení požadavků, pauzu či odchod ze situace (Gerow et al., 2020).

Dle dalších výzkumných zjištění má vliv na pokles výskytu nežádoucího chování také variabilita mandů. $V$ některých studiích bylo pro její zvýšení využíváno v rámci FCT tzv. lag rozvrhu posílení, kterým se posiluje odpověd’ odlišná od odpovědi předchozí. Tím rozmanitost mandů prírozeně roste (Silbaugh et al., 2020; Schmitz et al., 2019). Ovšem i tam, kde byla rozvíjena variabilita mandů, docházelo k návratu nežádoucího chování. To mohlo být způsobeno vlivem dlouhé historie jeho posílení (Schmitz et al., 2019). Variability mandů bylo dosahováno nejen s využitím lag rozvrhu posílení, ale také pomocí zpoždění posílení. Muething et al. (2020) uvádí, že ačkoli variabilita mandů u všech participantů vzrostla, efekt na výskyt nežádoucího chování byl napríč souborem participantů různý (Muething et al., 2020). Mullane et al. (2020) ve své studii poukazuje na souvislost mezi snížením nežádoucího chování a snížením zpoždění posílení (Mullane et al., 2020).

Fisher et al. (2018) zmiňuje jako vhodný přistup vedoucí k eliminaci nežádoucího chování během FCT okamžitý prompt k sociálně vhodné odpovědi (Fisher et al., 2018). Neprodlený prompt při učení mandů byl poskytován rovněž participantům v rámci výzkumu provedeného Lambertem (2020). Oba výzkumy potvrdily, že když při snížení doby čekání na posílení se současně snižuje i výskyt nežádoucího chování. Tam, kde se v rámci testovacích podmínek zvyšovala doba prodlení s promptem, zvyšovala se i frekvence nežádoucího chování (Fisher et al., 2018; Lambert et al., 2020).

Několik studií shodně doporučuje zařazení tréninku rodičů či pedagogů v provádění FCT a analýzy funkcí nežádoucího chování. Důvodem je především snížení závislosti na behaviorálních terapeutech, ale také zvýšení efektivity edukace těchto jedinců v domácím i školním prostředí (Lindgren et al., 2020; Luck et al., 2020). Tsami a Lerman (2020) a další navrhují na základě svých zjištění využít pro trénink dovedností potřebných k provádění FCT telekomunikační technologie. Možnost jejich využití zvyšuje dostupnost tréninku pro mnohé zájemce (Lindgren et al., 2020; Suess et al.; 2020; Tsami, Lerman, 2020).

\section{Závěr}

Přehledová studie potvrzuje, že výzkumná šetření zabývající se FCT u jedinců s PAS a jiným vývojovým postižením jsou velmi silně podložena. Studie se shodují, že intervence založené na FCT podporují snížení nežádoucího chování a současně je pomocí nich budován sociálně přijatelný způsob komunikace. $V$ přehledové studii jsou diskutovány konkrétní př́stupy vedoucí k rozvoji funkční komunikace a eliminaci nežádoucího 
chování. Studie je prínosná z hlediska sumarizace poznatků z výzkumu týkajícího se FCT u jedinců s PAS a jiným vývojovým postižením v posledních dvou letech. Zároveň také předkládá nové poznatky a zkušenosti v oblasti využití techniky FCT, které v českém a slovenském prostředí stále absentují.

\section{Vysvětlení pojmů}

Antecedent je změna v prostředí, ke které dochází před výskytem chování (Cooper, Heron, Heward, 2019).

Lag rozvrh posílení je jednou z metod využívaných pro zvýšení variability určitého chování. Je při něm posilována odpověd' odlišná od odpovědi předchozí (Cooper, Heron, Heward, 2019).

Mand je jedním z primárních verbálních operantů definovaných $B$. F. Skinnerem $v$ jeho analýze verbálního chování. Termín mand vychází z anglického „demand“ a znamená žádost či požadavek. Může se jednat o žádost o předmět, aktivitu, pozornost nebo napríklad informaci (Cooper, Heron, Heward, 2019).

Posílení je jedním ze základních principů chování. Jedná se o následek přicházející po chování, který zvyšuje pravděpodobnost, že jedinec chování bude v budoucnu opakovat (Barbera, Rasmussen, 2007).

Prompt je nápověda, pomocí níž facilitujeme správnou odpověd' (Barbera, Rasmussen, 2007).

Rozvrh posílení je pravidlo specifikující požadavky pro dosažení posílení Cooper, Heron, Heward, 2019).

Vyhasínání je proces, při kterém chování, jež bylo v minulosti posilováno, nadále posilováno být přestává a tím dochází ke snížení jeho výskytu (Cooper, Heron, Heward, 2019).

\section{Poděkování}

Tento príspěvek vznikl ve spolupráci s Univerzitou Karlovou, Pedagogickou fakultou, Katedrou Speciální pedagogiky a za finanční podpory GA UK, číslo projektu 141020.

\section{Literatura}

Barbera, M., Rasmussen, T. (2007). The Verbal Behavior Approach: How to Teach Children With Autism and Related Disorders. London and Philadelphia: Jessica Kingsley

Publishers

BAZALOVÁ, Barbora. (2017). Autismus v edukační praxi. Praha: Portál

BOYLE, Megan A., Mary E. ORTMAN, Alexandra C. BECKMAN, Stephanie L. AHOLT, Ginny L. KEENAN. (2018) Functional communication training and noncontingent reinforcement in treatment of stereotypy. Behavioral Interventions, 33(1), 79-86

BRIGGS, Adam M., Wayne W. FISHER, Brian D. GREER a Ryan T. KIMBALL. (2018) Prevalence of resurgence of destructive behavior when thinning reinforcement schedules during functional communication training. Journal of Applied Behavior Analysis, 51(3), 620-633

COOPER, John O., Timothy E. HERON, T., William L. HEWARD. (2019) Applied Behavior Analysis. (3. vydání). Upper Saddle River, Nj: Pearson

Data \& Statistics on Autism Spectrum Disorder/CDC. Centres for Disease Control and Prevention. (2020) Dostupné z: https://www.cdc.gov/ncbddd/autism/data.html

DAVIS, Tonya N., Regan WESTON, Abby HODGES, Lauren UPTEGROVE, Kristen WILLIAMS a Kelly M. SCHIELTZ. (2018) Functional Communication Training and Demand Fading Using Concurrent Schedules of Reinforcement. Journal of Behavioral Education, 27(3), 343-357

FISHER, Wayne W., Brian D. GREER, Daniel R. MITTEER, Ashley M. FUHRMAN, Patrick W. ROMANI a Amanda N. ZANGRILLO. (2018) Further evaluation of differential 
exposure to establishing operations during functional communication training. Journal of Applied Behavior Analysis, 51(2), 360-373

FUHRMAN, Ashley M., Brian D. GREER, Amanda N. ZANGRILLO a Wayne W. FISHER. (2018) Evaluating Competing Activities to Enhance Functional Communication Training during Reinforcement Schedule Thinning. Journal of Applied Behavior Analysis, 51(4), 931-942

GEROW, Stephanie, Supriya RADHAKRISHNAN, Tonya N. DAVIS, Abby HODGES a Amy FEIND. (2020) A Comparison of Demand Fading and a Dense Schedule of Reinforcement During Functional Communication Training. Behavior Analysis in Practice, 13(1), 90-103

GEROW, Stephanie, Tonya DAVIS, Supriya RADHAKRISHNAN, Emily GREGORI a Gabby RIVERA. (2018) Functional Communication Training: The Strength of Evidence across Disabilities. Exceptional Children, 85(1), 86-103

GREER, Brian D., Wayne W. FISHER, Adam M. BRIGGS, Katherine R. LICHTBLAU, Lauren A. PHILLIPS a Daniel R. MITTEER. (2019) Using Schedule-Correlated Stimuli During Functional Communication Training to Promote the Rapid Transfer of Treatment Effects. Behavioral Development Bulletin, 24(2), 100-119

HRDLIČKA, Michal., Vladimír KOMÁREK. (2014) Dětský autismus: přehled současných poznatků. (2., dopl. vydání). Praha: Portál

LAMBERT, Joseph M., Jessica N. TORELLI, Nealetta J. HOUCHINS-JUAREZ, Savannah A. TATE a Jessica L. PARANCZAK. (2020) The Effect of Abolishing Operations on Mand Acquisition During Functional Communication Training. Journal of Behavioral Education, 1-20

LINDGREN, Scott, David WACKER, Kelly SCHIELTZ, et al. (2020) A Randomized Controlled Trial of Functional Communication Training via Telehealth for Young Children with Autism Spectrum Disorder. Journal of Autism and Developmental Disorders, 1-14

LUCK, Kally M., Dorothea C. LERMAN, Sarah D. WILLIAMS a Victoria L. FLETCHER. (2020) Training Special Education Teachers to Select and Implement Appropriate Procedural Variations of Functional Communication Training. Journal of Behavioral Education, 1-17

MUETHING, Colin S., Terry S. FALCOMATA, Raechal FERGUSON, Samantha SWINNEA a Cayenne SHPALL. (2018) An evaluation of delay to reinforcement and mand variability during functional communication training. Journal of Applied Behavior Analysis, 51(2), 263-275

MULLANE, Michael P., Brian K. MARTENS, Samantha J. SALLADE a Emily L. BAXTER. (2020) Preference for variable over fixed delays to reinforcement: A demonstration of risk sensitivity during functional communication training. Behavior Analysis: Research and Practice

SAINI, Valdeep, William E. SULLIVAN, Emily L. BAXTER, Nicole M. DEROSA a Henry S. ROANE. (2018) Renewal during Functional Communication Training. Journal of Applied Behavior Analysis, 51(3), 603-619

SCHMITZ, Brittany, Bethany P. CONTRERAS, Savannah TATE a Sungwoo KAHNG. (2019) Variations of Functional Communication Training and Their Effects on Resurgence. Current Developmental Disorders Reports, 6(4), 209-216

SILBAUGH, Bryant C., Samantha SWINNEA a Terry S. FALCOMATA. (2020) Replication and Extension of the Effects of Lag Schedules on Mand Variability and Challenging Behavior During Functional Communication Training. The Analysis of Verbal Behavior, 36(1), 49-73

SUESS, A.N., J. DETRICK, K.M. SCHIELTZ, D.P. WACKER a C.A. PODLESNIK. (2020) An evaluation of resurgence following functional communication training conducted 
in alternative antecedent contexts via telehealth. Journal of the Experimental Analysis of Behavior, 113(1), $278-301$

SUMTER, M.E., M.R. GIFFORD, J.H. TIGER, H.M. EFFERTZ a C.J. FULTON. (2020) Providing noncontingent, alternative, functional reinforcers during delays following functional communication training. Journal of Applied Behavior Analysis, 1-11

TORRES-VISO, Mariana, Craig W. STROHMEIER a Jennifer R. ZARCONE. (2018) Functional analysis and treatment of problem behavior related to mands for rearrangement. Journal of Applied Behavior Analysis, 51(1), 158-165

TSAMI, Loukia a Dorothea C. LERMAN. (2020) Transfer of treatment effects from combined to isolated conditions during functional communication training for multiply controlled problem behavior. Journal of Applied Behavior Analysis, 53(2), 649-664

\section{Adresa autora}

\section{Mgr. Zuzana Prokopová}

Katedra speciální pedagogiky, Pedagogická fakulta, UK v Prahe

Magdalény Rettigové 4, 11639 Praha 1

prokopovazuzana@seznam.cz

Školitel: prof. PaedDr. Miroslava Bartoňová, Ph.D. 


\title{
IDENTIFIKÁCIA ZÁUJMU O ŠTÚDIUM ŠTUDIJNÝCH ODBOROV PEDAGOGICKÉHO ZAMERANIA V SÚČASNEJ VYSOKOŠKOLSKEJ EDUKÁCII
}

\section{AGNOSCATION OF UNIVERSITY STUDENTS INTEREST IN THE TEACHING EDUCATION AT UNIVERSITIES IN SLOVAK REPUBLIC}

\author{
Mariana Sirotová \\ Katedra pedagogiky, Filozofická fakulta, UCM v Trnave \\ Veronika Michvocíková \\ Katedra pedagogiky, Filozofická fakulta, UCM v Trnave
}

\begin{abstract}
:
University education of university students - future teachers is one of the important part of education of young people. Young people - university students have decided to become a teacher. Teaching profession is very difficult and university education of future teachers is characterized as a consistent process. It is based on application of theoretical knowledge to the educational process by supervised practice teaching during university education of future teacher. The main aim of study is to agnose university students interest in the teaching education at universities in Slovak Republic. The study has theoretical and empirical character. In the theoretical part, there are definitions of university education of future teachers. There is the description of the teacher position in nowadays society. In the empirical part, there is the statistical overview of the number of university students of teaching university study fields in the period $2015-2019$ at the Slovak universities. The statistical overview of the number of university students of teaching education is the indicator of motivation of teaching profession realization by young people in the future.
\end{abstract}

Key words:

teaching profession, university education, university students

\section{Úvod}

PInohodnotné vykonávanie každého povolania si v súčasnom spoločenskom systéme vyžaduje adekvátnu odbornú prípravu. Jej charakter a priebeh závisí predovšetkým od špecifík vyžadovaných v konkrétnej profesii. Za jednu z profesií nezanedbatel'ných pre súčasnú spoločnost' považujeme aj profesiu učitel'a. Práve vykonávanie učitel'ského povolania si vyžaduje vysokoškolskú prípravu zahŕňajúcu osvojenie si teoretických poznatkov spoločne s prepojením ich praktickej aplikácie v edukačnom procese už počas vysokoškolského štúdia budúceho učitel'a. Z tohto dôvodu smeruje centrum našej pozornosti $\mathrm{k}$ všeobecnému charakterizovaniu profesie učitel'a $v$ súčasnej spoločnosti. Rovnako $v$ predkladanej štúdii poukážeme na záujem o vysokoškolské štúdium vybraných študijných odborov pedagogického zamerania na Slovensku prostredníctvom štatistického prehladu o počte vysokoškolských študentov uvedených študijných 
odborov v stanovenom období, ktorý podla nášho názoru indikuje záujem/ nezáujem mladých l'udí o vykonávanie učitel'ského povolania.

\section{Pregraduálna príprava a profesia učitel'a v súčasnej spoločnosti}

Učitel'a možno považovat' za neodmyslitel'nú súčast' edukačného procesu. Je to odborník, ktorý vedie výchovno-vzdelávací proces. Aj napriek existujúcej feminizácii tohto povolania sa vo všeobecnej terminológii používa prevažne $v$ mužskom rode na označenie odborníka, ktorý vykonáva edukačnú prácu na niektorom type školy a zároveň spĺn̆a určené kvalifikačné predpoklady (Kasáčová, 2004, s. 15). Prvotné charakterizovanie učitel'a ako kvalifikovaného edukačne pôsobiaceho odborníka sa spája s určitou mierou autonómie. Pri rôznych výchovných situáciách musí vediet' posúdit' potreby diet'at'a, vediet' flexibilne reagovat' a zároveň uskutočnit' vhodné intervencie. Vo vzdelávacích situáciách je autonómia učitel'a čiastočne obmedzovaná uniformitou vzdelávacích ciel'ov a obsahov (Kosová, 2005, s. 102). Učitel' je osoba, ktorá sa počas svojho pôsobenia vo výchovno-vzdelávacom procese pravidelne stretáva s rozmanitými výchovnými situáciami. Na tieto situácie musí vediet' adekvátne a pohotovo zareagovat'. Rovnako aj jeho následné konanie musí byt' adekvátne vzniknutej situácii. Preto je dôležité, aby sa učitel' dokázal samostatne rozhodovat'. Musíme zdôraznit', že profesionálny výkon učitel'ského povolania sa zakladá aj na rešpektovaní stanovených ciel'ov výchovy a vzdelávania. Taktiež je potrebné aj dodržiavanie spôsobov určených na ich dosahovanie. Učitel' síce na jednej strane vedie výchovno-vzdelávací proces, pri riešení širokého spektra výchovných situácií sa rozhoduje na základe vlastného uváženia. No na druhej strane nesmie svojvol'ne menit' príslušné vzdelávacie obsahy a vymedzené ciele výchovy a vzdelania.

Ak sústredíme centrum pozornosti na význam učitel'skej profesie $v$ súčasnosti, tak „vedecký a technický pokrok, ktorý priniesla druhá polovica 20. storočia, zmenil pohl'ad na vzdelávanie aj na pozíciu učitel'a. Vzdelanie začalo byt' vnímané ako dôležitá investícia do l'udského kapitálu nevyhnutného pre ekonomickú prosperitu vyspelých krajín“ (Vančíková, 2011, s. 120). Avizovaná zmena ponímania dôležitosti vzdelávania a zdôrazňovania významu pozície učitel'a v spoločnosti sa podl'a nášho názoru dotýkala predovšetkým druhej polovice 20. storočia. V súčasnosti je síce kladený dôraz na vzdelanie, no na strane druhej je pozícia učitel'a v spoločnosti vnímaná ako každá iná a nie je jej pripisované žiadne zvláštne spoločenské uznanie. Podobný, no čiastočne odlišný názor zastáva Kasáčová, zdôrazňujúca existenciu niekol'kých všeobecných nevýhod pripisovaných učitel'skej profesii, medzi ktoré zarad'uje početnost', feminizáciu, starnutie učitel'ských zborov, nízke platové ohodnotenie spojené s nízkou atraktívnost'ou, znižujúcou spoločenskú prestíž učitel'stva. Aj napriek tomu však narastá spoločenské uznanie, ktoré sa pripisuje učitel'om ako profesijnej skupine (Kasáčová, 2004, s. 90). Súhlasíme s vyššie uvedenými nevýhodami pripisovanými učitel'skej profesii. Spoločenské uznanie učitel'ov je však podla nášho názoru viditel'né len vel'mi málo. Stretávame sa skôr s odlišnými názormi nedoceňujúcimi význam a náročnost' edukačnej práce z celospoločenského pohl'adu. Taktiež sa postupne vytráca aj individuálne subjektívne uvedomenie si poslania učitel'ov - vzdelávat' a vychovávat'.

$\checkmark$ neposlednom rade načrtneme aj vnímanie učitel'stva z pohladu vysokoškolských študentov - budúcich učitel'ov - vyplývajúce z čiastkových výsledkov výskumu realizovaného na Filozofickej fakulte na Univerzite Pavla Jozefa Šafárika. Svoje ponímanie učitel'stva vyjadrovalo 39 oslovených vysokoškolských študentov - budúcich učitel'ov. Na základe otvoreného kódovania boli stanovené tri nasledujúce kategórie ponímania učitel'stva (Šmajdová Bušová, 2015, s. 255):

1) učitel'stvo charakterizované ako vykonávanie vytúženého povolania,

2) učitel'stvo charakterizované ako jedna z možností, 
3) učitel'stvo charakterizované ako „východisko z núdze“ v prípade, že študentom nič iné nevyšlo.

Aj na základe uvedených kategórií vnímania učitel'skej profesie z pohladu budúcich učitel'ov môžeme skonštatovat', že vysokoškolskí študenti majú rôzne dôvody $\mathrm{k}$ štúdiu učitel'stva. $V$ prvom rade hovoríme $v$ súvislosti s učitel'stvom o vytúženom povolaní, ktorého realizácia bude vysokoškolského absolventa učitel'stva napíňat'. Okrem toho môže byt' učitel'ské povolanie vnímané mladým človekom aj ako možnost' stat' sa vysokoškolským študentom. Myslíme si však, že celkové ponímanie učitel'stva budúcimi učitel'mi závisí aj od charakteru pregraduálnej prípravy.

\section{Štúdium pedagogického zamerania na slovenských vysokých školách}

V empirickej časti našej štúdie chceme poukázat' na počet vysokoškolských študentov študijných odborov pedagogického zamerania na slovenských vysokých školách. Hlavným ciel'om nášho skúmania je zistenie a zaznamenanie prehl'adu počtu vysokoškolských študentov študujúcich študijné odbory pedagogického zamerania na slovenských vysokých školách v stanovenom období, na základe ktorého môžeme načrtnút' záujem o štúdium učitel'stva na Slovensku.

\section{Materiál a metodika}

Na základe stanoveného ciela nášho skúmania sme analyzovali dáta zaznamenané na zvolenej internetovej stránke, obsahujúcej štatistické údaje o vysokoškolských študentoch študujúcich na slovenských vysokých školách. Za relevantný zdroj uvedených údajov považujeme údaje zaznamenané v Štatistických ročenkách Slovenskej republiky (dostupné na www.cvtisr.sk). Štatistické ročenky Slovenskej republiky zamerané na školstvo obsahujú exaktné údaje o počtoch všetkých vysokoškolských študentov študujúcich na všetkých vysokých školách na území Slovenskej republiky. Údaje o počtoch vysokoškolských študentov sú vždy v každom roku Štatistickej ročenky usporiadané podl'a študijného odboru a knemu zodpovedajúcom študijnom programe. Preto sme nižšie analyzované údaje čerpali z dostupných štatistických údajov o počtoch vysokoškolských študentov študujúcich na všetkých vysokých školách na území Slovenskej republiky v sledovanom rozpätí rokov 2015 - 2019. Uvedený interval sme zvolili z dôvodu relatívnej aktuálnosti analyzovaných údajov.

\section{Analýza a interpretácia údajov}

Podla nášho názoru môžeme prostredníctvom vytvorenia avizovaného stručného štatistického prehl'adu načrtnút' záujem mladých l'udí o vysokoškolské vzdelávanie umožňujúce vykonávanie učitel'ského povolania na Slovensku. V nasledujúcej tabul'ke (Tabul'ka 1) sme vytvorili prehl'ad počtu všetkých vysokoškolských študentov študujúcich vybrané študijné odbory pedagogického zamerania na verejných a na súkromných slovenských vysokých školách v dennej aj v externej forme v rozpätí rokov 2015 - 2019. Za študijné odbory pedagogického zamerania považujeme v rámci koncipovania nášho príspevku tri vybrané študijné odbory - pedagogické vedy, učitel'stvo, učitel'stvo predmetov $\vee$ kombináciách. 
Tab. 1: Prehl'ad počtu vysokoškolských študentov študujúcich vybrané pedagogické študijné odbory v rokoch 2015 - 2019

\begin{tabular}{|c|c|c|c|c|c|c|c|c|}
\hline \multirow{2}{*}{ 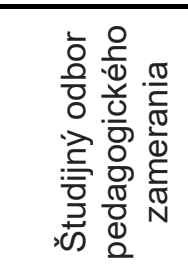 } & \multirow{2}{*}{ 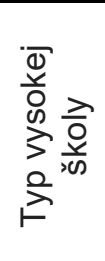 } & \multirow{2}{*}{ 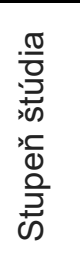 } & \multirow{2}{*}{ 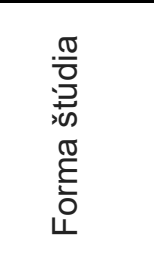 } & \multicolumn{4}{|c|}{$\begin{array}{l}\text { Počet vysokoškolských } \\
\text { v uvedenom roku v príslušnom } \\
\text { odbore }\end{array}$} & $\begin{array}{l}\text { studentov } \\
\text { studijnom }\end{array}$ \\
\hline & & & & 2015 & 2016 & 2017 & 2018 & 2019 \\
\hline \multirow{5}{*}{ 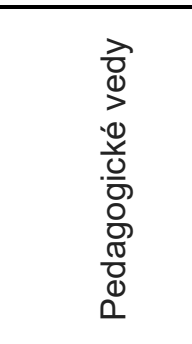 } & \multirow{4}{*}{ 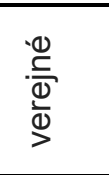 } & \multirow{2}{*}{$\begin{array}{l}\text { I. } \\
\text { a II. }\end{array}$} & denná & 5065 & 4895 & 4771 & 4708 & 4554 \\
\hline & & & externá & 3408 & 3216 & 2855 & 2821 & 3005 \\
\hline & & \multirow[t]{2}{*}{ III. } & denná & 144 & 92 & 98 & 90 & 85 \\
\hline & & & externá & 105 & 118 & 96 & 83 & 85 \\
\hline & 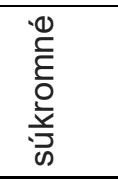 & III. & 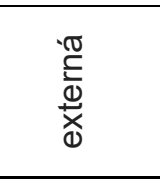 & & 23 \\
\hline \multicolumn{4}{|c|}{$\begin{array}{l}\text { Spolu počet vysokoškolských študentov } \\
\text { v študijnom odbore pedagogické vedy } \\
\text { k 31.12. }\end{array}$} & 8722 & 8321 & 7820 & 7702 & 7752 \\
\hline \multicolumn{4}{|c|}{$\begin{array}{l}\text { Spolu počet vysokoškolských študentov } \\
\text { študujúcich v študijnom odbore pedagogické } \\
\text { vedy k } 31.12 \text {. (podiel v \% z celkového počtu } \\
\text { vysokoškolských študentov študujúcich } \\
\text { vybrané študijné odbory pedagogického } \\
\text { zamerania) }\end{array}$} & 44,29 & 45,82 & 46,10 & 46,65 & 47,20 \\
\hline \multicolumn{4}{|c|}{$\begin{array}{l}\text { Spolu počet vysokoškolských študentov } \\
\text { študujúcich v študijnom odbore pedagogické } \\
\text { vedy k 31.12. (podiel v \% z celkového počtu } \\
\text { vysokoškolských študentov na Slovensku) }\end{array}$} & 5,85 & 6,06 & 6,23 & 6,38 & 6,62 \\
\hline \multirow{5}{*}{ 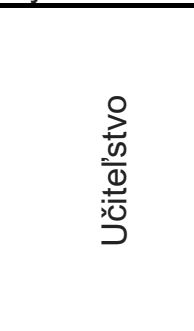 } & \multirow{3}{*}{ 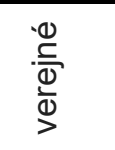 } & \multirow{3}{*}{$\begin{array}{l}\text { I. } \\
\text { a II. } \\
\text { III. }\end{array}$} & denná & 1319 & 1280 & 1221 & 1181 & 1157 \\
\hline & & & externá & 487 & 394 & 270 & 275 & 247 \\
\hline & & & denná & \multicolumn{4}{|l|}{-} & 85 \\
\hline & $\stackrel{\oplus}{=}$ & & denná & 75 & 39 & 71 & 43 & 305 \\
\hline & 旁 & a II. & externá & 1421 & 1193 & 1291 & 1329 & 1024 \\
\hline \multicolumn{4}{|c|}{$\begin{array}{l}\text { Spolu počet vysokoškolských študentov } \\
\text { študujúcich v študijnom odbore } \\
\text { k 31.12. v príslušnol'stvo roku }\end{array}$} & 3302 & 2906 & 2853 & 2828 & 2818 \\
\hline \multicolumn{4}{|c|}{$\begin{array}{l}\text { Spolu počet vysokoškolských študentov } \\
\text { študujúcich v študijnom odbore učitel'stvo } \\
\text { k 31.12. (podiel v \% z celkového počtu } \\
\text { vysokoškolských študentov študujúcich } \\
\text { vybrané študijné odbory pedagogického } \\
\text { zamerania) }\end{array}$} & 16,77 & 16,00 & 16,82 & 17,13 & 17,16 \\
\hline \multicolumn{4}{|c|}{ 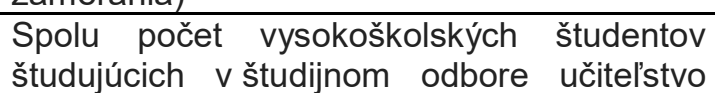 } & 2,22 & 2,12 & 2,27 & 2,34 & 2,41 \\
\hline
\end{tabular}




\begin{tabular}{|c|c|c|c|c|c|c|c|c|}
\hline \multicolumn{9}{|c|}{$\begin{array}{l}\text { k 31.12. (podiel v \% z celkového počtu } \\
\text { vysokoškolských študentov na Slovensku) }\end{array}$} \\
\hline \multirow{2}{*}{$\begin{array}{l}\text { Učitel'stvo } \\
\text { predmetov } \\
\text { v kombináciách }\end{array}$} & \multirow{2}{*}{ verejné } & \multirow[b]{2}{*}{$\begin{array}{l}\text { I. } \\
\text { a II. }\end{array}$} & denná & 7307 & 6658 & 6122 & 5819 & 5743 \\
\hline & & & externá & 363 & 265 & 169 & 160 & 109 \\
\hline \multicolumn{4}{|c|}{$\begin{array}{lrr}\text { Spolu počet vysokoškolských } & \text { študentov } \\
\text { študujúcich v študijnom odbore } & \text { učitel'stvo } \\
\text { predmetov v kombináciách } & \text { k 31.12. } \\
\text { v príslušnom roku } & \end{array}$} & 7670 & 6932 & 6291 & 5979 & 5852 \\
\hline \multicolumn{4}{|c|}{$\begin{array}{l}\text { Spolu počet vysokoškolských študentov } \\
\text { študujúcich v študijnom odbore učitel'stvo } \\
\text { predmetov v kombináciách k } 31.12 \text {. (podiel v } \\
\% \quad \text { z celkového počtu vysokoškolských } \\
\text { študentov študujúcich vybrané študijné } \\
\text { odbory pedagogického zamerania) }\end{array}$} & 38,95 & 38,17 & 37,08 & 36,22 & 35,64 \\
\hline \multicolumn{4}{|c|}{$\begin{array}{l}\text { Spolu počet vysokoškolských študentov } \\
\text { študujúcich v študijnom odbore učitel'stvo } \\
\text { predmetov v kombináciách k } 31.12 \text {. (podiel v } \\
\% \text { z celkového počtu vysokoškolských } \\
\text { študentov na Slovensku) }\end{array}$} & 5,15 & 5,05 & 5,02 & 4,95 & 5,00 \\
\hline \multicolumn{4}{|c|}{$\begin{array}{l}\text { Spolu počet študentov študujúcich študijné } \\
\text { odbory pedagogického zamerania k } 31.12 \text {. }\end{array}$} & 19694 & 18159 & 16949 & 16509 & 16422 \\
\hline \multicolumn{4}{|c|}{$\begin{array}{l}\text { Spolu počet vysokoškolských študentov } \\
\text { študujúcich študijné odbory pedagogického } \\
\text { zamerania k } 31.12 \text {. (podiel v \% z celkového } \\
\text { počtu vysokoškolských študentov na } \\
\text { Slovensku) }\end{array}$} & 13,21 & 13,22 & 13,52 & 13,70 & 14,02 \\
\hline \multirow{8}{*}{$\begin{array}{l}\text { Celkový počet } \\
\text { študentov }\end{array}$} & \multirow{4}{*}{ 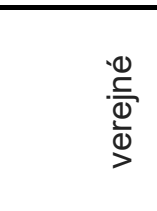 } & \multirow{2}{*}{$\begin{array}{l}\text { I. } \\
\text { a II. }\end{array}$} & denná & 105577 & 99140 & 92444 & 88774 & 86837 \\
\hline & & & externá & 19085 & 16495 & 13578 & 12937 & 12562 \\
\hline & & \multirow[t]{2}{*}{ III. } & denná & 4283 & 3845 & 3637 & 3514 & 3378 \\
\hline & & & externá & 2503 & 2284 & 2158 & 2021 & 1933 \\
\hline & \multirow{4}{*}{ 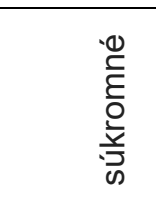 } & \multirow{2}{*}{ I. } & denná & 5810 & 4721 & 4834 & 5042 & 5141 \\
\hline & & & externá & 11351 & 10544 & 8526 & 8205 & 7018 \\
\hline & & \multirow[t]{2}{*}{ III. } & denná & 79 & 45 & 33 & 32 & 36 \\
\hline & & & externá & 343 & 264 & 243 & 251 & 230 \\
\hline \multicolumn{4}{|c|}{ Spolu celkový počet vysokoškolských } & & & & & \\
\hline \multicolumn{4}{|c|}{$\begin{array}{l}\text { študentov na Slovensku } \\
\text { v príslušnom roku }\end{array}$} & 149031 & 137338 & 125453 & 120776 & 117135 \\
\hline
\end{tabular}

(Zdroj: Vlastné spracovanie podl’a údajov zo Štatistických ročeniek Slovenskej republiky v rokoch $2015-2019$ )

Prostredníctvom údajov vo vyššie uvedenej tabul'ke môžeme skonštatovat', že celkový počet študentov študujúcich vybrané študijné odbory pedagogického zamerania na slovenských vysokých školách má v sledovanom rozpätí rokov klesajúcu tendenciu. $\mathrm{V}$ roku 2015 študovalo na Slovensku vybrané študijné odbory pedagogického zamerania 19694 vysokoškolských študentov. Tento počet zároveň predstavoval 13,21 \% zo všetkých študentov, ktorí študovali na slovenských vysokých školách v uvedenom roku. V roku 2016 bol počet študentov študujúcich vybrané smery pedagogického zamerania 
na slovenských vysokých školách 18 159, čo predstavovalo 13,22 \% z celkového počtu vysokoškolských študentov v Slovenskej republike v danom roku. V roku 2017 vo vybraných študijných odboroch pedagogického zamerania študovalo 16964 vysokoškolákov, čo je 13,52 \% z celkového počtu študentov slovenských vysokých škôl v uvedenom roku. V roku 2018 bol počet vysokoškolských študentov študujúcich vybrané smery pedagogického zamerania na slovenských vysokých školách 16509 . Tento počet zároveň predstavoval $13,70 \%$ z celkového počtu študentov študujúcich na slovenských vysokých školách v roku 2018. Posledným sledovaným rokom bol rok 2019. K 31.12. 2019 študovalo vybrané študijné odbory pedagogického zamerania 16422 študentov, čiže 14,02 \% z celkového počtu študentov na slovenských vysokých školách v uvedenom roku. Analýzou zaznamenaných údajov považujeme za potrebné zdôraznit' klesajúci trend $v$ celkovom počte vysokoškolských študentov na slovenských vysokých školách. Avizovaný pokles sa dotýka aj počtu vysokoškolských študentov študujúcich vybrané študijné odbory pedagogického zamerania. Tento pokles je na jednej strane odrazom klesajúcej tendencie celkového počtu vysokoškolských študentov na slovenských vysokých školách, minimálne v predchádzajúcich piatich rokoch. Za jednu z hlavných príčin môžeme považovat' demografickú charakteristiku súčasnej slovenskej spoločnosti. Na Slovensku, rovnako ako vo väčšine európskych krajín, dochádza postupne k starnutiu populácie, a preto sa znižuje aj počet mladých l'udí, ktorí by na základe svojho veku mohli nastúpit' na vysokoškolské štúdium. Rovnako však upozorňujeme aj na to, že vysokoškolské vzdelanie už v súčasnej spoločnosti nepredstavuje záruku uplatnenia sa na trhu práce. Okrem toho, ak sa jednotlivec - vo väčšine prípadov mladý človek rozhodne študovat' na vysokej škole, môžu mu po úspešnom absolvovaní študijného odboru chýbat' praktické skúsenosti požadované $v$ zamestnaní. Z tohto dôvodu znova sústred'ujeme pozornost' na vysokoškolské štúdium študijných odborov pedagogického zamerania. Aj napriek celkovému poklesu počtu vysokoškolských študentov študujúcich študijné odbory pedagogického zamerania $v$ rozpätí sledovaných rokov dochádza zároveň k miernemu nárastu zastúpenia uvedenej skupiny vysokoškolákov v celkovom počte vysokoškolských študentov na Slovensku. Tento nárast je možné zdôvodnit' pretrvávajúcim záujmom mladých l'udí o štúdium smerujúce k príprave na vykonávanie učitel'ského povolania. Zo skúmaných študijných odborov pedagogického zamerania sme zaznamenali najväčší percentuálny nárast počtu vysokoškolských študentov v odbore pedagogické vedy. 8722 študentov $v$ uvedenom študijnom odbore $v$ roku 2015 predstavovalo v percentuálnom vyjadrení 44,29 \% z celkového počtu vysokoškolských študentov študujúcich vybrané študijné odbory pedagogického zamerania na Slovensku. Následne až do konca roku 2019 bol evidovaný mierny nárast percentuálneho zastúpenia vysokoškolských študentov odboru pedagogické vedy za každý jeden sledovaný rok. 7752 vysokoškolských študentov študujúcich študijný odbor pedagogické vedy k 31.12. 2019 predstavovalo 47,20 \% z počtu vysokoškolských študentov skúmaných študijných odborov pedagogického zamerania v uvedenom roku. Študijné odbory pedagogické vedy a učitel'stvo je možné na Slovensku študovat' na verejných aj na súkromných vysokých školách. Štúdium sa realizuje rovnako v dennej, ako aj v externej forme štúdia. Navyše študijný odbor pedagogické vedy ponúka absolventom magisterského stupňa štúdia aj možnost' doktorandského štúdia v dennej aj v externej forme na verejných vysokých školách a od roku 2019 aj v externej forme na súkromných vysokých školách. Od roku 2019 evidujeme študentov doktorandského štúdia v dennej forme aj $v$ študijnom odbore učitel'stvo. Na základe uvedeného chceme zdôraznit' rozmanitost' ponúkaných možností štúdia $v$ uvedených študijných odboroch pedagogického zamerania. Budúci vysokoškolský študent sa môže rozhodnút', v akej forme a na akom type školy chce študovat' vybraný študijný odbor. Možnost' externého štúdia umožňuje vysokoškolským študentom študovat' aj popri zamestnaní, prípadne 
popri inom štúdiu. Rovnako aj možnost' doktorandského štúdia predstavuje pre budúcich absolventov d'alšie možnosti uplatnenia sa v budúcnosti.

Na druhej strane chceme upozornit' aj na počet študentov v študijnom odbore učitel'stvo predmetov $v$ kombinácii. $V$ uvedenom študijnom odbore sme $v$ sledovanom období zaznamenali pokles počtu študentov aj pokles percentuálneho zastúpenia v celkovom počte vysokoškolských študentov vo vybraných študijných odboroch pedagogického zamerania. Zaznamenané zistenia môžeme znova interpretovat' prostredníctvom už vyššie uvedených možností štúdia študijných odborov na vysokých školách na Slovensku. Študijný odbor učitel'stvo predmetov v kombinácii je možné na slovenských vysokých školách študovat' iba na verejných vysokých školách v dennej a v externej forme na I. a II. stupni vysokoškolského štúdia. Podl'a nášho názoru, najmä z tohto dôvodu dochádza v sledovanom období v počte vysokoškolských študentov odborov pedagogického zamerania $\mathrm{k}$ miernemu zvyšovaniu percentuálneho zastúpenia len $\mathrm{v}$ prípade študijných odborov pedagogické vedy a učitel'stvo.

\section{Záver}

Záverom chceme podotknút', že aj napriek rôznym názorom, týkajúcich sa úpadku významu učitel'skej profesie v súčasnej spoločnosti, mladí l'udia majú záujem o štúdium pedagogických študijných odborov. Vykonávaniu povolania učitel'a predchádza pregraduálna príprava na vysokých školách. Aj od jej charakteru závisí rozvíjanie motivácie vysokoškolských študentov reálne vykonávat' uvedené povolanie po ukončení štúdia na vysokej škole. Na základe analýzy dostupných štatistických údajov môžeme skonštatovat', že počas sledovaného obdobia rokov 2015 - 2019 mierne vzrástol percentuálny podiel vysokoškolských študentov študujúcich väčšinu vybraných študijných odborov pedagogického zamerania, ktoré je možné študovat' prevažne $\checkmark$ dennej aj $v$ externej forme štúdia, a to na verejných aj na súkromných vysokých školách na Slovensku. Rozšírené možnosti vysokoškolského štúdia pedagogických študijných odborov predstavujú pre záujemcov o vysokoškolské štúdium možnost' vybrat' si takú formu štúdia, ktorá je najviac vyhovujúca v súvislosti s osobnými alebo aj pracovnými záujmami budúceho vysokoškolského študenta. Okrem toho môžeme predpokladat', že jedným z motivačných faktorov pre štúdium v študijných odboroch pedagogického zamerania je aj záujem podiel'at' sa na výchove a vzdelávaní detí a mládeže prostredníctvom samostatného vedenia edukačného procesu.

Na základe zaznamenaných zistení nášho skúmania musíme poznamenat', že d'alším analyzovaním uvedenej problematiky by bolo potrebné zistit', kol'ko absolventov vysokoškolských študijných odborov pedagogického zamerania má po úspešnom absolvovaní vysokoškolského štúdia reálny záujem vykonávat' učitel'skú profesiu.

\section{Pod'akovanie}

Štúdia bola spracovaná ako súčast' riešenia vedecko-výskumnej úlohy KEGA 015UCM - 4/2018 „Pedagogická prax vysokoškolských študentov s podporou virtuálnej dimenzie.“

\section{Literatúra}

Kasáčová, B. 2004. Zmeny učitel'skej profesie a kontinuálne vzdelávanie učitel'ov. sborník prací filozofické fakulty brněnské univerzity Studia minora facultatis philosophicae universitatis brunensis, 52 (9), 87-99.

Kosová, B. 2005. Profesionalita učitel'a - učitel' ako expert. In Příprava učitelů a aktuální proměny v základním vzdelávaní (s. 102-106). České Budejovice: Jihočeská Univerzita v Českých Budejovicích.

Šmajdová Bušová, K. (2015). Pohl'ad študentov na vlastnú perspektívu uplatnenia sa v pedagogickej profesii po skončení pregraduálneho štúdia. Edukácia. Vedecký a odborný časopis. 1 (15), 253-260. 
Vančíková, K. (2011). Škola a spoločnost'. Kapitoly zo sociológie výchovy. Banská Bystrica: Pedagogická fakulta UMB v Banskej Bystrici.

\section{Adresy autorov}

Doc. Mgr. Mariana Sirotová, PhD.

Katedra pedagogiky, Filozofická fakulta, UCM v Trnave Nám. J. Herdu 2, 91701 Trnava

mariana.sirotova@ucm.sk

Mgr. Veronika Michvocíková, PhD.

Katedra pedagogiky, Filozofická fakulta, UCM v Trnave

Nám. J. Herdu 2, 91701 Trnava

veronika.michvocikova@ucm.sk 


\title{
OSOBNOSŤ PREDŠKOLSKÉHO PEDAGÓGA A JEHO PRÍPRAVA
}

\section{THE PERSONALITY OF A PRESCHOOL (MONTESSORI) TEACHER AND HIS TRAINING}

\author{
Matej Slováček \\ Základná škola, Ruskov \\ Monika Miňová \\ Katedra predškolskej a elementárnej pedagogiky a psychológie, Pedagogická fakulta, \\ PU v Prešove
}

\begin{abstract}
:
The paper deals with the description and analysis of the personality of a kindergarten teacher in the context of the pedagogy of Maria Montessori in the mirror of contemporary educational reality. It describes and analyzes the current educational reality from the point of view of a brain-compatible environment (neuropedagogy and neurodidactics), the NTC system of learning children's brains and effects on the cerebral hemispheres. The personality of a Montessori kindergarten teacher describes through his roles, competencies and virtues, which he holds and has at his disposal in today's concept of education, training and training in kindergarten and with regard to the affiliation of the Montessori approach to human resources theories of education. In the research part, it presents the results and interpretations of the results of a survey conducted in 2020 among graduates of formal education of preschool pedagogy in the Montessori education in Slovakia.
\end{abstract}

\section{Key words:}

pedagogy of Maria Montessori, kindergarten teacher, roles, competencies and virtues of a teacher

\section{Úvod}

Pedagogika Márie Montessoriovej má nezastupitel'né miesto v prístupoch k výchove, vzdelávaniu a výcviku detí najmä predškolského veku. Spolu s pedagogikou R. Steinera, či C. Freineta, predstavuje rokmi overenú, efektívnu a najmä v zahraničí využívanú alternatívu k pre nás tradičnému spôsobu a systému výchovy, vzdelávania a výcviku detí a žiakov. Aj ked' má pedagogika Márie Montessoriovej vo svete vyše storočné korene, na Slovensku (aj v Českej republike...) ide o alternatívu pomerne novú, nakol'ko jednotný školský systém zavedený v týchto krajinách v roku 1948 a trvajúci takmer do konca 20. storočia, neumožnil využívat' vedl'a hlavného prúdu iné alternatívy. Matulčíková (2007) popisuje pedagogiku Márie Montessoriovej ako jednu z najvýznamnejších reformnopedagogických koncepcií $v$ Európe a vo svete. Pedagogické názory Montessoriovej významne ovplyvnili pedagogické koncepcie alternatívnych škôl v druhej polovici 20. storočia a stali sa inšpiráciou moderných alternatívnych škôl, prispeli zároveň aj $\mathrm{k}$ progresu v chápaní detstva a jeho rozvíjania v tradičnej pedagogike. Autorka tejto pedagogickej koncepcie, Mária Montessoriová, bola v roku 2020 časopisom Time zaradená medzi 100 významných žien sveta (www.time.com). „Montessori 
pedagogika/Pedagogika Márie Montessoriovej je pedocentrická, výchovná, vzdelávacia a výcviková koncepcia talianskej lekárky, pedagogičky a myslitel'ky Márie Montessoriovej, ktorá svoju pozornost' orientuje na holistický, nenásilný, humanistický a prirodzený vývin diet'at'a“ (Slováček \& Miňová, 2017, s. 68-69). Cambridgeský slovník psychológie hovorí o metóde Montessori, ktorú popisuje ako prístup k detstvu a základnému vzdelaniu. Diet'a má aktívnu vôlu učit' sa na individuálnej ceste a vo vlastnom tempe, ak je mu daná sloboda konat’ tak, v rámci štruktúrovaného a chráneného prostredia. Individuálna sloboda, zodpovedný výber a praktické limity sú zdôrazňované. Staršie deti sú vyzývané ku kooperatívnym projektom (Matsumoto et al., 2009). The Greenwood dictionary of education (Collins \& O'brien, 2003) ju definuje ako filozofiu a stratégiu výučby založenú Montessoriovou, ktorá pramení z presvedčenia, že deti sa najlepšie učia tým, že robia veci takpovediac „na vlastnú päst““.

\section{Súčasnost' pedagogiky Márie Montessoriovej na Slovensku}

V súčasnosti sa v otázke výchovy, vzdelávania a výcviku detí ku slovu hlási fenomén, ktorý má ambíciu aj perspektívu presahu do budúcnosti. Ide o neuropedagogiku a neurodidaktiku. Neurodidaktika a neuropedagogika sa podla Petláka, Valábika a Zajacovej (2009, s. 11) zaoberajú „vplyvom neurovedeckých poznatkov na pedagogiku a didaktiku a tým, ako môže byt' učenie a vyučovanie týmto poznatkom prispôsobené“. Toto učenie (sa), aby bolo kvalitné, malo by prebiehat' $v$ mozgovo-kompatibilnom prostredí. $\vee$ tejto časti textu priblížime zrkadlenie mozgovo-kompatibilného prostredia $v$ pedagogike Márie Montessoriovej:

- Dôvera - dôveru a pocit istoty a bezpečia zabezpečuje pedagóg/rodič. Deti sa učia vlastným tempom a v súlade s vlastnými potrebami, túžbami, vyplývajúcimi z momentálne aktívneho senzitívneho obdobia, čo predchádza stresu a vyvoláva kladné pocity. $\mathrm{K}$ tomuto samozrejme prispievajú aj rodičia a širšie okolie diet'at'a - pripravené prostredie.

- Sloboda výberu - deti sú v pedagogike M. Montessoriovej slobodné vo výbere aktivity, vo výbere materiálu, v pohybe v priestore i v časovom manažmente. Nie sú nútené pracovat' a učit' sa frontálne, podl'a potrieb dospelého alebo učebných plánov. Učia sa na základe vlastnej motivácie vo vlastnom tempe.

- Zmysluplný obsah - obsah výchovy, vzdelávania a výcviku je členený do piatich štandardných oblastí: Jazyk, Matematika, Kozmická výchova, Zmyslová výchova a Cvičenia každodenného života. Ich obsah je plnohodnotný a významný pre život v spoločnosti.

- Dostatok času - v „Montessori“ škole nezvoní. Organizácia nepodlieha triednohodinovému systému. Diet’a je manažérom svojej práce. Diet’a nie je vyrušované zvonením a vonkajšou organizáciou a nie je prerušené v polarizácii svojej pozornosti. Dokáže plnohodnotne prežívat' svoju prácu a učit' sa vlastným intenzívnym zážitkom a prirodzene vyvíjajúcou sa skúsenost'ou.

- Obohatené prostredie - bohatá ponuka je didaktickým princípom, ktorý hovorí, že prostredie bohatou ponukou nabáda k činnosti. Materiál má byt' usporiadaný tak, aby diet'a povzbudzoval v aktivite a podnecoval jeho záujmy a zvedavost'. Ciel' práce je det'om zrozumitel'ný a viditel'ný.

- Spoluprácu - zabezpečujú aktivity na elipse, práca vo dvojiciach aj spolupráca diet'at'a a dospelého. Diet'a vstupuje do procesu normalizácie prostredníctvom vlastnej práce, tá môže byt' individuálna, alebo skupinová. Spolupráca je otázkou práce, ktorá môže byt' individuálna alebo skupinová. U deti dochádza k situáciam, v ktorých komunikujú nielen s rovesníkmi, ale aj s det'mi mladšími, či staršími. Takéto situácie, rozhovory a dohody nie sú umelo navodené dospelým, 
predstavujú prirodzený život $v$ spoločnosti. Diet’a nerieši životné otázky a problémy „pre edukáciu/pre didaktický ciel“, ale pre jeho reálny život.

- Okamžitá spätná väzba - je zaistená jednou z vlastností materiálu. Kontrola chýb a autokorekcia prispieva k budovaniu samostatnosti, sebavedomia a motivácie.

- Dokonalé zvládnutie naučeného v praktickom živote a neskôr schopnost' učit' iných. K tejto požiadavke na mozgovo-kompatibilné prostredie sa diet'a dostáva opakovaním a pravidelným využívaním v reálnom živote aj mimo školy.

- Cielený pohyb - ruka je nástrojom ducha. Všetko učené a vyučované $v$ pedagogike Montessoriovej prechádza rukami, pohybom. Didaktický montessori materiál rozvíja hrubú aj jemnú motoriku. Cielený, koordinovaný a uvedomovaný pohyb a práca s materiálom stimuluje presnost' a praktickost' aktivity.

Na základe takejto stručnej charakteristiky môžeme konštatovat', že pedagogika Márie Montessoriovej zabezpečuje mozgovo-kompatibilné prostredie, rešpektuje požiadavky na takto definované prostredie, a tým aj mozgovo-kompatibilné učenie (sa). Čiastočnú paralelu s týmito požiadavkami nachádzame aj pri didaktických princípoch tejto pedagogiky: rešpektovanie senzitívnych fáz (období), progresivita záujmov, tvorenie jednoduchých štruktúr, bohatá ponuka, slobodná vol'ba a pohyb, veková primeranost' (Zelinková, 1997).

Dalej sme podobnost' medzi princípmi a činnost'ami v pedagogike Márie Montessoriovej našli aj štúdiom NTC systému učenia (sa), ktorý vychádza z výskumov v oblasti neurológie, medicíny a psychiatrie (Rajović, 2018; Miňová, 2018/2019). Môžeme tvrdit', že výchova, vzdelávanie a výcvik v pedagogike Márie Montessoriovej je efektívnym, zmysluplným a nadčasovým učením (sa), ktoré reflektuje aj požiadavky neuropedagogiky a neurovedy, ako popisujeme vyššie pri mozgovo-kompatibilnom prostredí, čiže je priaznivé k mozgu, učeniu sa. Spoločnými aktivitami NTC systému učenia (sa) a aj pedagogiky Márie Montessoriovej sú: balančné cvičenia (chôdza po elipse), cvičenie jemnej motoriky a grafomotoriky (zapínanie a rozopínanie gombíkov, cvokov, patentov, viazanie mašličiek), skladanie puzzle, stavanie ružovej veže, kreslenie a mal'ovanie, práca $v$ kuchyni, prestieranie stola, príprava jedál, upratovanie, rozpoznávanie abstraktných pojmov (vlajky, planéty, učenie sa písmen), triedenie (živočíchov), zorad’ovanie (hnedých schodov, červených tyčí...), hudobná výchova (zvony...) a podobne.

Dosah a premyslenost' materiálu budeme demonštrovat' cez analýzu materiálu Červenomodré tyče (materiál tvorí desat' červeno-modrých tyčí s odstupňovanou dížkou od desat' centimetrov do sto centimetrov (jeden meter). Každých desat' centimetrov na tyči je zvýraznených striedavo červenou a modrou farbou), vo vzt’ahu k funkciám a využitiu materiálu $v$ kontexte funkcií pravej a l'avej hemisféry mozgu diet'at'a. Aspekty l'avej hemisféry: štruktúry, analýza (z akých tyčí menších ako 10 dokážem vyskladat' počet 10?), poradie, čísla, písmená a hláskovanie (j-e-d-e-n), gramatika a sémantika (popis a pomenovanie tyčí, rozprávanie a rozhovory o nich), syntéza (spájanie častí do celku), logické myslenie (podla Montessori zpravodaj, 2014).

Pedagogika Márie Montessoriovej je nadčasová a aj dnes aktuálna, aj v kontexte víru spoločenských, politických, pedagogických (výchovných) i školských zmien. Zelina (2018) vyjadril tri klúčové oblasti nádeje pre zlepšenie školstva na Slovensku: (1) inovácia vzdelávania - kognitívna nádej, (2) inovácia stratégií a metód autoregulácie a autoregulatívneho učenia sa - behaviorálna nádej, (3) pol'udštenie človeka humanistická nádej. Vo vzt’ahu k predmetnej pedagogike:

- kognitívna nádej - „iné“ kurikulum/obsah, senzitívne fázy diet’at’a, sloboda...

- behaviorálna nádej - zmyslové a zážitkové učenie, práca s chybou, vlastné projektovanie a manažovanie učenia sa a času... 
- humanistická nádej - rešpektovanie ticha, rešpektovanie individuálnej práce spolužiaka, spolupráca, dohoda, uloženie materiálu, koberček, elipsa, starostlivost' o prostredie...Nazdávame sa, demonštrujúc aj v našich prácach (Slováček \& Miňová, 2017; 2019; 2020), že pedagogika Márie Montessoriovej je jednou z možností aj v tomto smere „nádeji“".

Podla Zelinu (2000) mala pedagogika Márie Montessoriovej zastúpenie v Bratislave, kde sa $v$ jednej materskej škole, $v$ jednom oddelení postupovalo podla tejto pedagogiky. Druhou inštitúciou bola $v$ období vzniku publikácie materská škola $v$ Košiciach. $V$ súčasnosti je podla našich analýz, zistení a informácií na Slovensku 11 materských škôl využívajúcich pedagogiku Márie Montessoriovej, z toho 7 je registrovaných v sieti škôl a školských zariadení Ministerstva školstva vedy, výskumu a športu Slovenskej republiky. Platformu základných škôl zastupujú 2 základné školy, obe v sieti škôl a školských zariadení Ministerstva školstva vedy, výskumu a športu Slovenskej republiky. Ďalej sa k tejto pedagogike hlási niekol'ko iných inštitúcií - jaslí, detských a materských centier.

\section{Príprava montessori učitel'a materskej školy}

Učitel' školy v pedagogike Márie Montessoriovej, by mal prejst' dvojakou prípravou. Teoretická príprava je podla Montessoriovej (2001) vel'mi dôležitá a náročná. Budúci učitel' musí sám seba formovat', musí sa naučit' pozorovat', byt' uvážlivým, trpezlivým, prispôsobivým aj vytrvalým. Učitel' má byt' odborne pedagogicky vzdelaný - toto štúdium sa nadobúda na vysokých (stredných) školách, najlepšie $v$ pedagogických študijných programoch, poprípade učitel'ských. Tieto programy obsahujú (mali by obsahovat') pedagogickú, psychologickú, didaktickú aj metodickú prípravu. „Učitelia v materských školách so stredoškolským vzdelaním sú len $v$ niektorých štátoch EÚ - Nemecko, Taliansko. Univerzitné vzdelanie absolvujú učitelia v Grécku, Španielsku, Francúzsku, Írsku, Anglicku, Švédsku, Fínsku, Pol'sku. Ako sme už vyššie spomínali, učitel' materskej školy by mal mat' v budúcnosti minimálne 1 . stupeň vysokoškolského vzdelania (Bc.). Bohužial' táto podmienka sa do zákona o pedagogických zamestnancoch nedostala, preto požadovaným stupňom vzdelania je pre učitel'a materskej školy aj vysokoškolské vzdelanie prvého stupňa alebo úplné stredné odborné vzdelanie“ (Miňová, 2019). Nádej prináša „Plán obnovy“ a jeho možná implementácia do školskej politiky vo vzt’ahu k vysokoškolskej kvalifikácii učiteliek materských škôl.

Druhou čast'ou prípravy Montessori učitela je príprava v oblasti Montessoriovej pedagogiky. Učitel' musí byt' schopný vybrat' vhodný materiál, predviest' jeho používanie. Musí poznat' didaktický materiál aj zásady a teoretickú platformu pedagogiky Márie Montessoriovej. Učitel' diet'a neučí, diet’a sa učí samo. Vedie ho na ceste životom, usmerňuje jeho psychickú aj fyzickú aktivitu. Táto príprava môže byt' formálna, neformálna aj informálna. K formálnemu, neformálnemu aj informálnemu vzdelávaniu učitel'ov, aj študentov - budúcich učitel'ov materských škôl v pedagogike Márie Montessoriovej sme aj my publikovali niekol'ko textov (Slováček, 2015, Slováček \& Miňová, 2019; 2020 a iné.)

V tomto príspevku sa chceme venovat' ich rolám, ktoré dnes učitelia zastávajú, kompetenciám, ktorými musia disponovat' a cnostiam, ktoré sú špecifické pre montessori učitel'ov. Tieto roly, kompetencie aj cnosti odzrkadl'ujú potreby dnešných detí, rodičov aj spoločnosti, ktoré sa rokmi menia, a preto aj my odborníci musíme na ne reagovat'.

\section{Roly, kompetencie a cnosti montessori učitel'a materskej školy}

Učitel' $v$ praxi vstupuje $v$ procese profesijnej dráhy do rôznych rolí. Tie sa postupne doplňajú v závislosti s meniacou sa spoločnost'ou. Spomenieme tie najelementárnejšie vyplývajúce z pedagogickej praxe a zahrňujúce primárne dimenzie učitel'a materskej školy. Roly učitel'a/učitel'ky budeme popisovat' z pohl'adu Miňovej (2014, s. 60-61) v doplnení a komparácii so Syslovou (2017), ktoré ich formulovali na základe svojho 
poznania, skúsenosti, dlhoročnej praxe a výsledkov vedecko-výskumného pôsobenia v oblasti pedagogiky a predškolskej pedagogiky na Slovensku a v Českej republike. Roly učitel'a materskej školy sú podla nášho názoru nie odlišné, až totožné s rolami učitel'a v pedagogike Márie Montessoriovej. Predmetná pedagogika vznikala a priori s det'mi predškolského veku a dnes je vo väčšine prípadov v práci s týmito det'mi uplatňovaná.

- Rola facilitátora: učitel' je akýmsi sprievodcom diet'at'a na ceste za poznaním, rozvíja jeho možnosti prostredníctvom jeho vlastnej aktivity a vlastnej činnosti. Vedie diet'a k tomu, aby na základe svojich rozvojových možností dosiahlo vlastný a v danej chvíli maximálne možný rozvoj. Pomáha pri príprave prostredia, príprave vhodných pracovných podnetov, či pri samotnej práci, ked' ho o to dieta poprosí.

- Rola opatrovatel'a: nemala by byt' podceňovaná, ani preceňovaná, ani zosmiešňovaná. Taktiež nemôže byt' jediná, lebo ňou nie je profesia učitel'a vyčerpaná. Učitel' zastupuje na chvílu matku i otca v dobe ich neprítomnosti a prejavuje diet'at'u preukázatel'ný cit. Je empatický k detskej potrebe bezpečia, lásky a úcty. Zložitost' roly spočíva v tom, že empatickost' prejavuje vo vzt'ahu $\mathrm{k}$ diet'at'u a k jeho vlastnej rodine - nemôže spochybňovat' matku ani otca. Aj v pripravenom a podnetnom prostredí potrebuje diet'a oporu, pocit istoty a bezpečia, tieto mu dodáva aj dospelý.

- Rola komunikátora: učitel' by mal vediet' komunikovat' na úrovni danej situáciám, ktoré sa vyskytujú v škole. Je spôsobilý počúvat', odpovedat', reprodukovat', nadväzovat' vzt'ah s det'mi, rodičmi, kolegami, inými zamestnancami školy a verejnost'ou. Komunikuje tak, aby rodičia mali záujem spolupracovat' a nevyvoláva pocit nevôle, vnucovania sa a zasahovania do ich práv. Pre učitel'a nie je l'ahké byt' partnerom v komunikácii s rodičmi, det'mi, kolegami a učitel'mi z iných škôl. Preto učitel' by mal byt' vybavený vedomost'ami, spôsobilost'ami, zručnost'ami, vlastnou osobnou vyzretost'ou a vyrovnanost'ou.

- Rola učitel'a: očakáva sa, že učitel' pomáha diet'at'u spoznávat' svet okolo nás i seba v tomto svete, učí diet'a žit', učit' sa, konat'. Navodzuje prirodzené i modelové ( $v$ predmetnej pedagogike minimálne) situácie kde diet’a získava a osvojuje si klúčové kompetencie pre život. Učitel' vykonáva d'alšie dôležité činnosti: pozoruje - diagnostikuje, plánuje, projektuje a programuje edukačnú činnost', motivuje a hodnotí. Učitel' je skúsený a poučený pozorovatel', ktorý učí diet'a bud' priamo rozhovorom, svojou vzorovou prácou $v$ rámci $v$ tejto pedagogike uplatňovanej aktívno-reproduktívnej metodiky. Učitel' je pasívnejší a diet'a je aktívne. Reprodukuje činnost' podla modelu, praktizuje a vykonáva činnost' podl'a vzoru. Ide o systém trénovania a o uzavreté praktizovanie na základe trvalých alebo vopred vytvorených modelov, schém a kritérií (Kostrub, 2008). Aj nepriamo, a to konkrétne prípravou prostredia, materiálu a situácií komunikácie a experimentovania, doplñaním a variovaním detskej knižnice.

- Rola vodcu: objavuje sa tam, kde je potrebné organizovat' väčší počet účastníkov pedagogických procesov. Napríklad počas aktivít na elipse, alebo počas vychádzky, exkurzie a podobne. $V$ role vodcu sa učitelia škôl objavujú pomerne často práve pri spolupráci s rodinou, pri dobrovol'nej spolupráci s d'alšími inštitúciami v obci (športové a kultúrne organizácie). Bez vodcovských osobností sa škola nezaobíde ani v období plánovaných zmien, ani v období, ked’ škola pracuje podla zabehnutých systémov.

- Rola manažéra: mali by sme si uvedomit', že aj učitelia uskutočňujú vel'a prvkov z riadiacej práce - plánujú, organizujú, realizujú, kontrolujú a hodnotia všetky uskutočnené aktivity $v$ podmienkach im najbližších, najznámejších, v podmienkach svojej vlastnej triedy. Manažment „montessori“ učitel'a spočíva 
najmä $v$ už spomínanom manažovaní pripraveného prostredia, či už jeho zariad’ovaním, alebo obmieňaním, či plánovaním aktivít.

- Rola obhajcu: v súčasnej dobe a v našom živote je zvyšujúci sa výskyt sociálnych deviácií, neplnenie si rodičovských povinností, zanedbávanie základných potrieb, týranie a zneužívanie detí, a to si vyžaduje viac pozornosti venovanej ochrane detí, ktoré žijú v nevhodnom prostredí. Správne poučený učitel' školy môže zachytit' signály dokazujúce nesprávne uspokojovanie potrieb diet'at'a, porušovanie práv diet'at'a a urobit' kroky k náprave.

- Rola poradcu: škola, okrem iných funkcií, plní aj funkciu poradenskú. Učitelia škôl by mali disponovat' aj poradenskými kompetenciami. V školách sú často stanovené konzultačné hodiny pre rodičov, v ktorých sa často učitel' dostáva do roly poradcu. Cesta k poradenstvu je stupňovitá, dlhodobá, vyžaduje si zodpovednost', schopnost' vyrovnávat' sa s náročnými situáciami. Učitelia, ktorí vzbudili dôveru rodičov, sú najmä morálne oceňovaní za úspešné vedenie diet'at'a. Najmä, ak ide o tak špecifickú pedagogickú koncepciu, kde je obzvlášt' žiaduce a potrebné, aby škola a rodinná výchova boli jednotní. Aby sa diet’a nedostávalo do konfliktu prístupov vo výchove, vzdelávaní a výcviku v školskom aj rodinnom prostredí.

- Syslová (2017) uvádza aj rolu administrátora: Učitel' vedie povinnú dokumentáciu, ale i dokumentáciu z diagnostickej činnosti formálne i obsahovo vo vysokej kvalite, lebo si uvedomuje, že dokladuje jeho odbornú úroveň a kvalitu výchovy, vzdelávania a výcviku, ktoré poskytuje.

Aby mohol učitel' zastávat' tieto roly, musí prejst' vyššie spomenutou odbornou prípravou. Na základe nej a následného adaptačného vzdelávania a d’alšieho profesijného rozvoja nadobúda kompetencie, ktoré definujú jeho profesionalitu a odbornost'. Delení a definovaní kompetencií učitel'a je niekol'ko, tie sú závislé od odborného profilu autora a od ciel'ovej skupiny pre ich definovanie. Kompetencie učitel'a chápeme ako súbor schopností a spôsobilostí vykonávat' úspešne učitel'skú profesiu (Průcha \& Kotátková, 2013). V posledných rokoch sa vel'mi často hovorí o kompetenciách učitel'a. Rôzni autori, ako napríklad Kasáčová (2004), Turek (2003), Petlák (2002/2003), Švec (1998), Helus (1995) a iní sa zaoberajú kompetenciami učitel'ov. Každý z nich má svoje delenie, ale v základných bodoch sa zhodujú a prelínajú. Hupková a Petlák (2007) popisujú tieto učitel'ské kompetencie: komunikačné, odborno-pedagogické, didakticko-metodické, autokreatívne, interakčné, poznávacie, interpretačné, realizačné, ochranné, asertívne, negosociačné, facilitátorské, morálne, kooperatívne, organizátorské, informačnomediálne, tvorivo-autorské. Pre učitel'a materskej školy upravili a definovali kompetencie Guziová, Podhájecká, Kimličková (2011) a menujú tieto: personálne, interpersonálne, komunikatívne, kognitívne, učebné, informačné, sebarozvíjajúce a kompetenciu promptného, akčného reagovania na novú pedagogickú situáciu.

Pre potreby tohto príspevku sme si vybrali kompetencie podla Helusa (1995). Tieto si študenti osvojujú počas formálneho štúdia systematicky $v$ jednotlivých predmetoch $v$ priebehu niekol'kých rokov a pravidelne si ich overujú počas pedagogickej praxe. Ide o kompetencie odborno-predmetové, psychologické, pedagogicko-didaktickopsychologické, komunikatívne, riadiace, poradensko-konzultatívne, plánovat' a projektovat' edukačnú prácu s det'mi.

Učitel' v pedagogike Márie Montessoriovej musí disponovat' všetkými vyššie spomenutými, tradične uznávanými a všeobecne platnými kompetenciami. Avšak špecifickost' a inakost' výchovy, vzdelávania a výcviku v intenciách pedagogiky Márie Montessoriovej nás núti zamýšl'at' sa a navrhovat', formulovat' d'alšiu, novú a špecifickú kompetenciu MM-kompetenciu (MM = Mária Montessoriová), ktorú definujeme ako súhrn vedomostí a poznatkov o pedagogike Márie Montessoriovej, schopností realizovat' 
výchovu, vzdelávanie a výcvik podla Márie Montessoriovej a vnútorné presvedčenie a zžitie sa s filozofiou a myšlienkami Márie Montessoriovej. Z tejto definície môžeme dedukovat' tri dimenzie: (1) poznatkovú, (2) praktickú a (3) emocionálnu.

- Poznatková dimenzia obsahuje vedomosti a poznatky v teórii pedagogiky Márie Montessoriovej. Učitel' v tejto pedagogike by mal poznat' podmienky vzniku tejto pedagogiky aj jej didaktiku, vzt’ah k iným vedám (pedagogika, didaktika, psychológia, diagnostika, manažment, kreatológia, pedeutológia...), filozofické názory Márie Montessoriovej aj ciele a obsahové zameranie tohto prístupu.

- Praktická dimenzia vyžaduje poznanie a metodické ovládanie činností a práce s montessori materiálom, jeho charakteristiky aj ciele. Učitel' by mal poznat' potreby detí, primerané aktivity aj prakticky ovládat' diagnostikovanie diet'at'a.

- Emocionálna dimenzia: pedagogika a prístup k det’om, výchove, vzdelávaniu a výcviku podla Márie Montessoriovej má svoje špecifiká. Autorka definovala a vyslovila niekol'ko myšlienok a názorov, ktoré kreujú jej prístup. Je dôležité byt's nimi oboznámený a stotožnený. Učitel' v pedagogike Márie Montessoriovej musí byt' s jej filozofiou zžitý. Musí mu byt' vlastný holistický a zážitkový prístup vo vyučovaní, prirodzená interakčná teória rozvoja diet'at'a. Rovnako je žiaduce byt' stotožnený s progresivistickou filozofiou a personalistickými teóriami výchovy. Súčast'ou je aj poznanie výskumov týkajúcich sa tejto pedagogiky a ich výsledkov.

„Učitel' v pedagogike M. Montessori musí byt' človek, ktorý túto filozofiu pozná, musí mat' naštudované jej teoretické práce, ale to nestačí. Učitel', ak chce byt' „Montessori učitel'om", musí byt' s touto pedagogikou, filozofiou a s myšlienkami Márie Montessori vnútorne stotožnený“ (Slováček \& Miňová, 2015, s. 147). Vyplývajúc z príslušnosti k personalistickýcm teóriám výchovy, aj zo vzt’ahu edukátora a edukanta je potrebné zamýšl'at' sa aj nad osobnostnými (emocionálnymi) kvalitami učitel'a v pedagogike Márie Montessoriovej. Aký má byt' učitel' v pedagogike Márie Montessoriovej? Na túto otázku dáva jednoduchú a jasnú odpoved' Rýdl (2007, s. 51): Učitel' v predmetnej pedagogike musí mat' cnosti, ktoré ich vnímaví zverenci, vyvíjajúce sa a osobnost' rozvíjajúce deti môžu napodobňovat'. Tieto cnosti sú: sebavedomie, stálost', láskavost', št'astie, húževnatost', idealizmus, oddanost', spol'ahlivost', vyrovnanost', odvaha, záujem, trpezlivost', ohl'aduplnost', priatel'skost', vernost', odhodlanie, vel'korysost', zl'utovanie, disciplína, poctivost', úprimnost', nezlomnost'.

V prejave v Barcelone v roku 1933 Montessoriová (In: Everhardtová, 2000, s. 48, Rýdl, 2007) formulovala dvanást' pokynov, požiadaviek pre učitel'a: 1. Učitel' musí vytvorit' pripravené prostredie a starat' sa oň. 2. Učitel' musí sám ovládat' používanie didaktického materiálu a vediet' det'om sprostredkovat' jeho používanie. 3. Učitel' je aktívny, ked' sprostredkúva diet'at'u vzt'ah s okolím a pasívny, ked' už diet'a vzt'ah nadviaže. 4. Učitel' musí diet'a nepretržite diagnostikovat', aby vedel pomôct' v okamihu, kedy je o pomoc požiadaný. 5. Učitel' musí pomôct', ked' je o pomoc požiadaný diet’at'om. 6 . Učitel' musí vediet' počúvat' a pýtat' sa. 7 . Učitel' musí rešpektovat' diet'a, jeho prácu a nerušit' ho. 8. Učitel' musí rešpektovat' chyby diet'at'a. 9. Učitel' musí rešpektovat' diet'a, ktoré odpočíva a pozoruje pracujúce deti, nenútit' ho do práce. 10. Učitel' sa musí pokúšat' diet’a nadchnút' pre prácu s materiálom. 11. Učitel' musí nechat' diet'at'u pocit, že sa na jeho pomoc môžu spol'ahnút', nesmie ale svoju pomoc vnucovat'. 12. Učitel' musí diet'at'u, ktoré dokončilo aktivitu ponúknut' seba (svoju dušu).

Aj týmito rolami, kompetenciami a cnost'ami môžeme definovat' „montessori“ učitela. Ako sa cítia byt' absolventi stredných a vysokých škôl pripravení v jednotlivých kompetenciách? Venovali sa počas svojej prípravy alternatívnym prístupom v edukácii a pedagogike Márie Montessoriovej? Bola ich príprava $v$ predmetnej pedagogike viac teoretická, či praktická? Zaujala ich pedagogika Márie Montessoriovej? Čím je podl'a nich 
táto pedagogika zaujímavá? Aj tieto otázky si musíme klást' v dnešnej dobe, kedy je využívanie alternatívnych prístupov žiaduce, či už z dôvodov narastajúcich počtov detí s odkladom povinnej školskej dochádzky, detí s individuálny vzdelávací program, detí odkázaných na pedagogických asistentov, či na vysoko individuálny prístup a iné ako frontálne tradičné metódy a prístupy. Pluralitné prístupy, rôznorodé stratégie, hl'adanie toho, čo vyhovuje tomu ktorému diet'at'u/žiakovi, poznanie a aplikovanie do praxe prístupov, ktoré majú svoje opodstatnenie a overené „účinky“, poznanie nielen nových trendov, ale aj poznatkov a aktuálnych informácií o mozgu (neurovedy, neuropedagogika a didaktika, kognitívna pedagogika a kognitívna edukácia...) ... to všetko podl'a nás patrí k učitel'ovi 21. storočia, a nielen okrajovo, informatívne. Príprava učitel'ov predprimárneho a primárneho vzdelávania ( $v$ súčasnosti ich prípravu zabezpečujú vysoké školy $v$ študijnom odbore Učitel'stvo a pedagogické vedy a študijné programy (Bc.), napr. Predškolská a elementárna pedagogika a (Mgr.) Učitel'stvo pre primárne vzdelávanie a Predškolská pedagogika a stredné školy $v$ odbore Učitel'stvo pre materské školy a vychovávatel'stvo), aj vo vzt'ahu k alternatívnemu školstvu je predmetom nášho záujmu dlhodobo. Naše analýzy ukazujú, že obsahy vysokoškolských predmetov sú predimenzované, často sa predmety spájajú, kumulujú a časové kapacity semestrálnych predmetov musia obsiahnut' neúmerné množstvo učiva a najmä tém. Otáznym je aj proces výberu študentov pedagogiky a učitel'stva na Slovensku. Jeden z aspektov nami načrtnutého problému nastolila aj Podhájecká (2014). (1) „V súčasnosti kvalitu výuky ohrozuje aj tlak na znižovanie študijných nárokov pre študenta. Na jednej strane nás teší vysoký záujem uchádzačov o štúdium predškolskej a elementárnej pedagogiky, no na druhej strane masová výuka prináša aj isté úskalia. Za 20 rokov (od roku 1974 až 1995), kedy boli smerné čísla pre prijatie počtu študentov na tento odbor, vtedy neštruktúrovaného štúdia, ukončilo 233 absolventov. V akademickom roku 2014/2015 v 1. ročníku bakalárskeho štúdia evidujeme 381 študentov, z toho na dennej forme 252 študentov a na externej forme 139 . V seminárnych skupinách sú pomerne vysoké počty študentov. Štruktúrované štúdium odboru Predškolská pedagogika by sa malo vrátit' k neštruktúrovanému štúdiu. Je to degradovanie tohto štúdia prevažne na bakalársku úroveň a bez absolvovania prijímacích skúšok" (Podhájecká, 2014, s. 56). Druhým aspektom hodným zamyslenia je (2) pomer a zastúpenie vyučovaných predmetov v príprave učitel'ov primárneho vzdelávania, resp. tendencie ich zmien (Portik, 2014):

Tab. 1: Prehl'ad v oblastiach poznania v jednotlivých akademických rokoch

\begin{tabular}{|l|c|c|c|c|c|}
\hline Skupiny predmetov & $\mathbf{1 9 4 6 / 4 7}$ & $\mathbf{1 9 6 7 / 6 8}$ & $\mathbf{1 9 8 0 / 8 1}$ & $\mathbf{1 9 9 8 / 9 9}$ & $\mathbf{2 0 1 4 / 1 5}$ \\
\hline Všeobecný základ & 16 & 16 & 16 & 7 & $3 / 0$ \\
\hline Pedagogicko-psychologické & 33 & 23 & 14 & 16 & $24 / 16$ \\
\hline Biologicko-pediatrické & 9 & 2 & 8 & 1 & $3 / 0$ \\
\hline Všeobecno-predmetové & 34 & 40 & $40 / 8$ & 69 & $41 / 66$ \\
\hline prax & 8 & 16 & 10 & 9 & $14 / 18$ \\
\hline
\end{tabular}

(Zdroj: Portik, 2014)

V tabul'ke 1 je uvedené a zretel'nejšie v grafe 1, že percentuálne zastúpenie predmetov všeobecného základu, biologicko-pediatrických a všeobecno-predmetových klesá. 


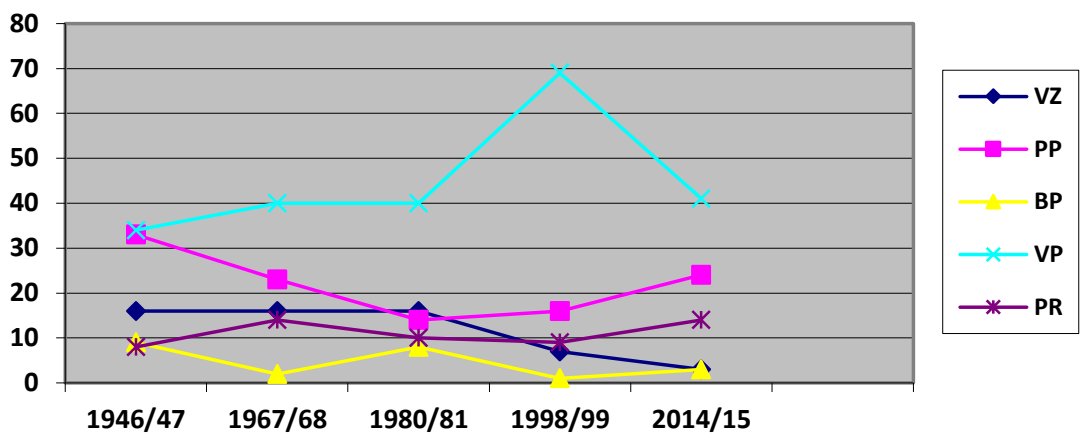

Graf. 1: Zmeny v štruktúre zloženie študijných predmetov

Legenda: VZ - všeobecný základ, PP - pedagogicko-psychologické predmety, BP biologicko-pediatrické predmety, VP - všeobecno-predmetové predmety, PR - prax

Tieto vyššie menované fenomény, (1) zvyšujúci sa počet študentov a (2) znižujúci sa počet predmetov (charakteru všeobecného základu, biologicko-pediatrického i všeobecno-predmetového, ako aj d’alších - z dlhodobého hl'adiska) okrem praxe, ako aj osobná skúsenost' vyplývajúca z pozície vysokoškolskej učitel'ky, nám naše tvrdenie potvrdzuje. Spomeňme prieskum, ktorý sme realizovali v akademickom roku 2003/2004 (Miňová, 2012). Na otázku „Či splnila vysoká škola u študentov ich očakávanie?“ uvádzame autentické výpovede študentov z roku 2003/2004, ktoré patria do kognitívnej a emocionálnej oblasti absolventa: naučila ma nájst' si systém v učení, naučila ma pochopit' myslenie a cítenie detí, naučila ma milovat' knihy a knižnice, získala som vel'a odborných, teoretických poznatkov, vedomostí. V čom nie, neodpovedali 4 respondenti a 7 odpovedalo. Odpovede boli formulované nasledovne: (1) mala som vyššie očakávania (bez konkretizácie), (2) málo praxe, (3) málo praktických cvičení pre diferencovanú prácu $v$ materskej škole. Na porovnanie uvádzame názory externých študentov. Na túto otázku až $21,7 \%$ respondentov vôbec neodpovedalo. Na otázku v čom áno, odpovedalo 13 respondentov a 10 neodpovedalo. Ich odpovede sa týkali najmä kognitívnej oblasti absolventa: rozšírila mi poznatky z oblasti predškolskej pedagogiky, získala som rozhl'ad, prispela k skvalitneniu mojej odbornosti. Na otázku v čom nie, vyjadrilo sa 11 respondentov a 12 sa nevyjadrilo. Zistenie: málo konkrétnych praktických hodín, málo konzultácií, vel'a všeobecných predmetov a predimenzované učivo, málo priestoru venovaného didaktikám predmetov, v niektorých predmetoch slabé prepojenie teórie $\mathrm{s}$ praxou, v prístupe vyučujúcich (bez bližšieho komentára). Podobné zistenia nachádzame v prieskume, ktorý realizoval Portik (2002, s. 184), kde študenti taktiež navrhujú viac sa venovat' didaktikám predmetov.

Najnovšie poznatky často absentujú, neuropedagogika a kognitívna pedagogika sa implementujú do študijných plánov pomaly, alternatívne pedagogické koncepcie sú vyučované informačne, niekedy na pozadí iných takisto dôležitých tém, čo však $v$ žiadnom prípade nekladieme za vinu vyučujúcim, možno školskej politike, či vysokoškolskému systému ako takému $v$ príprave budúcich učitel'ov. Alternatívne pedagogické systémy sú nevyhnuté $v$ demokratickej, humanistickej a pluralitnej edukačnej praxi a školskej politike. V súčasnosti narastá na Slovensku počet materských škôl, ktoré uplatňujú didaktiku a princípy Márie Montessoriovej na úrovni didaktickej praxe, i na úrovni jej implementácie do školských vzdelávacích programov, čo je podporené výsledkami experimentálneho overovania, z ktorého vyplynulo schválenie uplatňovania pedagogickej koncepcie Marie Montessori a jej prvkov vo výchovno- 
vzdelávacom procese $v$ predprimárnom vzdelávaní v materských školách, zaradených v sieti škôl a školských zariadení Slovenskej republiky. Preto si myslíme, že absolventi vysokých (aj stredných škôl), ktorí získajú kvalifikáciu na výkon svojej profesie, by mali byt' najmenej $v$ základoch pripravení na prácu aj $v$ takto orientovaných materských školách. Aj prax nás presviedča nielen o opodstatnenosti iniciatívneho neformálneho a informálneho vzdelávania ale niekedy aj o akejsi nedostatočnosti formálneho vzdelávania, aj napriek štandardnej dížke štúdia (Bc. - 3 roky, Mgr. - spolu 5 rokov, maturita - spravidla 4 roky, pri pomaturitnom štúdiu - 2 roky). Nedostatočnost' formálneho vzdelávania nevidíme $v$ nutnosti d’alšieho vzdelávania sa (profesijného rozvoja), čo je prirodzenou súčast'ou nielen učitel'ského povolania, ale najmä $v$ minimálnej pripravenosti na začiatok profesijného rozvoja $v$ oblasti, napr. alternatívnych spôsobov edukácie. Pre ilustráciu uvádzame informáciu k predmetu Súčasné trendy v edukácii (Prešovská univerzita v Prešove - Mgr. - Predškolská pedagogika). Počas semestra je problematike venovaná 1 vyučovacia hodina $v$ podobe prednášky aj seminára (Slováček \& Miňová, 2020). Aj ked' máme na Slovensku (aj v Českej republike) realizovaných niekol'ko kurzov a vzdelávaní v oblasti pedagogiky Márie Montessoriovej, nie vždy sú finančne, ale aj časovo dostupné. (O týchto možnostiach a ich špecifikách bližšie v Slováček \& Miňová, 2020). Pre ilustráciu spomeňme v akých sumách sa pohybujú „dostupné“ vzdelávania. Cena za vzdelávanie Slovenskej asociácie Montessori je 1610 EUR. Prvý diplomovaný kurz Montessori pedagóg ZŠ, pozostávajúci z troch samostatných ročných úrovní, cena jednej úrovne je 1490 EUR, organizátor Občianske združenie Monte plus, Bratislava (www.monteplus.sk). Zaujímavým, dostupným neformálnym vzdelávaním v oblasti pedagogiky Márie Montessoriovej sú vzdelávacie semináre vedené MVDr. Evou Štarkovou aj v Českej republike, aj na Slovensku. Vzdelávanie prebieha formou 8 hodinových stretnutí podla zamerania modulov. Jeden modul, jeden seminár stojí 33 EUR a obsahom je stručná teória a najmä praktické ukážky práce s materiálom, zážitkové učenie účastníkov a metodický materiál k oblasti. Ak by začínajúci pedagóg chcel absolvovat' celé vzdelávanie = 330 EUR.

\section{Metodika prieskumu}

V roku 2020 sme dotazníkom realizovali prieskum medzi absolventkami vysokoškolského (Bc. a Mgr.) a stredoškolského pedagogického štúdia (programy: Predškolská a elementárna pedagogika (Bc.), Predškolská pedagogika (Mgr.), Učitel'stvo pre materské školy a vychovávatel'stvo (ÚSO) - pomaturitné štúdium škôl na východnom Slovensku (Košice, Prešov). Dotazník sme distribuovali digitálnou formou prostredníctvom e-mailovej komunikácie. Použili sme neštandardizovaný dotazník, ktorý obsahoval 18 položiek, z toho 5 zatvorených, 5 otvorených a 8 posudzovacích škál. Ciel'om prieskumu bolo zistit' na základe sebareflexie absolventiek vysokoškolského a stredoškolského štúdia ich názory na: a) osvojené pedagogické a odborné kompetencie, b) kompetencie, ktorým je potrebné sa ešte komplexnejšie venovat', c) kontakt absolventov počas štúdia s predmetmi o alternatívnych koncepciách, d) kontakt s koncepciou Márie Montessoriovej a aký majú na ňu názor. Čast' výsledkov prieskum dávame do porovnania s výsledkami nášho dlhodobého záujmu - približne desat' rokov sa venujeme prieskumu zameranému na zistenie názorov študentov ako sa cítia byt' pripravení v jednotlivých profesijných kompetenciách (Miňová, 2019). Do prieskumu sa zapojilo 45 absolventiek. Najviac dotazníkov odovzdali absolventky prvého stupňa vysokoškolského štúdia $(n=29)$, absolventky druhého stupňa $(n=8)$ a pedagogickej a sociálnej akadémie $(n=8)$ odovzdali dotazníky v totožnom počte. 


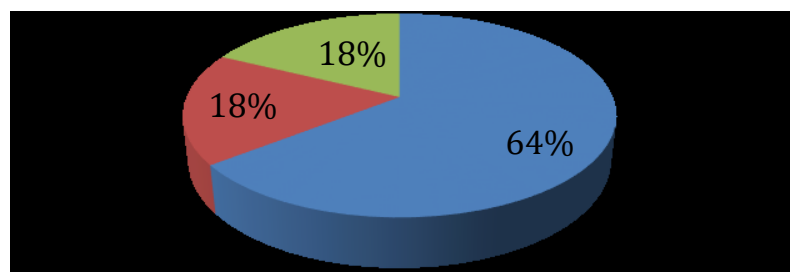

$\square \mathrm{Bc}$.

agr.

- ÚSO

Graf. 2: Zloženie súboru prieskumu $(n=45)$

Tab. 2: Kompetencie absolventov

\begin{tabular}{|c|c|c|c|c|c|c|c|c|c|c|c|c|c|c|c|}
\hline & \multicolumn{12}{|c|}{ výborne } & \multicolumn{3}{|c|}{ nedostatočne } \\
\hline & \multicolumn{3}{|c|}{1} & \multicolumn{3}{|c|}{2} & \multicolumn{3}{|c|}{3} & \multicolumn{3}{|c|}{4} & \multicolumn{3}{|c|}{5} \\
\hline & Bc. & Mgr. & úso & Bc. & Mgr. & Úso & Bc. & Mgr. & Úso & Bc. & Mgr. & ÚSO & Bc. & Mgr. & Úso \\
\hline & \multicolumn{15}{|c|}{$\%$} \\
\hline ODP & 27,5 & 50 & 0 & 55,1 & 12,5 & 37,5 & 13,7 & 37,5 & 37,5 & 3,4 & 0 & ODP & 27,5 & 50 & 0 \\
\hline PS & 41,3 & 25 & 12,5 & 34,4 & 37,5 & 25 & 20,6 & 37,5 & 50 & 3,4 & 0 & PS & 41,3 & 25 & 12,5 \\
\hline PDP & 31 & 50 & 12,5 & 51,7 & 25 & 25 & 6,8 & 12,5 & 37,5 & 10,3 & 12,5 & PDP & 31 & 50 & 12,5 \\
\hline KOM & 31 & 62,5 & 12,5 & 27,5 & 12,5 & 25 & 27,5 & 0 & 37,5 & 13,7 & 12,5 & KOM & 31 & 62,5 & 12,5 \\
\hline RD & 13,7 & 25 & 0 & 51,7 & 37,5 & 12,5 & 13,7 & 25 & 75 & 17,2 & 0 & RD & 13,7 & 25 & 0 \\
\hline PK & 10,3 & 25 & 12,5 & 31 & 50 & 0 & 37,9 & 12,5 & 75 & 17,2 & 12,5 & PK & 10,3 & 25 & 12,5 \\
\hline PLPR & 44,8 & 50 & 12,5 & 37,9 & $\overline{12,5}$ & 37,5 & 10,3 & 25 & 37,5 & 6,8 & 0 & \begin{tabular}{|l|} 
PLPR \\
\end{tabular} & 44,8 & 50 & 12,5 \\
\hline
\end{tabular}

Legenda: ODP - odborno-predmetové kompetencie, PS - psychologické kompetencie, PDP - pedagogicko-didakticko-psychologické kompetencie, KOM - komunikatívne kompetencie, RD - riadiace kompetencie, PK - poradensko-konzultatívne, PLPR kompetencie plánovat' a projektovat' prácu s det'mi.

V Tab. 2 uvádzame odpovede absolventov všetkých troch stupňov získania kvalifikácie podla vyhlášky č. $1 / 2020$ Z. z. o kvalifikačných predpokladoch pedagogických zamestnancov a odborných zamestnancov. Podla tejto vyhlášky na Slovensku nadobúda učitel' materskej školy kvalifikačné predpoklady absolvovaním príslušných škôl a získaním vysokoškolského vzdelania druhého stupňa, vysokoškolského vzdelania prvého stupňa, alebo úplného stredného odborného vzdelania.

Absolventi štúdia na úrovni úplného odborného vzdelania sa cítia vo všetkých kompetenciách pripravení na úrovni 3 našej hodnotiacej škály, teda na priemernej úrovni. Vidíme tu potrebu kvalitného adaptačného vzdelávania a pozitívnu prognózu vo vzt’ahu k smerovaniu odpovedí smerom k úrovni výborne a nie naopak. Absolventi prvého stupňa vysokoškolského vzdelávania sa najviac cítia pripravení v kompetenciách plánovat' a projektovat' prácu s det'mi, komunikatívnych a psychologických kompetenciách. Absolventky druhého stupňa vysokoškolskej prípravy sa najpripravenejšie cítia $v$ kompetenciách odborno-predmetových, pedagogicko-didakticko-psychologických, komunikatívnych a kompetenciách plánovat' a projektovat' prácu s det'mi.

Pozitívnym zistením u všetkých troch skupín respondentiek je, že ani pri jednej kompetencii neprevažuje negatívna tendencia odpovedí. To sme naznačili aj 
zvýraznením najvyšších percentuálnych hodnôt v jednotlivých skupinách pri jednotlivých kompetenciách.

Miňová (2019) publikuje pri inej metodike vyhodnotenie prieskumu takéto výsledky: Interní študenti sa najlepšie cítia byt' pripravení v odborno-predmetových kompetenciách $(65,7 \%)$ a nedostatočne $v$ riadiacich $(24,5 \%)$ a poradensko-konzultatívnych $(18,2 \%)$. Študenti externej formy štúdia toho istého odboru majú najlepšie osvojené odbornopredmetové kompetencie $(56,7 \%)$ a najmenej riadiace $(34,5 \%)$ a poradenskokonzultatívne $(25,4 \%)$.

Tab. 3: Alternatívne pedagogické smery v obsahu štúdia

\begin{tabular}{|c|c|c|c|c|c|c|}
\hline \multirow{2}{*}{} & \multicolumn{2}{|c|}{ Bc. } & \multicolumn{2}{c|}{ Mgr. } & \multicolumn{2}{c|}{ ÚSO } \\
\cline { 2 - 7 } & áno & Nie & áno & nie & áno & nie \\
\cline { 2 - 7 } & \multicolumn{7}{|c|}{$\%$} & \multicolumn{2}{c|}{} \\
\hline ALT & 100 & 0 & 100 & 0 & 87,5 & 12,5 \\
\hline MMPG & 96,55 & 3,44 & 100 & 0 & 75 & 25 \\
\hline zaujala ma MM & 96,55 & 3,44 & 87,5 & 12,5 & 87,5 & 12,5 \\
\hline chcem učit' v MM & 96,55 & 3,44 & 50 & 50 & 87,5 & 12,5 \\
\hline
\end{tabular}

Legenda: ALT - alternatívne pedagogické smery v obsahu štúdia, MMPG - pedagogika Márie Montessoriovej v obsahu štúdia, MM - pedagogika Márie Montessoriovej.

V d’alších otázkach sme sa pýtali: Učili ste sa počas štúdia o alternatívnych prístupoch v edukácii?, Venovali ste sa počas štúdia aj pedagogike Márie Montessoriovej?, Zaujala Vás počas štúdia pedagogika Márie Montessoriovej?, Chceli by ste učit' v montessori MŠ?

Z Tab. 3 je zrejmé, že vyučovanie o alternatívnych pedagogických smeroch, vrátane pedagogiky Márie Montessoriovej prebieha na všetkých úrovniach vzdelávania budúcich učitel'ov materských škôl na východnom Slovensku v Košickom a Prešovskom kraji. Väčšinu respondentiek pedagogika Márie Montessoriovej zaujala, a 96,5\% absolventiek prvého stupňa vysokoškolského štúdia a $87,5 \%$ absolventiek úplného odborného štúdia by chcelo pracovat' $v$ materskej škole montessori (resp. uplatňujúcej prvky pedagogiky Márie Montessoriovej). Absolventky druhého stupňa vysokoškolskej prípravy odpovedali takto: $50 \%$ áno, $50 \%$ nie.

V tab. 4 prezentujeme zameranie štúdia, resp. vyučovania o pedagogike Márie Montessoriovej. Zaujímalo nás či šlo viac o teoretickú, alebo praktickú prípravu. Praktickou prípravou rozumieme informácie o didaktických materiáloch, didaktike (didaktické princípy), či metodike (trojkroková metóda) a priamom nácviku prevedenia práce s didaktickými materiálmi. 
Tab. 4: Pedagogika Márie Montessoriovej - príprava

\begin{tabular}{|c|c|c|c|c|c|c|c|c|c|c|c|c|c|c|c|}
\hline & \multicolumn{13}{|c|}{ teoretická } & \multicolumn{2}{|c|}{ praktická } \\
\hline & \multicolumn{3}{|c|}{1} & \multicolumn{3}{|c|}{2} & \multicolumn{3}{|c|}{3} & \multicolumn{3}{|c|}{4} & \multicolumn{3}{|c|}{5} \\
\hline & Bc. & Mgr. & Úso & Bc. & Mgr. & úso & Bc. & Mgr. & úso & Bc. & Mgr. & Úso & Bc. & Mgr. & úso \\
\hline & \multicolumn{15}{|c|}{$\%$} \\
\hline MP & 27,5 & 12,5 & 37,5 & 27,5 & $\overline{12,5}$ & 0 & 37,9 & 50 & 25 & 0 & 12,5 & 25 & 6,8 & 12,5 & 12,5 \\
\hline
\end{tabular}

Legenda: MP - Montessori príprava

Z Tab. 4 je zrejmé, že príprava, resp. výučba pedagogiky Márie Montessoriovej, na stupňoch vysokoškolského vzdelávania je orientovaná teoreticko-prakticky, čo podla nášho názoru vyplýva z charakteru a špecifík predmetnej pedagogiky. Filozofickopedagogické východiská musia, resp. mali by byt' doplnené praktickými ukážkami materiálu, ukážkami práce detí s materiálom v pripravenom prostredí (aj ked'iba videozáznamom), poprípade exkurziami. Na strednej škole ide o viac teoretické vyučovania, čo by však bolo vhodné a potrebné doplnit' ukážkami materiálu, resp. vyššie spomenutých videozáznamov.

Názor absolventiek, kvalifikovaných učiteliek materských škôl, na pedagogiku Márie Montessoriovej sme zist'ovali otázkou, ktorá ich nabádala pozriet' sa na predmetnú pedagogiku očami diet’at'a: Čím je podla Vás pedagogika Márie Montessoriovej zaujímavá a atraktívna pre diet’a v materskej škole?

Tab. 5: Odpovede respondentiek k definovaniu atraktivity pedagogiky Márie Montessoriovej

\begin{tabular}{|c|c|c|}
\hline Bc. & Mgr. & Úso \\
\hline 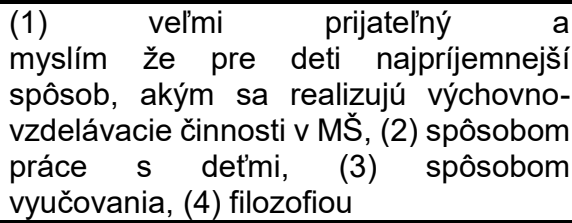 & $\begin{array}{l}\text { (1) je to niečo iné, deti na to } \\
\text { rôzne reagujú }\end{array}$ & \\
\hline $\begin{array}{l}\text { (1) rozvíjame schopnost' samostatne } \\
\text { sa rozhodovat', } \\
\text { samostatnost'ou detí, (2) (3) vykonávat' } \\
\text { samou } \\
\text { rôzne činnosti samo, (4) diet'a sa uči } \\
\text { samostatnosti }\end{array}$ & $\begin{array}{l}\text { (1) diet'a je samostatné v hre a } \\
\text { učení, (2) samostatnost', (3) } \\
\text { samostatnost' a pomáha } \\
\text { budovat' sebadôveru diet'at'a, (4) } \\
\text { diet'a sa učí a nadobúda } \\
\text { skúsenosti vlastnou činnost'ou } \\
\end{array}$ & $\begin{array}{l}\text { (1) vebestačnost', } \\
(2) \text { v samostatnosti } \\
\text { (3) "Pomôž mi, aby som } \\
\text { to dokázal sám" }\end{array}$ \\
\hline \multirow[t]{2}{*}{$\begin{array}{l}\text { (1) prístupom učitel'a, (2) prístupom, (3) } \\
\text { prístupom učitel'a, (4) učitel' mu } \\
\text { dopomáha pri dosahovaní ciel'ov, (5) } \\
\text { spôsob, akým pristupuje k det'om }\end{array}$} & $\begin{array}{l}\text { (1) učitel' je len facilitátorom, (2) } \\
\text { iným prístupom učitel'ky k det'om }\end{array}$ & (1) prístupom k diet'at'u \\
\hline & $\begin{array}{l}\text { (1) zodpovednost', (2) diet'a má } \\
\text { zodpovednost' }\end{array}$ & \\
\hline $\begin{array}{l}\text { (1) rozvoj ich zručností, zároveň podpora } \\
\text { ich prirodzeného vývinu, (2) harmonicky } \\
\text { sa rozvíja ich celková osobnost' a } \\
\text { podobne, (3) možnosti diet'at'u rozvoj cez } \\
\text { sebavýchovu, (4) vyššou aktivizáciou } \\
\text { detí v jednotlivých činnostiach, (5) velaa } \\
\text { vecí si môžu vyskúšat' "na vlastnej koži“ }\end{array}$ & $\begin{array}{l}\text { (1) využíva tvorivé myslenie pri } \\
\text { učení prostredníctvom hry, }\end{array}$ & (1) zážitkové učenie \\
\hline (1) hra, (2) hravá forma & \begin{tabular}{|lcc}
1 (1) podporuje radost' \\
objavovania a hry
\end{tabular} & \\
\hline
\end{tabular}


(1) hračky, (2) pomôckami, (3) originálne a jedinečné edukačné pomôcky, (4) pomôckami,

(1) sloboda deti, (2) diet'a je vo všetkom slobodné, (3) dobrovol'nost'ou vo výbere činnosti diet'at'a, (4) diet'a si samostatne volí svoju aktivitu, (5) slobodne si vybrat' aktivitu/hru a prostredie, (6) slobodnou vol'bou, (7) dôraz na slobodu diet'at'a pri vyučovacom procese, (8) vol'nost'ou

(1) prostredie

\begin{tabular}{|l|l|} 
(1) využíva prírodné materiály & (1) materiál \\
\hline (1) diet'a má možnost' vol'by & $\begin{array}{l}\text { (1) slobodne a nenásilne, } \\
\text { (2) sloboda, (3) že je } \\
\text { nenásilná. diet'a sa vyvíja } \\
\text { vlastným tempom }\end{array}$ \\
\hline $\begin{array}{l}\text { (1) využíva koberčeky, ktoré } \\
\text { slúzia ako pracovné miesto pre } \\
\text { diet'a }\end{array}$ & $\begin{array}{l}\text { (1) dáva priestor rozvíjat' } \\
\text { všestranné, (2) na rozvoj } \\
\text { mysle (pozn. autorov - } \\
\text { myslenie) }\end{array}$ \\
\hline (1) praktickost' & \\
\hline
\end{tabular}

(1)zameraná na deti, na ich potreby, (2) diet'a sa učí to čo potrebuje $v$ živote praktické veci, (3) deti sa učia bežným úkonom a $\mathrm{k}$ pracovným činnostiam potrebným do života, (4) diet’a sa učí od predškolského veku veciam, ktoré bude využívat' na dennej báze, rado napodobňuje bežné činnosti, (5) dovol'ovanie robit' bežné činnosti

Formulácia a obsah odpovedí na túto otvorenú položku bola rôzna (Tab. 5), na úvod spomenieme, že sa objavila aj odpoved" „neviem“ a „nie je atraktívna v ničom“. Zaujímavé však je, že často v odpovediach rezonovali: sloboda, samostatnost', zážitok a zážitkové učenie, iný prístup učitela, a aj učenie sa praktickým a potrebným zručnostiam. Jednu odpoved', ktorá nás zaujala, sme neuviedli do tabul'ky, citujeme: „tým, že si diet’a môže vyskúšat' činnosti, ktoré $v$ bežnej MŠ nemá možnost'." $\mathrm{Na}$ základe odpovedí respondentov sa zamýšl'ame nad tým, prečo absolventky štúdia, kvalifikované učitel'ky materských škôl, si myslia, že súčasná materská škola neakcentuje učenie sa praktickým zručnostiam a návykom, ktoré deti do života potrebujú, nedáva det'om slobodu, neuplatňuje zážitkové učenie a nepodporuje samostatnost'.

Je potrebné sa na to pýtat' a skúmat' prečo? Kde vidíme problém? Ako ho pomenovat'? Je problém (1) $\vee$ kurikule? (2) $\vee$ často aj dnes uplatňovanom frontálnom spôsobe vyučovania? (3) v organizácii denného poriadku? (4) v metodickej a didaktickej príprave učitel'ov?

(1) Aj v súčasne platnom Štátnom vzdelávacom programe pre predprimárne vzdelávanie v materských školách (2016) nachádzame výkonové štandardy smerujúce k aplikácii zážitkových metód. Na druhej strane, nachádzame aj výkonové štandardy, ktoré naplñajú aj ciele a obsah oblasti z pedagogiky Márie Montessoriovej, Cvičenia každodenného života a pri ich plnení, môže byt' využívaná práca s montessori materiálom. Reprezentujeme na vzdelávacej oblasti Zdravie a pohyb, výkonový štandard Ovláda základné sebaobslužné činnosti. Montessori materiál vhodný na plnenie štandardu: Zapínacie rámy (bližšie Slováček \& Miňová, 2017).

(2) Frontálny spôsob vyučovania, frontálna didaktická forma, je dnes nad'alej uplatňovaná aj v našich materských školách (aj v primárnom vzdelávaní). Je jednou z palety možností (frontálna, skupinová, individuálna) organizácie a manažovania výchovno-vzdelávacích činností, konkrétne vzdelávacích aktivít. V materských školách, kde učenie a učenie sa detí má svoje špecifiká definované vývinovou psychológiou, detskou skúsenostou a rozdielnymi záujmami diet'at'a, je vhodnejšie uplatňovat' a využívat' viac individuálne orientované formy (individuálnu a skupinovú). To môže pripravit' prostredie tak, aby diet'a mohlo venovat' svoju pozornost' tomu, čo ho zaujíma, čo ho upúta, ale aj pracovat' (hrat' 
sa) s materiálom (hračkami) intenzívnejšie a podnecovat' zážitkové učenie sa. Aj toto rozhodnutie výberu možností je v kompetencií učitel'ky, učitela.

(3) Otázka organizácie denného poriadku a odpoved’ na ňu, vychádza zo štátneho vzdelávacieho programu. Vzdelávacia aktivita môže byt' realizovaná ako samostatná čast' dňa, ale aj ako integrálna súčast' ostatných foriem denných činnosti, ktoré sú všetky rovnocenné. Zaradenie vzdelávacej aktivity do harmonogramu denných činností ju predurčuje k frontálnemu a skupinovému charakteru. Opät' to závisí od pedagogických zručnosti a majstrovstva učitel'ky, jej situačného rozhodovania a výberu obsahu výchovy a vzdelávania. Od manažmentu materskej školy tiež záleží ako si vedie svoj kolektív v metodicko-didaktickej rovine prípravy a realizácie edukačného procesu $v$ jednotlivých formách denných činností. No i v rámci nich môže byt' naplno podporované zážitkové učenie a učenie sa, sloboda, praktickost' a práca s rozmanitým didaktickým materiálom. (4) Otázka metodickej a didaktickej prípravy učitel'ov pramení z nastavenie študijných plánov v jednotlivých študijných odboroch a programoch. Opät' je namieste spomenút' informáciu k predmetu Súčasné trendy v edukácii (Prešovská univerzita v Prešove - Mgr. - Predškolská pedagogika). Počas semestra je problematike venovaná 1 vyučovacia hodina v podobe prednášky aj seminára (Slováček \& Miňová, 2020). Študenti odboru psychológia na Trnavskej univerzite $v$ Trnave majú študijnom pláne predmet Montessori metóda a jej využitie $\vee$ psychológii $(P V) \vee$ trvaní jedného semestra a $s$ podmienkou absolvovania dvoch predmetov, a študenti $\vee$ odbore Učitel'stvo a pedagogické vedy, program Predškolská a elementárna pedagogika, Predškolská pedagogika a Učitel'stvo pre primárne vzdelávanie nie? (pozri bližšie Slováček \& Miňová, 2020).

Prečo dnes, $v$ dobe osobnostne orientovanej predprimárnej edukácie, ked' všetci píšeme, hovoríme a čítame o humanizácii, potrebách a právach detí, ked' máme širokú vedomost' z oblasti psychológie (vývinovej, pedagogickej), neuropedagogiky a neurodidaktiky, či kognitívnej edukácie, majú absolventky, učitel'ky po štúdiu a povinnej pedagogickej praxi pocit, že je sloboda, samostatnost', prístup k diet'at'u... niečím zaujímavým pre diet'a, čiže neprítomným v tradičnej materskej škole? Poznámka autorov: Odpovede respondentiek sú výstižné a správne k definovaniu pedagogiky Márie Montessoriovej a vo všetkých obsahoch, formách a vzt'ahoch sa zhodujeme a súhlasíme s tým, že sloboda, samostatnost', cvičenia každodenného života a nielen všetky odpovede z tabul'ky (aj ovel'a viac) sú nevyhnutné, potrebné, dôležité a prirodzené pri výchove, vzdelávaní a výcviku našich detí.

\section{Záver}

V príspevku sme predložili deskripciu a analýzu osobnosti učitel'a materskej školy $v$ kontexte pedagogiky Márie Montessoriovej z pohl'adu mozgovo-kompatibilného prostredia (neuropedagogiky a neurodidaktiky), NTC systému učenia detského mozgu a pôsobenia na mozgové hemisféry. Osobnost' montessori učitel'a materskej školy popisuje cez jeho roly podla Miňovej (2014) a Syslovej (2017), kompetencie podla viacerých autorov a cnosti podla Rýdla (2007), ktoré zastáva a disponuje nimi v dnešnej koncepcii výchovy, vzdelávania a výcviku v materskej škole aj s ohl'adom na príslušnost' montessori prístupu k personalistickým teóriám výchovy. Prezentovali sme výsledky s interpretáciu prieskumu realizovaného v roku 2020 medzi absolventkami formálneho vzdelávania predškolskej pedagogiky v Košiciach a Prešove.

Záverom môžeme konštatovat', že najkompetentnejšie sa cítia byt' absolventky druhého stupňa vysokoškolskej prípravy v kompetenciách odborno-predmetových, pedagogickodidakticko-psychologických, komunikatívnych a kompetenciách plánovat' a projektovat' prácu s det'mi. Dobrým signálom aj pozitívnou perspektívou je, že ani absolventky prvého stupňa vysokoškolskej prípravy a pomaturitného štúdia, pocit'ujú dostatočnú prípravu v uvedených kompetenciách. Alternatívne pedagogické smery aj pedagogika Márie Montessoriovej sú obsahom formálnej prípravy budúcich učitel'ov materských škôl, čo je 
taktiež pozitívny predpoklad pre ich implementáciu, aj ked'iba prvkov do výchovnovzdelávacej a výcvikovej praxe materských škôl, samozrejme po rozšírení poznania a spôsobilostí neformálnym a informálnym vzdelávaním. V navrhovanom Pláne obnovy sa kladie dôraz na prepojenie teórie s praxou. Aj $v$ tomto prípade sa nám na fakultách ponúka myšlienka návrhu, napr. výberových predmetov so zameraním na pedagogiku Márie Montessoriovej s nadväzujúcimi predmetmi v jednotlivých ročníkoch, ktoré môžu zabezpečovat' aj odborníci z pedagogickej praxe a potom následná pedagogická prax v týchto materských školách. Ako sme uviedli vyššie je nevyhnutné, ako predpoklad podpory myšlienky demokratizačných, humanizačných a osobnostne orientovaných pluralitných tendencií, podporit' kvantitu, aj kvalitu vysokoškolskej výučby budúcich učitel'ov v oblasti alternatívnych pedagogických smerov, s dôrazom na pedagogiku Márie Montessoriovej, ktorá svojimi výsledkami pozitívne presahuje aj do edukácie detí so špeciálnymi výchovno-vzdelávacími potrebami. Rýdl (2011), ktorý tvrdí: „Zásady a princípy montessoriovskej pedagogiky boli formulované nie teoreticky od zeleného stola na základe naivných idealistických predstáv a prianí autorov, ale postupne na základe dlhoročných pozorovaní správania detí pri rôznych činnostiach. Ide teda o transparentný príklad tzv. evidence-based research, teda o výskumy postavené na empiricky preukázatel'ných dôkazoch, čo je z hl'adiska metodológie pedagogickej vedy plne moderný prístup. Myslím, že žiadna metóda uplatňovaná v súčasnosti v pedagogickej praxi nemá tak jasnú a dlhodobo empiricky overenú vedeckú platnost'." O takto orientovanej príprave budúcich učitel'ov sme publikovali v roku 2020 (Slováček \& Miňová, 2020). Pedagogika Márie Montessoriovej a jej didaktická aplikácia má uplatnenie nielen v prostredí predprimárnej a primárnej edukácie, ale aj na vyšších stupňoch vzdelávania. Na základe odpovedí na otázku Čím je podla Vás pedagogika Márie Montessoriovej zaujímavá a atraktívna pre diet'a v materskej škole? sme nastolili tézy pre d'alšie úvahy a skúmanie dôvodov odpovedí uvedených vyššie.

\section{Literatúra}

Collins, J. W. \& N. P. O'brien (Eds.). (2003). The Greenwood dictionary of education. London: Greenwood publishing group.

Everhardtová, Ch. (2000). Pedagogika Marie Montessoriové v rodině a mateřské škole. In L. Harald (Ed.), Vychováváme a vzdělávame s Marii Montessoriovou (Praxe reformně pedagogické koncepce) (s. 45-64). Pardubice: Univerzita Pardubice.

Genialita Montessori pomůcek aneb jak úspěšne zapojit různé části mozku. (2014). Montessori zpravodaj. Dostupné z: www.montessoricr.cz.

Guziová, K., Podhájecká, M. \& Kimličková, J. (2011). Kompetencie učitel'ky materskej školy ako predpoklad rozvíjania kompetencií detí. In V. Hajdúková (Ed.), Metodika predprimárneho vzdelávania (s. 60-67). Bratislava: Štátny pedagogický ústav. Helus, Z. (1995). Jak dál ve vzdělávaní učitelů. Pedagogika 45(2) 105-109.

Helus, Z. (1995). Jak dál ve vzdělávaní učitelů. Pedagogika. 45(2) 105-109.

Hupková, M. \& Petlák, E. (2007). Sebareflexia a kompetencie v práci učitela. Bratislava: IRIS.

Kasáčová, B. (2004). Učitel'ská profesia v trendoch teórie a praxe. Prešov: Metodicko pedagogické centrum.

Matsumoto, D. (Ed.). (2009). The Cambridge Dictionary of Psychology. Cambridge: Cambridge University Press.

Matulčíková, M. (2007). Reformnopedagogické a alternatívne školy a ich prínos pre reformu školy. Bratislava: AG MUSICA LITURGIA.

Miňová, M. (2012). Kompetencie učitel'ov predprimárneho vzdelávania. In A. Prídavková \& M. Klimovič (Eds.), Komplexnost' a integrita v predprimárnej, primárnej a špeciálnej edukácii (s. 83-89). Prešov: Vydavatel'stvo Prešovskej univerzity. 
Miňová, M. (2014). Diet'a, detstvo a rola učitel'a. In E. Novotná (Ed.), Montessori v priestore formálneho a neformálneho vzdelávania učitelov (s.54-63). Prešov: Prešovská univerzita v Prešove.

Miňová, M. (2018/2019). NTC systém učenia detského mozgu prostredníctvom cvičení. Naša škola. 22(1-2) 10-12.

Miňová, M. (2019). Vysokoškolská príprava budúcich učiteliek materských škôl. Edukácia. Vedecko-odborný časopis. 3(2) 122-133.

Montessori, M. (2001). Objevováni dítěte. Praha: Nakladatelství světových pedagogických směrů.

Petlák, E. (2002/2003). Kompetencie učitel'a. Naša škola. 6(8).

Petlák, E., Valábik, D. \& Zajacová, J. (2009). Vyučovanie - mozog - žiak. Bratislava: IRIS.

Podhájecká, M. (2014). Graduálna a postgraduálna formácia pedagógov v kontexte predškolskej pedagogiky. In A. Prídavková \& M. Klimovič (Eds.), História, súčasnost' a perspektívy vzdelávania na Pedagogickej fakulte Prešovskej univerzity v Prešove (4759). Prešov: Vydavatel'stvo Prešovskej univerzity.

Portik, M. (2002). Reflexie začínajúcich učitel'ov na úroveň praktickej prípravy počas štúdia. In B. Kasáčová (Ed.), Spolupráca univerzity a škôl. Banská Bystrica.

Portik, M. (2014). Kontexty primárnej edukácie na Pedagogickej fakulte PU V Prešove. In A. Prídavková \& M. Klimovič (Eds.), História, súčasnost' a perspektívy vzdelávania na Pedagogickej fakulte Prešovskej univerzity v Prešove (s. 36-46). Prešov: Vydavatel'stvo Prešovskej univerzity.

Průcha, J. \& Kotátková, S. (2013). Předškolní pedagogika. Praha: Portál.

Rajović, R. (2018). NTC Systém učení. Metodická príručka pro práci s NTC metodou. Část 2 - věk 4-8 roků. Jak úspěšne rozvíjet IQ dítěte hrou. Praha: Mensa České republiky.

Rozhodnutie číslo: 2016-8672/15327:4-100B, 2016, In: www.statpedu.sk.

Rýdl, K. (2007). Metoda Montessori pro naše dítě: Inspirace pro rodiče a další zájemce. Pardubice: FF Univerzity Pardubice.

Rýdl, K. (2011). Předslov. In: M. Montessori. Od dětství k dospíváni. Praha: Triton.

Slováček, M. \& Miňová, M. (2017). Pedagogika Márie Montessoriovej - terminologické minimum alebo Montessori pedagogika pre každého. Prešov: Rokus.

Slováček, M. \& Miňová, M. (2019). Pedagogika Márie Montessoriovej z pohladu teórie a praxe. Prešov: Rokus.

Slováček, M. \& Miňová, M. (2020). Pedagogika Márie Montessoriovej: vzdelávanie a kompetencie učitelov materských škôl. Prešov: Prešovská univerzita v Prešove.

Slováček, M. (2015). Vzdelávanie učitel'ov materských škôl a pedagogika Márie Montessoriovej. In M. Podhájecká \& M. Miňová (Eds.), Teória a prax trvalo udržatel'ného rozvoja v materských školách (s. 124-135). $\quad$ Prešov: Vydavatel'stvo PU v Prešove.

Slováček, M., \& Miňová, M. (2015). „Zabudnutá?" - Pedagogika Marie Montessori. In J. Žolnová \& T. Dubayová (Eds.), Študent na ceste k praxi IV (s. 145-152). Prešov:

Prešovská univerzita v Prešove, Pedagogická fakulta.

Syslová, Z. (2017). Učitel v předškolním vzdělávání a jeho príprava na profesi. Brno: Masarykova univerzita.

Švec, V. (1998). Pedagogické vědomosti a dovednosti - jádro pedagogických kompetencí. Pedagogická orientace. 8(4) 19-32.

Kolektív autorov. (2016). Štátny vzdelávací program pre predprimárne vzdelávanie $v$ materských školách. Štátny pedagogický ústav

Turek, I. (2003). Klúčové kompetencie. Prešov: Metodicko - pedagogické centrum.

Vyhláška č. 1/2020 Z. z. o kvalifikačných predpokladoch pedagogických zamestnancov a odborných zamestnancov 
www.erudio-montessori.cz

www.monteplus.sk

www.time.com

Zelina, M. (2000). Alternatívne školstvo. Bratislava: IRIS

Zelina, M. (2018). Pedagogika nádeje. Studia scientificata facultatis paedagogicae 17(1) 13-18.

Zelinková, O. (1997). Pomoz mi, abych to dokázal. Praha: Portál.

\section{Adresy autorov}

\section{PhDr. PaedDr. Matej Slováček}

Základná škola, Ruskov

Ruskov 32, 04419 Ruskov

\section{PaedDr. Monika Miňová, PhD.}

Katedra predškolskej a elementárnej pedagogiky a psychológie, Pedagogická fakulta, PU v Prešove

UI. 17. novembra č. 15,08001 Prešov

monika.minova@unipo.sk 


\title{
UČITEL'OVA OSOBNÁ POTREBA ŠTRUKTÚRY A POSTOJE ŽIAKOV K UČITEL'OVI A NEMECKÉMU JAZYKU
}

\section{TEACHER'S PERSONAL NEED FOR STRUCTURE AND ATTITUDES OF PUPILS TO THE TEACHER AND GERMAN LANGUAGE}

\author{
Svetlana Stančeková \\ Katedra germanistiky, Filozofická fakulta, UKF v Nitre
}

\begin{abstract}
:
The paper deals with the topic of the personal need for structure as a personality trait of a teacher. The personal need for structure is the individual's ability to structure in a world full of information and to reduce chaos. As a result, they can exist in difficult environments and in indefinite situations. In our research, we find out what level of personal need for structure teachers have and whether it is related to pupils' attitudes to learning German. Attitudes are among the many factors that influence the second language acquisition, in our case we focus on the German language. We found that for pupils, the teacher is an important determinant of teaching and also that teachers in research showed a high level of personal need for structure. It seems that a teacher who prefers structure in his life and thus in class, is positively perceived and evaluated by students. The teacher perceived in this way is able to influence the attitudes of students and thus, at least in part, their school success.
\end{abstract}

Key words:

personal need for structure, attitude, teacher

\section{Teoretické východiská}

Jednotlivec žije v prostredí, ktoré je bohaté na informácie. Aby sa v nich jednotlivec nejakým spôsobom zorientoval a nestratil vich množstve, vypracováva si stratégie a postupy, ktoré mu pomáhajú tieto informácie triedit'. Týmto spôsobom dochádza k vytváraniu štruktúr alebo kategórií, pomocou ktorých jednotlivci vedia vytriedit' a spracovat' informácie, ktoré sa k nim dostanú. Dokážu určit', ktoré informácie sú pre nich relevantné, a ktoré sú menej podstatné. Každý jednotlivec má svoju osobnú potrebu štruktúry.

Pojem osobnej potreby štruktúry (Personal Need for Strucutre - PNS), ako ju charakterizuje Neuberg a Newsom (1993), vyjadruje charakteristické fungovanie jednotlivca v neurčitých situáciách. Táto štruktúra pomáha zredukovat' komplexnost' prostredia a dosiahnut' určitú mieru istoty filtráciou neadekvátnych informácií. Osoby s vysokou mierou potreby štruktúry sa t’ažšie vyrovnávajú s nejednoznačnost'ou, sú menej ochotní zmenit' postoje, preferujú stereotypné správanie a v neurčitých situáciách sa môžu cítit' nekomfortne a neisto. Osoby s nízkou mierou potreby štruktúry sa vyznačujú určitou pružnost'ou vo vnímaní a spracovávaní informácií, radi prekračujú hranice stereotypov a skúšajú nové algoritmy v riešení úloh (Stranovská, 2011). 
Konštruktu osobnej potreby štruktúry sa venovali aj Thompson a kol. (2001), ktorí tvrdia, že osobná potreba štruktúry sa objavuje vtedy, ked' indivíduum pocit'uje túžbu po poriadku, pravidlách a konzistencii. Aj Moskowitz (2005) predpokladá, že jednotlivci potrebujú štruktúru na dosiahnutie kategorizácie, ktorá mu zjednoduší jeho okolie tak, aby organizmus dokázal efektívne fungovat'. Blais, Thompson a Baranski (2003) predpokladajú, že táto potreba štruktúry predstavuje adaptívnu stratégiu, ktorá ul'ahčuje kontrolu a predvídatel'nost' v našom komplikovanom a komplexnom svete.

$\checkmark$ rámci osobnej potreby štruktúry boli zistené dva prvky, ktoré potrebu štruktúry ovplyvňujú. Jedná sa o želanie štruktúry (Desire for Structure - DFS) a reakcia na chýbanie štruktúry (Reaction to the Lack of Structure - RLS). DFS znamená rozsah, aký by mala mat' štruktúra, ktorú chce jednotlivec dosiahnut' vo svojom živote. Tí jednotlivci, ktorí mávajú vysoké želanie štruktúry, uprednostňujú aj vo svojom vlastnom živote jeho jasnú organizáciu, ich veci majú stále miesto a udržiavajú štruktúrovaný spôsob života. RLS predstavuje odpoved' na neurčitú, nepredvídatel'nú situáciu. Vyššie skóre v chýbaní štruktúry dosahujú práve jednotlivci, ktorí nemajú radi neisté úlohy a situácie alebo krátkodobé zmeny $v$ ich plánoch.

$\checkmark$ rámci skúmania potreby štruktúry bolo realizovaných viacero zaujímavých výskumov. Sarmány-Schuller (2000) uskutočnil test PNS v oblasti edukácie, kde respondenti boli uchádzači o vysokoškolské štúdium pedagogiky. Výskum ukázal, že jednotlivci s vyššou potrebou štruktúry sa zvyknú učit' metodicky, štruktúrovane, zatial' čo intuitívne založení jednotlivci preukázali aj nižšiu potrebu osobnej štruktúry.

Švecová a Pavlovičová (2016) skúmali vplyv PNS žiakov pri riešení slovných úloh z matematiky o zlomkoch a zistili, že čím bolo vyššie dosiahnuté skóre v PNS, tým menej bol žiak úspešný $v$ riešení matematickej úlohy. Respondentom so silnejšou PNS tiež robia problém geometrické zadania (Wojtowicz \& Wojtowicz, 2015). Niekedy sa predpokladá súvislost' PNS s kreativitou, avšak Johnsonová (2019) vo svojom výskume zistila, že osobná potreba štruktúry všeobecne nemusí mat' vplyv na tvorivý potenciál človeka. Taktiež osoby s vysokou potrebou osobnej štruktúry potrebujú pocit kontroly vo svojom prostredí (Noordewier, Rutjens, 2021).

Zvykne sa predpokladat', že jednotlivec s vysokou potrebou štruktúry patrí skôr k l'ud'om konzervatívnym až úzkoprsým. Majú sklony $\mathrm{k}$ stereotypom a ignorovaniu nových a neočakávaných informácií. Avšak výskum Kemmelmaiera (2015) ukázal, že vysoké želanie štruktúry (DFS) nemusí nevyhnutne znamenat', že daný jednotlivec nemá otvorenú mysel'.

Aj v našich výskumoch (Stančeková, 2017; Stančeková \& Stranovská, 2018) sa javí, že učitel' je dominantným faktorom pri osvojovaní si cudzieho jazyka. Žiaci vykazovali pomerne pozitívne postoje k nemeckému jazyku a jeho osvojovaniu si, ukazujú vôl'u učit' sa, avšak potrebujú k tomu okrem iného aj pomoc učitel'a. Postoje ovplyvňujú správanie a konanie jednotlivca a teda aj žiakov pri výučbe cudzieho jazyka.

Postoj je jedným z pojmov sociálnej psychológie, ktorý vyjadruje sklon, pripravenost' k reakcii na objekt postoja. Týmto objektom môžu byt' predmety, osoby, situácie. Myers (2016, s.110) hovorí, že postoj je „priaznivá alebo nepriaznivá hodnotiaca reakcia vo vzt'ahu k niečomu či niekomu (často má korene v osobných presvedčeniach a prejavuje sa vo forme pocitov a zamýšl'aného správania)“. Postoje teda súvisia s tým, čo jednotlivec robí, ako sa správa.

Postoje disponujú tromi zložkami (Werth \& Mayer, 2008):

1. afektívnou - jedná sa o city a emócie, ktoré sa jednotlivcovi spájajú s objektom postoja, jedná sa napr. o sympatie a antipatie,

2. konatívnou - sú založené na správaní a znamenajú správanie alebo reakciu jednotlivca voči objektu postoja, toto konanie sa ale nemusí navonok 
prejavit', niekedy ho jednotlivec prejaví explicitne, niekedy ostane v rovine intencie,

3. kognitívnou - tieto zahŕňajú názory, myšlienky, presvedčenia, ktoré si jednotlivec asociuje s objektom postoja.

Všetky tieto tri zložky sa podiel'ajú na vytváraní celkového postoja (Gollwitzer \& Schmidt, 2006; Haddock \& Maio, 2007).

Garrett (2010, s. 23) uviedol súvislost' všetkých troch zložiek postoja s učením sa cudzieho jazyka v nasledujúcom príklade:

„Pokial' ide o jazyk, potom, ak by sme uvažovali o postoji študentky k španielčine ako cudziemu jazyku, mohli by sme hovorit' o kognitívnej zložke (je presvedčená, že štúdium španielčiny jej poskytne hlbšie pochopenie španielskej kultúry), afektívnej zložke (je nadšená schopnost'ou čítat' literatúru napísanú v španielčine) a zložke správania (šetrí peniaze za zápis na kurz španielčiny)“ (Garrett 2010, s. 23).

Aj to, ako sa jednotlivec správa na verejnosti, určujú okrem iného aj postoje. Z týchto dôvodov je potrebné zaoberat' sa postojmi v škole, či na vyučovaní, postoje totiž predstavujú jeden z dôležitých determinantov školskej úspešnosti.

Výskumy ukazujú, že väčšina žiakov pozitívne reaguje na štruktúru v škole (Meador, 2018). Učitel', ktorý je dominantným elementom na vyučovaní (Kopčanová, 2004; Uhláriková, 2018; Wisniewski, 2013), sa na nej podiel'a. Preto sme chceli zistit', aké postoje majú žiaci ohl'adom osvojovania si nemeckého jazyka a akú potrebu štruktúry vykazovali ich učitel'a.

\section{Praktická čast'}

\section{Výskumný ciel'}

Tak postoje ako aj osobnostné faktory, súčast'ou ktorých je aj osobná potreba štruktúry, predstavujú neoddelitel'nú súčast' osvojovania si cudzieho jazyka. Patria k faktorom, ktoré tento proces ovplyvňujú. Preto sme chceli zistit', v akej miere sú u vybraných respondentov zastúpené. Z toho sme stanovili výskumné otázky:

Aké sú postoje žiaka k učitel'ovi a nemeckému jazyku?

Aká je osobná potreba štruktúry ich učitel'a?

\section{Výskumná vzorka}

Výskumu sa zúčastnilo celkom 180 respondentov, z toho 8 pedagógov a 172 žiakov. Respondentov - žiakov sme vyberali na základe toho, či sa v škole učia nemecký jazyk. Vek respondentov - žiakov predstavoval od 12 do 19 rokov. Dotazníky vyplnilo 84 chlapcov a 88 dievčat. Základnú školu navštevovalo 65 (7.-9. ročník), strednú školu 107 žiakov (1.-4. ročník), ich priemerný vek bol 16 rokov. Vyučujúci boli učitel'mi nemeckého jazyka. Jeden z nich bol muž, ostatné boli ženy. Všetci boli učitelia s praxou nad 5 rokov, ich priemerný vek bol 41 rokov. Žiaci vyplnili test sémantického diferenciálu a učitelia dotazník PNS.

\section{Metódy výskumu}

Dotazník potreby štruktúry (PNS), ktorý vypĺňali učitelia, zist'uje úroveň potreby štruktúry v rôznych životných situáciách (Thompson, Naccarato \& Parker, 1989, in Neuberg \& Newsom, 1993). Osobná potreba štruktúry predpokladá, že existuje súvislost', medzi tým byt' schopný redukovat' neurčitost' situácie a schopnost'ou vediet' riešit' nové situácie. Osobná potreba štruktúry je spojená s kognitívnym hodnotením a riešením problému. Obsahuje emočnú skúsenost' a súvisí s intenzívnejšou afektívnou odpoved’ou.

Test do slovenčiny preložil Sarmány-Schuller (1993, in Sollár, 2005) a predstavuje nástroj na meranie osobnej potreby štruktúry. Obsahuje dve subškály, DFS - želanie štruktúry a RFS - reakcia na chýbanie štruktúry, ktoré sú zahrnuté v položkách testu. 
Neuberg a Newsom (1993) zistili pozitívny vzt’ah medzi celkovým skóre dotazníka PNS a svedomitost'ou a neurotizmom, pričom neurotizmus súvisí s reakciou na chýbanie štruktúry a svedomitost' zase súvisí so želaním štruktúry.

Ide o štandardizovaný dotazník, ktorý obsahuje dvanást' položiek, ktoré sú orientované na štruktúrovanost' prostredia. $V$ ňom majú respondenti posúdit', nakol'ko s nimi súhlasia, podla svojej mienky, skúseností a postojov. Odhad Cronbachovej alfy bol 0,71. Respondenti majú na šest'stupňovej Likertovej škále označit', do akej miery súhlasia s výrokmi, napr. či je rád spontánny, či má rád usporiadaný spôsob života alebo či neznáša, ked'sa na poslednú chvíl'u menia plány. Skóre z jednotlivých položiek, ktoré respondent označil, sa spočíta. Respondent môže dosiahnut' počet bodov od 12 do 72 . Ked' respondent dosiahne vyššie skóre, indikuje to jeho vyššiu osobnú potrebu štruktúry. Osoby s vysokou potrebou štruktúry sa rozhodujú skôr pomocou úsudkov založených na kategóriách, sú totiž viac motivovaní nájst' v danom prostredí štruktúru.

Sémantický diferenciál je výskumná metóda, vyvinutá Ch. E. Osgoodom (1957) v pät'desiatych rokoch dvadsiateho storočia. Sémantický diferenciál zist'uje, ako jednotlivci vnímajú pojmy. Každý pojem obsahuje okrem denotatívneho aj konotatívny význam. Denotatívny význam predstavuje očividný, všeobecne platný význam daného pojmu. Naproti tomu konotatívny označuje subjektívny, skrytý význam, je to to, čo si jednotlivec pod týmto pojmom predstaví, asociuje. Táto metóda je štandardizovaná, avšak môže byt' modifikovaná.

Náš dotazník sme adaptovali na výskum pojmov nemecký jazyk a učitel' nemeckého jazyka. Ku každému pojmu prislúcha osemstupňová škála 1-8, na konci ktorej sa nachádzajú bipolárne prídavné mená. Na tejto stupnici predstavovalo číslo 1 najviac pozitívnu asociáciu a číslo 8 najviac negatívnu asociáciu. K pojmu nemecký jazyk mali respondenti k dispozícii nasledovné prívlastky: zaujímavý - nezaujímavý, jednoduchý komplikovaný, dobre znejúci - zle znejúci, atraktívny - neatraktívny, príjemný nepríjemný. K pojmu učitel' nemeckého jazyka mali respondenti k dispozícii nasledovné prívlastky: priatel'ský - odmeraný, aktívny - pasívny, istý - neistý, tvorivý - stereotypný, liberálny - autoritatívny, nenáročný - náročný, komunikatívny - málo komunikatívny. Žiaci vyznačili svoje postoje $\mathrm{k}$ danému pojmu pomocou daných prívlastkov na škále a táto ukázala intenzitu postojov respondenta $\mathrm{k}$ nim. Vypočítali sa priemerné hodnoty jednotlivých vlastností u každého pojmu a umiestnili sa do sémantického priestoru.

\section{Výsledky}

Na rozbor údajov sme použili deskriptívnu štatistiku. Výsledky z dotazníka Sémantického diferenciálu sú štandardne zobrazené v sémantickom priestore $v$ dimenziách hodnotenia a sily, také isté zobrazenie sme zvolili aj my. Ide o dve dimenzie, dimenziu sily, ktorá znamená silu, moc - či pôsobí daný pojem silne, dominantne alebo naopak slabo, submisívne a dimenziu hodnotenia, ktorá opisuje aký dojem daný pojem vyvoláva dobrý, príjemný alebo naopak zlý, nepríjemný. Priestor na stupnici 1 až 4 je hodnotený pozitívne ( $v$ dimenzii sily dominantne, v dimenzii hodnotenia dobre), na stupnici 4,1 až 8 naopak negatívne ( $v$ dimenzii sily submisívne, v dimenzii hodnotenia zle). 


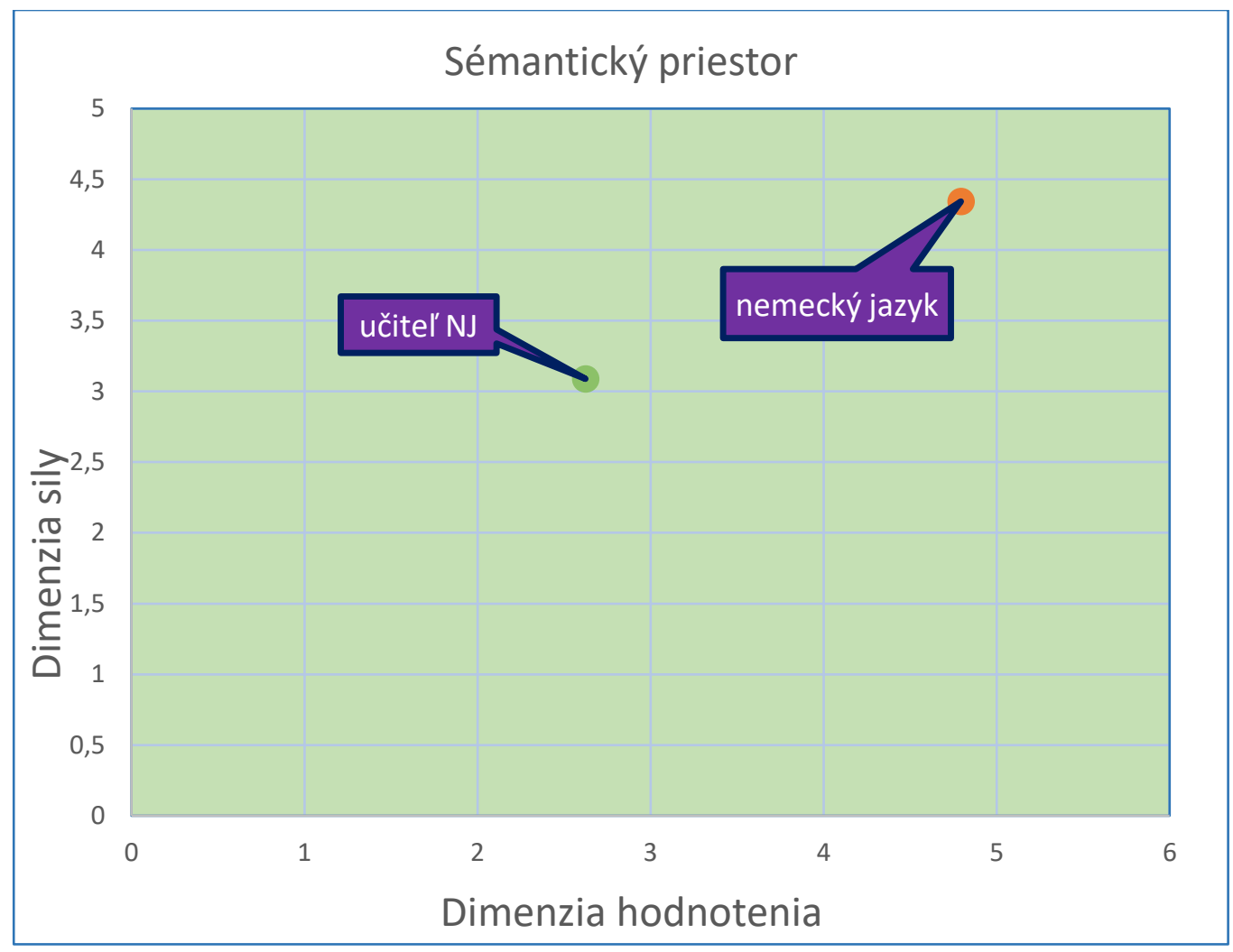

Obr. 1: Sémantický priestor znázorňujúci postoje respondentov k učitel'ovi nemeckého jazyka a nemeckému jazyku

Obr. 1 znázorňuje, ako respondenti vnímajú pojmy nemecký jazyk a učitel' nemeckého jazyka. V popredí stojí učitel' nemeckého jazyka, ktorý je vnímaný skôr dobre, s hodnotou 2,62 v dimenzii hodnotenia a s hodnotou 3.09 v dimenzii sily. Žiaci ho opísali ako priatel'ského, aktívneho a komunikatívneho (dimenzia hodnotenia), tiež ako liebrálneho, sebaistého a dobre pripraveného (dimenzia sily). Je vnímaný ako dobrý a silný. $\checkmark$ sémantickom priestore sa predovšetkým $v$ dimenzii hodnotenia nachádza $v$ pozitívnej oblasti, čo znamená kladné postoje, resp. silné väzby respondentov k nemu. Pri pojme nemecký jazyk vykazujú respondenti tendenciu $\mathrm{k}$ negatívnym postojom, čomu nasvedčujú hodnoty 4,8 v dimenzii hodnotenia a 4,34 v dimenzii sily. Nemecký jazyk bol označený ako nezaujímavý a nepríjemný (dimenzia hodnotenia) a tiež ako zložitý a zle znejúci (dimenzia sily) a je vnímaný skôr zle a menej dominatne.

Okrem postojov respondentov k učitel'ovi a nemeckému jazyku sme skúmali osobnú potrebu štruktúry učitel'a. Respondenti vyplnili dotazík PNS, na základe ktorého sme im vypočítali skóre PNS.

Tab. 1 Osobná potreba štruktúry učitel'ov

\begin{tabular}{|l|l|l|}
\hline Nízka PNS & Stredná PNS & Vysoká PNS \\
\hline 0 & 0 & 8 \\
\hline
\end{tabular}

Legenda: PNS - osobná potreba štruktúry 
V tab. 1 možno vidiet' celkové výsledky z dotazníka PNS. Respondenti sa podla dosiahnutého skóre rozdelili do troch skupín: s nízkou PNS od 0 do 31 , so strednou PNS od 32 do 41 a s vysokou PNS od 42 do 72 bodov. Všetci učitelia, ktorí sa zúčastnili výskumu, vykazujú vysokú osobnú potrebu štruktúry. Javí sa, že žiaci síce nemajú vel'mi pozitívne postoje k osvojovaniu si nemeckého jazyka, avšak učitel'a s vysokou mierou PNS vnímajú pozitívne.

Tab. 2 Želanie štruktúry učitel'ov

\begin{tabular}{|l|l|l|}
\hline Nízke DFS & Stredné DFS & Vysoké DFS \\
\hline 0 & 7 & 1 \\
\hline
\end{tabular}

Legenda: DFS - želanie štruktúry

Vo faktore DFS dosiahli učitelia stredné a vysoké skóre. Strednú úroveň želania štruktúry prejavilo 7 učitel'ov a vysokú 1 učitel'.

Tab. 3 Reakcia učitel'ov na chýbanie štruktúry

\begin{tabular}{|l|l|l|}
\hline Nízke RLS & Stredné RLS & Vysoké RLS \\
\hline 0 & 3 & 5 \\
\hline
\end{tabular}

Legenda: RLS - reakcia na chýbanie štruktúry

Vo faktore RLS prejavili 3 učitelia strednú a 5 učitelia vysokú úroveň reakcie na chýbanie štruktúry.

\section{Diskusia}

Z viacerých výskumov vyplýva, že učitel' a jeho osobnost' sú v súčasnej škole kl'účovým a nenahraditel'ným prvkom v procese vyučovania (Kopčanová, 2004; Uhláriková, 2018; Wisniewski, 2013). Taktiež v našom výskume bol učitel' ten, ktorého žiaci vnímali dobre, silno a dominantne bez ohl'adu na školu, z ktorej pochádzali. Voči učitel'ovi prechovávajú kladné postoje aj pozitívne emócie. Svojho učitel'a pokladajú za dobrého a príjemného a zároveň za silného a dominantného.

Žiaci prejavili k učitel'ovi pozitívne väzby. Javí sa, že učitel' zohráva dominantnú úlohu $\checkmark$ procese osvojovania si nemeckého jazyka. Práve učitel' by sa mal preto čo najviac koncentrovat' na motiváciu pri jednotlivých zložkách učenia sa. V tomto smere súhlasíme s Dörnyeim (2014) a Riemerovou (2010), ktorí sa usilujú o integráciu predchádzajúcich motivačných teórií (intrapsychická dimenzia motivácie, ktorá mala určit' kvalitu motivácie) a o komplexnost' motivácie. Tieto modely sú väčšinou multidimenzionálne a pozorujú spolupôsobenie medzi jednotlivými internými a externými dimenziami motivácie.

Okrem toho sme sa zamerali na osobnú potrebu štruktúry vyučujúcich ako osobnostnú črtu. Všetkých osem učitel'ov cudzieho jazyka z nášho výskumu vykázalo vysokú úroveň osobnej potreby štruktúry. Toto môže byt' spôsobené malou vzorkou respondentov spomedzi vyučujúcich alebo je to možno dané charakteristikou učitel'ského povolania, ktoré si vyberajú jednotlivci práve s vysokou potrebou štruktúry. Učitel', ktorý vedie štruktúrovanú hodinu, je prijímaný s pozitívnymi emóciami (Klassen \& Perry, 2012), čo sa potvrdilo aj v našom výskume. Žiaci postavili svojich učitel'ov nemeckého jazyka do popredia a prejavili im ako kladné emócie, tak aj postoje, napriek tomu, že k samotnému nemeckému jazyku, resp. k osvojovaniu si nemeckého jazyka až také dobré emócie nevnímajú, ani k nim nemajú pozitívne postoje.

U väčšiny učitel'ov v našom výskume sa prejavila i vyššia úroveň reakcie na chýbanie štruktúry, čo znamená, že chýbanie kategorizácie a nejasnost', neurčitost' v nich vyvoláva 
negatívnu psychickú reakciu, ktorej sa snažia vyhnút' práve dôkladným plánovaním svojej vyučovacej činnosti. Väčšina žiakov pozitívne reaguje na štruktúru v škole a naopak pri chýbaní štruktúry dochádza k negatívnym javom ako pokles koncentrácie, nerešpektovanie učitel'a, nevhodné správanie (Meador, 2018). Štruktúra v školskom prostredí predstavuje pre nich istotu, bezpečie, v ktorom sa môžu sústredit' na učenie. Konštatujeme, že učitel' je dominantným prvkom na vyučovaní nielen pri učení sa nemeckého jazyka, čo je potrebné využívat' ako pri motivácii žiakov, tak aj v procese formovania žiackych postojov k danému predmetu, čo môže d'alej viest' práve k vyššej motivácii $\mathrm{k}$ učeniu sa.

Všetci učitelia mali vysokú potrebu štruktúry. U učitel'a s vyššou úrovňou potreby štruktúry je pravdepodobné, ked'že on sám preferuje štruktúru vo svojom živote, že i hodiny bude viest' štruktúrované a dôsledne naplánované. Takéhoto učitela žiaci v našom výskume vnímajú pozitívne. Avšak nevieme vyhodnotit', ako by bol z pohl'adu žiakov vnímaný učitel' s prostrednou alebo nízkou osobnou potrebou štruktúry.

\section{Záver}

Problematika osobnej potreby štruktúry je $v$ dnešnej dobe pomerne široko sledovaná, skúmajú sa otázky spracovávania informácií, schpnost' tvorenia štruktúr, tolerancie na neurčitost', schopnosti kategorizácie a štrukturácie a preto je táto téma stále vysoko aktuálna, nielen v edukačnej oblasti všeobecne, či pri učení sa cudzích jazykov.

Výsledky ukázali, že učitel'ova osobná potreba štruktúry je dôležitým prvkom pravdepodobne nielen pri učení sa cudzieho jazyka. Učitel' by mal taktiež rešpektovat' postoje svojich žiakov, ale zároveň s nimi vediet' pracovat'. Častokrát sú postoje žiakov, predovšetkým ohl'adom nemeckého jazyka, postavené na predsudkoch a stereotypoch, ktoré si doniesli zo svojho sociálneho prostredia. Učitel' by mal ovládat' techniky, ktoré pomôžu postoje žiaka zmenit' $\mathrm{k}$ lepšiemu a tým pomôct' žiakovi aj v motivácii $\mathrm{k}$ učeniu sa nemeckého jazyka.

Výskum má svoje limity predovšetkým v počte zúčastnených učitel'ov, preto sa pre d'alšie skúmanie odporúča zvýšit' výskumnú vzorku vzhl'adom na to, že všetci učitelia vykázali vysokú úroveň osobnej potreby štruktúry. Bolo by potrebné overit' na väčšej vzorke učitel'ov, či si toto povolanie naozaj vyberajú jednotlivci predovšetkým s takýmto osobnostným nastavením. Okrem toho vo výskumnej vzorke prevažujú respondenti z Bratislavy, bolo by prospešné doplnit' respondentov z iných škôl a iných lokalít.

Ďalšia cesta výskumu sa javí v didaktickej kompetencii učitel'a v oblasti jeho pôsobenia na žiacke postoje, ako aj skúmanie osobnej potreby štruktúry žiakov a v súvislosti s osvojovaním si cudzieho jazyka.

\section{Pod'akovanie}

Tento príspevok je podporovaný Agentúrou na podporu výskumu a vývoja na základe zmluvy č. APVV-17-0071 a VEGA 1/0062/19.

\section{Literatúra}

Blais, A., Thompson, M. \& Baranski, J. (2003). The effects of individual differences in cognitive styles on decision-making accuracy and latency. Defence Research and Development Canada.

Dörnyei, Z. (2014). Motivation in second language learning. In M. Celce-Murcia, D. M. Brinton \& M. A. Snow (Eds.), Teaching English as a second or foreign language, 4th ed. (s. 518-531). Boston, MA: National Geographic Learning/Cengage Learning.

Garrett, P. (2010). Attitudes to Language. Cambridge: University Press.

Gollwitzer, M. \& Schmidt, M. (2006). Sozialpsychologie. Workbook. Weinheim: Beltz. Haddock, G. \& Maio, G. R. (2007). Einstellungen: Inhalt, Struktur und Funktionen. In Jonas, Stroebe, Hewstone (Eds.), Sozialpsychologie, (s. 187-223). Springer. 
Johnson, E, (2019). Is Structured Creativity an Oxymoron? The Effects of Moderate Task Structure on Virtual and Face to Face TeamCreative Output. Culminating Projects in Psychology, 13.

Kemmelmeier, M. (2015). The closed-mindedness that wasn't: need for structure and expectancy-inconsistent information In Frontiers in Psychology, vol. 6. Dostupné na https://www.ncbi.nlm.nih.gov/pmc/articles/PMC4488610/ [18.4.2020]

Klassen, R. M., Perry, N. E. \& Frenzel, A. C. (2012). Teachers' relatedness with students: An underemphasized component of teachers' basic psychological needs. Journal of Educational Psychology, 104(1), 150-165.

Kopčanová, D. (2005). Rodové odlišnosti a d’alšie faktory ovplyvňujúce status súčasného učitel'a. In Heller, Daniel; Procházková, Jana; Sobotková, Irena (eds.), Psychologické dny 2004: Svět žena svět mužů : polarita a vzájemné obohacování : sborník př́spěvků z konference Psychologické dny (s. 1-6). Universita Palackého v Olomouci.

Meador, D. (2018). Basic Strategies for Providing Structure in the Classroom. ThoughtCo, Oct. 22, 2018, dostupné na Thoughtco.com/strategies-for-structure-in-theclassroom-4169394 [22.5.2020].

Moskowitz, G. (2005). Social Cognition: Understanding Self and Others. New York: The Guilford Press.

Myers, D.G. (2016). Sociální psychologie, Brno: Edika.

Neuberg, S.L. \& Newsom, J. (1993). Personal Need for Structure. Individual differences in the desire for simple structure. Journal of Personality and Social Psychology, 65 (1), 113-131.

Noordewier, M. K. \& Rutjens, B. T. (2021). Personal need for structure shapes the perceived impact of reduced personal control. Personality and Individual Differences, 170, https://doi.org/10.1016/j.paid.2020.110478.

Osgood, CH. E., Suci, G. J. \& Tannenbaum, P. H. (1957). The Measurement of Meaning. Urbana: University of Illinois Press.

Riemer, C. (2010). Nativistische Ansätze. In Krumm, H. J. et al. (eds.) Deutsch als Fremdund Zweitsprache. Ein internationales Handbuch. Band 1 (s. 799 - 806). Berlin, New York: de Gruyter.

Sarmány-Schuller, I. (2000). Schopnost' vytvárania štruktúry a kategorizácia. In M. Blatný, M. Svoboda, I. Ruisel, J. Výrost (Eds.), Zborník príspevkov z medzinárodnej konferencie „Sociálne procesy a osobnost' (s. 185-190). Psychologický ústav FF MU a Psychologický ústav AV ČR, Brno.

Sollár, T. (2005). Potreba kognitívnej štruktúry $v$ kontexte osobnostných a interpersonálnych premenných. Bratislava: Ústav experimentálnej psychológie SAV.

Stančeková, S. (2017). Endogene Faktoren im Fremdsprachenerwerb. Motus in verbo, 6(1), 39-52.

Stančeková, S. \& Stranovská, E. (2018). Wie attribuieren die Schüler die Ursachen des Misserfolgs. Brünner Hefte zu Deutsch als Fremdsprache, 11(1), 67-77.

Stranovská, E. (2011). Psycholingvistika: Determinanty osvojovania si a učenia sa cudzieho jazyka a kultúry. Brno: MSD.

Švecová, V. \& Pavlovičová, G. (2016). Screening the Personal Need for the Structure and solving word problems with fractions. SpringerPlus. 5(1). 10.1186/s40064-016-22853.

Thompson, M. M. et al. (2001). The Personal Need for Structure (PNS) and Personal Fear of Invalidity (PFI) scales: Historical perspectives, present applications and future directions. In G. Moskowitz (Ed.), Cognitive social psychology: The Princeton symposium on the legacy and future of social cognition (s. 19-39). Mahwah, NJ: Erlbaum.

Uhláriková, J. (2018). Osobnost' učitel'a a motivácia žiakov učit' sa cudzí jazyk. Školský psychológ/Školní psycholog,19(1), 52 - 60. 
Werth, L. \& Mayer, J. (2008). Sozialpsychologie. Berlin: Spektrum.

Wisniewski, B. (2013). Psychologie für die Lehrerbildung. Wien: utb.

Wojtowicz, A. \& Wojtowicz, B. (2015). The personal need for structure as a factor affecting the understanding and projecting of complex spacial structures. Technical transactions architecture, 11-A, 63-72.

\section{Adresa autora}

\section{Mgr. Ing. Svetlana Stančeková, PhD.}

Katedra germanistiky, Filozofická fakulta, UKF v Nitre

Štefánikova 67, 94974 Nitra

stancekova@centrum.sk 


\title{
DIAGNOSTICKÉ KOMPETENCIE ŠTUDENTOV UČITELSSTVA ROZVÍJANÉ METÓDOU MIKROVYUČOVANIA
}

\section{DIAGNOSTIC COMPETENCES OF TEACHING STUDENTS DEVELOPED BY THE MICROTEACHING METHOD}

\author{
Volodymyr Starosta \\ Katedra pedagogiky, Filozofická fakulta, UPJŠ v Košiciach \\ Renáta Orosová \\ Katedra pedagogiky, Filozofická fakulta, UPJŠ v Košiciach
}

\begin{abstract}
:
Preparing professionally high-quality, skilled teachers for the needs of education in today's society is a challenge especially for teachers. The development of the professional competences of future teachers should be the focus of attention. One of the available methods is a simulation method - micro-teaching, in which the student teacher practices the activities related to the educational process and thinks about his activities. Micro-teaching not only improves the student's ability to plan the teaching process, reduce the level of stress and workload of the student in simulated teaching, but also significantly contributes to the professional development of the teacher as a diagnostician and reflexive practitioner. The authors of the paper present the results of research aimed at determining the degree of satisfaction of teacher students with their level of professional competences, specifically diagnostic competence. Slovak and Ukrainian teacher students involved in the research demonstrated satisfaction with their diagnostic competence and its components, diagnostic activities and diagnostic accuracy. No statistically significant differences were found between the components or student satisfaction.
\end{abstract}

Key words:

diagnostics, diagnostic competence, teacher training, micro-teaching

\section{Úvod}

Profilácia učitel'stva smerom k profesionalizácii je nevyhnutná už počas vysokoškolskej prípravy budúcich učitel'ov. Fenstermacher a Richardson (2005, s.205) svojim výskumom poukazujú, že kvalita učitel'a je v priamom vzt’ahu $s$ výsledkami žiakov. Zdôrazňujú zároveň, že zlepšovanie výučby učitel'a je klúčovým prvkom pri zlepšovaní vzdelávania žiakov. Do súvisu dávajú kvalitné vyučovanie s morálne obhájitel'nými a racionálnymi zásadami inštruktážnej práce učitel'a. Učitel'a považujú za najdôležitejšiu premennú v triede (Fenstermacher \& Richardson, 2005, s. 189; Sönmez, 2007, s. 252).

Pripravit' profesijne kvalitných učitel'ov pre potreby výchovy a vzdelávania v súčasnej spoločnosti je výzvou predovšetkým pre učitel'ské prípravky, pretože predpokladom rozvoja klúčových kompetencií žiakov (apel hodnotiacich správ OECD, TALIS, či PISA) je, aby samotní učitelia mali rozvinuté reflexívne myslenie a vysokú úroveň svojich profesijných kompetencií. V súčasnosti sú tak žiadúce mnohostranné inovácie s cielom budovat' reflexívny charakter profesijnej prípravy budúcich učitel'ov so zameraním sa na 
zavádzanie rôznych výcvikových a modelových simulácií školských situácií v rámci praktickej prípravy $v$ podmienkach fakúlt pripravujúcich učitel'ov.

Jednou z metód rozvoja profesijných kompetencií je mikrovyučovanie, pri ktorom si študent učitel'stva precvičuje činnosti súvisiace s výchovno-vzdelávacím procesom a premýšla o svojej činnosti. Mikrovyučovanie zlepšuje nielen schopnosti študenta plánovat' vyučovací proces, znižovat' mieru stresu a zat'aženia študenta pri simulovanej výučbe, ale výrazne prispieva k profesijnému rozvoju učitel'a ako diagnostika a reflexívneho praktika.

Budúci učitel' by mal mat' na vysokej úrovni rozvinuté diagnostické schopnosti ako súčast' profesijných kompetencií. Schopnosti učitel'ov identifikovat' a interpretovat' relevantné situácie a udalosti, ktoré ovplyvňujú učenie študentov, sú nevyhnutné v oblasti prijímania efektívnych rozhodnutí počas vyučovania v triede. Učitel' sa v triede dostáva do situácií podobných s rolou lekára, ktorý pri procesoch identifikuje a interpretuje symptómy pacienta, aby sa rozhodol, ako pacienta najlepšie liečit' (Kramer et al., 2021). Aj učitel' je nútený posúdit' triedu, situácie a udalosti, aby mohol prispôsobit' svoju výučbu. Úroveň jeho diagnostických kompetencií je kritickým prvkom $v$ jeho vzdelávaní a preto je potrebné venovat' mu značnú pozornost' už počas pregraduálnej prípravy učitel'ov.

\section{Diagnostické kompetencie študentov učitel'stva}

V profesii učitel'a a pri jeho rozvoji osobnosti ako profesionála majú profesijné kompetencie nezastupitel'né miesto. Význam profesijných kompetencií učitel'a si uvedomujú i štáty Európskej únie, ktoré poukazujú na skutočnost', že učitel'ská profesia je špecifická vo vzt’ahu k iným profesiám v spoločnosti a je nevyhnutná štandardizácia profesijných kompetencií. Štandardizácia sa prejavuje v kontexte pedagogickej teórie, vzdelávacej politiky a pedagogickej praxe. Štandardizácia profesijných kompetencií je dôležitým procesom vyjadrenia normy pedagogických činností, ktoré sú preukázatel'né a zároveň sú vo vzájomnom prepojení bez výrazných konfliktov. Európska komisia (2012, s. 25 - 26) formulovala základnú štruktúru hlavných profesijných kompetencií učitel'a pre efektívne vyučovanie v 21. storočí v troch oblastiach: (a) vedomosti a porozumenie, (b) zručnosti, (c) dispozície (viera, postoje, hodnoty a záväzky).

Profesijné kompetencie učitela sa v slovenskom modeli fokusujú do troch oblastí: (1) žiak, (2) výchovno-vzdelávací proces a (3) profesijný rozvoj. V oblasti žiak sa prejavujú v schopnosti identifikovat' vývinové a individuálne charakteristiky žiaka, psychologické a sociálne faktory učenia sa žiaka a sociokultúrny kontext vývinu žiaka. V oblasti výchovnovzdelávací proces ide o schopnosti ovládat' obsah a didaktiku vyučovacích predmetov, plánovat' a projektovat' vyučovanie, realizovat' vyučovanie, hodnotit' priebeh a výsledky vyučovania a učenia sa žiaka. Oblast' profesijného rozvoja pokrýva schopnosti plánovat' a realizovat' svoj profesijný rast a sebarozvoj, stotožnit' sa s profesijnou rolou a školou (Pokyn ministra č. 39/2017). Diagnostické kompetencie sú preukázatel'né vo všetkých troch oblastiach.

Diagnostická kompetencia je definovaná ako schopnost' hodnotit' a analyzovat' individuálny výkon podla vopred definovaných kritérií. Učitel' s rozvinutou diagnostickou kompetenciou riadi vzdelávací proces a pochopenie toho, ktoré problémy s učením je potrebné riešit' (Richter, 2017). Diagnostické kompetencie pokrývajú celý proces diagnostiky, teda aj schopnosti používat' vhodné stratégie a metódy zberu a spracovania údajov, ako aj ich interpretáciu (Schradera, 2013). Efektívne diagnostikovanie edukačného správania sa žiaka počas vyučovacieho procesu je hlavným predpokladom schopnosti podporovat' rozvoj osobnosti žiakov. Správna diagnostika žiaka pomôže učitel'ovi prispôsobit' svoju edukačnú činnost' vo vzt'ahu k týmto žiakom a v konečnom dôsledku zlepšit' výkon žiakov. Primárnym účelom diagnostiky je zhromažd'ovat' informácie, ktoré umožnia konkrétne pedagogické rozhodnutia a činnosti učitela. Diagnostická kompetencia je teda prostriedkom na zlepšenie výkonu učitela (Kosirev, 
2011). Zároveň umožňuje učitel'ovi pochopit' ako myslia žiaci, a to i bez okamžitého procesu hodnotenia. Jej dôležitost' je značná v dvoch smeroch, a to pri potrebe analyzovat' myslenie a na udržanie vzdelávacieho procesu.

Pre rozvoj diagnostickej kompetencie je nevyhnutná schopnost' realizácie pedagogickej diagnostiky. Pedagogická diagnostika je nástrojom pri tvorbe pozitívnej klímy triedy plynúcej z navrhovania prostredia, ako i uspokojovania potrieb žiakov (Klug et al., 2013; Klug et al., 2016). Diagnostická kompetencia je spájaná s presnost’ou úsudku a vnímaná ako konzistentnost' hodnotenia (Martínez, Stecher, \& Borko, 2009).

Diagnostickú kompetenciu tvoria tri základné zložky: odborné schopnosti, diagnostické činnosti a diagnostická presnost' (obr. 1).

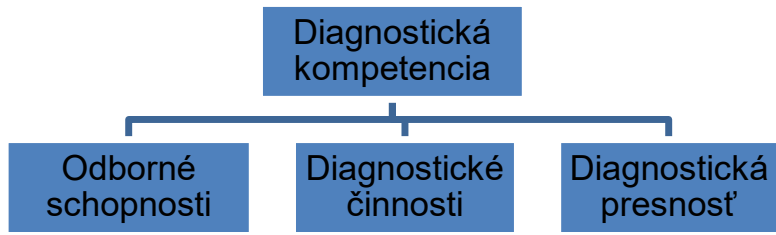

Obr. 1: Zložky diagnostickej kompetencie

(Zdroj: spracované podla Blömeke et al., 2015; Heitzmann et al., 2019)

Odborné schopnosti vychádzajú z kognitívnych dispozícii učitel'ov, sú zásadným predpokladom vykonávania diagnostických činností. V rôznych diagnostických situáciách učitelia uplatňujú svoje odborné schopnosti vo vzt'ahu k efektívnosti vyučovacieho procesu, diagnostikovania predstáv žiakov, ako i podpory ich učenia sa. Odborné schopnosti sa týkajú pedagogických a psychologických vedomostí, metód vyučovania, učenia sa a hodnotenia žiakov, poznatkov o riadení vyučovacieho procesu $v$ triede, o riadení triedy ako sociálnej skupiny. Tieto odborné schopnosti je možné rozvíjat' pri inštruktážnych situáciách a simulačných metódach vo výučbe budúcich učitel'ov, tak pri teoretickej profesijnej príprave ako i pri praktickej profesijnej príprave.

Príprava budúcich učitel'ov by vo vzt'ahu k požiadavkám učitel'skej profesie mala smerovat' k rozvoju i diagnostickej kompetencie študentov. Študenti by mali byt' schopní formovat' svoje úsudky a na ich základe vytvárat' efektívne rozhodnutia vo vzt'ahu k žiakom. Pre rozvoj diagnostickej kompetencie sa výcvikové a modelové simulácie školských situácií javia ako efektívny spôsob v rámci profesijnej prípravy budúcich učitel'ov.

\section{Mikrovyučovanie v podmienkach praktickej profesijnej prípravy}

Mikrovyučovanie radíme k simulačným metódam, pri ktorých ide o zjednodušenie (miniaturizácia) podmienok pre vyučovaciu činnost' učitel'a (Průcha, Walterová, \& Mareš, 2003). Mikrovyučovanie v podmienkach profesijnej prípravy budúcich učitel'ov znamená nácvik, precvičovanie učitel'ských zručností pomocou rôznych edukačných metód.

Mikrovyučovanie má svoje začiatky v rokoch 1956 - 1967 na Standfordskej univerzite, kedy ho profesor D.W. Allen a jeho pracovný tím použili $v$ programe prípravy učitelov tejto univerzity. Išlo takmer o laboratórnu prax vzdelávania učitel'ov v zjednodušených podmienkach bežných učební so žiakmi. Za základné znaky mikrovyučovania považuje Allen (1966) skrátené trvanie hodiny, použitie videa a poskytovanie spätnej väzby. Proces mikrovyučovania je založený na Kolbovom cykle učenia. 


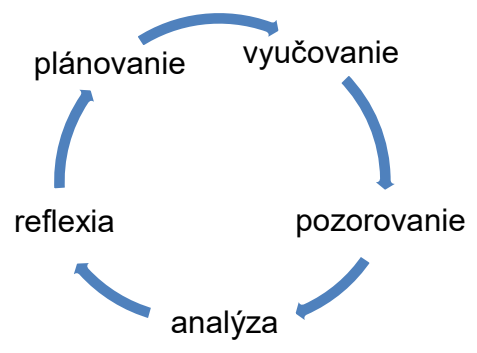

Obr. 2: Proces mikrovyučovania

(Zdroj: vlastné spracovanie)

Mikrovyučovanie ponúka nielen možnost' vyskúšat' si na istý časový úsek rolu učitela, ale pripravuje ho i na odstránenie sekundárnych t’ažkostí a problémov, ktoré študenti $\checkmark$ reálnych podmienkach majú, ako napríklad trémy, strach. Pomáha im dokonca zvyšovat' sebavedomie (Brown, 1975). Mikrovyučovanie v podmienkach pregraduálnej prípravy študentov učitel'stva je možné realizovat' tak vo všeobecných pedagogických disciplínach, ako i v predmetových didaktikách. Simulovaná výučba, jej riadenie a simulované situácie majú čo najviac zodpovedat' realite v školách.

Súčasné programy mikrovyučovania sú prispôsobované potrebám a špecifikám jednotlivých programov učitel'ského štúdia. Je však nutné dodržiavat' základné etapy (obr. 3):
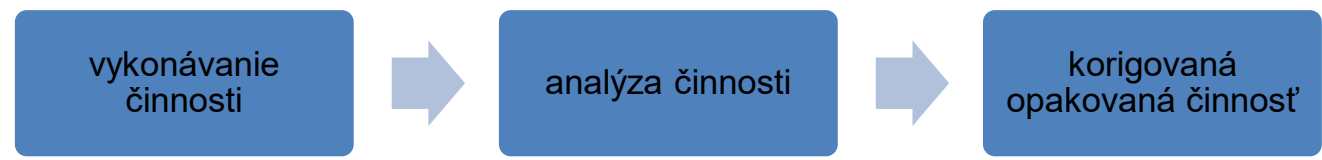

Obr. 3: Základné etapy mikrovyučovania

(Zdroj: spracované podla Bajtoš, \& Orosová, 2011, s.39)

Reflektujúc požiadavky súčasnej pedagogiky smerujúcej v príprave budúcich učitel'ov k reflexívnej výučbe a učitel'ovi ako reflexívnemu praktikovi s rozvinutými profesijnými kompetenciami a na základe vlastných skúseností sme v podmienkach UPJŠ inovovali mikroedukatívny model rozvoja profesijných kompetencií budúcich učitel'ov.

Inovovaný model má nasledovné etapy:

1. Úvodná príprava. Jej podstatou je pripravit' študenta na vyučovacie hodiny $\mathrm{s}$ využitím mikrovyučovania. Táto príprava prebieha $v$ dvoch podobách, na seminároch a $v$ rámci dištančných úloh.

2. Výber učiva. Úlohou študentov je výber učiva (témy) zo svojho aprobačného predmetu (z učiva základnej, resp. strednej školy), s ktorým budú počas mikrovyučovania pracovat'. Ide o oboznámenie sa s učivom, jeho didaktickú analýzu i oboznámenie sa s príslušnými pedagogickými a kurikulárnymi dokumentmi súvisiacimi s vybraným učivom.

3. Vol'ba etapy vyučovacej hodiny. $V$ tejto etape si študenti volia z etáp vyučovacej hodiny (resp. čast' etapy vyučovacej hodiny). Je možné využívat' i etapy stratégie EUR, bádatel'sky, zážitkovo, či inak orientovanej výučby. Etapy a podklady knim sú supervízorom zverejnené v moodle kurze (záznamy z prednášok, prezentácie, odkazy na dostupnú literatúru a i.).

4. Termín realizácie mikrovýstupu. Supervízor pripraví zoznam termínov realizácie a opakovanej realizácie mikrovýstupov študentov. Študenti sa hlásia sami na termín realizácie. 
5. Vykonávanie činnosti. Pred bezprostredným mikrovýstupom supervízor prerozdelí úlohy ostatným študentom. Vyberie študentov, ktorým pridelí rolu žiakov s individuálnymi výchovno-vzdelávacími potrebami. Úlohou týchto študentov bude počas mikrovýstupu hrat', prezentovat' správanie týchto žiakov podl'a základných prejavov individuálnych potrieb. Študent-učitel' pred začiatkom mikrovýstupu ozrejmí ostatným spolužiakom, aké učivo si vybral, pre ktorý ročník, ktorú etapu si vybral a ktoré vyučovacie metódy využije. Následne študent-učitel' vykonáva činnost', t.j. realizujú mikrovýstup v rozsahu $10-15$ minút. Jeho činnost' už nie je zaznamenávaná kamerou v učebni, ale jeden zo študentov vytvára videozáznam vlastným mobilným telefónom študenta-učitel'a. Počas mikrovýstupu sa do činnosti zapájajú i ostatní študenti v roli žiaka, prihliadajúc na špecifické vekové osobitosti žiakov.

6. Analýza činnosti (mikrovyučovacia analýza). Po ukončení mikrovýstupu študent-učitel' si v časovom limite 5 min. krátko zhodnotí pre seba svoju činnost' (krátka reflexia) na základe krátkych sebareflexívnych otázok. Ostatní študenti vytvoria skupiny cca po 4-5 študentoch, diskutujú navzájom o mikrovýstupe študenta a následne vyplnia spoločne záznam z mikrovýstupu študenta-učitel'a za skupinu. Nasleduje analýza mikrovýstupu formou rozhovoru, ktorú riadi supervízor. Najprv sa analyzuje a hodnotí sám študent-učitel', na základe sebareflexívneho záznamu pre rozhovor. Následne študenti z jednotlivých skupín a nakoniec supervízor. Po ukončení analýzy každý zo študentov vyplní svoj sebareflexívny záznam pre náčuv v rámci mikrovýstupu, ktorý je podkladom pre jeho pedagogický denník. Sebareflexia študenta-učitel'a pokračuje i v domácom prostredí, kde si znova prezrie videonahrávku svojho mikrovýstupu a opätovne vyplní sebareflexívny záznam z pozorovania a porovná ho s tým, ktorý vyplnil bezprostredne po mikrovýstupe v pedagogickom laboratóriu ako podklad pre rozhovor. Na základe výsledkov a taktiež odporúčaní supervízora a spolužiakov si pripraví opätovne mikrovýstup.

7. Korigovaná opakovaná činnost'. Študenti opätovne, ale už po zohl'adnení odporúčaní a vlastnej reflexii a sebareflexii činností $v$ rámci mikrovýstupu, opakujú mikrovýstup spolu s analýzou činnosti (mikroanalýzou) ako pri pôvodnom mikrovýstupe (bod 6).

Mikroedukatívny model rozvoja reflexívnych kompetencií má významnú úlohu pri praktickej profesijnej príprave študentov učitel'stva. Jeho realizácia bezprostredne pripravuje študentov pre pedagogickú prax, ktorú absolvujú v prostredí základných a stredných škôl.

\section{Metodológia}

Výskum bol zameraný na komparáciu profesijných kompetencií študentov učitel'stva na Slovensku a na Ukrajine. Ciel'om výskumu bolo zistit' mieru spokojnosti študentov učitel'stva s ich úrovňou profesijných kompetencií. Pre potreby tejto štúdie uvádzame výsledky výskumu zamerané na diagnostické kompetencie študentov učitel'stva.

Na deskripciu a analýzu názorov študentov učitel'stva sme použili variant deskriptívneho výskumu, ktorého ciel'om bolo zhromaždit' výskumný materiál podrobne opisujúci jednu ústrednú premennú, a to názory študentov učitel'stva na úroveň ich profesijných kompetencií. Študenti učitel'stva mali k dispozícii škálový hodnotiaci dotazník vlastnej tvorby, v ktorom sa vyjadrovali k jednotlivým položkách zameraným na diagnostikovanie a hodnotenie činnosti študenta-učitel'a pomocou pät'stupňovej Likertovej škály (1 - úplne nespokojný; 2 - skôr nespokojný; 3 - spokojný aj nespokojný; 4 - skôr spokojný; 5 úplne spokojný). 
Konštruktovú validitu sme overovali exploračnou faktorovou analýzou (PCA s varimaxovou rotáciou). Položky dotazníka sme podrobili exploračnej faktorovej analýze pomocou SPSS Statistics 20. Jej vhodnost' použitia sme zistili Kaiser-Meyer-Olkinovým (KMO) testom a Bartlettovým testom sféricity. Hodnota KMO testu miery adekvátnosti výberu bola 0,799 , čo môžeme považovat' za vel'mi dobrú (Hutcheson \& Sofroniou, 1999). Bartlettov test sféricity vyvrátil hypotézu, že je korelačná matica maticou jednotkovou $(p<0,001)$. Výsledky testov nám umožnili využívat' exploračnú faktorovú analýzu pri identifikácii dimenzionality nástroja a posúdení hodnosti zaradenia jednotlivých položiek dotazníka do d'alších analýz. Kritériom pre vhodnost' položiek bol koeficient komunality a minimálna faktorová zát’až položky pre jej zaradenie do jedného z faktorov 0,40. Reliabilitu (spol'ahlivost'), vnútornú konzistenciu výskumného nástroja, teda vzt'ah medzi položkami výskumného nástroja navzájom a vzt'ah medzi položkami a výskumným nástrojom ako celkom sme zist'ovali štatistickým softvérom SPSS Statistics 20, prostredníctvom Cronbachovho koeficientu alpha. Hodnotiaci dotazník vykazoval vel'mi dobrú reliabilitu, hodnota koeficientu Cronbachovho koeficientu alpha $\alpha=0,785$ bola nad minimálnou hodnotou $\alpha=0,700$. Korelácie medzi jednotlivými položkami sa pohybovali $v$ rozmedzí $<0,042 ; 0,763>$, pričom boli štatisticky významné na hladine významnosti $p<0,05$. Korelácie medzi jednotlivými položkami a celkovým skóre sa pohybovali vo všetkých prípadoch nad hranicou 0,50 . Všetky položky sme tak mohli zaradit' do d'alších analýz a nemuseli sme žiadnu vyradit'. Na základe hodnoty Spearmanovho koeficientu korelácie možno povedat', že medzi dimenziami existuje silná korelácia $(p<0,001)$. Výsledky faktorovej analýzy spolu s hodnotami koeficientu Cronbachovho alfa indikujú vnútornú konzistenciu jednotlivých faktorov.

\section{Charakteristika výberového súboru}

Základný súbor tvorili študenti učitel'stva na Univerzite P.J.Šafárika v Košiciach (Slovensko) a Mukačevskej štátnej univerzite v Mukačeve (Ukrajina), ktorí absolvovali mikrovyučovanie a inovovaný mikroedukatívny model rozvoja profesijných kompetencií. Výberový výskumný súbor bol tvorený študentmi učitel'stva z oboch krajín, ktorí sa dobrovol'ne anonymne zapojili do výskumu. Výberový výskumný súbor pre realizáciu dotazníkového šetrenia tvorilo 75 slovenských študentov učitel'stva a 37 ukrajinských študentov učitel'stva.

\section{Výsledky výskumu}

Ked’že vzorka skúmaných študentov bola pomerne malá, sumovali sme odpovede: nespokojný = 1 (úplne nespokojný) + 2 (skôr nespokojný); spokojný = 4 (skôr spokojný) + 5 (úplne spokojný). Študenti vyjadrili svoju spokojnost', resp. nespokojnost' so spôsobom získavania podkladov k hodnoteniu (diagnostické činnosti) a vlastným hodnotením (diagnostická presnost').

Slovenskí študenti boli spokojní so svojimi diagnostickými činnost’ami, ktoré realizovali po mikrovýstupe priamo v školskej praxi počas realizácie pedagogickej praxe $(74,66 \%$ študentov). Nespokojných bolo $6,67 \%$ slovenských študentov. $75,68 \%$ ukrajinských študentov bolo spokojných so svojimi diagnostickými činnost'ami a iba jeden študent bol nespokojný $(2,70 \%)$. Úroveň spokojnosti s hodnotením a celkovú diagnostickú presnost' slovenskí študenti vyjadrili nižšie, spokojných bolo 60,00 slovenských študentov a $67,57 \%$ ukrajinských študentov. Z uvedeného vyplýva, že študenti vnímajú svoju schopnost' realizovat' diagnostiku pozitívnejšie ako samotný proces hodnotenia (tab. 1). 
Tab. 1: Spokojnost' študentov v zložkách diagnostickej kompetencie

\begin{tabular}{|c|l|c|c|c|c|c|c|}
\hline \multicolumn{2}{|c|}{} & \multicolumn{2}{c|}{ nespokojný } & \multicolumn{2}{c|}{ spokojný aj nespokojný } & \multicolumn{2}{c|}{ spokojný } \\
\cline { 2 - 8 } \multicolumn{2}{|c|}{} & $\mathrm{N}$ & $\%$ & $\mathrm{~N}$ & $\%$ & $\mathrm{~N}$ & $\%$ \\
\hline \multirow{3}{*}{ SK } & Diagnostické činnosti & 5 & 6,67 & 14 & 18,67 & 56 & 74,66 \\
\cline { 2 - 8 } & Diagnostická presnost' & 9 & 12,00 & 21 & 28,00 & 45 & 60,00 \\
\hline \multirow{2}{*}{ UA } & Diagnostické činnosti & 1 & 2,70 & 8 & 21,62 & 28 & 75,68 \\
\cline { 2 - 8 } & Diagnostická presnost' & 1 & 2,70 & 11 & 29,73 & 25 & 67,57 \\
\hline
\end{tabular}

Legenda: SK - slovenskí študenti; UA - ukrajinskí študenti

(Zdroj: vlastné spracovanie)

Študenti prejavili spokojnost' so svojimi diagnostickými činnost'ami počas pedagogickej praxe. Z jednotlivých odpovedí vyplynulo, že študenti vnímajú svoju pripravenost' využívat' diagnostické činnosti pozitívne. Podla ich názorov dokážu v oblasti výchovnovzdelávací proces tvorit' didaktické testy, realizovat' testovanie, overovat' vedomosti a zručnosti žiakov, taktiež dokážu diagnostikovat' žiakov a rešpektovat' ich osobitosti pri príprave vyučovacej hodiny.

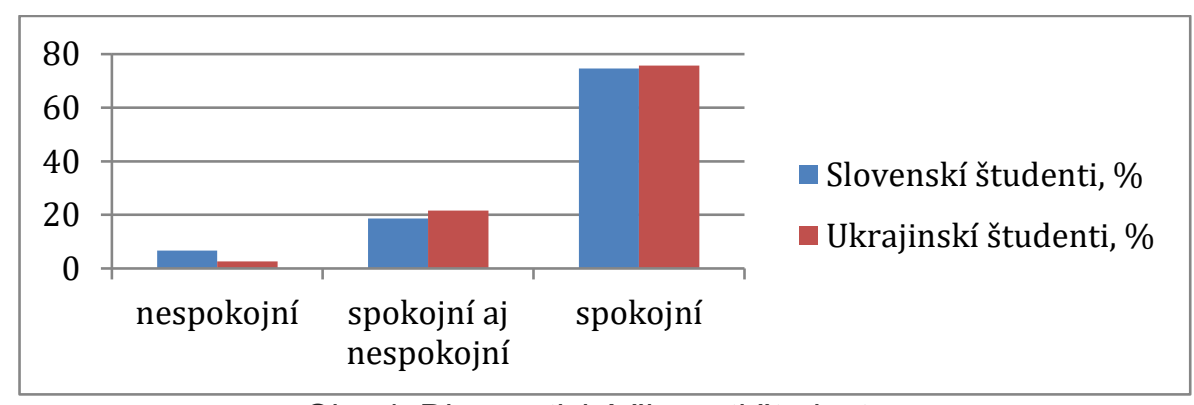

Obr. 4: Diagnostické činnosti študentov

(Zdroj: vlastné spracovanie)

Ukrajinskí študenti vyjadrili vyššiu mieru spokojnosti so svojimi diagnostickými činnost'ami ako slovenskí študenti, ale rozdiel bol vel'mi malý (obr. 4). 74,66\% slovenských študentov a $75,67 \%$ ukrajinských študentov je spokojných so svojou vlastnou schopnost'ou realizovat' diagnostické činnosti. Hodnota kritéria $x^{2}$ je 0,840 (počet stupňov vol'nosti je 2; kritická hodnota $x^{2}$ na hladine významnosti $p<0,05$ je 5,991). Rozdiel medzi študovanými vzorkami študentov na tomto základe nie je štatisticky významný; hladina významnosti je $p>0,05$. Úroveň významnosti $p=0,657$. Štatistická verifikácia hypotézy: Slovenskí študenti sú preukazujú štatisticky významne vyššiu spokojnost' so svojimi diagnostickými činnostami, sa na hladine významnosti 0,05 nepotvrdila. Medzi slovenskými a ukrajinskými študentmi nie sú štatisticky významné rozdiely vo vnímaní svojich diagnostických činností.

Študenti prejavili spokojnost' $s$ úrovňou svojej diagnostickej presnosti počas pedagogickej praxe. Z jednotlivých odpovedí vyplynulo, že študenti vnímajú svoju pripravenost' správne a efektívne hodnotit' pozitívne. Podl'a ich názorov dokážu hodnotit' výsledky diagnostického procesu v oblasti žiak i v oblasti výchovno-vzdelávací proces, avšak nižšie ako svoje diagnostické činnosti. 


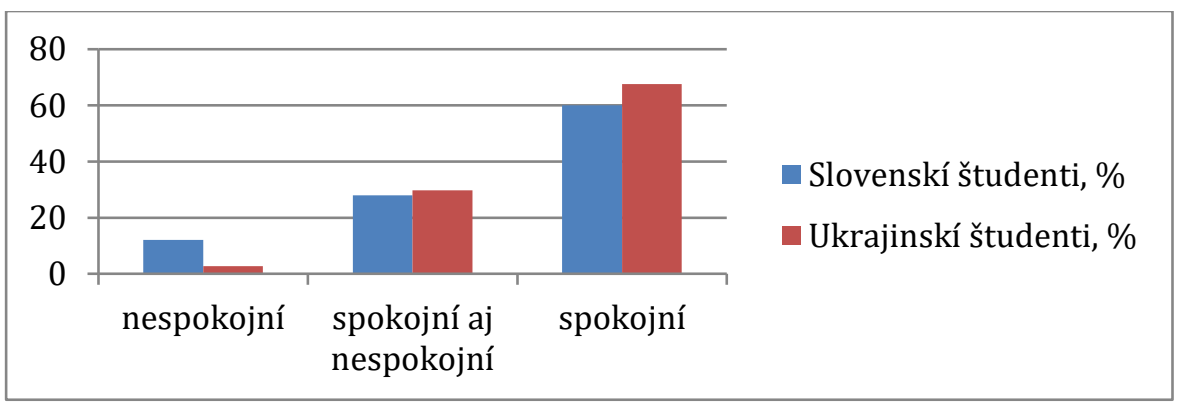

Obr. 5: Diagnostická presnost' študentov

(Zdroj: vlastné spracovanie)

Ukrajinskí študenti opätovne vyjadrili vyššiu mieru spokojnosti so svojimi diagnostickou presnost'ou ako slovenskí študenti, ale rozdiel bol vel'mi malý (obr. 5). 60,00\% slovenských študentov a $67,57 \%$ ukrajinských študentov vyjadruje spokojnost' so svojou vlastnou schopnost'ou hodnotit' vzdelávacie výsledky žiakov. Hodnota kritéria $x^{2}$ je 2,652 (počet stupňov vol'nosti je 2; kritická hodnota $X^{2}$ na hladine významnosti $p<0,05$ je 5,991). Rozdiel medzi študovanými vzorkami študentov na tomto základe nie je štatisticky významný; hladina významnosti je $p>0,05$. Úroveň významnosti $p=0,266$. Štatistická verifikácia hypotézy: Slovenskí študenti preukazujú štatisticky významne vyššiu spokojnost' so svojou diagnostickou presnost'ou, sa na hladine významnosti 0,05 nepotvrdila. Medzi slovenskými a ukrajinskými študentmi nie sú štatisticky významné rozdiely vo vnímaní svojej diagnostickej presnosti.

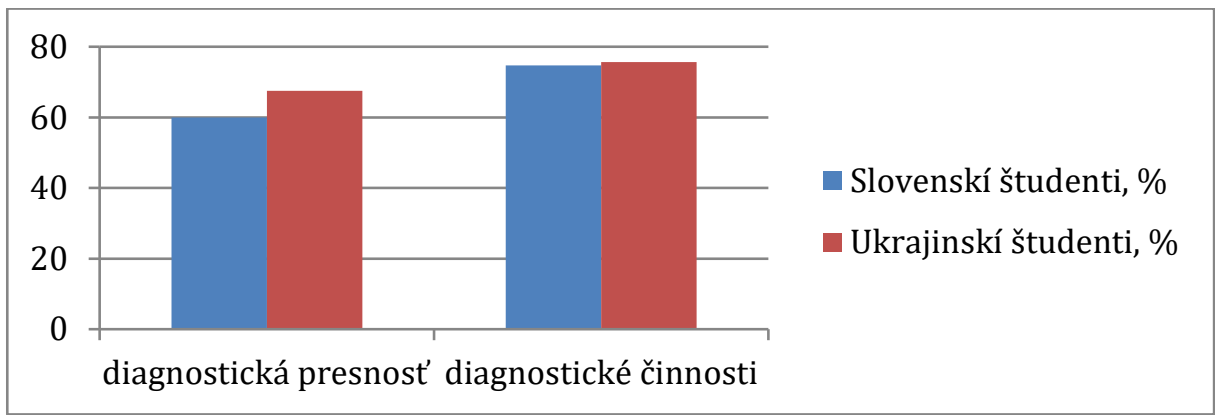

Obr. 6: Diagnostická kompetencia študentov

(Zdroj: vlastné spracovanie)

Percentuálne porovnanie získaných výsledkov ukrajinských a slovenských študentov, pokial' ide o diagnostickú kompetenciu, ukazuje, že pre obe skupiny je zložitejšie vykonat' diagnostickú presnost' (hodnotenie) ako diagnostické činnosti (testovanie, overenie). Konkrétne percentuálny rozdiel oboch zložiek diagnostickej kompetencie je u slovenských študentov rozdiel $14,66 \%$ a u ukrajinských študentov $8,11 \%$. Tento rozdiel však nebol štatisticky významný a medzi vnímaním a sebahodnotením svojej diagnostickej kompetencie slovenských a ukrajinských študentov nie je rozdiel.

\section{Diskusia a záver}

Reformné zmeny a proces profesionalizácie učitel'skej profesie je smerovaný k zvýšeniu kvality výchovno-vzdelávacieho procesu a kvality samotného učitel'a. Profesijné kompetencie učitel'ov sú indikátorom profesijného rozvoja a zvyšovania kvality výučby (Barber \& Mourshed, 2007; Hargreaves, 2009; Paine \& Schleicher, 2011). Jedným z faktorov zvyšovania tejto kvality je reflexia a reflexívny prístup k týmto procesom. 
Budúcim učitel'om je v procese ich prípravy potrebné vytvárat' podmienky na rozvoj ich profesijných kompetencií. Jednou z možností je metóda mikrovyučovania, ktorá podporuje rozvoj nielen reflexívnych kompetencia, ale i diagnostických.

Diagnostická kompetencia je nevyhnutnost'ou učitel'ov v procese prípravy a realizácie vyučovacieho procesu, ako i v príprave procesu overovania a hodnotenia vedomostí, zručností a výkonov žiakov. Mikrovyučovanie ponúka priestor pre simuláciu diagnostických javov. Študent-učitel' má vytvorené podmienky na diagnostické činnosti a hodnotenie. $V$ prostredí školskej praxe počas svojej pedagogickej praxe je nútený tieto diagnostické kompetencie preukazovat'. Ciel'om štúdie bolo prispiet' k vzdelávaniu učitel'ov skúmaním ich reflexie pripravenosti na proces diagnostiky a reflexie vlastnej úrovne diagnostickej kompetencie slovenských a ukrajinských študentov učitel'stva, ktorí absolvovali inovovaný model rozvoja profesijných kompetencií.

Aplikácia hodnotiacich prístupov počas mikrovyučovania umožňuje presné meranie skutočných praktických kompetencií učitel'ov, ako aj hodnotenie efektívnosti programov prípravy učitel'ov (Kunter, 2011). Budúci učitelia si v procese mikrovyučovania osvoja nielen techniky reflexie a sebareflexie, ale i techniky diagnostiky žiakov a činností, ktoré v školskej praxi následne aplikujú.

Ukrajinskí študenti preukázali vyššiu spokojnost' s úrovňou svojich diagnostických činností i úrovňou diagnostickej presnosti. Štatisticky však tento rozdiel nebol významný. Študenti oboch krajín preukázali značnú spokojnost' so svojou diagnostickou kompetenciou, ktorú rozvíjali i počas pedagogickej praxe v rámci praktickej profesijnej prípravy.

Ako uvádzajú Lightfoot \& Frost (2015) je ranná formácia profesionálnej identity u pedagógov viacrozmerná, komplexná a nemožno ju zredukovat' na zoznam osobných charakteristík, povinností a zodpovedností. Je potrebné využívat' v pregraduálnej príprave rôzne prístupy k rozvoju kompetencií, ktoré sú založené na aktívnom učení (Kunter et al., 2013). Klúčovým elementom je i výučba základov sebareflexie ako súčast' efektívnej prípravy učitel'ov, ked'že sa predpokladá, že reflexia je nevyhnutná pre profesionálny rozvoj (Klug et al., 2016).

Heinrichs \& Kaiser (2018) zdôraznili dôležitost' praktických skúseností pri formovaní diagnostickej kompetencie $v$ chybových situáciách. Tieto chybové situácie nastávajú i počas mikrovyučovania, kedy študent-učitel' môže nesprávne diagnostikovat' žiaka, ale nemá to priamy dopad na osobnost' žiaka, ked'že ide o simulačnú metódu a žiacke role sú hrané.

Táto štúdia priniesla zistenia smerujúce k pozitívnemu vplyvu mikrovyučovania na rozvoj diagnostickej kompetencie študentov učitel'stva, avšak má aj obmedzenia. Výskumná skupina predstavovala pomerne malú výskumnú vzorku, ktorá však bola ovplyvnená dostupným výberom. Mohli sa zapojit' iba študenti, ktorí mikrovyučovanie absolvovali. $\checkmark$ d'alších výskumných šetreniach odporúčame realizovat' pedagogický experiment, pri ktorom by výskumnú vzorku tvorila experimentálna (mikrovyučovanie absolvoujúca) skupina a kontrolná (mikrovyučovanie neabsolvujúca) skupina.

\section{Literatúra}

Allen, D. W. (1966). Micro-teaching: A new framework for in-service education. The High School Journal, 49, 355-362.

Bajtoš, J., \& Orosová, R. (2011). Mikrovyučovanie v pregraduálnej príprave učitelov. Košice: Univerzita Pavla Jozefa Šafárika v Košiciach.

Barber, M., \& Mourshed, M. (2007). How the world's best-performing school systems come out on top. McKinsey \& Company. http://mckinseyonsociety.com/how-the-worldsbest-performing-schools-come-out-on-top/

Blömeke, S.; Kaiser, G.; Clarke, D. Preface for the Special Issue on "Video-Based Research on Teacher Expertise". Int. J. Sci. Math. Educ. 2015, 13, 257-266. 
Brown, G. (1975). Microteaching a programme of teaching skills. London: Methuen. European Commision. (2012). Key data od education in Europe 2012. Key Data Series. $\begin{array}{lllll}\text { Eurydice. } & \text { [online]. } & 212 & \text { p. } & \text { Dostupné }\end{array}$ http://eacea.ec.europa.eu/education/eurydice/documents/key data series /134EN.pdf. Fenstermacher, G. D., \& Richardson, V. (2005). On making determinations of quality in teaching. Teachers College Record, 107(1), 186-213.

Hargreaves, L. (2009). The status and prestige of teachers and teaching. In Saha, L.J., \& Dworkin, A.G. (Eds.), International handbook of research on teachers and teaching, 217-229. New York: Springer.

Heinrichs, H., \& Kaiser, G. (2018). Diagnostic competence for dealing with students' errors: Fostering diagnostic competence in error situations. Diagnostic competence of mathematics teachers (pp. 79-94). Cham: Springer.

Heitzmann, N.; Seidel, T.; Opitz, A.; Hetmanek, A.;Wecker, C.; Fischer, M.R.; Ufer, S.; Schmidmaier, R.; Neuhaus, B.J.; Siebeck,M.; et al. (2019). Facilitating Diagnostic Competences in Simulations: A Conceptual Framework and a Research Agenda for Medical and Teacher Education. Frontline Learn. Res. 2019, 7, 1-24.

Klug, J., Bruder, S., \& Schmitz, B. (2016). Which variables predict teachers' diagnostic competence when diagnosing students' learning behavior at different stages of a teacher's career? Teachers and Teaching Theory and Practice, 22(4), 461-484.

Klug, J., Bruder, S., Kelava, A., Spiel, C., \& Schmitz, B. (2013). Diagnostic competence of teachers. A process model that accounts for diagnosing learning behavior tested by means of a case scenario. Teaching and Teacher Education, 30, 38-46.

Kosirev, V. N. (2011). A psychological model of diagnostic competence of the doctor. Medical Psychology in Russia: Electronics Scientific, 1(6). Retrieved from http://www.medpsy.ru/mprj/archiv global/2011 1 6/nomer/nomer08.php.

Kramer, M.; Förtsch, C.; Seidel, T.; Neuhaus, B.J. (2021). Comparing two constructs for describing and analyzing teachers' diagnostic processes. Studies Educ. Eval. 2021, 28.

Kunter, M. (2011). Theory meets practice in teacher education - Commentary. German Journal of Educational Science, 22, 107-112.

Kunter, M., Klusmann, U., Baumert, J., Richter, D., Voss, T., \& Hachfeld, A. (2013). Professional competence of teachers: Effects on instructional quality and student development. Journal of Educational Psychology, 105(3), 805-820.

Lightfoot, S., \& Frost, D. (2015). The professional identity of early years educators in England: implications for a transformative approach to continuing professional development. Professional Development in Education, 41(2), 401-418.

Martínez, J. F., Stecher, B., \& Borko, H. (2009). Classroom assessment practices, teacher judgments, and student achievement in mathematics: Evidence from the ECLS. Educational Assessment, 14(2), 78-102.

Richter, T. (2017). The structure of professional competence of teachers of mathematics. Physical and Mathematical Education, 1(11), 89-92.

Schrader, F.-W. (2013). Diagnostische Kompetenz von Lehrpersonen [Teacher Diagnosis and Diagnostic Competence]. Beiträge Zur Lehr. 31, 154-165.

Paine, S. L., \& Schleicher, A. (2011). What the U.S. can learn from the world's most successful education reform efforts. New York: McGraw-Hill Research Foundation.

Pokyn ministra č. 39/2017, ktorým sa vydávajú profesijné štandardy pre jednotlivé kategórie a podkategórie pedagogických zamestnancov a odborných zamestnancov škôl a školských zariadení.

Průcha, J., Walterová, E., \& Mareš, J. (2009). Pedagogický slovník. Praha: Portál. Sönmez, V. (2007). Ögretim ilke ve yöntemleri (Teaching principles and methods). Ankara: Ani Yayincilik. 


\section{Adresy autorov}

\section{Prof. Volodymyr Starosta, DrSc.}

Katedra pedagogiky, Filozofická fakulta UPJŠ Moyzesova 9, 04159 Košice

volodymyr.starosta@upjs.sk

Doc. PaedDr. Renáta Orosová, PhD. Katedra pedagogiky, Filozofická fakulta UPJŠ Moyzesova 9, 04159 Košice

renata.orosova@upjs.sk 


\title{
AKTIVIZUJÚCE METÓDY AKO NÁSTROJ ROZVÍJAJÚCI TVORIVÉ A KRITICKÉ MYSLENIE
}

\section{ACTIVATIONAL METHODS AS A TOOL FOR DEVELOPING CREATIVE AND CRITICAL THINKING}

\author{
Lenka Šutovcová \\ Katedra pedagogiky, Pedagogická fakulta, UKF v Nitre
}

\begin{abstract}
:
The development of students' creative and critical thinking is associated with the various methods and procedures that simplify and improve this process. One of the possibilities for achieving a higher level of creative and critical thinking is the application of activational methods, which help students to acquire knowledge in an active way based on their own cognitive activity. The main purpose of these methods is to change the educational process characteristic by stereotypical and monologic elements into a dynamic form which can help students and increase their interest. In this paper we deal with the potential contribution of selected activating methods for the development of creative and critical thinking of students. We focus on the theoretical characteristics of methods and we evaluate their importance in the development of these key competencies. The aim of the paper is to point out the potential and importance of activational methods in the process of developing creative and critical thinking of students through a theoretical summary of various professional works.
\end{abstract}

Key words:

activational methods, creative thinking, critical thinking

\section{Úvod}

Súčasná doba je sprevádzaná technologickým pokrokom, prudkým rastom poznatkov a informácií, ktoré výrazne ovplyvňujú každodenný život človeka. Informačná spoločnost' si vyžaduje disponovat' schopnost'ou flexibilne, tvorivo, kriticky a podnetne pristupovat' k rôznym informáciám a životným situáciám. S uvedenými skutočnost'ami súvisia aj meniace sa požiadavky na edukáciu v školách, ktoré musíme implementovat' do nášho systému vzdelávania. Tradičné a zaužívané metódy vzdelávania, ktoré sa dlhé roky bežne využívali sa menia z dôvodu toho, aby bol žiak schopný adaptovat' sa na rýchlo meniace potreby spoločnosti. Na základe uvedeného je potrebné, aby učitelia poznali a ovládali dostatočné množstvo nových a inovačných metód, s ktorými dokážu stimulovat' rozvoj tvorivého a kritického myslenia žiakov.

Jednou z hlavných výziev je vybavit' žiakov a študentov kompetenciou tvorivo a kriticky mysliet'. Snaha o presadzovanie rozvoja klúčových kompetencií žiakov prostredníctvom edukačného procesu v SR je dlhodobá a vychádza z Odporúčania Rady Európskej únie o klúčových kompetenciách pre celoživotné vzdelávanie, ktoré tvorí referenčný dokument pre členské krajiny Európskej únie (EÚ) v oblasti rozvoja vzdelávania, odbornej prípravy a učenia sa zameraného na kompetencie (Rada EÚ, 2018, In Borisová, Šutovcová 2019). Zoznam klúčových kompetencií v SR vymedzuje Štátny vzdelávací program SR, ktorý okrem rozvoja tvorivého a kritického myslenia definuje aj d'alšie 
kompetencie ako sú napr. komunikačné schopnosti a spôsobilosti, kompetencie v oblasti informačných a komunikačných technológií a i.

Úroveň rozvíjania tvorivého a kritického myslenia je determinovaná využívaním aktivizujúcich metód (Hosam, Hurmuzan, 2018; Kusumoto, 2018; Barrett, 2017; AlMutairi, 2015). Aktivizujúce metódy považujeme za motivujúce a inovatívne postupy, ktoré vd’aka svojim špecifickým vlastnostiam umožňujú samostatné riadenie poznávacej činnosti, a zároveň vedú vyučovanie tak, aby sa edukačné ciele dosahovali predovšetkým na základe vlastnej učebnej aktivity žiakov. $V$ tomto spôsobe edukácie dochádza $\mathrm{k}$ zmene postavenia žiakov z pasívnych recipientov na aktívnych účastníkov edukačného procesu v kognitívnych procesoch jednotlivca (Michel et al. 2009). Význam aktivizujúcich metód v procese rozvoja tvorivého a kritického myslenia spočíva v tom, že učenie žiakov prebieha prostredníctvom rozvoja predchádzajúcich znalostí a uplatňuje sa tu zmysluplné učenie dosahované prostredníctvom zážitku. Získané vedomosti majú trvalejší a hlbší charakter (Carbogim et al., 2019; Kotrba, Lacina, 2015).

V odbornej zahraničnej a slovenskej literatúre nachádzame množstvo aktivizujúcich a inovatívnych metód (Hosam, Hurmuzan, 2018; AlMutairi, 2015; Kotrba, Lacina, 2015; Hajrová, 2015; Buzan, 2014; Mistrík, 2014; Sitná, 2013; Tomengová, 2012; Zormanová; 2009; Maňák, Švec, 2003). V rámci príspevku upriamujeme pozornost' na vybrané aktivizujúce metódy, ktoré sa $v$ poslednej dobe častejšie spomínajú v súvislosti s rozvojom tvorivého a kritického myslenia. Zamerali sme sa najmä na metódu brainstorming, metódu pojmového mapovania a metódu problémového vyučovania. Ciel'om príspevku je prostredníctvom štúdia a analýzy rôznych informačných zdrojov a publikácií zosumarizovat' teoretické poznatky o vybraných aktivizujúcich metódach a poukázat' na ich potenciál a význam v procese rozvíjania tvorivého a kritického myslenia žiakov.

\section{Tvorivé a kritické myslenie $v$ edukačnom procese}

Ak hovoríme o rozvíjaní tvorivého a kritického myslenia $v$ edukačnom procese, rozumieme tým zvyšovanie schopnosti posúdit' nové informácie, pozorne, tvorivo a kriticky ich skúmat' z viacerých perspektív. Okrem uvedeného sa rozvíja schopnost' tvorit' si úsudky o vierohodnosti a hodnote informácií, ktoré dokážeme posúdit' pre svoje vlastné potreby (Grecmanová et al., 2000). Teoretickým východiskom tvorivého a kritického myslenia ako modelu vyučovania sa stala konštruktivistická teória výučby. Grecmanová et al. (2000) uvádza, že konštruktivizmus vychádza z teoretických poznatkov kognitívnej psychológie a výsledkov výskumu, ktoré študovali u žiakov rozvoj kognitívnych procesov - usudzovanie, analýza, riešenie problémov, tvorba konceptov či mentálnych obrazov. Konštruktivistický prístup je založený na fakte, že učenie má zmysel len v prípade, ak neprijíma študent hotové poznatky, ale konštruuje nové na základe tých, ktoré predtým prijal. Základom je síce prijatá informácia, ale človek si ju neukladá priamočiaro a mechanicky do pamäti. Naopak, pôvodné informácie transformuje, prehodnocuje, hl'adá súvislosti s doterajšími vedomost'ami o svete a vytvára si svoju vlastnú interpretáciu. Pri rozvíjaní tvorivého a kritického je potrebné si uvedomit', že kriticky mysliet' znamená premýšl'at' do híbky o informáciách, brat' do úvahy zdroje informácií, zvažovat' argumenty, väzby a súvislosti. Zmysluplné učenie predstavuje uvážlivé, starostlivé, zámerné a dôsledné rozhodovanie, ktoré sa opiera o určité vedomosti, intelektuálne zručnosti, osobnostné predpoklady, argumenty a dôvody rozvíjajúce sa praktickou činnost'ou (Klooster, 2000). Tak ako každá schopnost', aj tvorivé a kritické myslenie sa rozvíja len v aktívnej činnosti, v konkrétnych situáciách, z čoho vyplýva, že nevyhnutnou podmienkou jeho rozvoja je dat' žiakovi priestor a dostatok podnetov na to, aby dokázal tvorivo a kriticky mysliet', to znamená uchopit' myšlienku a dôsledne ju preskúmat', porovnat' s opačnými názormi, byt' zvedavý, používat' rôzne stratégie zist'ovania informácií, zadávat' otázky a systematicky hl'adat' odpovede (Grecmanová et al., 2000). 


\section{Aktivizujúce metódy}

Za účelom zvyšovania kvality výchovy a vzdelávania v Slovenskej republike sa neustále uskutočňujú snahy o zmeny v školstve (napr. nové štátne kurikulum), ktoré však nie sú zásadné a situáciu menia len čiastočne. Na nedostatky vo vzdelávaní a s tým súvisiacimi výsledkami našich žiakov sa poukazuje aj v rámci medzinárodných meraní PISA (2009, 2012, 2015, 2018), PIRLS (2006, 2011, 2016), ktoré priniesli neuspokojivé výsledky žiakov v oblasti gramotnosti. Okrem uvedeného poukazujú na skutočnost', že vyššie kognitívne funkcie, najmä samostatné, hodnotiace, tvorivé a kritické myslenie sú v slovenských školách rozvíjané nedostatočne. V súčasnej edukácii nestačí vyučovat' tradične, ale je potrebné aplikovat' inovatívne metódy, prístupy a spôsoby učenia (Kotrba, Lacina 2015).

Vhodným spôsobom pre rozvoj tvorivého a kritického myslenia v edukačnom procese je využívanie aktivizujúcich metód. Aktivizujúce metódy Michel et al. (2009) definujú ako didaktické postupy, ktoré vedú vyučovanie tak, aby sa edukačné ciele dosahovali predovšetkým na základe vlastnej učebnej aktivity žiakov. V tomto spôsobe edukácie dochádza k zmene postavenia žiakov z pasívnych recipientov na aktívnych účastníkov edukačného procesu. Dôležitost' aplikovania spomínaných metód vychádza z teórie psychológie učenia, že človek sa naučí niečo nové omnoho lepšie a rýchlejšie, ak si to sám vyskúša, t. j. bude aktívne zapojený do výučby. Opakom je pasívny náčuv, opakovanie a memorovanie fráz a faktov bez akéhokol'vek premýšl'ania. Edukačný proces využívajúci aktivizujúce metódy rozvíja:

- komunikačné schopnosti;

- $\quad$ sebaprezentáciu žiakov;

- schopnost' vhodne argumentovat', obhajovat' svoje názory;

- $\quad$ tvorivé a kritické myslenie (Mistrík, 2014; Kotrba, Lacina 2015).

Aktívnym učením sa kladie menší dôraz na sprostredkovanie informácií a väčší dôraz na rozvoj zručností žiakov vyžadujúc uplatnenie vyšších myšlienkových operácií (napríklad analýza, syntéza, hodnotenie). Okrem aktívnej činnosti sú žiaci nepriamo podnecovaní, aby rozmýšl'ali nad tým čo robia. Vedomosti žiakov získané vlastným aktívnym učením závisia od ich motivácie a ciel'ov, ale aj od toho, čo z danej témy už vedia a ako to dokážu využit' pri učení sa nových vecí (Michel et al. 2009). V procese rozvíjania tvorivého a kritického myslenia aktivizujúcimi metódami sa podla Tomengovej (2012) uplatňuje MODEL 3P (počiatočné faktory, proces aktívneho učenia sa žiakov a produkt, ako výsledok učenia sa žiakov). V počiatočných faktoroch prebieha identifikácia všetkého, čo bude dôležité $v$ procese učenia sa žiakov, pričom ide o dvojaké faktory - žiacke (relevantné predchádzajúce vedomosti žiakov k téme a záujem o ňu, schopnosti žiakov, význam témy vzhl'adom na študijné zameranie a iné) a učitel'ské (ciele, metódy vyučovania, skúšanie - hodnotenie, klíma, organizácia štúdia v škole a iné). Následne začína proces aktívneho učenia sa žiakov, ktorý sa ukončuje dosiahnutými výsledkami žiaka v tomto procese (nadobudnuté výsledky môžu byt': kvantitatívne -fakty, zručnosti; kvalitatívne - štruktúra, transfer a afektívne - aktívne zapojenie sa žiakov zaangažovanost' na plnení úloh).

Zrealizované výskumy od autorov ako napr. Carbogim et al. (2019), Hosam, Hurmuzan (2018), Kusumoto (2018), Barrett $(2017,2008)$, AlMutairi (2015) potvrdzujú, že človek si zapamätá ovel'a viac, ak využije v procese učenia viac zmyslových orgánov alebo niečo zažije, resp. si to sám vyskúša. Zážitok je potom silnejší a zanechá hlbšie pamätové stopy. S ciel'om zabezpečit' efektívne vyučovanie je potrebné dbat' na viacero prvkov vstupujúcich do tohto procesu. Pedagóg by mal v prvom rade viest' žiakov $\mathrm{k}$ tomu, aby sa vedeli slobodne rozhodovat' a mali možnost' vybrat' si. Treba im dat' priestor na tvorenie, spoluprácu a diskusiu. Pri uplatňovaní aktivizujúcich metód s dôrazom na rozvíjanie tvorivého a kritického myslenie je dôležité, aby učitel' mal na pamäti 
individualitu žiaka a neporovnával ho s inými žiakmi (Mistrík, 2014; Kotrba, Lacina, 2007).

\section{Vybrané aktivizujúce metódy}

$\checkmark$ kontexte riešenej problematiky približujeme vybrané aktivizujúce metódy, ktoré sa $\mathrm{v}$ poslednej dobe čoraz častejšie spomínajú v súvislosti s rozvojom tvorivého a kritického myslenia. Zamerali sme sa na nasledujúce metódy: brainstorming, pojmové mapovanie a problémové vyučovanie.

\section{Brainstorming}

Brainstorming znamená využívanie mozgu na aktívne a tvorivé riešenie problémov. Tvorivé riešenia problémov sú založené na kognitívnej teórii, pri ktorej sa uplatňuje modifikácia kognitívnej štruktúry (Chukwuemaka, 2017). Rowan (2014) definuje brainstorming ako skupinovú alebo individuálnu tvorivost', počas ktorej sa produkujú nové, originálne riešenia s ciel'om určenia definitívneho záveru konkrétneho problému. Myšlienka skupinovej práce bola pôvodne predstavená Osbornom v roku 1953, ktorý tvrdil, že jednotlivec pracujúci sám na vymýšl'aní nápadov, je menej efektívny, ako ked' sa tieto nápady vytvárajú prostredníctvom skupiny. Brainstorming je založený na dočasnom zámernom odblokovaní tvorivého a kritického myslenia pri súčasnom posilňovaní intuitívnych, ale aj náhodných zložiek myslenia. Hlavným ciel'om brainstormingu ako metódy vyučovania je rozvíjat' a zlepšovat' komunikačné zručnosti, zlepšovat' zručnosti $v$ oblasti myslenia a rozhodovania, ako aj podporovat' rôzne stanoviská a názory. Počas priebehu brainstormingu sa nové nápady nemajú posudzovat' ani analyzovat' z dôvodu obmedzenia tvorby myšlienok v tvorivom procese. Hodnotenie nápadov sa má uskutočňovat' na konci brainstormingu, kde je vytvorený priestor pre skúmanie a hodnotenie nápadov, čím sa stimuluje rozvoj kritického myslenia (AlMutairi, 2015).

Chukwuemaka (2017) vo svojej štúdii poukazuje na význam pri dosahovaní vynikajúcich výsledkov a o dôležitosti pri aplikovaní danej metódy z hladiska rozvíjania tvorivého a kritického myslenia pretože:

1. pomáha študentom riešit' problémy a ponúka im inovatívne riešenie;

2. pomáha študentom t'ažit' z myšlienok druhých prostredníctvom rozvoja a stavat' na nich;

3. pomáha súdržnosti študentov a buduje medzi nimi vzt'ahy a posudzuje názory ostatných.

Predchádzajúce štúdie viacerých autorov (napr. od Michinov et al. 2015; Drapeau, 2014; Schlee, Harich, 2014) potvrdzujú, že proces vytvárania nápadov zohráva výnimočnú úlohu pri stimulácii schopnosti jednotlivcov vytvárat' tvorivé riešenia, ktoré je možné d’alej hodnotit' a tým rozvíjat' kritické myslenie.

Podl'a AlMutairi (2015) má brainstorming dve dôležité a od seba výrazne oddelené fázy: fáza tvorby nápadov (divergentná fáza) a fáza kritického myslenia. $V$ divergentnej fáze sa produkujú netradičné a originálne nápady na riešenie problému. Vo fáze kritického myslenia sa tieto nápady kriticky hodnotia a prispôsobujú požadovaným kritériám. Samotný proces realizácie opisujú AlMutairi (2015); Rowan (2014); Sitná (2013); Zormanová (2009); Maňák, Švec (2003) rovnako a uvádzajú nasledovné časti:

1. oboznámenie žiakov s pravidlami brainstormingu;

2. napísanie problému na tabulu (prípadne môže problém učitel' sformulovat' so žiakmi);

3. samotná produkcia nápadov;

4. všetky nápady bez rozdielov (aj tie ktoré sa zdajú ako nereálne, nezmyselné, absurdné) sa zapisujú na viditel'né miesto;

5. zoznam nápadov sa dá na prístupné miesto a podrobí sa posudzovaniu;

6. diskusia a hodnotenie vymyslených nápadov. 
Počet účastníkov a doba trvania realizácie brainstormingu sa u rôznych autorov líši (Tab. 1). Rozmedzie počtu účastníkov je medzi 4 až 30 a doba trvania medzi 5 až 45 minút. $Z$ uvedeného vyplýva, že počet účastníkov a dobra trvania je podmienená rôznym okolnostiam, napr. v akej fáze sa uvádzaná metóda realizuje a pod.

Tab. 1: Rôzne parametre metódy brainstorming

\begin{tabular}{|c|c|c|}
\hline Autori & Počet účastníkov & Doba trvania \\
\hline Maňák, Švec, 2003 & $7-12$, alebo celá trieda & optimálne $30-45$ min \\
\hline Zormanová, 2009 & $5-8$, alebo celá trieda & optimálne $30-45$ min \\
\hline Sitná, 2013 & $4-30$ & priemerne $5-15$ min \\
\hline Hajrová, 2015 & neuvádza & priemerne $5-15$ min \\
\hline
\end{tabular}

Zdroj: vlastné spracovanie, 2020

Táto metóda si nevyžaduje žiadnu špeciálnu prípravu priestoru, učitel' môže pracovat' v triede s klasickým usporiadaním lavíc. Pre realizácii si učitel' vystačí s tabul'ou a kriedou (alebo písacími potrebami a papierom). Na ozvláštnenie edukačného procesu môžeme brainstorming uskutočňovat' napríklad prostredníctvom internetovej stránky Mentimeter (www.mentimeter.com, 2020). Učitel' sa musí najskôr zaregistrovat' na danej stránke a následne môže vytvárat' a zadávat' vhodné problémy riešenia. Žiaci produkujú svoje nápady po prihlásení cez internetový link, ktorý im pošle učitel'. Samotná realizácia prebieha ako za zvyčajných podmienok. Výhoda realizácie brainstormingu na internete spočíva $v$ tom, že nápady, ktoré vpisujú žiaci cez počítač sú anonymné, teda sa vyhýbame posudzovaniu tvorivých nápadov a kobmedzovaniu tvorby myšlienok $v$ tvorivom procese.

Brainstorming okrem kompetencie tvorivo a kriticky mysliet' rozvíja aj d'alšie klúčové kompetencie ako sú: kompetencia $\mathrm{k}$ riešeniu problémov, komunikatívna kompetencia, personálna a sociálna kompetencia (Hajrová, 2015).

Výskumné štúdie a odborné práce od autorov Hosam, Hurmuzan (2018); AlMutairi (2015); Hajrová (2015); Michinov et al. (2015); Drapeau (2014); Schlee, Harich (2014); Khodadady et al. (2011) potvrdzujú využitie metódy brainstorming ako efektívny prostriedok rozvíjajúci tvorivé a kritické myslenie.

\section{Pojmové mapovanie}

Pojmové mapovanie je jednou z metód na podporu učenia sa žiaka a získavanie nových poznatkov aktívnym spôsobom. Uvedená metóda nepatrí v našom školstve medzi bežné edukačné metódy na podporu a rozvoj učenia žiaka, zatial' čo v zahraničí, najmä v Amerike, tvorí pevnú súčast' didaktickej tradície (Gunišová, Kozárová, 2016). Metóda pojmových máp bola vyvinutá v roku 1972 Novakom na Cornellovej univerzite v USA (Novak, 2004).

Pojmové mapovanie je procesom konštruovania pojmovej mapy, ktorá umožňuje žiakom názorne zobrazit' vzt'ahy medzi myšlienkami, pojmami, slovami, predstavami, ktoré majú $v$ súvislosti s daným učivom alebo témou. Je to metóda učenia, testovania a zist'ovania vedomostí (Novak, Cañas, 2007).

Podla Fisher (2004) je pojmová, myšlienková alebo inak nazývaná mentálna mapa obrázok, ktorý znázorňuje spojitost' a vzt’ahy medzi poznatkami. Označenia pojmová, mentálna alebo myšlienková mapa chápu Karolčík, Murtinová (2013) ako synonymá. Vychádzajú z toho dôvodu, že niektoré použité pojmové mapy nemajú typickú štruktúru mentálnych máp, skladajú sa z viacerých úrovní a obsahujú význačné prepojenia vzt’ahy medzi niektorými pojmami. Pojmová mapa je založená na teórii, ktorá zdôrazňuje dôležitost' predchádzajúcich vedomostí pri učení sa nových pojmov a vzt’ahov. Systém poznatkov tvorí hierarchickú štruktúru pojmov a vzt’ahov medzi nimi. Nové pojmy sa 
stanú vedomost'ami až ked' sa aktívne začlenia už do existujúcich kognitívnych štruktúr. Podstata tejto metódy spočíva $v$ osvojovaní vzájomných vzt'ahov medzi pojmami predstavujúc grafickú reprezentáciu vedomostnej štruktúry žiaka z daného učiva, v ktorej body znázorňujú pojmy, spojnice a čiary (Gunišová, Kozarová, 2016). Mapovanie podnecuje k aktívnemu mysleniu, rozvíja schopnost' analyzovat', triedit' pojmy a hl'adat' medzi nimi spojitost' (Kotrba, Lacina, 2015).

Pojmová mapa zamestnáva pravú aj l'avú hemisféru, pretože sa v nich uplatňuje zobrazenie, predstavivost' v kombinácií so slovami, číslami a logikou. V priebehu tvorby pojmovej mapy podnecujeme synergické myslenie, prepájanie oboch hemisfér a tiež schopnost' tvorby asociácií, pretože všetky predstavy zachytené na pojmovej mape sú navzájom prepojené. Dôležitý pri práci s pojmovou mapou nie je len výsledok, ale aj proces jej tvorby (Bagalová a kol., 2015).

Pokial' človek pracuje s pojmovými mapami, každá nová informácia, ktorú mozog prijme sa automaticky prepojí so všetkými informáciami, ktoré tam už sú a prirodzeným spôsobom sa utriedia tak, aby bol ku ktorejkol'vek z informácií okamžitý prístup. Tvorba máp prispieva k tréningu mozgu. Čim viac sa snaží jednotlivec svoj mozog rozvíjat', venovat' sa učeniu a cvičit' pamät', tým zložitejšie a prepracovanejšie myšlienkové štruktúry v mozgu vznikajú. Pokial' medzi informáciami alebo predstavami nachádza jednotlivec asociácie, pomáhame svojmu mozgu vytvárat' spoje medzi nimi, a teda mysliet' (Buzan, 2014).

Z terminologického pohl'adu je odborná literatúra pomerne nejednoznačná a pojmové mapovanie môžeme aplikovat' ako stratégiu učenia sa (Novak, 2004), ale aj ako učitel'ovu stratégiu/metódu vyučovania (Marangos, Alley, 2007), prípadne ako stratégiu na hodnotenie žiakov (Rebich, Gautier, 2005) na základe toho, v akých súvislostiach sa o termíne vyjadruje. Ak hovoríme o učebných stratégiách, tak ide o postupy zlepšenia činností žiakov pri výbere učiva, jeho zapamätávania, uskladňovania $v$ pamäti $a$ následného vybavenia $v$ rámci intencií zmysluplného učenia. Je to hlavne metóda, ktorá samotnému žiakovi sprístupňuje jeho poznatky, chápanie alebo názory na nejakú tému (Petrasová, 2008).

V oblasti vzdelávania má pojmové mapovanie viacero možností využitia. Pre učitel'a môže byt' užitočným prostriedkom pri plánovaní vyučovacieho procesu, vytvorení zmysluplnej štruktúry učiva, výber klúčových pojmov a pod. V súvislosti so spomínaným Hubatka (2010; In Duchovičová, Kozárová, 2016) zosumarizoval viaceré praktické využitia pojmového mapovania v oblasti vzdelávania. Uvádza využitie pojmových máp napr. ako formu zápisu do zošita, ako formu samostatnej alebo skupinovej práce, ako podklad k diskusii, ako výstup pre referát, prezentáciu, plán projektu, činnosti, úlohy, hodiny (tvorba a následne realizácia plánu), pomôcka pre didaktickú prípravu učitel'a, či príprava na hodinu a pod.

Ak chce pedagóg začat' používat' pojmové mapy $v$ edukačnom procese, je dôležité, aby žiakov naučil ako sa pojmové mapy tvoria a ako sa s nimi pracuje. Existuje mnoho autorov (Novak, Cañas, 2008; Petrasová, 2008; Činka, 2012; Vaňková, 2014 a iní), ktorí uvádzajú jednotlivé kroky dôležité pri tvorbe pojmovej mapy, avšak všetky tieto postupy sú v podstate totožné. Petrasová (2003) uvádza všeobecný postup pri vytváraní pojmovej mapy: opísat' aktivitu a predviest' jednotlivé kroky pojmového mapovania; vybrat' zaujímavú tému pre účastníkov a modelovo predviest' postup v skupine; vybrat' druhú zaujímavú tému a vyhradit' čas na individuálnu prácu; vyhradit' priestor $4-5$ účastníkom na prezentovanie svojich asociácií pred skupinou; diskutovat' vo dvojiciach vybraných podla ročníkov alebo predmetu o použití pojmového mapovania na najbližšej vyučovacej hodine.

Pri pojmovom mapovaní sa za základ považuje výber klúčového pojmu. Po ňom nasleduje produkcia nových pojmov, ich zoradenie s využitím kategórií, zhrnutie - 
spojenie pojmov na rovnakej úrovni abstrakcie a tých, medzi ktorými existujú tesné väzby, a usporiadanie do diagramu - mapy. Pojmy sa na záver prepoja čiarami, nad ktoré sa zapíše forma súvislostí (Petrasová, 2003).

$\checkmark$ procese rozvoja tvorivého a kritického myslenia môžeme mapovanie použit' ako pomôcku pri vytváraní štruktúry a hierarchizácií medzi jednotlivými pojmami, implementovaní nových informácií do širšieho kontextu a vnútorného poznatkového systému, zapájaní oboch mozgových hemisfér pri procesoch učenia, divergentného, tvorivého, kritického a komplexného myslenia (Fisher, 2004). Žiaci si rozvíjajú vyššie kognitívne procesy pri využívaní pojmovej mapy tým, že napr. argumentujú, posudzujú, vyjadrujú svoje názory, hodnotia svoje a iné pojmové mapy. Ďalej, že si navrhujú, vytvárajú a zdokonal'ujú svoju pojmovú mapu, vymedzujú hlavné myšlienky v učive (Broggy, McClleland, 2008; Novak, Cañas, 2007). Petrasová (2008) uvádza, že sa môže použit' ako prostriedok stimulujúci myslenie pred podrobnejším preštudovaním témy, d'alej ako prostriedok k zhrnutiu prebraného učiva, ale aj pri budovaní nových asociácií alebo grafického zobrazenia nových poznatkov.

Metódu pojmového mapovania môžeme využit' pre celú triedu žiakov, bud' ako prácu jednotlivca alebo ako skupinovú prácu. Vhodnost' uplatnenia sa preferuje pre všetky vzdelávacie úrovne, je nenáročná pre prípravu učitela, žiaka, ale tak isto aj pre prípravu pomôcok. V súčasnosti nám informačno-komunikačné technológie vytvárajú priestor pre vytváranie myšlienkových máp v rôznych softvérových aplikáciách ako napr. MindMeister, Freeplane, SimpleMind, Xmind a mnohé iné. Podl’a Stančíkovej (2015) je efektívnejší, jednoduchší, grafický variabilný program s názvom iMindMap. Myšlienkové mapy sa dajú vytvárat' aj na internetových stránkach: www.bubbl.us; www.mindmeister.com; mind42.com; www.mapul.com.

Využitím uvádzanej metódy môžeme podporit' rozvoj kompetencií ako sú kompetencia učit' sa, komunikatívna kompetencia, sociálna kompetencia a kompetencia riešenia problémov (Buzan, 2014; Sitná, 2013; Harausová, 2011; Fisher, 2004).

Výskumné štúdie (Kuchárová, 2007; Broggy, McClleland, 2008; Doulík, Škoda, 2011; Duchovičová, Gunišová, 2015; Petrová, Kozárová, 2015; Stančíková, 2015 a iné.) poukazujú na fakt, že pojmové mapovanie je vysoko efektívnou aktivizujúcou metódou, ktorá rozvíja učebné činnosti žiaka, vd'aka čomu sa žiak zmysluplne učí a dosahuje lepší učebný výkon. Žiak vie identifikovat' kl'účové a relevantné fakty a myšlienky v učive, čím si rozvíja tvorivé a kritické myslenie, a zároveň sa posilňujú aj medzipredmetové vzt’ahy a spolupráca.

\section{Problémové vyučovanie}

Schopnost' riešit' problémy je nevyhnutné pre úspech $v$ rade aktivít $v$ každodennom živote. Žiaci disponujúci schopnost'ou riešit' problémy sú schopní tvorivo a kriticky pristupovat' pri riešení problémov vich živote. Problémové vyučovanie môže byt' chápané ako koncepcia (Turek 2014; Lázsló, Osvaldová, 2014; Kicová, 2015), ako organizačná forma (Lázsló, Osvaldová, 2014), ale aj ako metóda (Lázsló, Osvaldová, 2014; Kotrba, Lacina, 2015; Kosturková, 2016). Koncepcia vyučovania je širším pojmom ako pojem metóda vyučovacieho procesu. Zahŕňa $v$ sebe systematické používanie viacerých metód vyučovacieho procesu a rieši aj problematiku jeho niektorých d'alších činitel'ov, napr. podmienok vyučovacieho procesu, jeho ciel'ov, výberu učiva, didaktických zásad, organizačných foriem i materiálnych prostriedkov. Je súhrn názorov, či už teoretických alebo empirických, na povahu učenia, na riadenie učebnej činnosti a na usporiadanie učiva v rámci vyučovania (Lázsló, Osvaldová, 2014). V pedagogickom slovníku je problémové vyučovanie charakterizované ako vyučovacia metóda, resp. typ výučby, ktorý predpokladá riešenie problémov samotnými žiakmi. Ide o prostriedok intelektuálneho rozvoja (Průcha, Walterová, Mareš, 2008). Kotrba, Lacina (2015) radia 
problémové vyučovanie medzi inovatívne a aktivizujúce metódy, ktorá oživuje a zlepšuje edukačný proces. Táto metóda je v odbornej literatúre popisovaná ako vysoko efektívna metóda pri osvojovaní vedomostí. Metóda problémového vyučovania sa využíva priamo na vyučovacích hodinách, alebo $v$ mimoškolskej práci pri príprave žiakov na rôzne sút’aže. Od tradičného vyučovania sa líši vyučovaním, ktoré je založené na porozumení a riešení problémov a tým, že učitel' nesprostredkováva žiakovi hotové poznatky. $V$ tomto prípade je žiak nútený zvládnut' prekážky pri ich osvojovaní a hl'adaní. Teoretický základ danej metódy $\mathrm{k}$ získavaniu poznatkov pochádza z kognitivizmu, sociálneho konštruktivizmu a postmodernizmu. To znamená, že v rámci využívania metódy problémového vyučovania je učenie aktívny mentálny proces vychádzajúci z predchádzajúcich poznatkov, z tvorenia prepojení medzi starými a novými konceptmi prostredníctvom vypracovania rôznych vzt’ahov slúžiacich na zapojenie sa do konštrukcie teórie (Akigolu, Tandogan, 2007). V metóde problémového vyučovania študenti pracujú samostatne alebo $v$ malých skupinách, obvykle 4 až 6 jednotlivci a zvyčajne sa doba trvania pohybuje v rozmedzí 20 až 45 minút. $V$ rámci procesu sa učenie vníma ako niečo, čo vychádza zo samotnej činnosti učiacich sa a rola učitel'a facilitátora umožňuje a podporuje žiakov, aby konštruovali nové poznanie spoločne. Takéto metódy vedú žiakov k aktívnemu získavaniu nových vedomostí a zručností (Barret, 2017). V niektorých prípadoch môže dôjst' k tomu, že učitel' ponúka riešenie pri zavedení problémov žiakom s odôvodnením, aby podobné problémy vyriešili rovnakým spôsobom. Ak vychádzame $z$ daného názoru, tak žiaci si v procese učenia neprispôsobujú predchádzajúce vedomosti pri riešení nových problémov a nerozvíjajú si tvorivé a kritické myslenie (Hollingworth, McLoughlin 2001).

Podstata metódy problémového vyučovania spočíva vo vytváraní postupného radu problémových situácií a riadení činností žiakov pri viac-menej samostatnom riešení problémových úloh. Ciel'om je postavit' žiakov pred problém. Na vyriešenie problému je potrebné zapojit' rôzne myšlienkové procesy učiacich sa a objavovat' nové informácie. Jednotlivé činnosti nadväzujú na predchádzajúcu a výsledkom učenia je porozumenie problému a návrh jeho riešenia (Zormanová, 2009). Barrett (2017) vymedzuje nasledovné kroky procesu riešenia: konkretizovanie a nastolenie problému (môže vyplynút' z učiva; môže ho nastolit' učitel', alebo aj samostatní žiaci); analýza problému (založené na odlíšení podstatných a nepodstatných vecí); formulovanie hypotéz (orientovanie pozornosti na konečný ciel'); výber metód riešenia; riešenie problému; vyriešenie problému (vyriešením žiak dospel k novému poznaniu) a kontrola riešení (spočíva v overení výsledkov).

Kicová (2015) uvádza, že problémové vyučovanie v sebe zahŕňa niekol'ko názvov vyučovacích postupov a stratégií (napríklad heuristické vyučovanie, tvorivé vyučovanie, učenie objavovaním, riadené objavovanie, či pátracie vyučovanie). Ich spoločným znakom je snaha rozvíjat' tvorivé myslenie, tvorivé schopnosti žiakov, ich poznávaciu motiváciu a samostatnost', tvorivé osvojenie si poznatkov, spôsob činností a kritické myslenie.

Pri rozvíjaní tvorivého a kritického myslenia prostredníctvom metódy problémového vyučovania je nevyhnutné dodržiavat' jeho presné kroky. Kozárová, Gunišová (2019) považujú za základný atribút zadanie vhodného problému. V súvislosti s uplatnením metódy problémového vyučovania $v$ edukačnom procese s ciel'om rozvinút' tvorivé a kritické myslenie sa javí ako efektívne využitie napríklad stratégii DITOR (Kozárová, Gunišová, 2019). V jednotlivých krokoch žiaci pracujú samostatne alebo v skupinách. Pracujú na definovaní problému, informovaní sa o probléme analýzou rôznych zdrojov (internet, časopis, noviny, učebnica, encyklopédia), navrhujú a tvoria vlastné riešenia, overujú a realizujú navrhnuté postupy. Učitel' zastáva úlohu facilitátora a usmerňovatela. V rámci individuálnej práce žiak pracuje na probléme samostatne, hl'adá vhodné 
alternatívy a uplatňuje iba vlastné poznatky. Žiak prezentuje svoj vlastný názor a prijíma aj kritiku. Pri skupinovej práci dochádza ku konfrontácií a argumentácií žiakov medzi sebou. Všetky postupy a názory sú schval'ované ostatnými členmi skupiny a podrobené analýze. Pri metóde problémového vyučovania je dôležité vytvárat' pozitívnu atmosféru, v ktorej sa žiaci neboja vyjadrit' vlastné názory a postoje podporujúce ich sebadôveru a sebarealizáciu, pretože pod nátlakom sa žiakom znižuje ich tvorivost' v činnosti (Turek, 2014). Význam uplatnenia metódy $v$ edukačnom procese spočíva $v$ tvorivom riešení problémov a v rozvíjaní analytického myslenia. Žiaci sa učia kriticky rozmýšl'at' a využívat' vyššie myšlienkové operácie (Barrett, 2017).

Využívanie metódy problémového vyučovania v edukačnom procese má svoje prekážky prejavujúce sa v tom, že si jeho príprava vyžaduje viac času (Tab. 2). Ide o proces náročný na organizačné a manažérske schopnosti učitel'a alebo aj na jeho schopnosti predvídat' a flexibilne reagovat' na vzniknuté situácie (Turek 2014; Barrett 2017). Bridges (1992) uvádza vo svojich výskumných zisteniach dva dôvody, prečo je dobré využívat' danú metódu v edukačnom procese. Prvým dôvodom je zistenie, že tradičný spôsob učenia je neefektívny z hl'adiska uchovania poznatkov a druhým dôvodom apeluje na fakt, že naučené poznatky v tradičnom vyučovaní sú využívané nevhodne.

Prostredníctvom metódy problémového vyučovania sa zlepšujú nielen zručnosti týkajúce sa riešenia problémov, ale aj výskumné, sociálne a komunikačné zručnosti. Ďalšími výhodami realizácie je vzrastajúca motivácia k učeniu (Barrett, 2017, 2008).

Viaceré realizované výskumy (Kendler, Grove 2004; Sungur, Tekkaya 2006; Barrett 2008; Tsai, Shen, Lu 2015; Žáčok, Bernát 2016; Barrett, 2017) poukazujú na vyššiu efektívnost' problémového vyučovania v porovnaní s tradičným vyučovaním, prostredníctvom ktorého žiaci získavajú nové vedomosti vlastnou aktivitou a zároveň si rozvíjajú tvorivé a kritické myslenie.

\section{Sumarizácia vybraných aktivizujúcich metód}

$\mathrm{Na}$ základe štúdia a analýzy poznatkov z odbornej literatúry zaoberajúcou sa aktivizujúcimi metódami (Kotrba, Lacina, 2015, 2007; Michel et al. 2009 a iní) a metódami tvorivého a kritického myslenia (Hosam, Hurmuzan, 2018; AlMutairi, 2015; Buzan, 2014; Maňák, Švec, 2003 a iní.) sme zosumarizovali teoretické poznatky troch vybraných aktivizujúcich metód, ktoré $v$ súčasnosti patria medzi využívané metódy v procese rozvíjania tvorivého a kritického myslenia. Konkrétne sa jedná o brainstorming, pojmové mapovanie a metódu problémového vyučovania, ktoré sme bližšie charakterizovali a poukázali na ich význam v procese rozvoja tvorivého a kritického myslenia. Na význam aktivizujúcich metód v procese rozvoja tvorivého a kritického myslenia poukazujú viacerí zahraniční (Carbogim, et al. 2019; Kusumuto, 2018; Hosam, Hurmuzan, 2018; AlMutairi, 2015; Kotrba, Lacina, 2015; Maňák, Švec, 2003) a slovenskí autori (Sitná, 2013; Tomengová, 2012; Zormanová; 2009). Uvedení autori vyzdvihujú dôležitost' týchto metód v súvislosti s porozumením získaných poznatkov, s učením prostredníctvom rozvoja predchádzajúcich znalostí a s uplatňovaním zmysluplného učenia, ktoré sa dosahuje prostredníctvom zážitku. Títo autori poukazujú aj na trvalejší a hlbší charakter získaných poznatkov a vedomostí. Vybrané metódy sme charakterizovali a zhodnotili na základe viacerých parametrov (Tab. 2). Okrem rozvoja kl'účových kompetencií tvorivo a kriticky mysliet' sme sa zamerali aj na identifikáciu d'alších kompetencií, ktoré sa prostredníctvom využitia danej metódy rozvíjajú. Následne sme posudzovali každú metódu z hladiska počtu účastníkov, z časového intervalu jej realizácie, náročnosti prípravy pre učitela a žiaka, materiálnych podmienok a vhodnosti pre určitú vekovú skupinu. Odporúčaný časový interval realizácie jednotlivých metód závisí od zadania témy alebo od množstva zvolených skupín. Podobnost' jednotlivých metód sme zaznamenali najmä v časovej náročnosti prípravy študentov a vhodnosti pre každú vekovú skupinu, pričom pri vekovej skupine upozorňujeme na fakt, že je potrebné brat' do úvahy prispôsobenie témy alebo 
zadania tej vekovej skupine, pri ktorej ideme danú metódu aplikovat'. V rámci ukazovatel'ov - počet účastníkov a čas trvania je badatel'ná odlišnost' pri metóde brainstorming, pri ktorej uvádzajú viacerí autori rozličné údaje (Tab. 1). Vo všeobecnosti má každá z týchto aktivizujúcich metód svoje špecifiká, ale na základe analýzy viacerých publikácií môžeme potvrdit' ich význam a vhodnost' využitia v procese rozvíjania tvorivého a kritického myslenia.

Tab. 2: Porovnanie vybraných aktivizujúcich metód

\begin{tabular}{|c|c|c|c|}
\hline $\begin{array}{l}\text { Vybrané } \\
\text { parametre }\end{array}$ & Brainstorming & Pojmové mapovanie & $\begin{array}{l}\text { Problémové } \\
\text { vyučovanie }\end{array}$ \\
\hline $\begin{array}{c}\text { Rozvoj } \\
\text { kompetencií }\end{array}$ & $\begin{array}{l}\text { kompetencia riešenia } \\
\text { problémov (tvorenie } \\
\text { asociácií, návrhy } \\
\text { riešenia) } \\
\text { komunikatívna } \\
\text { kompetencia, sociálna } \\
\text { a personálna } \\
\text { kompetencia } \\
\end{array}$ & $\begin{array}{l}\text { kompetencia riešenia } \\
\text { problémov, } \\
\text { komunikatívna } \\
\text { kompetencia, } \\
\text { sociálna a personálna } \\
\text { kompetencia, kompet } \\
\text { encia učit' sa }\end{array}$ & $\begin{array}{l}\text { kompetencia } \\
\text { riešenia problémov, } \\
\text { komunikatívna } \\
\text { kompetencia, } \\
\text { sociálna } \\
\text { a personálna } \\
\text { kompetencia, komp } \\
\text { etencia učit' sa }\end{array}$ \\
\hline $\begin{array}{l}\text { Počet } \\
\text { účastníkov }\end{array}$ & $\begin{array}{c}\text { najnižší a najvyšší } \\
\text { odporúčaný počet } 1 \\
\text { až } 30 \text { členov }\end{array}$ & $\begin{array}{l}\text { najnižší a najvyšší } \\
\text { odporúčaný počet } 1 \\
\text { až } 6 \text { členov skupine }\end{array}$ & $\begin{array}{l}\text { najnižší a najvyšší } \\
\text { odporúčaný počet } 1 \\
\text { až } 6 \text { členov skupine }\end{array}$ \\
\hline Časový interval & $\begin{array}{c}\text { najmenší a najväčší } \\
\text { odporúčaný čas } 5 \text { až } \\
45 \text { min. }\end{array}$ & $\begin{array}{c}\text { najmenší a najväčší } \\
\text { odporúčaný čas } 5 \text { až } \\
30 \text { min. }\end{array}$ & $\begin{array}{c}\text { najmenší a najväčší } \\
\text { odporúčaný čas } 20 \\
\text { až } 45 \text { min. }\end{array}$ \\
\hline Veková skupina & $\begin{array}{l}\text { vhodné pre všetky } \\
\text { vekové skupiny }\end{array}$ & $\begin{array}{l}\text { vhodné pre všetky } \\
\text { vekové skupiny }\end{array}$ & $\begin{array}{l}\text { vhodné pre všetky } \\
\text { vekové skupiny }\end{array}$ \\
\hline Príprava učitel'a & nenáročná & nenáročná & náročná \\
\hline Príprava žiakov & nenáročná & nenáročná & nenáročná \\
\hline Pomôcky & $\begin{array}{l}\text { tabula, krieda, písacie } \\
\text { potreby }\end{array}$ & $\begin{array}{c}\text { každá skupina jeden } \\
\text { papier a písacie } \\
\text { potreby }\end{array}$ & $\begin{array}{l}\text { v závislosti od } \\
\text { problémovej } \\
\text { úlohy/situácií ktorú si } \\
\text { stanoví učitel' }\end{array}$ \\
\hline
\end{tabular}

Zdroj: vlastné spracovanie, 2020

\section{Záver}

Život $v$ dnešnej spoločnosti prináša mnoho nepredvídaných situácii, s ktorými sa musí jedinec vediet' vysporiadat'. Práve dostatočná úroveň tvorivého a kritického myslenia výrazne dopomáha čelit' explózii informácií a rôznym požiadavkám spoločnosti. Apelujúc na požiadavky modernej spoločnosti je žiadaný nový prístup učitel'ov k vzdelávaniu. Učitelia si v budúcnosti nevystačia s centrálne spracovanými vzdelávacími obsahmi a tradičnými vyučovacími metódami. Z tohto dôvodu je nevyhnutné, aby sa učitelia $s$ novými metódami postupne systematicky zoznamovali a naučili sa ich bežne používat'. Vo vzt'ahu k potrebe inovovat' edukačný proces a prispôsobovat' ho potrebám žiakom sa javí ako jedno z možných riešení využívat' aktivizujúce metódy, ktoré podporujú aktivitu žiakov vo vyučovaní a pomáhajú rozvíjat' tvorivé a kritické myslenie. Opodstatnenost' učenia aktivizujúcimi metódami vychádza zo skutočnosti, že to, čo človek sám prežil, cítil, videl, zostáva zakotvené hlboko v jeho vedomí, preto tento typ učenia treba rozvíjat' už od skorých rokov diet’at'a (Carbogim et. al. 2019; Kusumuto, 2018). Aktivizujúce metódy majú aj svoje prekážky vzt'ahujúce sa k časovej náročnosti prípravy danej metódy, ako aj samotnej realizácie a organizácii. Košt'álová et al. (2010) d’alej radia medzi prekážku 
spoluprácu v skupinách alebo v tíme. Uvádzajú, že približne $20 \%$ žiakov tomuto prístupu nerozumie alebo im to nedáva zmysel. Príčiny môžu byt' rôzne: niektorí žiaci nemusia byt' pripravení na konfrontáciu s ostatnými členmi alebo prijat' ich spätnú väzbu. Ďalším limitujúcim faktorom používania týchto metód je funkčné používanie písania a čítania žiakov. Iným faktorom môže byt' intelektuálna a sociálna úroveň žiakov (Petlák, 2019), ktoré taktiež môžu limitovat' používanie spomínaných metód. V rámci príspevku sme sa zamerali na teoretickú charakteristiku metódy: brainstorming, pojmového mapovania a problémového vyučovania. Prostredníctvom analýzy odborných publikácií sme poukázali na ich význam a vhodnost' využitia v procese rozvíjania tvorivého a kritického myslenia. Charakter a jednotlivé parametre vybraných metód sú síce odlišné, ale to nemení ich dôležitost' v procese rozvoja tvorivého a kritického myslenia. Vyššie uvedené metódy sú založené na princípe získavania nových vedomostí aktívnym spôsobom a na implementácií nových informácií do širšieho kontextu a vnútorného poznatkového systému, pričom sa využíva zapájanie oboch mozgových hemisfér, a zároveň sa podnecuje využívanie vyšších myšlienkových operácií. Na základe týchto faktov sa potvrdzuje ich význam pri rozvoji tvorivého a kritického myslenia v procese učenia.

\section{Pod'akovanie}

Príspevok je súčast'ou riešenia projektu UGA č. V/16/2020 pod názvom Analýza metód a stratégií rozvíjajúcich tvorivé a kritické myslenie žiakov.

\section{Literatúra}

AKINOGLU, O., TANDOGAN, R. O. (2007). The effect of problem - based aktive learning in science education on students' academic achievement, attitudie and koncept learning. Eurasia Journal of Mathematics, Science \& Technology Education. 3 (1), 71-81.

ALMUTAIRI, A. N. M., (2015). The Effect of Using Brainstorming Strategy in Developing Creative Problem Solving Skills among male Students in Kuwait: A Field Study on Saud Al-Kharji School in Kuwait City. Journal of Education and Practice. 6(3), 136-145. Dostupné na https://files.eric.ed.gov/fulltext/EJ1083780.pdf

BAGALOVÁ, L'. a kol. (2015). Metodika podporujúca inkluzívne vzdelávanie v školách. Bratislava: ŠPU. Dostupné na https://www.statpedu.sk/files/articles/nove_dokumenty/projekty/eea_grants/metodikapodporujuca-inkluzivne-vzdelavanie-skolach.pdf

BARRETT, T. (2017). A new model of problem based learning. Ireland: Aishe.

BARRETT, T. (2008). Students' talk about problem-based learning in liminal spaces. Unpublished PhD thesis, Coventry University. UK.

BORISOVÁ, S., ŠUTOVCOVÁ, L. (2019). Edukačné prostredie rozvíjajúce kritické a tvorivé myslenie. MMK 2019: recenzovaný sborník př́spěvků mezinárodní vědecké konference Mezinárodní Masarykova konference pro doktorandy a mladé vědecké pracovníky, 10(1) 863-870.

BRIDGES, E. M. (1992). Problem-Based Learning for Administrators. Washington: ED. Dostupné na https://files.eric.ed.gov/fulltext/ED347617.pdf

BROGGY, J., McCLELLAND, G. (2008). An investigation to determine the impact of concept mapping on learning in an undergraduate physics course. New Directions in the Teaching of Physical Sciences. (4), 34-38. Dostupné na https://journals.le.ac.uk/ojs1/index.php/new-directions/article/view/393/397 BUZAN, T. (2014). Mentální mapování. Praha: Portál.

CARBOGIM, F. C. et al. 2019. Active teaching model to promote critical thinking. Revista Brasileira de Enfermagem. 72(1), 293-298. Dostupné na https://www.scielo.br/pdf/reben/v72n1/0034-7167-reben-72-01-0293.pdf

ČINKA, L. 2012. Ovládněte svưj mozek. Brno: BizBooks.

DOULÍK, P., ŠKODA, J. (2011). Psychodidaktika. Bratislava: Grada. 
DRAPEAU, P. (2014). Sparking student creativity: Practical ways to promote innovative thinking and problem solving. Alexandria: ASGD.

DUCHOVIČOVÁ, J., GUNIŠOVÁ, D. (2015). Štrukturovanie učiva učitelom a konceptualizácia poznatkov žiakov. PegasJournal. 4(1), 33-49. Dostupné na http://www.pegasjournal.eu/files/Pegas1_2015_3.pdf

DUCHOVIČOVÁ, J., KOZÁROVÁ, N. (2016). Responsibility and Task Structuring as the Basic Attributes of Learning Styles and Their Relation Towards Consistency and the Quality of Hierarchy of a Learner's Mind Map. Acta Technologica Dubnicae. 6(2), 29-42. FISHER, R. (2004). Učíme děti myslet a učit se. Praha: Portál.

GRECMANOVÁ, H. et al. (2000). Podporujeme aktivní myšlení a samostatné učení žáků. 1. vyd. Olomouc: Hanex.

GUNIŠOVÁ, D., KOZÁROVÁ, N. (2016). Pojmové mapy v teórii a praxi. Nitra: UKF. HAJROVÁ, M. (2015). Rozvoj kritického myslenia metódami aktívneho vyučovania. MPC: Bratislava.

HARAUSOVÁ, H. (2011). Ako aktivizujúco vyučovat'odborné predmety. Bratislava: MPC. HOLLINGWORTH, R., MCLOUGHLIN, C. (2001). Developing science students' metacognitive skillsonline. Australian Journal of Educational Technology. 17(1), 50-63. Dostupné na https://www.ejmste.com/download/the-effects-of-problem-basedactivelearning-in-scienceeducation-on-students-academicachievement-4048.pdf

HOSAM, A., HURMUZAN, S. (2018). A review of brainstorming techniques in higher education. Thinking Skills and Creativity. 27, 78-91. Dostupné na https://www.sciencedirect.com/science/article/pii/S1871187117302729?casa_token=T5 QwuXzJOI0AAAAA:G1YaVZw1wRd_38t36Yaje_sIA6td3Oisy3M3iHgVqAKp4H1uS5JN c1RdvKvBSeEW9DXYZr0-tA

CHUKWUEMAKA, U. E., (2017). Effect of brainstorming startegy in developing creative problem sloving skills among primary school pupils in mathematics. International Technology Research Journal. 5(1), 91-102 Dostupné na https://www.journals.aphriapub.com/index.php/INTERJ/article/view/221/207

KAROLČíK, Š., MURTINOVÁ, L. (2013). Úspešnost' zaradenia pojmových máp do programu výučby geografie na nižšom stupni sekundárneho vzdelávania. Moderní vyučovaní. Dostupné na https://www.modernivyucovani.cz/uspenos-zaradeniapojmovych-map-do-programu-vyuby-geografie-na-niom-stupni-sekundarneho-

vzdelavania/

KENDLER, B. S., GROVE, P. A. (2004). Problem-Based Learning in the Biology Curriculum. The American Biology Teacher. 66 (5), 348-354.

KHODADADY, E. (2011). Brainstorming and Its Effect on Critical Thinking and SpeakingSkills. The Iranian EFL Journal. 2011. 7(1), 51-66. Dostupné na https://www.academia.edu/12896182/Brainstorming_and_Its_Effect_on_Critical_Thinki ng_and_Speaking_Skills

KICOVĀ, K. (2015). Alternatívne prístupy k pedagogickému hodnoteniu vo vyučovacom

procese. Edukácia. 1(2), 115-124. Dostupné na

https://www.upjs.sk/public/media/11267/15.pdf

KLOOSTER, D. (2000). Co je kritické myšlení? Kritické listy, 1 (2), 8-9.

KOŠŤÁLOVÁ, H. et al. (2010). Vybrané kapitoly pro rozvoj pedagogických dovedností. Praha: Oeconomica.

KOTRBA, T., LACINA, L. (2007). Praktické využití aktivizačních metod ve výuce. Brno: Barrister \& Principal.

KOTRBA, T., LACINA, L. (2015). Aktivizační metody ve výuce. Brno: Barrister \& Principal.

KOSTURKOVÁ, M. (2016). Rozvoj kritického myslenia žiakov stredných škôl. Prešov: Prešovská univerzita v Prešove. 
KOZÁROVÁ, N., GUNIŠOVÁ, D. (2019). Možnosti rozvoja kritického myslenia s ohl'adom na individuálne preferencie učenia sa žiakov. Inovatívne trendy $v$ odborových didaktikách: Prepojenie teórie a praxe výučbových stratégii kritického a tvorivého myslenia. 35-39.

KUCHÁROVÁ, J. (2007). Pojmové mapovanie ako jedna z možností zefektívnenia vyučovania hudobnej výchovy. Technológia vzdelávania. 15 (8), 15-17.

KUSUMOTO, Y. (2018). Enhancing critical thinking through active learning. Journal of the European Confederation of Language Centres in Higher Education (CercleS). 8(1), 45-63.

LÁSZLÓ, K. OSVALDOVÁ, Z. (2014). Didaktika. Banská Bystrica: Belianum. MAŇÁK, J., ŠVEC, V. (2003). Výukové metody. Brno: Paido

MARANGOS, J., ALLEY, S. (2007). Effectiveness of concept maps in economics: Evidence from Australia and USA. Learning and Individual Differences. 17(2), 193-199. MICHEL, N. et al. (2009). Active Versus Passive Teaching Styles: An Empirical Study of Student Learning Outcomes. Human resource development quarterly, 20(4), 397-418. MICHINOV, N. et al. (2015). The eyes of creativity: Impact of social comparison and individual creativity on performance and attention to others' ideas during electronic brainstorming. Computers in Human Behavior. 42, 57-67. Dostupné na. https://www.scopus.com/record/display.uri?eid=2-s2.0-

84911469415\&origin=inward\&txGid=bfc31934bbb80d4f7b4881ff8833d9f4

MISTRÍK, E. (2014). Zmysel a možnosti rozvojového vzdelávania. Rozvojové vzdelávanie. Témy a metódy (6-34). Bratislava: Pontis.

NOVAK, J. D. (2004). Reflections on a Half - Century of Thinking in Science Education and Research: Implications from a Twelve - Year Longitudional Study of Childrens Learning. Canadian Journal of Science, Mathematics and Technology Education. 4(1), p.23-41.

NOVAK, J. D., CAÑAS, A. J. (2007). Theoretical Origins of Concept Maps, How to Construct Them, and Uses in Education. Reflecting Education. 3(1), 29-42. Dostupné na https://www.researchgate.net/publication/228761562_Theoretical_origins_of_concept_ maps_how_to_construct_them_and_uses_in_education

NOVAK, J. D., CAÑAS, $\bar{A}$. J. (2008). The Theory Underlying Concept Maps and How to Construct Them. Technical Report IHMC CmapTools 2006-01 Rev 01-2008, Florida Institute for Human and Machine Cognition. Dostupné $\mathrm{Na}$ http://cmap.ihmc.us/Publications/ResearchPapers/TheoryUnderlyingConceptMaps.pdf PETLÁK, E. (2019). Súčast' a perspektívny didaktiky. Inovatívne trendy v odborových didaktikách:Prepojenie teórie a praxe výučbových stratégií kritického a tvorivého myslenia. 12-19. Dostupné na https://www.pf.ukf.sk/images/docs/projekty/2017/pCCp/konferencie/2019/APVV\%20Zborn\%C3\%ADk\%202019.pdf

PETRASOVÁ, A. (2003). Využitie stratégie EUR ako prostriedku eliminácie funkčnej negramotnosti rómskych žiakov. Prešov: MPC.

PETRASOVÁ, A. (2008). Kriticky mysliaci učitel' - tvorca kvality školy. Prešov: MPC.

PETROVÁ, G., KOZÁROVÁ, N. (2015). Pojmové mapovanie v edukačnom procese. Pedagogické rozhl'ady. 24 (4), 16-18. Dostupné https://mpcedu.sk/sites/default/files/rozhlady-casopis/pedagogicke_rozhlady_2015_4.pdf

PRŮCHA, J., WALTEROVÁ, E., MAREŠ, J. (2008). Pedagogický slovník. Praha: Portál. REBICH, S., GAUTIER, C. (2005). Concept - mapping to Reveal Prior Knowledge and Conceptual Change in a Mock Summit Course on Global Climate Chance. Journal of Geoscience Education. 53(4) 355-365.

ROWAN, K. (2014). Glossary of Instructional Strategies. Dostupné na http://www.beesburg:com/edtools/glossary.html 
SCHLEE, R. P., HARICH, K. R. (2014). Teaching creativity to business students: How well are we doing? Journal of Education for Business. 89(3), 133-141. Dostupné na https://www.scopus.com/record/display.uri?eid=2-s2.0-

85006276042\&origin=inward\&txGid=fa19d3fdd67a562d6d308b41304cb566

SITNÁ, D. (2013). Metody aktivního vyučování. Praha: Portál.

STANČ́́KOVÁ, D. (2015). Myšlienková mapa ako výsledok činnosti žiakov na hodinách ekonomiky a práva. Žilina: MPC Dostupné na https://mpcedu.sk/sites/default/files/projekty/vystup/13_ops_stancikova_dagmar__myslienkova_mapa_ako_vysledok_cinnosti_ziakov_na_hodinach_ēénonomiky_a_prav a.pdf

SUNGUR, S., TEKKAYA, C. (2006). Effects of Problem-Based Learning and Traditional Instruction on Self-Regulated Learning. The Journal of Educational Research. 99(5), 307322.

TOMENGOVÁ, A. (2012). Aktívne učenie sa žiakov - stratégie a metódy. Bratislava: MPC.

TSAI, CHW-W., SHEN, P-D, LU, Y-J. (2015). The Effects of ProblemBased Learning with Flipped Classroom on Elementary Students' Computing Skills: A Case Study of the Production of Ebooks. International Journal of Information and Communication Technology Education. 11(2), 32-40.

TUREK, I. (2014). Didaktika. Bratislava: Wolters Kluwer.

VAŇKOVÁ, P. (2014). Pojmové mapy ve vzdělávání. Praha: Karlova univerzita.

ZORMANOVÁ, P. (2009). Metody a formy aktivní práce žáků v teorii a praxi. Brno: MU.

ŽÁČOK, L'., BERNÁT, M. (2016). Návrh a verifikácia problémového vyučovania v strednej odbornej škole. 8 (2), 134-150.

\section{Adresa autora}

\section{Mgr. Lenka Šutovcová}

Katedra pedagogiky, Pedagogická fakulta, UKF v Nitre

Dražovská cesta 4, 94974 Nitra

lenka.sutovcova@ukf.sk 


\title{
ADAPTAČNÉ ŤAŽKOSTI ZAČÍNAJÚCICH ŠKOLÁKOV V CENTRE DIAGNOSTICKEJ ČINNOSTI UČITEL'A
}

\section{THE ADAPTATION DIFFICULTIES OF BEGINNING PUPILS IN THE CENTER OF TEACHER'S DIAGNOSTICS ACTIVITIES}

\author{
Radka Teleková \\ Katedra pedagogiky, Pedagogická fakulta, UKF v Nitre
}

\begin{abstract}
:
The beginning of school attendance is characterized by a set of changes that relate to the physical environment, the social area conditioned by the new role of the pupil and classmate, the rules and requirements of formal education. Their presence affects the nature of the adaptation process, which may have different durations depending on the individual assumptions of the student and the occurrence of adaptation difficulties. The teacher is expected to orientate in the specifics of the adaptation process, his purposeful knowledge through diagnostic activities, revealing potential difficulties with the assumption of adequate intervention. The teacher recognizes the manifestation of difficulties and uses diagnostic activities to identify possible causes. Current education therefore includes the implementation of pedagogical diagnostics as part of a teacher's work in primary education. The aim of the article is to theoretically describe the current state of knowledge about the adaptation difficulties of beginning students in the context of the diagnostic activity of a primary school teacher. We also pay attention to selected methods of pedagogical diagnostics, the aim of which is to create a comprehensive picture of pupils at the beginning of schooling. The teacher has several ways to evaluate the student's adaptation. The starting point is sufficient teacher preparedness with a focus on the structural component of adaptation, adequacy and contribution of findings. Pupils are confronted with a number of differences associated with the period of adaptation, which supports his theoretical knowledge and practical support for students. The teacher's diagnostic activity can ensure the success of the adaptation process, resp. prevention and correction of adaptation difficulties of beginning students.
\end{abstract}

Key words:

pedagogical diagnostics, adaptation difficulties, teacher

\section{Úvod}

Začiatok školskej dochádzky predstavuje naplnenie dlhodobých očakávaní, s ktorými je spojené široké spektrum zmien (Trubíniová, V. 2007, Rosier, K. - McDonald, M. 2011). Ich zvládnutie vytvára zát’až pre začínajúceho školáka. Adaptácia na nové podmienky je náročná, prítomné sú t’ažkosti spôsobené príčinami vzt'ahujúcimi sa na individuálne charakteristiky diet’at’a (Monkeviciene, O. a kol. 2006; Slezáková, T. - Tirpáková, A. 2006; Homol'ová, T. 2015) alebo vplyv prostredí, v ktorých prebieha rozvoj jeho osobnosti (Boethel, M. 2004; Harvard Family Research Project, 2007; Birch, H. S. - Ladd, W. G. 1997) V odbornej literatúre viacerí autori uvádzajú existenciu adaptačných t’ažkostí, ktoré sa objavujú u žiakov na začiatku školskej dochádzky (Marko, J. 1971, Babajevova, T.I. 1990, Vilčinskaja, B. J. 2000, Perry, B. - Dockett, S. 2003, Burvyté, S. 2011). Teoretické 
východiská a výskumné zistenia sú impulzom pre poznávanie procesu adaptácie každého žiaka. Učitel' uskutočňuje diagnostickú činnost', ktorej predmetom sú tiež adaptačné t'ažkosti $v$ rámci ich prejavov a príčin. Súbor diagnostických metód mu umožňuje vhodne vybrat' za účelom získania komplexného obrazu o aktuálnom stave rozvoja začínajúceho školáka.

\section{Adaptačné t’ažkosti žiakov na začiatku školskej dochádzky}

Na začiatku školskej dochádzky sa žiak ocitá v nových situáciách. Primárne vzdelávanie očakáva uplatňovanie individuálnych schopností a zručností, ktoré umožnia žiakovi adekvátne reagovat' v rýchlo meniacich sa podmienkach. Fyzické a sociálne prostredie, kontakty s rovesníkmi a zameranie činností sú pre začínajúcich školákov odlišné. Žiak môže mat' problém s prijatím a zvládnutím existujúcich zmien, čo podmieňuje vznik adaptačných t'ažkostí.

Špecifické zmeny $v$ období adaptácie majú dopad na kvalitu adaptačného procesu. Podla S. Burvyté (2011) spôsob prispôsobovania sa žiaka na začiatku školskej dochádzky podmieňuje výber a uplatnenie adaptačných nástrojov v budúcnosti.

C. Longobardi (2019) približuje existujúce zmeny v obsahu činností začínajúcich školákov - prevaha študijných činností nad hrovými, nové školské povinnosti a vzt’ahy s dospelými aj rovesníkmi v triednom kolektíve.

Pre označenie adaptačných t'ažkostí sa v odbornej literatúre používa viacero definícií. Terminologicky sa stretávame s pojmami maladaptácia alebo maladjustácia, (Kopányiová, A. 2009). J. Marko (1971) približuje maladaptáciu ako absolútny alebo čiastočný rozpor, ktorý je prítomný medzi požiadavkami školy a predpokladmi detí. Pojem maladaptácia využíva aj O. Čačka (2009), ktorý ju d’alej chápe v dvoch rovinách - pasívna a aktívna forma. V Pedagogickom slovníku (2009) je maladaptácia charakterizovaná ako zlá, neúplná a neadekvátna adaptácia.

Vzhl'adom na existujúce teoretické východiská, adaptačné t'ažkosti chápeme ako nerovnovážny stav alebo nezhodovanie sa podmienok výchovno-vzdelávacieho procesu s možnost'ami a schopnost’ami začínajúcich školákov. Žiak prejavuje úsilie o úspešné adaptovanie sa v školskom prostredí, ale tento proces nie je individuálne vydarený. Následne sa objavuje pocit nadmernej zátaže a neprimeraného tlaku, čo podmieňuje vznik adaptačných t'ažkostí.

\section{Diagnostická činnost' učitel'a}

Spomínané teoretické východiská zdôrazňujú dôležitost' poznania adaptačného procesu začínajúceho školáka, individuálnej úrovne prispôsobenia sa novým podmienkam, identifikovanie signálov a prejavov adaptačných t’ažkostí s odhalením ich príčin. $\mathrm{Na}$ začiatku školskej dochádzky uskutočňuje učitel' vlastnú diagnostickú činnost', prostredníctvom ktorej získava spomínané informácie o žiakovi.

Práca učitel'a na primárnom stupni vzdelávania $v$ súčasnosti zahŕňa uskutočňovanie pedagogickej diagnostiky. Jej predmetom je diet’a mladšieho školského veku, ktoré je chápané ako komplexná osobnost', člen sociálnej skupiny a rodinného prostredia. Dôraz je kladený na poznanie sociálneho kontextu diet'at'a, čo B. Kasáčová a M. Cabanová (2011) konkretizujú ako detské predpoklady, záujmy, vlastnosti, predstavy o škole a obsahu učiva.

Pedagogická diagnostika je považovaná za vednú disciplínu, ktorá má vlastný predmet skúmania. Pre učitel'a sa stáva poznatkovým a skúsenostným východiskom v budovaní jeho diagnostickej kompetencie. Následne uskutočnená diagnostická činnost' v praxi je definovaná ako diagnostikovanie. (Gavora, P. 2010) Z. Syslová a J. Kratochvílová (2015) vidia ako jej súčast' profesijné zvládnutie čiastkových diagnostických činností s predpokladom spolupráce s odborníkmi pre dosiahnutie adekvátneho rozvoja diet'at'a. V zmysle vymedzenia pedagogickej diagnostiky na prahu vzdelávania zdôrazňujeme jej 
dôležité postavenie pre zabezpečenie úspešného adaptačného procesu, resp. prevenciu a korekciu adaptačných t’ažkostí žiaka na začiatku školskej dochádzky. T.Slezáková (2006) považuje diagnostickú činnost' učitel'a za východisko tvorby vyhovujúcich edukačných podmienok, ktoré zodpovedajú charakteristike jednotlivých žiakov. Na prahu vzdelávania je špecificky žiadúce rešpektovat' schopnosti a možnosti každého diet'at'a. $\mathrm{Na}$ začiatku školskej dochádzky realizuje učitel' vstupnú diagnostiku prostredníctvom rôznych, vyhovujúcich spôsobov a metód. Závery diagnostickej činnosti by mali byt' následne uplatnené $v$ pedagogickej praxi ako podpora úspešnosti adaptácie žiaka, prekonanie a odstránenie individuálne prítomných adaptačných t’ažkostí žiaka. Pri vstupe do 1. ročníka základnej školy je sledovaná úroveň štartovacej spôsobilosti žiaka. Východiskovým materiálom sa stávajú pedagogické testy na posúdenie úrovne školskej pripravenosti, ktoré sú doplnené výsledkami pozorovania, portfóliom diet'at'a, diagnostickými informáciami, riešenými pracovnými listami a pod. Testovanie u nás sa využíva najmä v psychologickom kontexte, zväčša na základe odporúčania pedagógov. (Borbélyová, D. 2014, In: Borbélyová, D., Špernáková, B. 2014) Podl'a B. Špernákovej (2014, In: Borbélyová, D., Špernáková, B. 2014) je obsahom pedagogickej diagnostiky vo vymedzenom období gramotnost', úroveň vedomostí a vychovanosti, zvládnutie sebaobslužných činností a funkčnosti zmyslových orgánov, reč, motoriku, lateralitu a sociabilitu.

Posúdenie úrovne adaptácie žiaka, predchádzanie adaptačných t’ažkostí predpokladá výber adekvátnych diagnostických nástrojov. Ked'že ide najmä o analýzu možností a príčin individuálnych t’ažkostí v období adaptácie, tak je nevyhnutná spolupráca učitela so psychológom. Hlavným prvkom diagnostickej činnosti je posúdenie klúčových parametrov adaptácie, t. j. kognitívnych, sociálno-emocionálnych, fyziologických znakov. Diagnostická činnost' je orientovaná na identifikáciu t’ažkostí a následne určenie spôsobov pedagogickej intervencie, ktorá je uskutočňovaná prostredníctvom skupinových alebo individuálnych činností. Konzultácie sú určené žiakom s adaptačnými t’ažkost'ami, v triednom kolektíve ide o diskusie týkajúce sa rozvoja sociálnych zručností. V období adaptácie je nevyhnutnou súčast'ou aj práca s rodičmi, ktorí sú konfrontovaní s novou situáciou vyžadujúcou pedagogicko-psychologickú pripravenost'. Daná problematika je relevantná vzhl'adom na individuálne charakteristiky osobnosti diet'at'a, ktorého rozvoj prebieha $v$ diverzifikovanej súčasnosti. $V$ centre pozornosti je podpora smerom k začínajúcemu školákovi (Gladko, M. 2016).

\section{Metódy pedagogickej diagnostiky na začiatku školskej dochádzky}

V záujme rozvoja žiaka aplikuje učitel' v diagnostickej činnosti poznané teoretické základy pedagogickej diagnostiky. Učitel' vyberá vhodné metódy, ktoré mu umožnia poznat' aktuálny stav žiaka ako východisko d’alšej práce. V kontexte nášho príspevku, poznanie adaptačného procesu a existujúcich t’ažkostí každého žiaka na začiatku školskej dochádzky má dopad na kvalitu výchovno-vzdelávacieho procesu.

B. Kasáčová (2003) chápe diagnostické metódy ako zameranie sa na jedinca, skupinu, jav alebo proces. Aplikovanie diagnostických metód zodpovedá vymedzenému cielu a plánu, je sústavne a systematické. Uplatnením podnetov vyvolávajúcich správanie ide o odhalenie existujúcich väzieb určenej skutočnosti.

Jednou z najčastejšie využívaných diagnostických metód je pozorovanie, ktoré učitel' uskutočňuje viacerými spôsobmi. Jeho charakter umožňuje poznávat' žiaka v bežných podmienkach triedy, školy a rodiny. Z. Syslová a J. Kratochvílová (2018) upozorňujú na pozorovanie iba tých prejavov, ktoré môže učitel' vidiet', počut' a merat'. Autorky odporúčajú kombináciu pozorovania s inými metódami a spracovanie záznamu pozorovania, čím sa zvyšuje jeho prínos. V kontexte adaptačných t’ažkostí, pozorovanie je orientované najmä na ich prejavy, frekvenčný výskyt a intenzitu. 
Aspekty, ktoré nemožno zachytit' priamym pozorovaní, sú obsahom iných diagnostických metód. B. Kasáčová- M. Cabanová (2011) zdôrazňujú holistický charakter rozhovoru a upozorňujú na špecifiká diagnostického rozhovoru, ktorý má vymedzený ciel', naplánovaný postup kladenia otázok, ciel'avedomé podnecovanie k pokračovanie diskusie a smerovanie $\mathrm{k}$ dosiahnutiu ciel'a. $V$ praxi sú prítomné viaceré druhy rozhovoru, ktoré učitel' uskutočňuje podla jeho zámeru. V mladšom školskej veku má žiak sklon k realizácii hrových činností, v ktorých projektuje svoje správanie a aplikuje doterajšie vedomosti, skúsenosti, zručnosti. Pre učitela je hra vhodnou situáciou pre uskutočnenie diagnostických činností, ked'že umožňuje poznávat' prežívanie, úroveň osobnostného rozvoja, sebavyjadrenie a interakcie žiaka s rovesníkmi. Podobné diagnostické možnosti poskytuje aj kresba, či analýza produktov činnosti žiaka v súlade s ich špecifickými charakteristikami. Autorky (2011) spomínajú tiež používanie testov, ktoré umožňujú poznat' úroveň žiaka na začiatku školskej dochádzky. Pedagogické testy na posúdenie úrovne školskej pripravenosti sú používané za účelom zistenia východiskových spôsobilostí a vedomostí, ktoré sa stanú predpokladom plánovania edukačných činností a individualizácie vyučovania.

$\mathrm{Na}$ začiatku školskej dochádzky sú pre učitel'ku primárneho vzdelávania cenné informácie o predchádzajúcom rozvoji diet’at'a. V praxi sa pre ňu stávajú východiskom plánovania a uskutočňovania primeraných činností. Vhodným zdrojom je diagnostické portfólio žiaka z predprimárneho vzdelávania. Podla J. Kratochvílovej (2018) ide o systematický súbor prác diet'at'a, ktoré boli zhromaždené za určené časové obdobie. Jeho obsahom sú komplexné informácie o vývoji, pokrokoch a výsledkoch diet'at'a, s ktorými narába diet’a, učitel', rodičov alebo iní odborníci. Portfólio je východiskom analýzy pokrokov diet'at'a $v$ čiastkových oblastiach jeho rozvoja. Vychádzajúc z uskutočneného akčného výskumu, portfólio predstavuje hodnotný materiál k diagnostickej činnosti, ktorá je založená na dôkazoch.

Pri výbere diagnostického nástroja je potrebné vychádzat' zo štruktúry školskej adaptácie, ktorá zahŕňa fyziologické, psychologické, sociálne a vzdelávacie, resp. motivačné aspekty. Každý z nich sa vyznačuje vlastnými kritériami, ukazovatel'mi a priebehom. K ich poznávaniu môže učitel' využit' viacero metód, resp. konkrétnych nástrojov. Špecificky pre žiakov 1. ročníka bol N. Luskanovou zostavený dotazník zameraný na zistenie dynamiky školskej motivácie, ktorej nízka úroveň vypovedá tiež o t’ažkostiach v období adaptácie. Dotazník bol spracovaný a overovaný v Rusku, môže byt' aplikovaný individuálne alebo skupinovo. Vzhl'adom na vekovú skupinu sa realizuje ako štruktúrovaný rozhovor, t. j. obsah je čítaný výskumníkom, ktorý zaznamenáva odpovede žiaka. V dotazníku je desat' položiek s výberom možností odpovede. Následne je uskutočnené vyhodnotenie prostredníctva priradenia bodov podla klúča. Výsledkom je určenie školskej motivácie žiaka v rozsahu piatich úrovní (Rumjanceva, L. N. 2012). V edukácii je pozornost' učitel'a orientovaná na poznávanie začínajúcich školákov, čo uskutočňuje vlastnou diagnostickou činnost'ou. Metódy pedagogickej diagnostiky dokážu efektívne slúžit' zisteniu charakteru adaptačného procesu každého žiaka, odhalenia adaptačných t'ažkostí. Učitel' má k dispozícií široké spektrum spôsobov pre rozpoznanie t’ažkostí jednotlivca, čo sa stáva východiskom adekvátnej intervencie smerujúc k ich zmierneniu a odstráneniu. Podstatu vidíme $v$ uskutočňovaní celostnej diagnostiky zameranej na prejavy školskej maladaptácie. Systémový prístup k riešeniu danej oblasti vyžaduje spoluprácu odborníkov (učitel'ov, psychológov, špeciálnych pedagógov, pediatrov a pod.), rodičov budúcich žiakov a detí.

\section{Záver}

Začiatok školskej dochádzky sprítomňuje očakávané zmeny, s ktorými sa žiak nedokáže vždy bezproblémovo a samostatne vyrovnat'. Problematika adaptačných t'ažkostí konkretizuje potrebu zistenia ich súčasných príčin a prejavov, čo priamo nabáda 
k uskutočneniu diagnostikovania a prevencie raných prejavov. Diagnostická činnost' na začiatku školskej dochádzky predpokladá získanie komplexného pohl'adu na osobnost' žiaka. $\vee$ praxi sa zároveň stáva východiskom zabezpečenia úspešného procesu adaptácie, resp. prevencie alebo korekcie adaptačných t’ažkostí začínajúceho školáka. V závere môžeme konštatovat', že sme v predpokladom príspevku popísali súčasný stav poznania adaptačných t’ažkostí začínajúcich školákov. Danú problematiku sme uvádzali do kontextu s diagnostickou činnost'ou učitel'a primárneho vzdelávania, ktorý poznáva komplexnú osobnost' žiaka po nástupe do 1. ročníka základnej školy. Dominantnú pozornost' sme venovali konkretizácii možností diagnostickej činnosti učitel'a so zameraním na identifikovanie a poznávanie adaptačných t'ažkostí.

\section{Pod'akovanie}

Príspevok bol vypracovaný s podporou grantu.

Označenie grantu: V/17/2020 (UGA UKF v Nitre)

Názov grantu: Adaptačné t’ažkosti žiakov na začiatku školskej dochádzky - ich príčiny a prejavy

\section{Literatúra}

Birch, H. S. \& Ladd, W. G. 1997. The Teacher-Child Relationship and Children's Early School Adjustment. In: Journal of School Psychology, 35 (1) 61-79,

Boethel, M. 2004. Readiness: School, Family and Community. Southwest Educational Development Laboratory. Dostupné

http://www.sedl.org/connections/resources/readiness-synthesis.pdf

Borbélyová, D. \& Špernáková, B. 2014. Testovanie školskej pripravenosti $\checkmark$ pedagogickom kontexte. Bratislava: Metodicko-pedagogické centrum. Dostupné na: https://mpc-edu.sk/sites/default/files/projekty/vystup/borbelyova_spernakova_3_0.pdf

Burvyté, S. 2011. Individual's resistance to social crises is acquired in childhood. Journal of Pedagogy and Psychology 4, 17 - 25 . Dostupné na file:///C:/Users/HP/Desktop/v10195-011-0041-6.pdf

Čačka, O. 2009. Psychologie duševního vývoje dětí a dospívajících s faktory optimalizace. Brno: Doplněk.

Gavora, P. 2010. Akí sú moji žiaci. Nitra: Enigma.

Gladko, M. 2016. Adaptatsiya pervoklassnikov k shkole: osobennosti, problemy adaptatsii, sposoby ikh preodoleniya. Dostupné na: https://pedsovet.su/ns/6370_adaptacia_pervoklassnikov_k_shkole

Harvard Family Research Project, 2007. Family Involvement in Elementary school children's education. No. 2, Dostupné na: https://eric.ed.gov/?id=ED495467

Homol'ová, T. 2015. Adaptácia a adaptačné problémy žiakov v prvom ročníku primárneho vzdelávania. Psichologičeskij vademecum : psichologo-pedagogičeskoje soprovoždenie obrazovatel'nogo processa v učreždenijach različnogo tipa. Vitebsk : VGU imeni P.M.Mašerova, 175 - 182.

Kasáčová, B. \& Cabanová, M. (2011). Pedagogická diagnostika. Teória a metódy diagnostikovania v elementárnej edukácii. Banská Bystrica: BELIANUM.

Kopányiová, A. 2009. Terciálna prevencia v školstve. Bratislava: Výskumný ústav detskej psychológie a patopsychológie,

http://web.saaic.sk/nrcg_new/doc/Zbornik/09_Kap-3.3.pdf

Dostupné

na

Kratochvílová, J. 2018. Portfolio dítěte jako efektivní prostředek diagnostické činnosti učitelky v mateřske škole. In: Syslová, Z. \& Kratochvílová, J. \&Fikarová, T. 2018. Pedagogická diagnostika v MŠ. Práca s portfoliem dítěte.(s.29-59) Praha: Portál.

Longobardi, C. a kol. (2019). Students'psychological adjustment in normative school transition from kindergarten to high school: Investigating the role of teacher-student relationship quality.

Front.Psychol.10,

Dostupné

na 
https://www.ncbi.nlm.nih.gov/pmc/articles/PMC6548872/?fbclid=IwAR3PRpLUGeaJvol2 w1JseS84_c466zABi5tdPC9XBk7b1FvYASQ5vW6QsII\#ref51

Marko, J. 1971. Vpravovanie sa diet'at'a do školského prostredia. Bratislava: SPN Monkeviciene, O. \& Mishara, L. B. \& Dufour, S. 2006. Effects of the Zippy's Friends Programme on Children's Coping Abilities During the Transition from Kindergarten to Elementary School. IEarly Childhood Education Journal, 2006, 34 (1)

Perry, B. \& Dockett, S. 2003. Starting school: perspectives of Australian children, parents and educators. Edinburg: The British Education Research Association Annual Conference. Dostupné na: http://www.leeds.ac.uk/educol/documents/00003324.htm

Průcha, J. \& Walterová, E. \& Mareš, J. (2009). Pedagogický slovník. Praha: Portál.

Rosier, K. \& McDonald, M. 2011. Promoting positive education and care transitions for children. Dostupné na: https://aifs.gov.au/cfca/publications/promoting-positiveeducation-and-care-transitions-children

Rumjanceva, L. N. (2012). Psychologo-pedagogičeskoje soprovoždenie adaptacionnovo perioda pervoklassnikov. Učebno-metodičeskoe posobenie. Južno-Sachalinszk: Izdatel'stvo achalinskij Gasudarstvennij Universitet

Slezáková, T. \& Tirpáková, A. (2006). Adaptácia diet’at’a na školu - Súčasné pohl'ady na pedagogickú teóriu a prax. Nitra: PF UKF v Nitre.

Syslová, Z. \& Kratochvílová, J. (2018). Metodika pre učitel'ov. Praktická príručka k diagnostickému nástroju Predict. Praha: Nakladatel'stvo Dr. Josef Raabe s.r.o.

Trubíniová, V. 2007. Predškolská pedagogika: terminologický a výkladový slovník. Ružomber: Katolícka univerzita

Vilčinskaja, T.P. (2000) . Psixhologičeskije problémy dezadaptacii detej mladšego škol'nogo vozrastu. Moskva: Prosvečšenije.

\section{Adresa autora}

\section{Mgr. Radka Teleková}

Katedra pedagogiky, Pedagogická fakulta, UKF v Nitre

Dražovská cesta 4, 94974 Nitra

radka.telekova@ukf.sk 


\title{
ŠPECIFIKÁ PRÁCE UČITEL'A V PROCESE ADAPTÁCIE ŽIAKOV NA ZAČIATKU ŠKOLSKEJ DOCHÁDZKY
}

\section{THE SPECIFICS OF THE TEACHER'S WORK IN THE PROCESS OF ADAPTATION OF PUPILS AT THE SCHOOL ATTENDANCE START}

\author{
Radka Teleková \\ Katedra pedagogiky, Pedagogická fakulta, UKF v Nitre
}

\begin{abstract}
:
Pupils attribute different characteristics to primary school teachers than to kindergarten teachers due to the different content of activities, the formality of the school environment, the level and form of contacts. In pedagogical practice, the specifics of a teacher's work with beginning pupils are present. Emphasis is placed on ensuring the success and quality of the adaptation process of each pupil. The teacher actively builds contact with pupils and parents, thereby increasing the individual success of adaptation. The aim of the article is to theoretically describe selected specifics of the teacher's work with pupils and cooperation with parents in the process of pupils'adaptation. The existing links between the family and school environment influence the pupil's adaptation at the beginning of schooling. The relationship and nature of the mutual interaction between the teacher and the beginning pupil has an impact on the success of the adaptation process, the presence of adaptation difficulties. The beginning of school attendance presupposes intensive contact of the teacher with the parents, who complement each other in terms of activity and ideology. The individual process of adaptation requires the attention of the teacher, who becomes a designer of conditions for successful transition from kindergarten to primary school.
\end{abstract}

\section{Key words:}

teacher, adaptation of pupils, school attendance start

\section{Úvod}

Začínajúci školák prichádza do nového prostredia školy, ktorá kladie na neho doteraz nepoznané požiadavky. Ich zvládnutie vyžaduje dostatočnú mieru úsilia zo strany žiaka, ktorý potrebuje adekvátnu podporu rodinného prostredia. Prispôsobenie sa novým podmienkam a vyplývajúcim zmenám predstavuje obdobie adaptácie, ktorého podoba je závislá na individuálnych charakteristikách žiaka. Ide o špecifické obdobie, ktoré predpokladá komplexné teoretické a praktické poznávanie v záujme zvyšovania úspešnosti procesu adaptácie každého žiaka. $V$ odbornej literatúre sa problematikou adaptácie zaoberajú mnohí autori, ktorí ju približujú z pohl'adu vlastného zamerania a skúmania (Dockett, S. \& Perry, M. 2001, Margetts, M. 2006, Slezáková, T. 2006, Burvyté, S. 2011, Fabian, H. 2012). Proces adaptácie kladie jedinečné požiadavky nielen smerom k žiakovi, ale podmieňuje prácu učitel'a na začiatku školskej dochádzky. Pravidelná interakcia učitel'a so žiakmi má dopad na úspešnost' adaptácie, ktorej podoba závisí tiež od spolupráce s rodičmi. K predkladanému príspevku sme teda formulovali nadväzujúci ciel': Teoreticky popísat' vybrané špecifiká práce učitel'a so žiakmi a spolupráce $s$ rodičmi pri adaptácii žiakov. Učitelia primárneho vzdelávania disponujú 
teoretickými poznatkami a praktickými skúsenost'ami, ktoré sú predpokladom rešpektovania individuálnych charakteristík žiakov $v$ procese adaptácie. $\mathrm{Na}$ začiatku školskej dochádzky sú v práci učitela prítomné špecifiká, ktoré vyplývajú z jedinečnosti daného procesu u každého začínajúceho školáka.

\section{Adaptácia žiakov na začiatku primárneho vzdelávania}

K dôležitým momentom $v$ živote diet’at’a patrí vstup do základnej školy, ktorý podmieňuje celkový vzt'ah ku škole a vzdelaniu, podnecuje pre školskú prácu a pôsobí na jeho úspešnost' a spokojnost' v škole. Obdobie adaptácie začínajúceho školáka zahŕňa prispôsobenie sa novej časovej štruktúre, sociálnemu statusu, očakávaniam a požiadavkám zo strany učitel'a aj rodičov. Vychádzajúc z potreby rešpektovania individuálnych predpokladov diet'at'a na vstup do školy, musíme v pedagogickej praxi očakávat' prítomnost' adaptačných t’ažkostí jednotlivcov v rôznych oblastiach.

Začiatok školskej dochádzky zahŕňa široké spektrum zmien a požiadaviek, s ktorými sa musí vyrovnat' žiak, rodinné a sociálne prostredie. Ide o dynamický a vyvíjajúci sa proces, ktorý je súčast'ou vzdelávania ako komplexná etapa orientovaná na akademické a sociálno-emocionálne prispôsobenia sa. Učitelia kladú osobitý dôraz na zabezpečenie úspešného vstupu do primárneho vzdelávania, pretože proces adaptácie žiaka má dlhodobé účinky na d’alšie vzdelávanie a formovanie osobnostných charakteristík. (Besi, M. \& Sakellariou, M. 2019)

Vymedzením pojmu adaptácia sa zaoberajú mnohé vedné oblasti, ktoré ho približujú z pohl'adu vlastného zamerania. Pre potreby pedagogiky sa uplatňuje multidisciplinárne chápanie zahŕňajúce tri aspekty. Sociálno - psychologický aspekt predstavuje všeobecné prispôsobenia sa jednotlivca podmienkam spoločnosti, ktoré v edukačnej praxi predstavujú požiadavky školy smerom k povinnej role žiaka. K hlavným ukazovatel'om patrí formovanie vhodného správania sa, nadväzovanie kontaktov s učitel'mi a spolužiakmi, vytváranie učebných návykov. Pedagogický aspekt je konkretizovaný úpravou školského prostredia a zohl'adnenia individuálnych osobitostí diet'at'a, čo predpokladá elimináciu a zníženie výskytu nepriaznivých vplyvov. Fyziologický aspekt odkazuje na poznanie zdravotného stavu diet'at'a, možnosti organizmu a rozdielnu úroveň jeho zát’aže. Medzi jednotlivými aspektmi existujú významné súvislosti a prepojenie. Nedostatky v ktoromkol'vek aspekte môžu viest' k emocionálnej nestabilite, nedostatočnému vôl'ovému úsiliu, nízkej úrovni kontaktov žiaka so spolužiakmi a učitel'om ako rešpektovanou autoritou. Prítomnost' podobných javov má dopad na akademickú neúspešnost', zhoršenie zdravotného stavu. (Slezáková, T. \& Tirpáková, A. 2006)

\section{Interakcia učitel'-žiak}

Začiatok školskej dochádzky kladie dôraz na zabezpečenie úspešnej adaptácie každého žiaka, čo podmieňuje charakter výchovno-vzdelávacieho procesu. Učitel' by mal vytvárat' podmienky, ktoré podporujú plynulý prechod do základnej školy. Vo svojej práci by mal zohl'adňovat' individuálnu úroveň predpokladov začínajúceho školáka, ktoré podmieňujú jednotlivé atribúty vyučovacieho procesu.

T. Slezáková (2006) zdôrazňuje pedagogický prístup orientovaný na žiaka, čo predstavuje zmenu postoja učitel'a k nemu. Autorka poukazuje na dôležitost' produktívnej činnosti, poznávania $v$ učebnej činnosti žiakov a rešpektovania ich potrieb. $V$ záujme znižovania zát'aže na žiaka v 1 . ročníku základnej školy, učitel' volí metódy a organizačné formy podobné predprimárnemu vzdelávaniu. Učitel' by mal venovat' pozornost' podobe učebného prostredia v triede, ktorej vzhl'ad by mal byt' primeraný, pre žiakov vhodne stimulujúci a otvorený s možnost'ou pohybovej aktivity. Východiskom tvorby vhodných podmienok pre každého žiaka je diagnostická činnost' učitel'a, ktorá poskytuje komplexný obraz o individuálnej úrovni žiaka. Nástrojom podpory a sebadôvery na začiatku 
školského vzdelávania je pre žiaka hodnotenie zo strany učitel'a, ktorý zohl'adňuje reálne prejavy žiaka vzhl'adom na požiadavky školy. Pozitívne hodnotenie má vplyv na prežívania žiaka, uspokojovanie potrieb bezpečia a istoty, sebavedomie, čo má priamy dopad na akademickú úspešnost' a charakter adaptácie.

Proces adaptácie zahŕňa tiež tvorbu psycho-sociálnych podmienok $v$ triede, čo je konkretizované formovaním vzt’ahu žiaka k učitel'ke a spolužiakom. Učitel'ka je dôležitá osoba, s ktorou je začínajúci školák v každodennej interakcii. Predpokladom úspešnej adaptácie je akceptácia učitel'ky vo výchovno-vzdelávacom procese a následne jej vnímanie ako rovnocenného partnera, sprievodcu vo vlastnom rozvoji.

Pozitívne vzt'ahy žiaka s učitel'kou majú vplyv na úspešnost' individuálneho procesu adaptácie. V školskom prostredí sa lepšie adaptovali žiaci, ktorí mali relatívne blízke, nekonfliktné a nezávislé vzt’ahy s učitel'kou. Charakter vzájomnej interakcie má dopad na výskyt adaptačných t'ažkostí. $V$ pedagogickej praxi je považovaný za príčinu slabšieho akademického výkonu, negatívnych postojov k škole, nízku úroveň zapojenia sa do školského života a sebadôveru. Z výskumných zistení S. H. Birch \& G. W. Ladd (1997) d’alej tiež vyplýva vplyv pohlavia začínajúcich školákov na kvalitu vzt'ahov s učitel'mi. Podl'a vyjadrení učitel'ov sú častejšie prítomné konfliktnejšie a negatívnejšie vzt’ahy s chlapcami. Učitelia spomínajú bližšie, pozitívnejšie interakcie v kontakte $s$ dievčatami. Spomínané zistenie zodpovedá výskumne potvrdeným (Jánošová, $P$. 2008) rozdielom adaptácie podla pohlavia začínajúcich školákov, pričom lepšiu zvládajú proces adaptácie dievčatá v porovnaní s chlapcami.

Úspešnost' adaptácie je determinovaná širokým súborom faktorov, ktoré sa vzt’ahujú na individuálne charakteristiky žiaka a prostredie jeho rozvoja, t. j. rodinné, predškolské, školské prostredie. Z pohl'adu jednotlivca je nevyhnutné poznanie všetkých stránok jeho osobnosti. Komplexný prístup konkretizuje osobnostné charakteristiky v rámci kognitívnej, sociálno-emocionálnej a fyzickej oblasti. Existujúce nároky školského vzdelávania na kognitívne procesy sú potenciálnym zdrojom zátaže, vzniku adaptačných t’ažkostí. K súvisiacim príčinám radí J. Tholtová (2017) nepozornost', oslabenie slovnej alebo pracovnej pamäte, narušenie exekutívnych funkcií, problematická analýze a syntéza informácií. Všeobecne teda ide o individuálnu úroveň psychickej zrelosti, inteligencie a kompetencie učit' sa (Monkeviciene, O. a kol. 2006). Podl'a J. Bednářovej \& V. Šmardovej (2012) je predispozíciou úspešnej adaptácie tiež úroveň socializačných zručností, emocionálna a sociálna vyspelost'. Posúdenie fyzickej oblasti je v kompetencii pediatra, príp. iného odborníka z oblasti medicíny, ktorý diagnostikuje prípadne oslabenia.

R. Quaglia a kol. (2013) vidia priamu súvislost' medzi kvalitou interakcie učitel'a so žiakmi a rozvojom jazykových schopností, sociálnych zručností aj prispôsobením sa školskému vzdelávaniu. Pozitívny vzájomný vzt'ah je predpokladom školského úspechu, ktorý zahŕňa vzdelávací, sociálny a behaviorálny rozmer.

Podl'a T. Slezákovej (2006) je východiskom práce učitel'a so začínajúcimi školákmi porozumenie jeho potrebám, poznanie osobitostí učenia žiakov na začiatku školskej dochádzky, rešpektovanie jedinečnosti procesu adaptácie v plánovaní výchovnovzdelávacieho procesu, vnímanie adaptačných t’ažkostí a poskytnutie adekvátnej pomoci žiakom, spolupráca s rodičmi a inštitúciami.

\section{Spolupráca učitel'a s rodičmi}

Vstup diet'at'a do 1. ročníka základnej školy vyžaduje podporu rodinného prostredia, ktoré participuje na úspešnosti procesu adaptácie začínajúceho školáka. Pomoc rodičov a širšie charakteristiky rodiny sa podielajú na školských výsledkoch žiaka, jeho prispôsobení sa požiadavkám a podmienkach školského vzdelávania. Rodič by mal byt' metodicky vedený zo strany učitela, čím sa zabezpečení vyššia efektivita domácej prípravy žiaka. 
Začiatok školskej dochádzky je významným míl'nikom v živote diet’at’a a jeho rodiny. Rodičia získavajú vyššiu individuálnu a spoločenskú hodnotu, ktorá je odrazom vážnejších povinností rodiča školáka. (Kurincová, V. 2009, In: Kurincová, V. \& Slezáková, T. 2009)

R. Giallo a kol. (2010) uskutočnili výskumnú štúdiu, ktorej výsledky poukazujú na zvýšenú participáciu rodičov po poskytnutí intervencie absolvovaním zostaveného školského prechodového programu pre rodičov. Podl'a autorov boli rodičmi pozitívne hodnotené najmä informácie o činnostiach na prípravu diet’at'a do školy, pomoci pre diet'a na rozvoj zručností, zvládnutí situácií súvisiacich so začiatkom školskej dochádzky, vrátane separačnej úzkosti, prispôsobení rodinných zvyklostí a domácej príprave, riešení domácich úloh.

V období adaptácie je potrebné poznat' dominantné ukazovatele rodinného prostredia, ktoré majú dopad na úspešnost' začiatku školskej dochádzky žiaka a potenciálny výskyt adaptačných t'ažkostí. V odbornej literatúre sú za hlavné determinanty považované prejavy záujmu rodiča o diet’a v očakávanej role školáka, podpora v rodinnom prostredí, kvalitatívna úroveň podmienok na domácu prípravu žiaka, celková klíma rodiny, úroveň kognitívnej stimulácie, pocit pohody a istoty v rodinnom prostredí (Harvard Family Research Project, 2007)

V kontexte adaptácie, by podla M. Franclovej (2013) mal učitel' zmysluplne iniciovat' spoluprácu s rodičmi. Jednotlivé jej formy by mali byt' ciel'avedome podnecované, uskutočňované podla dohodnutých pravidiel a poriadku pre dosiahnutiu spoločného záujmu oboch strán - úspešnost' adaptácie žiaka na začiatku školskej dochádzky. Pri vstupe do 1. ročníka základnej školy sú prítomné viaceré úskalia a t’ažkosti, ktoré vyžadujú komunikácia učitel'a s rodičmi. Učitel' vystupuje ako konzultant a poradca, ktorý má odborné poznatky a skúsenosti z pedagogickej praxe. Jeho úlohou je najmä posilnenie záujmu a snahy rodičov formovat' začínajúcim školákom podmienky pre zvládnutie školského vzdelávania. Prostredníctvom cielavedomej komunikácie a spolupráce existuje žiak $v$ dvoch komplementárnych prostrediach, ktoré zabezpečujú dostatok podpory pre úspešnost' procesu adaptácie.

\section{Záver}

Práca učitel'a so začínajúcimi školákmi ma špecifiká, ktoré vyplývajú z jedinečných charakteristík procesu adaptácie každého žiaka. Na začiatku školskej dochádzky považujeme za dôležité venovat' pozornost' kvalite vzt'ahov žiakov s učitel'mi a medzi žiakmi navzájom. Učitel' by mal prakticky uplatňovat' teoreticky známe charakteristiky adaptácie, ktorá ovplyvňuje školské vzdelávanie žiaka. Tvorba podmienok pre zvýšenie úspešnosti adaptácie vyžaduje dostatočnú spolupráca učitel'a s rodičmi, ktorí sa podiel'ajú na zabezpečení plynulého prechodu do 1. ročníka základnej školy. Spoločné úsilie rodinného a školského prostredia prospieva začínajúcim školákom, ktorí získavajú pocit istoty, dôvery a podpory pri zvládaní existujúcich zmien a celkovom prispôsobovaní sa požiadavkám školy.

\section{Pod'akovanie}

Príspevok bol vypracovaný s podporou grantu.

Označenie grantu: V/17/2020 (UGA UKF v Nitre)

Názov grantu: Adaptačné t'ažkosti žiakov na začiatku školskej dochádzky - ich príčiny a prejavy

\section{Literatúra}

Bednářová, J. \& Šmardová, V. 2015. Diagnostika dítěte předškolního věku: co by dítě mělo umět ve věku od 3 do 6 let. 2 . vydání. Brno: Edka 
Besi, M. \& Sakellariou, M. 2019. Transition to Primary School the Importance of Social Skills. In: SSRG International Journal of Humanities and Social Science ( SSRG - IJHSS ). 6(1), 33-36, Dostupné na: <file:///C:/Users/HP/Downloads/10.IJHSSV6I1P107_Sakellariouetal.2019.pdf>

Birch, H. S. \& Ladd, W. G. 1997. The Teacher-Child Relationship and Children's Early School Adjustment. Journal of School Psychology, 35(1), 61-79.Dostupné na: <file:///C:/Users/HP/Desktop/K\%20DP/pou\%C5\%BEi\%C5\%A5/The_teacherchild_relationship_and_child.pdf> Burvyté, S. 2011. Realisation of personal adaptation potential in childhood. In: Petrov, R. \& Sloka, B. \& Vaivads, J. (eds.). European Integration and Baltic Sea Region: Diversity and Perspectives. (605-619) Riga: The University of Latvia Press. Dostupné na: $<$ http://dspace.lu.Iv/dspace/bitstream/handle/7/2924/Conference_EIBSRS_.pdf?sequen ce=1\#page=605>

Dockett, S. \& Perry, M. 2001. Starting School: Effective Transitions. Early Childhood Research and Practice. 3(2). Dostupné na: file:///F:/k\%20DP/StartingSchool.pdf

Fabian, H. 2012. Children Starting School. A guide to successful transitions and transfers for teachers and assistants. New York: Routledge. Dostupné na: <https://books.google.sk/books?id=reGOAQAAQBAJ\&pg=PA1\&lpg=PA1\&dq=Children +Starting+School.+A+guide+to+successful+transitions+and+transfers+for+teachers+an $\mathrm{d}+$ assistants\&source=bl\&ots=17FzHx0OJS\&sig=ACfU3U3RK8KolE9VtLH-

IBAtJP5uAJ96Fg\&hl=sk\&sa=X\&ved=2ahUKEwiRo42Rv8LiAhUFY1AKHYmJCJYQ6AE wB3oECAgQAQ\#v=onepage\&q=Children $\% 20$ Starting $\% 20$ School. $\% 20 A \% 20$ guide $\% 20 t$ o\%20successful\%20transitions $\% 20$ and $\% 20$ transfers $\% 20$ for $\% 20$ teachers $\% 20$ and $\% 20 a$ ssistants\&f=false >

Franclová, M. 2013. Zahájení školní docházky. Praha: Grada Publishing.

Giallo, R. \& Treyvaund, K. \& Matthews, J. \& Kienhuis, M. 2010. Making the Transition to Primary School: An Evaluation of a Transition Program for Parents. Australian Journal of Educational \& Developmental Psychology,10, 1-17. Dostupné na: https://files.eric.ed.gov/fulltext/EJ885703.pdf

Harvard Family Research Project, 2007. Family Involvement in Elementary school children's education. No. 2, Dostupné na: https://eric.ed.gov/?id=ED495467

Jánošová, P. 2008.Dívčí a chlapecká identita. Vývoj a úskalí. Praha: Grada Publishing. Kurincová, V. 2009. Diet’a medzi rodinou a školou. In: Kurincová, V. - Slezáková, T. Žiak na začiatku školskej dochádzky. Edukačná podpora učitel'ov a rodičov. ( s. 81-147) Nitra: PF UKF v Nitre.

Margetts, M. 2006. "Teachers should explain what they mean": What new children need to know about starting school Kay Margetts Summary of paper presented at the EECERA

16th Annual Conference Reykjavik, Iceland, Dostupné na: file:///C:/Users/HP/Desktop/Programy-

$\% 20$ transition $\% 20$ to $\% 20$ school/Pou\%C5\%BEi\%C5\%A5/margetts_eecera_06.pdf

Monkeviciene, O. \& Mishara, L. B. \& Dufour, S. 2006. Effects of the Zippy's Friends Programme on Children's Coping Abilities During the Transition from Kindergarten to Elementary School. Early Childhood Education Journal, 34 (1)

Slezáková, T. \& Tirpáková, A. 2006. Adaptácia diet’at'a na školu - Súčasné pohl'ady na pedagogickú teóriu a prax. Nitra: PF UKF v Nitre.

Quaglia, R a kol. 2013. The Pupil-Teacher Relationship and Gender Differences in Primary School. The Open Psychology Journal, 2013, 6, 69-75. Dostupné na: https://openpsychologyjournal.com/contents/volumes/V6/TOPSYJ-6-69/TOPSYJ-6-

69.pdf

Tholtová, J. 2017. Máme doma prváka. Učitel'ské noviny. LXIV (IX), 34-37 


\section{Adresa autora}

\section{Mgr. Radka Teleková}

Katedra pedagogiky, Pedagogická fakulta, UKF v Nitre

Dražovská cesta 4, 94974 Nitra

radka.telekova@ukf.sk 


\title{
FONOLOGICKÉ KOMPETENCIE OSVOJOVANIA SI ANGLICKÉHO ZÁKLADNÝCH A STREDNÝCH V PROCESE SLOVENSKU - POHLAD UČIACEHO SA ŠKOLÁCH NA
}

\section{PHONOLOGICAL COMPETENCE IN THE PROCESS OF ENGLISH LANGUAGE ACQUISITION IN PRIMARY AND SECONDARY SCHOOLS IN SLOVAKIA - A LEARNER'S PERSPECTIVE}

\author{
Renáta Timková \\ Katedra anglistiky a amerikanistiky, Filozofická fakulta, UPJŠ v Košiciach
}

\begin{abstract}
:
The current period brings the need for innovation and changes in the usual didactic procedures in teaching practice in the field of teaching English as a foreign language. This places increased demands on the readiness of future English language teachers so that after graduation they can participate as effectively as possible in the teaching process and bring new knowledge to the teaching of English. The paper focuses on current issues and procedures in the field of training English language student teachers with regard to strengthening and developing phonological competencies. When designing the needs of teaching, compiling the content of subjects focused on the practice of phonological competencies of future teachers, we rely on the feedback of students. We have used a questionnaire to find out their opinions, procedures, suggestions, feelings and experience from their process of learning English from the point of view of learning English as a foreign language. We have been interested in the process of acquiring students' phonological competencies in a formal (school) environment and an informal (out-of-school) environment. These attitudes allow us to improve the student teachers training during their university studies. The paper provides a summary of research findings.
\end{abstract}

\section{Key words:}

phonological competences, second language acquisition, pronunciation, Slovak learners of English, student teachers

\section{Úvod}

Príprava budúcich učitel'ov anglického jazyka by mala odrážat' súčasné potreby a požiadavky kladené na kvalitnú odbornú pripravenost' učitel'ov na učitel'ské povolanie. Úlohou inštitúcie, ktorá je zodpovedná za prípravu budúcich učitel'ov, je sledovat' a „zachytávat' uvedené požiadavky nielen zo strany samotných učitel'ov na školách, ale aj žiakov. Názory žiakov nám následne pomáhajú zlepšovat' úroveň prípravy budúcich učitel'ov. Osvojenie si správnej výslovnosti v cudzom jazyku je vel'mi zložitá úloha (Kenworthy, 1987, s. 27), proces osvojovania si výslovnosti v cudzom jazyku si vyžaduje sústredené úsilie učiaceho sa, tak aby sa dosiahla zrozumitel'nost' v komunikácii. V centre našej štúdie je študent anglického jazyka ako cudzieho jazyka na Slovensku. 
Zaujímali nás názory a úvahy študentov o výučbe výslovnosti počas základného a stredoškolského vzdelávania, zameriavame sa tak na výučbu výslovnosti v škole, ako aj na jednotlivé neformálne stratégie a postupy študentov používané za účelom zlepšenia výslovnosti anglického jazyka. Myslíme si, že takéto prieskumy by sa mohli uskutočňovat' vo väčšej miere. Predkladaná štúdia prispieva do diskusie o výučbe a osvojovaní si výslovnosti anglického jazyka učiacimi sa na základných a stredných školách na Slovensku. Spätnú väzbu študentov považujeme za nástroj d'alšieho zlepšovania vzdelávania budúcich učitel'ov na našej univerzite so špeciálnym zameraním na výučbu výslovnosti a používanie vhodných vyučovacích metód na základných a stredných školách na nácvik uvedenej zručnosti. Názory študentov nám pomôžu lepšie pochopit', ako naši študenti vnímajú učenie sa správnej výslovnosti, či si myslia, že je dôležitá správna výslovnost', a ako im výučba výslovnosti v škole pomohla získat' sebadôveru a sebavedomie pri komunikácii $v$ anglickom jazyku.

\section{Dotazník ako hlavná metóda výskumu}

Hlavnou metódou nášho výskumu pre zistovanie názorov študentov bol dotazníkový prieskum, ktorý je jednou z najčastejšie používaných metód vo výskume, a zároveň je relevantnou metódou pre získavanie spätnej väzby od študentov v oblasti osvojovania si cudzieho jazyka. Pri konštrukcii obsahovej stránky dotazníka sme v prvom rade rozdelili dotazník do logicky nadväzujúcich tematických oblastí, následne boli vytvorené položky pre jednotlivé tematické oblasti. Dbali sme na primeranú dížku dotazníka, celkový čas na vyplnenie dotazníka nepresiahol 20 minút. Vzhl'adom na skutočnost', že dotazník bol distribuovaný $v$ papierovej podobe a študenti ho vyplńali $\vee$ prostredí univerzity, bola zabezpečená $100 \%$ návratnost' dotazníkov, môžeme konštatovat', že prieskum sa u študentov stretol s pochopením. Vzhl'adom na stupeň ovládania anglického jazyka u našich respondentov, sme sa rozhodli pre použitie práve tohto jazyka $v$ jednotlivých dotazníkových otázkach. $V$ prípade otvorených otázok si však respondenti mohli vybrat' jazyk odpovede (slovenský alebo anglický). V prevažnej miere boli odpovede napísané $\mathrm{v}$ anglickom jazyku. Dotazník bol zložený z úvodnej časti a následných piatich častí $(A, B, C, D, E)$. Úvodná čast' dotazníka pozostávala z demografických položiek, ktorých ciel'om bolo zistit' vek, typ ukončenej strednej školy a celkovú dížku štúdia anglického jazyka. Zároveň nás zaujímalo, či si respondenti anglický jazyk osvojovali len prostredníctvom hodín anglického jazyka na základnej a strednej škole alebo navštevovali zároveň jazykovú školu, príp. absolvovali individuálne hodiny anglického jazyka. V časti $A$ sme sa študentov pýtali na ich názory týkajúce sa dôležitosti osvojovania si výslovnosti v cudzom jazyku. Chceli sme vediet' či považujú zručnost' rozprávania a správnu výslovnost' v cudzom jazyku za dôležitú jazykovú kompetenciu. Zároveň nás zaujímalo, či študenti pocit'ujú potrebu d'alšieho nácviku a zdokonal'ovania výslovnosti anglického jazyka. Požiadali sme študentov o uvedenie konkrétnych oblastí výslovnosti, ktoré by si radi zlepšili, resp. v ktorých pocit'ujú rezervy a radi by si danú oblast' výslovnosti zlepšili. V časti A dotazníka sme na zistenie odpovedí použili otvorené položky a pät'stupňovú posudzovaciu slovnú škálu - Likertovu škálu, ktorá pozostávala zo stupnice „strongly disagree - disagree - neutral - agree - strongly agree" (úplne nesúhlasím - nesúhlasím - neutrálny - súhlasím - úplne súhlasím). V časti B sme sa pýtali na spôsoby neformálneho osvojovania si výslovnosti cudzieho jazyka v prostredí mimo vyučovacích hodín v škole. Použili sme opät' pät'stupňovú posudzovaciu slovnú škálu Likertovu škálu, ktorá pozostávala zo stupnice „never - hardly - sometimes - often always" (nikdy - takmer nie - niekedy - často - vždy). Čast' C dotazníka sme zamerali na samotný spôsob nácviku výslovnosti v prostredí školy na hodinách anglického jazyka. V tomto prípade sme použili zatvorené položky s viacnásobným výberom odpovedí, polouzavreté položky, otvorené položky a v jednej z otázok sme opät' zvolili pät'stupňovú posudzovaciu slovnú škálu - Likertovu škálu, ktorá pozostávala zo stupnice stupnice 
„never - hardly - sometimes - often - always“ (nikdy - takmer nie - niekedy - často vždy). Ciel'om časti D bolo zistit', do akej miery využívali študenti fonetický prepis (transkripciu) pri osvojovaní si výslovnosti v anglickom jazyku, Ked'že fonetický prepis sa považuje za dôležitú súčast' nácviku správnej výslovnosti. Opät' sme zvolili pät'stupňovú posudzovaciu slovnú škálu - Likertovu škálu, ktorá pozostávala zo stupnice „never hardly - sometimes - often - always" ( nikdy - takmer nie - niekedy - často - vždy) a zo stupnice "strongly disagree - disagree - neutral - agree - strongly agree“ (úplne nesúhlasím - nesúhlasím - neutrálny - súhlasím - úplne súhlasím). V poslednej časti $\mathrm{E}$ sme venovali pozornost' spôsobom opravy nesprávnej výslovnosti zo strany učitel'a na hodinách anglického jazyka a názorom študentov na dostatočný/nedostatočný nácvik výslovnosti v školskom prostredí. Opät' sme využili pät'stupňovú posudzovaciu škálu, otvorené a polouzavreté položky. Pre vyhodnotenie škálových položiek dotazníka sme použili percentuálne vyhodnotenie.

\section{Analýza výsledkov dotazníkového prieskumu: demografické položky} Našimi respondentmi boli študenti prvého ročníka britských a amerických štúdií na Filozofickej fakulte Univerzity Pavla Jozefa Šafárika. V centre záujmu boli študenti, ktorí absolvovali základné a stredné školy na Slovensku, ked’že naším ciel'om bolo zistit' postoje študentov, ktorí prešli vzdelávacím systémom na Slovensku. Napriek tomu, že o vyplnenie dotazníka sme požiadali aj zahraničných študentov (Ukrajina, Španielsko, Grécko), ich názory nie sú obsiahnuté v predkladanej analýze, ked'že náš primárny záujem sa dotýkal absolventov slovenských základných a stredných škôl. Ďalším dôvodom bol nižší počet vyplnených dotazníkov zo strany zahraničných študentov, ktorý by nám neposkytol relevantnú porovnávaciu vzorku $\mathrm{k}$ analyzovaným dotazníkom slovenských študentov. Dotazníkového prieskumu sa zúčastnilo spolu 82 študentov prvého ročníka bakalárskeho štúdia, ktorých úroveň ovládania anglického jazyka sa pohybuje na úrovni $C 1$ - C2 (podl'a Spoločného európskeho referenčného rámca pre jazyky). Z celkového počtu respondentov bolo 62 študentov absolventmi gymnázií, 13 študentov ukončilo stredoškolské vzdelanie na obchodných akadémiách a 5 študentov na stredných odborných školách. Väčšina z nich študovala na stredných školách vo východoslovenskom regióne: Košice (43 študentov), Prešov (6 študentov), Humenné (4 študenti), Michalovce (3 študenti), Spišská Nová Ves (3 študenti), Trebišov (3 študenti), Poprad (2 študenti), Bardejov (2 študenti), Sobrance (2 študenti), nasledujúce mestá sú zastúpené jedným respondentom: Číž, Revúca, Sabinov, Moldava n/Bodvou, Stará L'ubovňa, Tornal'a, Vranov n/Topl'ou, Sečovce, Svidník, Vel'ký Kamenec; d'alšie regióny Slovenska zastúpené jedným respondentom: Muránska Dlhá Lúka, llava a Banská Bystrica. Jeden respondent neuviedol mesto svojho stredoškolského vzdelania.

\section{Analýza výsledkov dotazníkového prieskumu: tematické oblasti}

Výsledky analýzy časti A dotazníka nás presvedčili o tom, že študenti považujú správnu výslovnost' anglického jazyka za vel'mi dôležitú súčast' úspešnej komunikácie v cudzom jazyku. 49\% opýtaných uviedlo, že s týmto tvrdením „úplne súhlasí“ 40\% uviedlo možnost' „súhlasím“, $11 \%$ respondentov zaujalo „neutrálny“ postoj. Zároveň sme študentom poskytli možnost' uviest' slovný komentár ku zvolenej odpovedi. Z tejto časti vyberáme nasledovné názory: „dobrá výslovnost' umožňuje študentom zvyknút' si na jazyk“, „je dôležité, ak chcete, aby vás rodení hovoriaci brali vážne“, „je to štýlové“, „dobrá výslovnost' nám pomáha porozumiet"“, , jazyk znie nádherne, ak sú jeho slová vyslovené správne“, „keby mal každý dobrú výslovnost', neexistovali by akcenty a bola by to škoda“. Častou otázkou, s ktorou sa učiaci sa stretávajú v súvislosti s osvojovaním si výslovnosti v cudzom jazyku, sa týka ich snahy osvojit' si výslovnost' na úrovni rodeného hovoriaceho, t. j. čo najviac sa priblížit' výslovnosti rodeného hovoriaceho, zniet' ako rodený hovoriaci. Získali sme podobné výsledky analýzy ako v prípade otázky týkajúcej 
sa dôležitosti ovládania správnej výslovnosti. Možnost' „úplne súhlasím“ uviedlo 49\% respondentov, 39\% „súhlasi“" 12\% opýtaných uviedlo, že k tejto snahe zaujíma „neutrálny“ postoj. V prieskume sme sa d'alej pýtali, či si študenti myslia, že sa vo výslovnosti anglického jazyka potrebujú d’alej zdokonal'ovat' (pripomíname, že našimi respondentmi boli študenti s jazykovou úrovňou C1 - C2, podla Spoločného európskeho referenčného rámca pre jazyky, t. j. skúsení používatelia jazyka). Napriek tomu $62 \%$ opýtaných „súhlasí" s tým, že ich výslovnost' sa potrebuje nad'alej zdokonal'ovat', 16\% s týmto názorom „úplne súhlasí“, 15\% respondentov zaujalo „neutrálny“ postoj a 7\% opýtaných s týmto tvrdením „nesúhlasí“. Najväčšie nedostatky pocit’ujú respondenti $\checkmark$ plynulosti ústneho prejavu v miere eliminácie akcentu v anglickom jazyku.

Čast' B dotazníka bola zameraná na spôsoby osvojovania si anglického jazyka učiacimi sa v neformálnom prostredí. Najdôležitejšie výsledky analýzy tejto časti dotazníka sú zachytené v Obr.1, z ktorého vyplýva, že najčastejšie využívanými podpornými zdrojmi pre zdokonalenie sa je pozeranie filmov, počúvanie hudby, diskusia s rodeným hovoriacim, internet, diskusia s priatel'mi a použivanie mobilných aplikácií. Respondenti mohli označit' viac než jednu možnost' podporného nácviku výslovnosti, výsledky však naznačujú, že osvojovanie si ústnej podoby anglického jazyka pomocou filmov a hudby zostáva tradičným a oblúbeným spôsobom zdokonal'ovania sa v cudzom jazyku. Očakávali sme vyššie zastúpenie používania mobilných aplikácií, študenti nám však v neformálnych rozhovoroch uviedli, že aj ked' niektorú z aplikácií na nácvik výslovnosti angličtiny (prípadne osvojovanie si anglického jazyka ako takého) vyskúšali, nezaujala ich do takej miery, že by ju opakovane využívali. Nebránili sa však využívaniu mobilných aplikácií v budúcnosti, pokial' budú svojím obsahom pre nich zaujímavé. V tejto téme vidíme priestor aj pri príprave budúcich učitel'ov angličtiny.

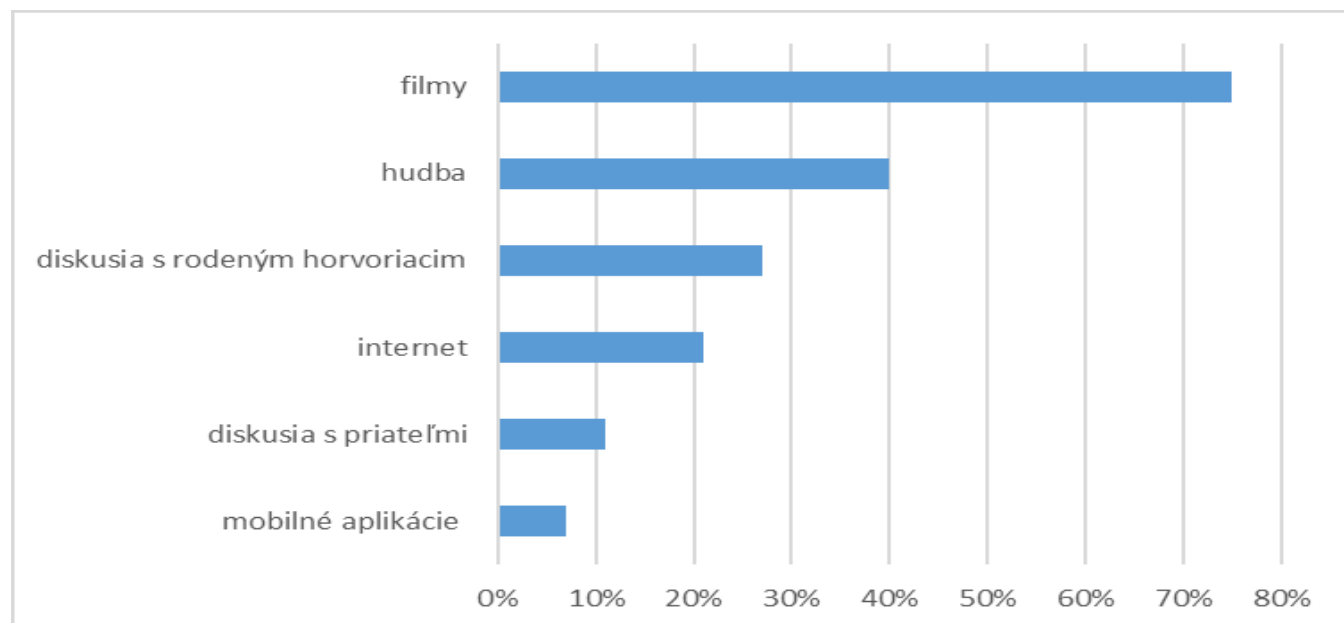

Obr. 1: Spôsoby osvojovania si anglického jazyka v neformálnom prostredí

V časti $C$ sme zist'ovali aké typy cvičení (aktivít) zamerané na osvojovanie si výslovnosti boli na hodinách anglického jazyka na školách využívané najčastejšie. Z výsledkov dotazníkového prieskumu vyplynulo, že najčastejšie používanými aktivitami sú: počúvaj, počúvaj a opakuj, čítaj nahlas, ktoré uviedlo $78 \%$ respondentov. Zároveň $70 \%$ študentov uviedlo, že na hodinách anglického jazyka pri nácviku výslovnosti najčastejšie využívali cvičenia v učebniciach.

Ked'že používanie transkripcie (fonetického prepisu) sa považuje za dôležitú súčast' nácviku výslovnosti predovšetkým novej slovnej zásoby, zaujímalo nás do akej miery sa 
transkripcia využíva vo vyučovaní angličtiny. Ukázalo sa však, že transkripciu využívalo pravidelne len $13 \%$ respondentov, ktorí uviedli že túto metódu využívali vždy (4\%) alebo vel'mi často $(9 \%)$.

V časti E nám výsledky analýzy dotazníka pomohli získat' predstavu o miere používania anglického jazyka učitel'om na hodinách anglického jazyka. 40\% respondentov uviedlo, že na hodinách učitel' vždy používal anglický jazyk, 50\% respondentov uviedlo, že učitel' používal anglický jazyk často (podrobné výsledky sú uvedené v Tab.1). Uvedené zistenia môžeme považovat' za uspokojivé, ked'že maximálna možná miera využívania anglického jazyka zo strany učitel'a zohráva dôležitú úlohu v procese osvojovania si cudzieho jazyka. Potešujúcim zistením je aj fakt, že žiaci a študenti vítajú, ked' učitel' opraví ich nesprávnu výslovnost'. S týmto názorom súhlasí $53 \%$ respondentov, úplne súhlasí $28 \%$ respondentov a $17 \%$ respondentov má neutrálny postoj (podrobné výsledky sú uvedené v Tab.1).

Tab. 1: Čast' E dotazníka - výsledky analýzy

\begin{tabular}{|l|l|lll|}
\hline $\begin{array}{l}\text { Likertova škála/ } \\
\text { otázky }\end{array}$ & $\begin{array}{l}\text { Uvítali ste, ak } \\
\text { učitel' } \\
\text { vašu výslovnost'? }\end{array}$ & $\begin{array}{l}\text { Myslíte si, že nácviku výslovnosti bol } \\
\text { venovaný dostatok času? }\end{array}$ \\
\hline úplne súhlasím & $28 \%$ & $3 \%$ & & \\
\hline súhlasím & $53 \%$ & $10 \%$ & & \\
\hline neutrálny & $17 \%$ & $30 \%$ & & \\
\hline nesúhlasím & $2 \%$ & $40 \%$ & & \\
\hline úplne nesúhlasím & $0 \%$ & $17 \%$ & \\
\hline $\begin{array}{l}\text { Likertova škála/ } \\
\text { otázky }\end{array}$ & $\begin{array}{l}\text { Opravoval učitel' } \\
\text { na hodinách vašu } \\
\text { výslovnost'? }\end{array}$ & $\begin{array}{l}\text { Rozpráva učitel' po anglicky na na nách anglického jazyka? } \\
\text { hodinál }\end{array}$ \\
\hline nikdy & $0 \%$ & $0 \%$ & & \\
\hline takmer nie & $8 \%$ & $2 \%$ & & \\
\hline niekedy & $27 \%$ & $8 \%$ & & \\
\hline často & $50 \%$ & $50 \%$ & & \\
\hline vždy & $15 \%$ & $40 \%$ & & \\
\hline
\end{tabular}

\section{Záver}

Zistenia dotazníkového prieskumu nás presviedčajú o tom, že výučba komunikačných kompetencií so zretel'om na fonologické kompetencie na základných a stredných školách si vyžaduje pozornost' nielen zo strany učitel'ov z praxe, ale zvýšenú pozornost' je potrebné aj nad'alej venovat' príprave budúcich učitel'ov počas štúdia na univerzite. $\checkmark$ rámci predmetov zameraných na osvojenie si fonologických kompetencií a zároveň predmetov zameraných na metodické prístupy k výučbe fonologických kompetencií je potrebné neustále hl'adat' inovatívne postupy, ktoré by pomohli budúcim učitel'om jazyka sebavedome zvládat' nácvik výslovnosti na hodinách anglického jazyka. Snaha aplikovat' výsledky komparatívnych výskumov fonologického systému slovenčiny a angličtiny predstavuje jednu z možností ako lepšie porozumiet' fungovaniu „zvukov“ angličtiny na pozadí slovenčiny. U učiacich sa prevláda túžba čo najviac sa priblížit' v ústnom prejave rodenému hovoriacemu, čo považujeme za legitímne očakávania pri učení sa cudzieho jazyka. Túto snahu je možné docielit' efektívnymi metódami zameranými na elimináciu nechceného „akcentu“ interferujúceho z materinského jazyka. Ciel'om učitel'a a budúceho učitel'a jazykov je „ukázat" a nasmerovat' učiacich sa tak, aby v prvom rade zvládali komunikačné jazykové situácie s prehl'adom, porozumeli ústnemu prejavu $v$ anglickom jazyku a zároveň zvládali ústny prejav sebavedome a isto. Je to náročná úloha, ktorá si vyžaduje sústavnú pozornost' učitel'ov anglického jazyka, ale zároveň je 
potrebné poznat' a podchytávat' spätnú väzbu práve od žiakov a študentov, ktorá pomáha učitel'om, budúcim učitel'om a odborníkom posúvat' a skvalitňovat' metodické postupy reflektujúc potreby a motivácie učiaceho sa.

\section{Literatúra}

Benzies, Y. J. C. (2013). Spanish EFL University Students' Views on the Teaching of Pronunciation: A Survey-Based Study. In: Language Studies Working Papers University of Reading, C. Ciarlo and D. S. Giannoni (eds.), vol. 5, p. $41-49$.

Chongning, Ch. (2009). Students Feedback to their Pronunciation Learning. Teaching English in China -CELEA Journal, vol. 32, no. 5, p. 38 - 49.

Kenworthy, J. (1987). Teaching English Pronunciation. Longman.

Waniek-Klimczak, E., Klimczak, K. (2005). Target in Speech Development: Learners' Views. In: K. Dziubalska-Kołaczyk, J. Przedlacka (eds.). English Pronunciation Models: A Changing Scene. Peter Lang, p. 229-249.

Spoločný európsky referenčný rámec pre jazyky: učenie sa, vyučovanie, hodnotenie. (2007). Štátny pedagogický ústav, Bratislava.

Szyszka, M. (2015). Good English Pronunciation Users and their Pronunciation Learning Strategies. Research in Language, vol. 13:1, p. 93 - 106.

Tergujeff, E. (2013). Learner Perspective on English Pronunciation Teaching in an EFL Context. In: Research in Language, vol. 11.1, p. 81 - 95.

\section{Adresa autora}

Doc. Mgr. Renáta Timková, PhD.

Katedra anglistiky a amerikanistiky, Filozofická fakulta, UPJŠ v Košiciach Moyzesova 9, 04001 Košice renata.timkova@upjs.sk 


\title{
ŠPECIFIKÁ VÝUČBY SLOVENČINY AKO CUDZIEHO JAZYKA Z POHLADU PEDAGÓGA
}

\section{SPECIFICS OF TEACHING SLOVAK AS A FOREIGN LANGUAGE FROM THE TEACHER'S PERSPECTIVE}

\author{
Renáta Timková
}

Katedra anglistiky a amerikanistiky, Filozofická fakulta, UPJŠ v Košiciach

\begin{abstract}
:
The teaching of Slovak as a foreign language has a long tradition at the Faculty of Medicine of Pavol Jozef Šafárik University in Košice. Language acquisition of Slovak as a foreign language is also a natural part of the education of foreign students of the Faculty of Medicine. The paper summarizes some basic specifics observed mainly in the use of mediation language in lessons of Slovak as a foreign language for beginners with regard to students from non-Slavic environments, in teaching specific Slovak language for beginners and in using authentic language in medical Slovak in preparing students for communication with the patient. The teaching of Slovak as a foreign language has its specifics which need to be thoroughly acquainted with the training of a teacher of Slovak as a foreign language in order to get acquainted with them and to bring solutions that will help more effective acquisition of Slovak by foreign students. For the teacher, the teaching practice and experience gained in everyday work with foreign students in Slovak language classes brings invaluable solutions.
\end{abstract}

Key words:

teaching Slovak language as a foreign language, mediation language, medical Slovak, language education

\section{Úvod}

V súčasnosti sa $v$ univerzitnom prostredí čoraz častejšie stretávame $s$ výučbou slovenčiny pre zahraničných študentov. Súvisí to s otvorením sa slovenského univerzitného prostredia pre záujemcov o štúdium zo zahraničia, snahou slovenských univerzít otvorit' sa svetu, s narastajúcim 'kreditom' slovenských univerzít, ktorý motivuje zahraničných potenciálnych študentov o uchádzanie sa o štúdium na našich univerzitách. Vysokoškolské vzdelávanie tak nadobúda medzinárodný rozmer, proces internacionalizácie sa stáva samozrejmost'ou. Napriek tomu však častokrát, pri zabezpečovaní vzdelávacieho procesu, rozlišujeme medzi výučbou určenou pre zahraničného študenta a domáceho študenta. Čo máme vlastne na mysli a prečo je nutné rozlišovat' medzi výučbou domáceho a zahraničného študenta? Najdôležitejšie faktory spočívajú predovšetkým v jazyku výučby a v potrebe zohl'adnenia kultúrnych aspektov $v$ prístupe $k$ zahraničnému študentovi najmä $v$ úvodnom období štúdia. V snahe ul'ahčit' zahraničnému študentovi adaptáciu na slovenské akademické prostredie a život na Slovensku, ponúkajú častokrát univerzity predmet slovenský jazyk ako cudzí jazyk. Uvedený predmet tak slúži ako platforma nielen pre osvojenie si jazyka, ale aj oboznámenie sa s kultúrou krajiny. V našom príspevku sa zameriame predovšetkým na predmety slovenského jazyka ponúkané na nefilologických fakultách, nakol'ko výučba slovenčiny ako cudzieho jazyka na nefilologických fakultách slovenských 
univerzít sa $v$ posledných rokoch dostáva čoraz viac do popredia. Ich jazykové kompetencie sú prakticky nulové a v rámci 2-3 ročného cudzojazyčného vzdelávania sa postupne dostávajú na úroveň A2 - B1 (podl'a Spoločného európskeho referenčného rámca pre jazyky). Osvojujú si základy všeobecnej slovenčiny a postupne zvládajú aj cielene vybrané oblasti praktického odborného slovenského jazyka.

\section{Mediačný jazyk}

Ako už bolo spomenuté v úvode článku, zahraniční študenti medicíny prichádzajú do prvého ročníka (ale aj do vyšších ročníkov štúdia po tzv. transfere z iných univerzít zo zahraničia) s nulovou znalost'ou slovenského jazyka, ktorý je však súčast'ou študijného programu už v prvom semestri prvého ročníka, v prípade 'transferových' študentov v semestri po nástupe na štúdium na Lekársku fakultu UPJŠ. Vynára sa teda otázka vzájomného dorozumievacieho prostriedku na hodinách slovenčiny ako cudzieho jazyka, ked'že zahraničný študent neovláda ani základy slovenčiny a učitel' neovláda jazyk, ktorým zahraničný študent rozpráva, a vzhl'adom na vysoký počet zahraničných študentov je jazyková diverzita vyššia, študenti pochádzajú z rôznych krajín sveta. Je preto nutné zvolit' si tzv. mediačný jazyk, ktorý bude v procese výučby používaný. Stretávame sa s dvomi rôznymi metodickými prístupmi. Jeden z prístupov má za ciel' používanie výlučne slovenského jazyka už od začiatočníckej úrovne, tak aby bol učiaci sa čo najviac vystavený osvojovanému jazyku od prvého momentu výučby. Ďalší z prístupov pripúšt'a využívanie iného jazyka ako mediačného jazyka, v našom prípade anglického jazyka na hodinách slovenčiny ako cudzieho jazyka. Podotýkame, že obidva prístupy sú plnohodnotné a záleží na vyučujúcom, ktorý z prístupov si zvolí. Naša skúsenost' z dlhoročnej praxe výučby slovenčiny ako cudzieho jazyka sa prikláňa k názoru, že využívanie anglického jazyka na hodinách je opodstatnenou požiadavkou predovšetkým vo výučbe úplných začiatočníkov (máme na mysli používatel'ov jazyka z neslovanského prostredia). Nielen z toho dôvodu, že plní funkciu metajazykovú, ktorá slúži na opis osvojovaného jazyka, k lingvodidaktickej prezentácii všetkých jeho jazykových rovín a plánov, k precvičeniu učiva apod. (Hrdlička, 2010). Slúži zároveň ako dorozumievací jazyk k vysvetl'ovaniu medzikultúrnych rozdielov alebo podobností, ku konverzáciám o každodennom živote na Slovensku, ked'že po príchode na Slovensko je každý zahraničný študent vystavený situáciám, ktoré si nevie vysvetlit', nepozná ich, potrebuje sa s nimi oboznámit', pýta sa na rady ako postupovat' v situáciách, v ktorých sa ocitne a nerozumie reakciám, ktoré vyvolajú jeho otázky, prístupy alebo komunikácia v každodennom živote na Slovensku. V praxi sa nám osvedčilo poskytnutie časového priestoru, napr. 10 - 15 minút na konci hodiny, počas ktorých majú zahraniční študenti možnost' dostat' odpovede na otázky súvisiace s každodenným životom na Slovensku. Uvedený prístup odporúčame predovšetkým v prvom semestri štúdia zahraničného študenta. Je však nutné zdôraznit' a súhlasit's názorom, že vol'ba mediačného jazyka by mala byt' koncepčná, premyslená a systematická. Pokial' nebude používanie mediačného jazyka koncepčné, pokial' sa nebudú používat' jasné pravidlá a bude dochádzat' $\mathrm{k}$ náhodnému striedaniu kódu komunikácie alebo k jeho miešaniu, môže to situáciu učiaceho sa cudzí jazyk v procese nadobúdania znalostí cudzieho jazyka dost' zásadným spôsobom komplikovat' (Hrdlička, 2010, s. 220).

\section{Odborný jazyk a začiatočníci}

Zahraniční študenti na Lekárskej fakulte UPJŠ, ktorí už v 2. alebo 3.ročníku štúdia prichádzajú do kontaktu so slovensky hovoriacim pacientom v nemocnici, si potrebujú dovtedy osvojit' základnú slovnú zásobu, výslovnost', frázy, tak aby boli pripravení na základnú komunikáciu s pacientom. Musia sa vediet' pacienta opýtat' na jeho zdravotný stav a zároveň porozumiet' pacientovi. To znamená, že s výučbou lekárskej slovenčiny je potrebné začat' hned' v zimnom semestri 1.ročníka štúdia, t. j. v období, ked' študent 
ešte nemá osvojené základy všeobecného slovenského jazyka. To samozrejme, kladie vysoké nároky na učitela, ktorý je postavený pred zložitú úlohu. Musí popri výučbe základov slovenčiny dokázat' študentov naučit' aj základy lekárskej terminológie a komunikácie v slovenčine. Vyučujúci tak musí zladit’ osvojovanie si základov všeobecnej slovenčiny zároveň so získavaním základov odbornej komunikácie v slovenčine so zameraním na lekárske prostredie. Musíme opät' zdôraznit' ten fakt, že primárnou ciel'ovou skupinou sú študenti, ktorí majú nulové resp., minimálne znalosti slovenského jazyka, čo prípravu študenta v oblasti osvojovania si základov odborného jazyka st’ažuje. Zo strany učitel'a je potrebné vel'mi citlivo zvažovat' postupnost' a nadväznost' jednotlivých tém, obt’ažnost' slov, fráz atd'., tak aby príprava poskytla študentovi a zároveň aj vyučujúcemu metodicky premyslenú stratégiu, ktorá čo najefektívnejším spôsobom pomôže študentovi osvojit' si lekársku slovenčinu. Na túto skutočnost' je potrebné dbat' aj pri príprave učebných materiálov pre študentov. Jednotlivé témy zamerané na osvojovanie si odborného jazyka medicíny musia byt' radené logicky a zabezpečovat' gradáciu procesu osvojovania si lekárskej slovenčiny. Naša skúsenost' s jazykovou prípravou zahraničných študentov nás presviedča o tom, že hned' na začiatku jazykovej výučby (jazyková úroveň A1) je dôležitý nácvik lexiky súvisiacej s pomenovaniami častí tela, príznakov ochorení, s návštevou u lekára a osvojením si a rešpektovaním zdvorilostných zásad pri komunikácii lekára s pacientom v slovenskom jazyku. Študenti si potrebujú osvojit' rečové zručnosti na vyjadrenie stavov a pocitov, nutnosti niečo urobit', učia sa popísat' minulé zdravotné problémy, nepríjemné pocity a bolesti, poskytnút' základné osobné údaje pre lekára. Rozvíja sa ich dialogický prejav aj $\checkmark$ rámci komunikácie lekára s pacientom. Lexika ponúka pomenovania častí l'udského tela, názvy chorôb, typy bolestí, pomenovanie zdravotných t’ažkostí a úrazov, častí nemocnice. Sociolingvistické kompetencie študenta sú zacielené na porozumenie bežným textom a oznamom, napr. údaje o lieku, o cene, ordinačné hodiny, na spôsob komunikácie so slovenským pacientom (Petruňová - Timková, 2017, s.176). Ciel'om vyššej jazykovej úrovne A2 je nadviazat' na vedomosti získané na úrovni $A 1$ tak, aby frekventant zdokonal'oval svoju schopnost' komunikovat' v slovenskom jazyku. Študent úrovne $\mathrm{A} 2$ sa $v$ rámci osvojovania si odborného jazyka medicíny učí pomenovat' pracoviská $v$ nemocnici, vyšetrenia $v$ nemocnici, lekárov - špecialistov, identifikovat' názvy oddelení v nemocnici, orientovat' sa v nemocnici. Osvojuje si frázy týkajúce sa vyšetrenia u lekára na oddelení, hospitalizácie, komunikácie lekára s pacientom. Nácvik lexiky súvisí s pomenovaním oddelení $\mathrm{v}$ nemocnici, komunikáciou pri vyšetrení $\mathrm{v}$ nemocnici, prijímaním pacienta do nemocnice a komunikáciou počas hospitalizácie. $V$ rámci sociokultúrnych kompetencií sa študent naučí jednoduchými jazykovými prostriedkami porovnat' nemocnicu na Slovensku a nemocnicu vo svojej krajine, platenie za služby v zdravotníctve a pod. (Petruňová - Timková, 2017, s.181).

\section{Autentický jazyk v medicínskej slovenčine}

Ďalšou oblast'ou, ktorá predstavuje úskalia pre pedagóga pri výučbe slovenčiny ako cudzieho jazyka, resp., medicínskej slovenčiny, je potreba zohl'adnit' hovorový štýl jazyka pri komunikácii lekár - pacient. Častokrát sa totiž stretávame s tým, že zahraničný študent medicíny je počas praxe v nemocnici vystavený neformálnemu jazyku, ktorý pacient používa pri opise svojich zdravotných problémov. O to náročnejšie je pre zahraničného študenta osvojenie si hovorovej lexiky pri opise zdravotných problémov zo strany pacienta, a jeho rozpoznanie pri komunikácii s pacientom. Zahraniční študenti častokrát čelia komunikačným situáciám, v ktorých len s t’ažkost’ami porozumejú odpovediam pacientov. Príprava zahraničného študenta je o to náročnejšia, že do hovorového štýlu jazyka častokrát vstupujú podoby dialektu, či už na zvukovej, gramatickej alebo lexikálnej úrovni. Je však potrebné zo strany učitel'a zaradit' do výučby 
medicínskej slovenčiny okrem iného aj autentický, 'neprikrášlený', hovorový štýl jazyka, ktorý pacient používa pri popise svojho zdravotného stavu.

\section{Záver}

Na záver je možné konštatovat', že výučba slovenčiny ako cudzieho jazyka má svoje špecifiká, ktoré je potrebné pri príprave učitel'a slovenského jazyka ako cudzieho jazyka dôsledne spoznávat', oboznamovat' sa s nimi a prinášat' riešenia , ktoré napomôžu efektívnejšiemu osvojovania si slovenčiny zo strany zahraničných študentov. Pre pedagóga prináša mnohé riešenia až samotná pedagogická prax a skúsenosti nadobudnuté v každodennej práci so zahraničnými študentmi na hodinách slovenského jazyka. V článku sme zhrnuli len niektoré oblasti, ktoré je potrebné si všímat' a venovat' im pozornost' predovšetkým v neslovanskom prostredí jazykovej triedy, nakol'ko práve uvedené jazykové auditórium je vzhl'adom na odlišnost' osvojovaného slovanského jazyka (slovenského jazyka) a natívneho neslovanského jazyka (príp. iného neslovanského komunikačného jazyka) študenta vystavené náročnejšiemu procesu jazykového vzdelávania v porovnaní so študentmi pochádzajúcimi zo slovanského prostredia.

\section{Literatúra}

Hrdlička, M. (2010): K otázce mediačního jazyka ve výuce češtiny pro cizince. In: „Bohemistyka” 2010, nr 3, 217 - 224.

Kavečanská, A., Kolaříková, Z., Petruňová, H.- Timková, R. (2014): Cudzie jazyky na univerzite Pavla Jozefa Šafárika $v$ Košiciach - minulost', súčasný stav a možnosti jazykovej výučby. In: Trendy $v$ jazykovém vzdělávaní $v$ terciární sféře. Činnost jazykových center na filozofických fakultách $v$ České republice a na Slovensku [elektronický zdroj], Olomouc, Univerzita Palackého v Olomouci, 1-6.

Panocová, R., petruňová, H. Timková, R. (2006): Spoločný európsky referenčný rámec pre jazyky a jeho aplikácia na odborný anglický jazyk medicíny, In: Zborník medzinárodnej konferencie Odborný jazyk na vysokých školách II. Praha, 110-112.

Petruňová, H. - Timková, R. (2012): Slovenčina pre medikov ako praktický odborný cudzí jazyk. In: Lekárska a farmaceutická terminológia $v$ teórii a praxi : zborník príspevkov z konferencie 24. mája 2012 v Martine. - Martin : Univerzita Komenského v Bratislave, Jeseniova lekárska fakulta v Martine, $63-67$.

Petruňová, H. - Timková, R. (2017): Slovenčina ako cudzí jazyk - rozvoj elementárnych jazykových zručností zahraničných študentov na Lekárskej fakulte UPJŠ. In: Universitas Comeniana. Philologica LXXVI, Lingua academica 5. - Bratislava : Univerzita Komenského v Bratislave, 169-182.

Spoločný európsky referenčný rámec pre jazyky (2006): Učenie sa - vyučovanie hodnotenie. Bratislava : Štátny pedagogický ústav, 252 s.

\section{Adresa autora}

Doc. Mgr. Renáta Timková, PhD.

Katedra anglistiky a amerikanistiky, Filozofická fakulta, UPJŠ v Košiciach

Moyzesova 9, 04001 Košice

renata.timkova@upjs.sk 


\title{
ČINNOSTI NA UŽITÍ SUDOKU VE VÝUCE MATEMATIKY NA 1. STUPNI ZÁKLADNÍ ŠKOLY
}

\section{ACTIVITIES USING SUDOKU IN TEACHING MATHEMATICS AT THE 1ST LEVEL OF ELEMENTARY SCHOOL}

\author{
Jitka Trymlová \\ Katedra matematiky, fyziky a technické výchovy, Fakulta pedagogická, ZČU v PIzni \\ Šárka Pěchoučková \\ Katedra matematiky, fyziky a technické výchovy, Fakulta pedagogická, ZČU v PIzni \\ Jan Frank \\ Katedra matematiky, fyziky a technické výchovy, Fakulta pedagogická, ZČU v PIzni
}

\begin{abstract}
:
The logical game SUDOKU has become a very widespread phenomenon during a relatively long period of its existence. Especially in recent years, when it began to appear regularly not only in printed periodicals, but also on the Internet, solving SUDOKU is a very popular activity throughout Europe, including the Czech Republic. SUDOKU also appears in some mathematics textbooks. For the 2nd, 3rd and 4th year of elementary school, we prepared planar SUDOKU and SUDOKU with solids, which the pupils solved graphically or by manipulation, while frontal teaching, group and individual work were used. The main objective was to find out how SUDOKU can be used in teaching mathematics at the 1 st level of elementary school, which competencies can be developed with this game and how the work of pupils differs in these years. Based on the survey, it turned out that in addition to competencies for problem solving, communicative competences, learning competencies, social, personnel and work competencies were also developed for pupils. The pupils of the 4th year, in whom mutual cooperation was used in group work, coped best with the assigned tasks.
\end{abstract}

Key words:

Sudoku, teaching mathematics, key competencies, problem solving

\section{Úvod}

Logická hra SUDOKU se během poměrně dlouhé doby své existence stala velmi rozšiřreným fenoménem. Zejména $\mathrm{v}$ posledních letech, kdy se začala pravidelně objevovat nejen $v$ tištěných periodikách, ale $\mathrm{i}$ na internetu, je luštění či doplňování SUDOKU velice oblíbenou aktivitou v celé Evropě včetně České republiky. Tuto hru najdeme i mezi úlohami rekreační matematiky. Děti se tedy se SUDOKU mohou běžně setkávat ve svém okolí. Proto se domníváme, že je přínosné zabývat se tím, jaké možnosti může tato logická hra přinést při zapojení do vyučování matematiky.

Zapojení SUDOKU do vyučování matematiky na prvním stupni může být pro žáky určitým oživením. Zároveň díky velkému množství možností, jak tuto logickou hrou při vyučování využít, může poskytnout nové cesty, jak při hodinách matematiky se žáky pracovat. 


\section{Pravidla SUDOKU}

Logická hra sudoku má ve své klasické formě podobu čtverce tvořeného 81 poli. $\checkmark$ každém řádku a každém sloupci se nachází devět polí. Celý čtverec je rozdělen na 9 vnitřních čtverců, které obsahují 3 x 3 pole. Zadání je tvořeno několika vyplněnými poli, na jejichž základě jsou doplňována pole prázdná. [1] Postupujeme podle pravidla: každý řádek, každý sloupec a každý vnitřní čtverec je tvořen číslicemi od 1 do 9 , přičemž se žádná z nich nesmí opakovat dvakrát. [2] Zadání SUDOKU může mít mnoho variant, které mohou být různě obtížné v závislosti na počtu a rozmístění číslic, které tvoří zadání. [3] U lehčích typů zadání postupně doplňujeme číslice, u kterých jsme si jisti, že do daného čtverce patří. Při doplňování složitějších typů SUDOKU musíme obvykle využít jako pomůcku vpisování možných čísel do čtverců, z nichž potom postupným vyřazováním vyplyne správná možnost. Je nutné si dát však pozor, aby se naše SUDOKU nestalo díky vpisování mnoha číslic přiliš nepřehledným. [4]

\section{Práce se žáky na 1. stupni základní školy}

Ve druhém, třetím a čtvrtém ročníku základní školy byla realizována sonda, jejímž cílem bylo vytvořit činnosti na užití SUDOKU ve výuce matematiky ve vybraných ročnících základní školy, uskutečnit je se žáky a provést reflexi. V každém ročníku jsme sondě věnovali dvě za sebou následující vyučovací hodiny a pracovali podobným způsobem. Nejdříve proběhla frontální práce se žáky, na kterou navazovala skupinová práce a samostatná práce s pracovním listem. Pro rychlejší žáky byl pak ještě připraven úkol vytvořit zadání vlastního SUDOKU.

Cílem frontální práce bylo, aby žáci pochopili pravidla této hry a dovedli určit místo, ze kterého je vhodné sít' doplňovat. Žáky jsme tedy nejdříve seznámili s principem hry, poté chodili postupně $\mathrm{k}$ tabuli po jednom a doplňovali předkreslenou sít'. Začínali jsem sítí s menším počtem čtverců, která nebyla rozdělena na vnitřní subčtvece. Vyvolaný žák zdůvodnil, jakou číslici a proč doplní do zvoleného pole, ostatní jeho volbu bud'schválili, nebo opravili.

Skupinová práce byla připravena pro skupinu čtyř nebo pěti žáků. Každá skupina dostala na čtvrtce velikosti A3 předkreslenou prázdnou sít', geometrická tělesa (krychle, kvádry, jehlany, válce) a na listu papíru formátu A4 zadanou úlohu. Úkolem žákủ bylo umístit do prázdné sítě tělesa podle zadání a poté SUDOKU vyřešt. Pro každou skupinu byly připraveny tři nebo čtyři úkoly se vzrưstající náročností. Obtížnost se zvyšovala zvětšením sítě nebo přidáním vnitřního rozdělení sítě na čtverce.

Náročnost úkolů také rostla $v$ zadání úkolů v rámci samostatné práce. Zvyšoval se celkový počet čtverců tvořících sít' SUDOKU a v nejnáročnějších zadáních byla sít' rozdělena na vnitřní čtverce. Také použití jedné barvy namísto tří nebo čtyř při dokreslování geometrických tvarů a využití písmen v porovnání s číslicemi zvyšovalo náročnost řešení.

Jako nadstandardní úkol pro rychlejší žáky byla zvolena příprava zadání vlastního SUDOKU.

Vzhledem k omezenému rozsahu článku uvedeme v následujícím textu ukázky pouze vybraných úkolů z každého ročníku a postřehy z řešení dalších úloh.

Ve druhém ročníku, který navštěvovalo 26 žáků, jsme pro frontální práci použili SUDOKU tvořené polystyrénovými aplikacemi (obr. 1), jež žáci řešili manipulativně, a SUDOKU s číslicemi (obr.2).

Pro doplnění SUDOKU použij jablko, hrušku a banán.
Pro dopInění SUDOKU použij

číslice 1, 2, 3 


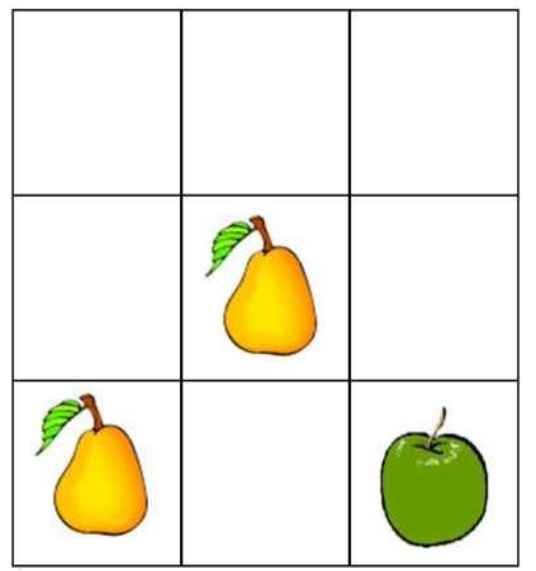

Obr. 1 Zadání prvního úkolu

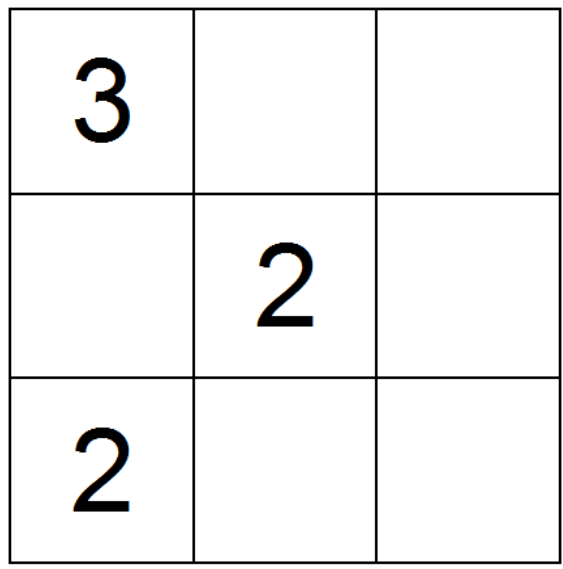

Obr. 2 Zadání druhého úkolu

Ve druhém ročníku bylo patrné, že se žáci se SUDOKU v hodinách matematiky často setkávají. Frontální práci zvládli rychle a správně, s pochopením pravidel neměli žádné velké problémy. Chybovali pouze ve vyjadřování toho, kam daný objekt nebo číslici umístit. Většinou říkali: „dolů, doprostřed, vpravo“, ale neupřesnili, zda myslí sloupec či rádek. Při skupinové práci pracovaly jednotlivé skupiny rozdílným způsobem. $V$ některých se do úkolu zapojovali všichni členové, domlouvali se a řešili úkol společně. Vostatních skupinách se žáci rozdělili, pracovali ve dvojicích nebo samostatně a společně pak vytvořili konečné řešení. Dva úkoly byly tvořeny sítěmi $s 9$ čtverci, v posledním úkolu se objevila sít' obsahující 16 čtverců. Všechny skupiny vyřešily úspěšně všechna zadání, $V$ prvním úkolu samostatné práce žáci do sítě formátu 3 čtverce $\times 3$ čtverce dokreslovali ovoce, úspěšnost řešení tohoto úkolu byla $88 \%$. Druhá sít' stejného formátu obsahovala číslice 1, 2, 3, správně ji doplnili všichni žáci stejně jako sít' v následujícím úkolu, kde se pracovalo s červenými čtverci, zelenými trojúhelníky a modrými kruhy. Do poslední sítě dopisovali žáci číslice $1,2,3,4$, úspěšnost řešení tohto úkolu byla $77 \%$.

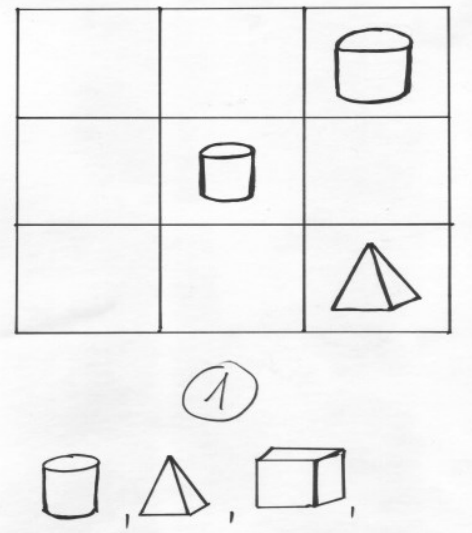

Obr. 3 Zadání úkolu

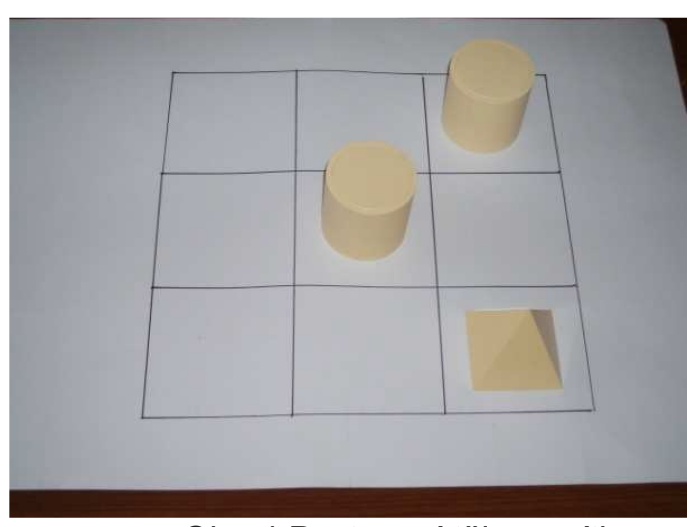

Obr. 4 Postavení těles v síti

Pravidla SUDOKU byla v třetím ročníku (18 žáků) vysvětlována při frontální práci na dvou úkolech. Do první sítě se 16 čtverci doplňovali žáci číslice 1, 2, 3, 4, druhá sít' stejných rozměrů byla ještě rozdělena na 4 subčtverce a byla vyplněna písemny $A, B, C, D$. 


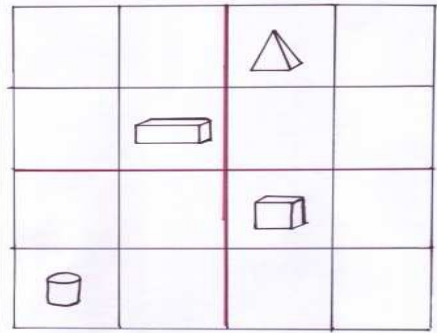

(1)

Obr. 5 Zadání úkolu

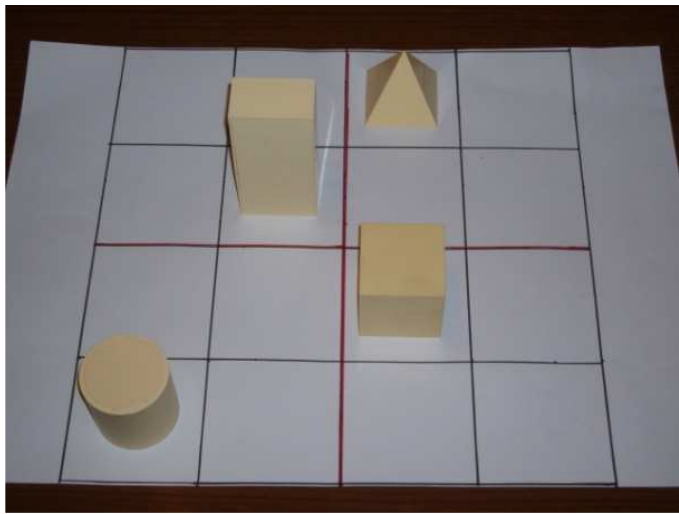

Obr. 6 Postavení těles v SUDOKU

Druhý úkol byl tedy obtížnější.pro žáky bylo náročné si uvědomit, že se každý symbol musí objevit jen jednou nejen v řádku a sloupci, ale i v každém vnitřním čtverci. Před plněním úkolů ve skupinách jsme se žáky zopakovali tělesa a jejich vlastnosti, přičemž jsem používali tělesa, která měly skupiny $k$ dispozici při plnění dalších úloh. Objevily se problémy s rozlišováním prostorových a rovinných útvarů. Pro vlastní skupinovou práci byly původně připraveny tři úkoly. Zadání prvního úkolu ukazují obrázky 3 a 4 . Druhý úkol (obr. 5, obr. 6) byl pro žáky velmi náročný a žádné skupině se ho nepodařilo správně vyřešit. $Z$ časových důvodů proto již nebyl zadán třetí úkol. $V$ rámci samostatné práce doplňovali žáci čtyři sítě o 16 polích. První obsahovala číslice 1, 2,3,4 a vyřešilo ji správně $83 \%$ žáků. Do druhé sítě dokreslovali žáci modré rovinné útvary (trojůhelník, čtverec, obdélník, kruh), úspěšnost řešení této úlohy byla $95 \%$. Sít' ve třetím úkolu byla rozdělena na 4 vnitřní čtverce a obsahovala modré trojúhelníky, žluté obdélníky, červené čtverce a zelené kruhy. Správně tuto úlohu vyřešilo $56 \%$ žáků. U zbylých žáků se objevovaly $v$ subčtvercích dva stejné symboly. Poslední sít' byla také rozdělena na 4 vnitřní čtverce a objevila se v ní písemna $\mathrm{E}, \mathrm{F}, \mathrm{G}, \mathrm{H}$. Úspěšnost řešení tohoto úkolu byla pouze $17 \%$. Vliv na úspěšnost řešení jednotlivých úkolů žáků třetího ročníku mohl mít podle našeho názoru i fakt, že se tito žáci na rozdíl od žáků druhého ročníku se SUDOKU při výuce matematiky dříve vůbec nesetkali.

Vzhledem k tomu, že se připravené úkoly ukázaly pro žáky třetího ročníku jako náročné, rozhodli jsme se stejné zadání předložit v rámci frontální a skupinové práce i sedmnácti žákům 4. ročníku, kteří rovněž neměli z předchozí výuky matematiky se SUDOKU žádné zkušenosti. Textová zadání úkolů při samostatné práci byla také stejná jako $\checkmark$ předchozím ročníku, lišila se pouze doplňovanými symboly nebo jejich polohou ve čtvercové síti. Při frontální práci neměli s prvním úkolem (sít’ bez subčvercư) žáci sebemenší problémy. Na doplnění SUDOKU ve druhém úkolu, kde jsme pracovali se sítí rozdělenou na vniřní čtverce, potřebovali žáci více času než na první úkol, ale nevyžadovali př́lišnou nápovědu. Ve všech skupinách si žáci pomáhali, domlouvali se a řešili úkol společně, podařilo se tedy všem správně doplnit zadané úkoly. Samostatná práce byla zadána na pracovním listu se čtyřmi úkoly. První úkol na doplňování číslic 1 , 2, 3, 4 zvládli bezchybně všichni žáci. Druhý úkol (obr. 7) se ukázal jako nejobtížnější, vyřešilo ho správně 65 \% žáků. Úspěšnost řešení třetího úkolu (obr. 8) byla 76 \% a se čtvrtým úkolem (sít' obsahující čtyři vnitřní čtverce a písmena $K, L, M, N$ ) si úspěšně poradilo $88 \%$ žákư. 


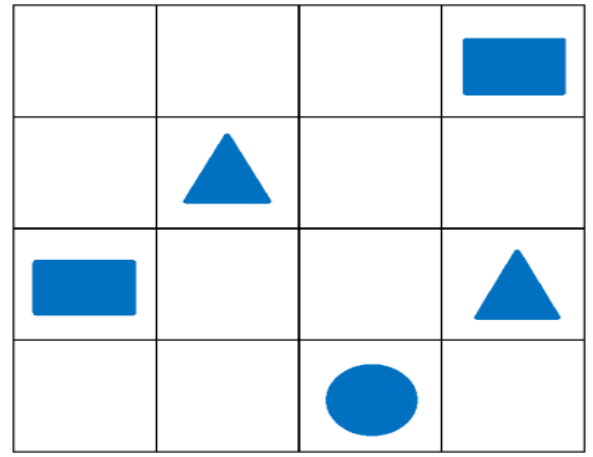

Obr. 7 Zadání úkolu

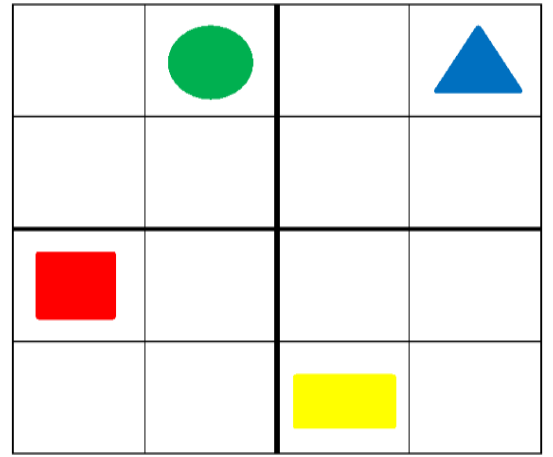

Obr. 8 Zadání úkolu

\section{Závèr}

Výše popsaná sonda naznačila různé způsoby využití hry SUDOKU v hodinách matematiky a zároveň možnosti, jak netradiční formou rozvíjet u žáků logické myšlení a schopnost řešit problémy. Úspěšnost řešení jednotlivých úloh mimo jiné závisí na zkušenostech s touto hrou. Žáci vyšších ročníků jsou schopni řešit náročnější úkoly. Rádi bychom se touto problematikou dále zabývali a zaměřili se ještě na další ročníky 1. stupně.

\section{Literatura}

[1] Hra sudoku. Dostupné na https://sudokus.cz/pravidla/

[2] Pravidla sudoku. Dostupné na https://sudokuzdarma.cz/pravidla-sudoku/

[3] Jak řešit sudoku?. Dostupné na https://www.cshak.cz/jak-resit-sudoku

[4] Jak luštit sudoku. Dostupné na https://sudokuonline.cz/navod/

\section{Adresy autorov}

\section{Mgr. Jitka Trymlová}

Katedra matematiky, fyziky a technické výchovy, Fakulta pedagogická, ZČU v PIzni Klatovská 51, 30800 Plzeň

jitka.trymlova@gmail.com

\section{PhDr. Šárka Pěchoučková, Ph.D.}

Katedra matematiky, fyziky a technické výchovy, Fakulta pedagogická, ZČU v Plzni Klatovská 51, 30800 Plzeň

pechouck@kmt.zcu.cz

\section{Mgr. Jan Frank, Ph.D.}

Katedra matematiky, fyziky a technické výchovy, Fakulta pedagogická, ZČU v PIzni Klatovská 51, 30800 Plzeň

frankjan@kmt.zcu.cz 


\title{
ZVYŠOVANIE EFEKTIVITY VÝUČBY $V$ PRIMÁRNOM PRÍRODOVEDNOM VZDELÁVANÍ PROSTREDNÍCTVOM ZÁŽITKOVÉHO UČENIA SA
}

\section{INCREASING THE EFFECTIVENESS OF TEACHING IN PRIMARY SCIENCE EDUCATION THROUGH EXPERIENCE- BASED LEARNING}

\author{
Miriam Uhrinová \\ Katedra predškolskej a elementárnej pedagogiky, Pedagogická fakulta, KU \\ v Ružomberku \\ Ivana Prachárová \\ Katedra predškolskej a elementárnej pedagogiky, Pedagogická fakulta, KU \\ v Ružomberku \\ Jan Tirpák \\ Katedra speciální a sociální pedagogiky, Pedagogická fakulta, UJEP v Ústí nad Labem
}

\begin{abstract}
:
Education in natural sciences is a long-term process in which the teacher's personality also plays an important role. It is an important motivating and driving factor of the educational process. The teacher can use various methods during the educational process at school to develop pupils' literacy in natural sciences. One of them is experience-based learning. Experience-based learning should become a part of the activating teaching methods that we use in learning about nature and its laws, in order to develop not only the cognitive domains, but also the affective domains. Experiential learning positively reinforces pupils' sensitive perception of the natural environment, which increases their interest in learning about natural phenomena and laws. The paper underlines the potential and the impression of this progressive educational method, which enables the children of younger school-age to learn about nature and to discover its laws experientially. It presents the results of the research survey aimed at determining the effectiveness of experiential methods on the pupils with respect to their learning outcomes in primary education of natural sciences. The paper presents the contribution and the convincing influence of the implementation of experience-based learning methods in natural science classes, in terms of learning results of pupils in the fourth year of elementary school.
\end{abstract}

Key words:

experience-based learning, teacher, natural science education, primary education

\section{Úvod}

Prírodovedné vzdelávanie je dlhodobý proces a zohráva významnú úlohu v rozvoji spoločnosti i rozvoji ludskej kultúry. Každý l'udský jedinec si sukcesívne rozvíja a formuje prírodovednú gramotnost', pričom pod pojmom prírodovedná gramotnost' rozumieme predovšetkým zoznam toho, čo všetko človek potrebuje, aby porozumel prírodným aspektom ovplyvňujúce jeho život, dokázal vysvetlit' základné prírodné javy vo svojom 
okolí, poznal fundamentálne pojmy, zákony a metódy prírodných vied, vedel pracovat' s grafmi, tabul'kami, schémami i mapami, v neposlednom rade, aby bol schopný vytvárat' si svoj vlastný úsudok o vierohodnosti poznatkov (Roberts, 2007; Svobodová, 2013). Medzinárodné výskumy IEA PIRLS a TIMSS čoraz častejšie poukazujú na neuspokojivo rozvinutú prírodovednú gramotnost' žiakov a významný pokles v ich vedomostiach či zručnostiach $v$ predmetnej oblasti, t.j. v oblasti prírodovedy. Ako uvádza Ramsden (1998), mnohí žiaci považujú prírodovedné predmety za zložité, nesúvisiace s praktickým životom. Na túto skutočnost' poukazujú aj výsledky niektorých výskumov, ktoré ilustrujú, že negatívne postoje žiakov k prírodovedným predmetom do vel'kej miery súvisia $\mathrm{s}$ nedostatkom prepojenia vedy s reálnym životom (Osborne, Simon \& Collins, 2003).

Prírodovedné predmety svojím činnostným a bádatel'ským charakterom vyučovania umožňujú žiakom hlbšie porozumiet' zákonitostiam prírodných procesov, a tým si aj uvedomovat' užitočnost' prírodovedných poznatkov pre ich kontinuálnu aplikáciu v praktickom živote (Brtnová-Čepičková, 2005). Na efektívne premostenie vedy $s$ reálnym životom tak možno v edukačnej praxi využívat' vhodné edukačné stratégie. $V$ tomto kontexte má nezastupitel'né miesto aj osobnost' učitel'a, ktorý je významným motivujúcim činitel'om a hybným faktorom edukačného procesu. V súčasnej edukačnej realite je to práve učitel', ktorý má hl'adat' cestu, ako strategicky a účinne prepájat' teóriu s praxou a ako efektívne rozvíjat' u žiakov klúčové kompetencie, pričom žiakov v prvom rade vníma ako subjekty edukácie a nepokladá ich len za pasívne objekty vzdelávania. $\checkmark$ samotnom vyučovaní nejde totiž len o prenos poznatkov od aktívneho učitel'a $k$ pasívnemu žiakovi. Úlohou učitela je predovšetkým žiaka aktivizovat' a motivovat'. Učitel'ova aktivita má spočívat' hlavne $v$ plánovaní a príprave edukačného procesu, v ktorom majú byt' aktívni najmä žiaci a on má byt' ich pomocníkom pri konštruovaní ich autentického poznania. Konštruktivisticky postavená výučba so zretel'om na prírodovedné vzdelávanie tkvie na základoch poznatkov, skúseností a predstáv žiakov, ktoré sa častokrát spájajú práve s ich zážitkami a s ktorými vstupujú do edukačného procesu. Súčasná edukačná realita si tak vyžaduje učitel'a s adekvátnymi profesijnými kompetenciami, ktorý bude danú skutočnost' akceptovat' a efektívne bude implementovat' do edukačného procesu pri rozvíjaní prírodovednej gramotnosti aj metódy zážitkového učenia sa.

\section{Zážitkové učenie sa}

Jednou z oblastí, ktoré predkladajú kritériá ukazovatel'ov kvality profesijných činnosti učitel'a, je oblast' procesu učenia. $V$ tejto kontinuite sa v odbornej literatúre uvádza, že učitel' používa také didaktické stratégie, ktoré umožňujú každému žiakovi porozumiet' edukačnému obsahu, rozvíjat' žiaduce kompetencie a získat' vnútornú motiváciu i schopnosti k celoživotnému vzdelávaniu a poznávaniu. $\mathrm{V}$ kontexte týchto profesijných kompetencií učitel' využíva množstvo metód a foriem práce s dôrazom na aktívne učenie sa žiakov (Thomková a kol., 2012). So zretel'om na prírodovedné vzdelávanie má učitel' široké spektrum možností využívania rôznych stratégií v edukačnom procese. Jednou z nich je aj zážitkové učenie sa, ktoré považujeme za významný determinant rozvijania prírodovednej gramotnosti u žiakov v primárnom vzdelávaní práve preto, že poznávanie diet'at’a mladšieho školského veku je prevažne skúsenostné a zážitkové, zároveň je silne emocionálne poznačené a detské interpretácie prírodných javov sú slovami Gavoru (2007) neobyčajne pevné.

Súvzt'ažne s vyššie uvedeným by sa učenie sa prostredníctvom zážitku malo stat' súčast'ou aktivizujúcich metód, ktoré využívame pri poznávaní prírody a jej zákonitostí, aby sme u žiakov rozvíjali nielen kognitívnu stránku, ale zároveň aj stránku afektívnu. Súhlasne s Houškom (1991) konštatujeme, že výhody zážitkového učenia sa spočivajú v zapájaní nielen kognitívnych, ale aj emocionálnych procesov, čo vyvážene pôsobí na 
emocionálnu aj racionálnu zložku osobnosti diet’at’a (žiaka). Zároveň sú podporované kognitívne, sociálne, emocionálne zručnosti a tvorivé dimenzie osobnosti. Zážitkové učenie sa tak uspokojuje u žiaka jednak potrebu tvorivej aktivity, jednak potrebu zmysluplnosti sveta práve pomocou prepájania získavaných poznatkov s realitou a praxou.

Zážitkové učenie sa u žiakov pozitívne posilňuje citlivé vnímanie prírodného prostredia, čím sa u nich zvyšuje aj záujem o poznávanie prírodovedných javov a zákonitostí a prepája sa vedecké skúmanie reality s praktickým životom. Pri vhodnej implementácii zážitkových metód do edukačného procesu sa môžu stat' východiskom pre inovačné procesy zamerané na skvalitňovanie výučby, ktoré zdôrazňujú potrebu vlastnej aktivity žiakov a zároveň do vyučovania prinášajú tvorivo- humanistický rozmer s akceptáciou osobnosti žiaka a s rešpektovaním jeho potrieb a skúseností.

O zážitkovom učení sa hovoríme vtedy, ak „priama interakcia $s$ vecami, prírodou a $s$ inými lud'mi prináša zmeny v správaní a v interpretácii prežitého“ (Kariková, 2001, s. 38). Podl'a Karikovej (2002) je zážitkové učenie sa charakterizované ako:

- aktívne - uplatňuje a rozvíja sa aktivita žiakov;

- participatívne - aktívni sú nielen učitelia, ale aj žiaci, ktorí sú pri prijímaní informácii iniciatívni a tvoriví, informácie prijímajú stimuláciou ich vlastných procesov myslenia, podporujú vytváranie nových nápadov a prístupov; učenie sa je založené na zážitku a skúsenosti, ktoré vedú k priamej interakcii s prírodou, inými l'ud'mi, predmetmi a táto interakcia má prinášat' zmeny v správaní;

- kooperatívne a interaktívne - podporuje medziludské vzt'ahy, otvorenú a dôslednú komunikáciu, pričom sa podporuje práca v skupinách, vzájomná pomoc, spolupráca, prijatie zodpovednosti;

- kreatívne - vyžaduje rozvoj vyšších kognitívnych spôsobilostí, rozvoj riešenia problémov, vytvárania perspektív, spojenie racionálneho a intuitívneho myslenia.

Práve tieto aspekty zážitkového učenia sa považujeme za významné determinanty pri rozvíjaní prírodovednej gramotnosti žiakov, a to najmä so zretel'om na rozvíjanie ich schopností vedeckej práce.

Do činností, ktoré evokujú učenie sa a poznávanie, by mal učitel' komponovat' také transparentné znaky zážitkového učenia sa, ktoré spúštajú zážitok a umožňujú jeho premenu. Doušková s Kružlicovou (2011) medzi hlavné atribúty začleňujú najmä:

- Vlastnú vnútornú iniciatívu ako pocit objavovania, spoznávania a porozumenia.

- Objavnost' uskutočňovanú takými učebnými situáciami, ktoré prenikajú do skutočnej reality, poskytujú spoznanie nových pojmov, faktov, informácií a opakovane prinášajú radost' z poznávania.

- Vzájomnú komunikáciu, ktorá dáva možnost' vymieňat' informácie medzi zúčastnenými verbálne i neverbálne.

- Praktické činnosti v zastúpení manipulácie s novými predmetmi, experimentovania i hrových aktivít.

- Kvalitný autentický zážitok získavaný v situáciách prežívaných citmi i rozumom.

- Celostnost' vyučovania, realizovanú hodnovernými situáciami, do ktorých žiaci zapájajú všetky zmysly, ba aj obe mozgové hemisféry. V tejto súvislosti uvádza aj Vargová (2012), že v procese zážitkového učenia sa diet’a (žiak) vníma všetkými zmyslami, teda všetky svoje zmysly rozvíja a tak prijíma viac informácií, ktoré nadobúdajú efektívnejšiu kvalitu ako pri inom učení sa.

Z hladiska zážitkového a skúsenostného poznávania je dôležité neodovzdávat' žiakom len hotové informácie z prírodovednej oblasti, ale poskytnút' im aj priestor pre získavanie zážitkov a nových skúseností v samostatnom objavovaní a bádaní prírody. Zážitky 
a metódy zážitkového učenia sa sú súčast'ou skúsenostného vyučovania, činnostne zameraného vyučovania a bádatel'sky orientovaného vyučovania (Uhrinová, 2015). Sú neodmyslitel'nou súčast'ou aj praktických terénnych prírodovedných aktivít, realizovaných $v$ exteriéri. Pre žiakov sa $v$ nich otvára priestor pre ich vlastnú aktivitu a slúžia na aktiváciu ich poznatkov, rozvoj ich kompetencií a konštruktívneho myslenia. Sú dôležité aj vzhl'adom k uplatňovaniu konštruktivistického prístupu v prírodovednom vzdelávaní. Priamo v prírode sa otvára i priestor pre rozvíjanie environmentálnej senzitivity. Rozvíjanie prírodovednej gramotnosti je úzko späté s rozvíjaním environmentálnej gramotnosti žiakov. Ako uvádzajú Macko a Blahútová (2010), odporúča sa zabezpečit' žiakom častý kontakt s prírodou a priestor pre samostatné interakcie s prírodou a pre jej poznávanie. Kontakt s prírodou by mal byt' pre žiakov príjemný a bez stresujúcich zážitkov.

V súvislosti so zážitkovým a skúsenostným učením sa je známy model Kolba (Kolbov cyklický model učenia sa), ktorý schematicky zahŕňa konštitúcie zážitkového učenia sa (Kolb, 1984, McLeod, 2017).

Uviedli sme niektoré z pozitív, ktoré so sebou prináša zážitkové učenie sa. Je však zážitkové učenie sa efektívne z hl'adiska rozvíjania prírodovednej gramotnosti u žiakov? Využívajú učitelia metódy zážitkového učenia sa na rozvíjanie prírodovednej gramotnosti? Zlepšia sa pri ich implementácii do edukačného procesu učebné výsledky žiakov? Kládli sme si tieto a podobné otázky, ktoré nás priviedli k realizácii výskumu priamo na základných školách. Práve z týchto dôvodov sme sa rozhodli zamerat' svoju pozornost' na problematiku zážitkového učenia sa v primárnom prírodovednom vzdelávaní.

\section{Metodológia výskumnej sondáže}

$\checkmark$ príspevku prezentujeme výskumnú sondáž, ktorá sa realizovala v rámci predvýskumu. Ciel'om výskumnej sondáže bolo overit' v edukačnej praxi efektívnost' implementácie metód zážitkového učenia sa na hodinách prírodovedy so zretel'om na rozvíjanie kompetencií žiaka mladšieho školského veku. Výskumná sondáž bola realizovaná v roku 2019. Výskumný súbor bol tvorený žiakmi 4. ročníka ZŠ. Vo výskumnej sondáži bol využitý príležitostný a kvótny výber. Výskumnú vzorku tvorili dve rovnocenné skupiny žiakov, 15 žiakov kontrolnej skupiny a 16 žiakov experimentálnej skupiny. Hlavnou výskumnou metódou bol pedagogický kváziexperiment. $V$ experimentálnej skupine boli realizované proponované vyučovacie hodiny z vybranej témy prírodovedy s využitím zážitkových metód.

S ohl'adom na determinovaný ciel' výskumnej sondáže sme sformulovali výskumnú otázku kauzálneho naturelu: Aká je účinnost' zážitkových metód na hodinách prírodovedy v porovnaní s klasickými vyučovacími metódami z hladiska učebných výsledkov žiakov? V súvislosti s realizovanou výskumnou sondážou sme verifikovali stanovenú hypotézu: Vyučovanie pomocou zážitkových metód na hodinách prírodovedy bude efektívnejšie z hladiska učebných výsledkov žiakov ako vyučovanie pomocou klasických vyučovacích metód.

Z uvedenej výskumnej hypotézy vyplývajú štatistické hypotézy:

$\mathrm{H}_{0}$ : $\mathrm{Na}$ hodinách prírodovedy neexistuje štatisticky významný rozdiel $v$ učebných výsledkoch žiakov.

$\mathrm{H}_{1}$ : $\mathrm{Na}$ hodinách prírodovedy existuje štatisticky významný rozdiel $v$ učebných výsledkoch žiakov.

Na analýzu výsledkov bol využitý Kolmogorov - Smirnov test a T-test.

\section{Výskumné zistenia}

Vzhl'adom k obmedzenému rozsahu príspevku budeme uvádzat' len výber získaných dát a naše základné zistenia. 
V experimentálnej skupine sme overovali účinnost' navrhnutých projektov vyučovacích hodín prírodovedy vo vyučovaní témy Planéta Zem, v ktorých boli implementované zážitkové metódy. $V$ kontrolnej skupine prebiehalo za rovnakých časových podmienok vyučovanie nového učiva Planéta Zem pomocou klasických metód. Pretest v obidvoch skupinách bol zameraný na zhodnotenie úrovne dosiahnutých vedomostí z vyučovacieho predmetu prírodoveda. Následne bol realizovaný projekt experimentálnej činnosti (Tab. 1), po ktorom nasledoval v obidvoch skupinách posttest.

Tab. 1: Projekt kváziexperimentu

\begin{tabular}{|c|c|c|c|}
\hline & Pretest & Pôsobenie & Posttest \\
\hline $\begin{array}{c}\text { Experimentálna } \\
\text { skupina }\end{array}$ & áno & $\begin{array}{c}\text { Pôsobenie A } \\
\text { vyučovanie novej učebnej látky Planéta Zem pomocou } \\
\text { zážitkových metód }\end{array}$ & áno \\
\hline $\begin{array}{c}\text { Kontrolná } \\
\text { skupina }\end{array}$ & áno & $\begin{array}{c}\text { Pôsobenie B } \\
\text { vyučovanie novej učebnej látky Planéta Zem pomocou } \\
\text { klasických metód }\end{array}$ & áno \\
\hline
\end{tabular}

Konzekventné porovnanie numerických výsledkov vstupného a výstupného merania vedomostí žiakov prostredníctvom testu ukazuje graf 1.

Z uvedeného grafu 1 vyplýva, že obe výskumné skupiny boli pred začatím experimentálneho pôsobenia paralelné. Po ukončení experimentálneho pôsobenia a výstupnom meraní sa však experimentálna skupina zlepšia $v$ učebných výsledkoch o $3,4227 \%$, zatial' čo kontrolná skupina sa zhoršila až o 30,2734\%. Numerické výsledky oboch meraní zobrazuje tabul'ka č. 2.

Graf 1: Aritmetické priemery pretestov a posttestov

Z uvedeného grafu 1 vyplýva, že obe výskumné skupiny boli pred začatím

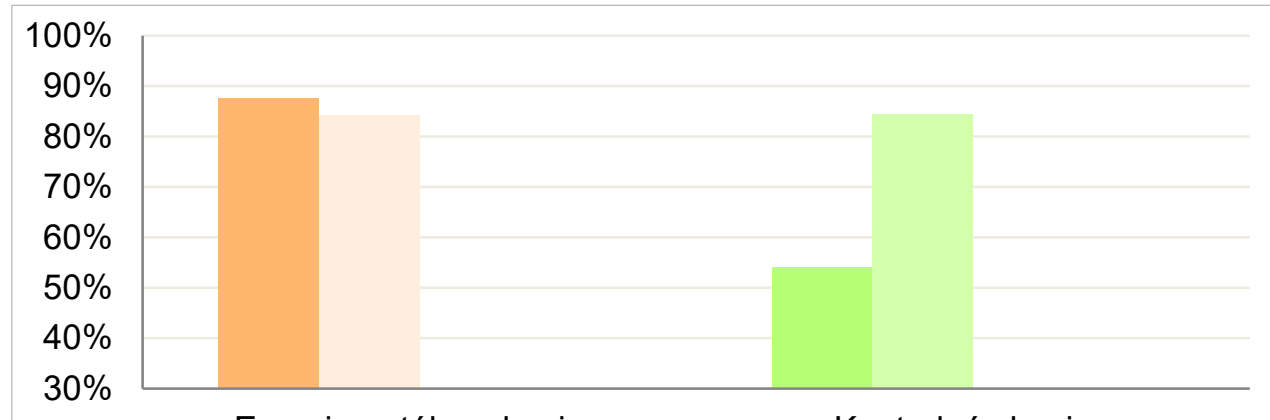

Experimentálna skupina

Kontrolná skupina

Pretest $\square$ Posttest $\square$ Pretest2 $\square$ Posttest2

experimentálneho pôsobenia paralelné. Po ukončení experimentálneho pôsobenia a výstupnom meraní sa však experimentálna skupina zlepšia v učebných výsledkoch o 
$3,4227 \%$, zatial' čo kontrolná skupina sa zhoršila až o $30,2734 \%$. Numerické výsledky oboch meraní zobrazuje tabul'ka č. 2.

Tab. 2: Numerické výsledky kváziexperimentu

\begin{tabular}{|l|l|l|l|l|}
\hline & $\begin{array}{l}\text { Počet } \\
\text { subjektov }\end{array}$ & $\begin{array}{l}\text { Aritmetický } \\
\text { priemer v \% } \\
\text { Pretest }\end{array}$ & $\begin{array}{l}\text { Aritmetický } \\
\text { priemer v \% } \\
\text { Posttest }\end{array}$ & $\begin{array}{l}\text { Rozdiel pretest } \\
- \text { posttest }\end{array}$ \\
\hline $\begin{array}{l}\text { Experimentálna } \\
\text { skupina } \\
\text { Kontrolná } \\
\text { skupina }\end{array}$ & 15 & 84,2856 & 87,7083 & 3,4227 \\
\hline
\end{tabular}

Pred zvolením adekvátneho štatistického testu vhodného $\mathrm{k}$ spracovaniu údajov kváziexperimentu, bolo potrebné zistit' či analyzované údaje majú alebo nemajú normálne rozdelenie. K tomu sme využili Kolmogorov - Smirnov test, ktorý nám potvrdil, že analyzované údaje normálne rozdelenie majú. Preto sme pre analýzu delimitovaných štatistických hypotéz využili test parametrický - konkrétne T-test pri nerovnosti rozptylov, ktorým sme komparovali učebné výsledky žiakov medzi experimentálnou a kontrolnou skupinou.

Tab. 3: Štatistický významný rozdiel medzi experimentálnou a kontrolnou skupinou

\begin{tabular}{|l|l|l|l|l|}
\hline & $p$-value & $\alpha$ & Porovnanie & Prijímame \\
\hline Pretest & 0,988 & 0,05 & $p<\alpha$ & $\mathrm{H}_{0}$ \\
Posttest & $000^{*}$ & & $\mathrm{p}<\alpha$ & $\mathrm{H}_{1}$ \\
\hline
\end{tabular}

p-value $=p$ hodnota

$\alpha=$ hladina významovosti

* ide o hodnotu menšiu ako 0,0001

Ako znázorňuje tabul'ka 3, pri preteste na základe nerovnosti $p=0,988>\alpha=0,05$ platí, že neexistuje štatisticky významný rozdiel $v$ učebných výsledkov medzi experimentálnou a kontrolnou skupinou, ktoré boli vyučované klasickými vyučovacími metódami. Avšak pri postteste na základe nerovnosti $\mathrm{p}<0,0001<\alpha=0,05$ platí, že existuje štatisticky významný rozdiel v učebných výsledkoch medzi experimentálnou a kontrolnou skupinou. Tu sa nám potvrdilo, že zážitkové metódy implementované do vyučovania prírodovedy majú eklatantne vplyv na učebné výsledky žiakov a dokázal sa štatisticky významný rozdiel medzi klasickou a zážitkovou formou vzdelávania.

Ďalej nás zaujímalo, aká je dištinkcia v učebných výsledkoch žiakov štvrtého ročníka a ktoré metódy vyučovania sú efektívnejšie. Pokračovali sme tak $v$ analýze posttestu na báze deskriptívnej štatistiky, $v$ rámci ktorej sme využili priemer bodov z výstupného merania, ich minimálnu i maximálnu hodnotu. Numerické výsledky zobrazuje tabul'ka 4. 
Tab. 4: Deskriptívna štatistika posttestu

\begin{tabular}{|l|l|l|l|l|}
\hline \multicolumn{2}{|l|}{} & Priemer & Minimum & Maximum \\
\hline \multirow{3}{*}{ Posttest } & Experimentálna skupina & 14,0333 & 9,5 & 16 \\
& Kontrolná skupina & 8,6563 & 4,5 & 12,5 \\
\hline
\end{tabular}

Ako ilustruje tabul'ka 4, priemerné učebné výsledky v prípade experimentálnej skupiny sú o $38,28 \%$ vyššie ako v kontrolnej skupine. Výrazný rozdiel môžeme vidiet' aj v prípade minimálnych učebných výsledkov, ktoré sú $\mathrm{v}$ kontrolnej skupine $\mathrm{v}$ porovnaní $\mathrm{s}$ experimentálnou skupinou o 47,67 \% menšie.

Po spracovaní získaných dát sa preukázal štatistický významný rozdiel v prospech experimentálnej skupiny, ktorá dosiahla lepšie učebné výsledky ako kontrolná skupina. Za týchto okolností sme platnost' $\mathrm{H}_{0}$ zamietli a prijali platnost' alternatívnej hypotézy $\mathrm{H}_{1}$, ktorou sme predpokladali, že na hodinách prírodovedy existuje štatisticky významný rozdiel $v$ učebných výsledkoch žiakov a akceptujeme tak tvrdenie, že vyučovanie pomocou zážitkových metód na hodinách prírodovedy je efektívnejšie z hl'adiska učebných výsledkov žiakov ako vyučovanie pomocou klasických vyučovacích metód. Považujeme tak za nevyhnutné implementovat' do edukačného procesu v primárnom prírodovednom vzdelávaní metódy zážitkového učenia sa. Ak chceme, aby si žiaci vytvárali pozitívny vzt'ah k prírode a rozvíjali sme u nich záujem o poznávanie prírody, jej javov a zákonitostí, je potrebné vniest' a vnášat' do edukačného procesu zážitky.

\section{Záver}

Na základe zistení z výskumnej sondáže môžeme konštatovat', že je adekvátne pokračovat' $v$ realizovaní výskumu v týchto intenciách, pričom využijeme širšiu výskumnú vzorku, aby sme mohli výsledky generalizovat'. Zároveň chceme apelovat' na skutočnost', že efektívnost' metód zážitkového učenia sa neprejaví u žiakov len v kognitívnej oblasti. $\checkmark$ realizovanom výskume tak d’alej pokračujeme $v$ zist'ovaní efektívnosti týchto metód pri rozvíjaní prírodovednej gramotnosti žiakov aj v afektívnej a konatívnej oblasti.

Príroda poskytuje podnety a priestor pre mnohostranné zážitkové učenie sa žiakov. Učitel' má pritom osobitné postavenie a môže metódy zážitkového učenia sa využívat' ako efektívny prostriedok na rozvíjanie ich prírodovednej gramotnosti. Do edukačného procesu môže v tomto kontexte implementovat' skúsenostné vyučovanie, činnostne zamerané vyučovania či bádatel'sky orientovaného vyučovania, v ktorom majú žiaci priestor na aktívnu činnost'. V prepojení so získanými skúsenost'ami a zážitkami si zároveň efektívne rozvíjajú prírodovednú gramotnost'. Učitel' primárneho vzdelávania má možnost' dat' každému jednému žiakovi rovnakú šancu pre získanie vedomostí, zručností a rozvíjanie svojich schopností. Je len v jeho rukách ako vyzdvihne potenciál každej jednej prírodovednej témy a bez ohl'adu na jej náročnost' ju primerane žiackym schopnostiam a možnostiam ozrejmí i priblíži. Zážitkové aktivity, starostlivo vyberané a rezultované z okruhu žiackych záujmov, neopísatel'ne vplývajú na utváranie si pozitívneho vzt’ahu k prírode, pričom samotná priaznivá edukácia nemusí bezpodmienečne prebiehat' len $v$ teréne, ale i v školskej triede, do ktorej je príroda v rámci možnosti prenesená. Žiaci poznávajú jej krásu, odhal'ujú jej zákonitosti pomocou svojich zmyslov a vlastnej aktivity. Metódy zážitkového učenia sa ponúkajú širokospektrálnu paletu činností, ktoré môžu byt' zamerané na rozvoj nižších i vyšších kognitívnych funkcií u žiakov, pričom sa v činnosti rozvíjajú aj d'alšie klúčové kompetencie, čo je prínosom pre vzrast prírodovednej gramotnosti a ústredným ciel'om moderného vzdelávania. 


\section{Pod'akovanie}

Príspevok vznikol v rámci grantovej úlohy VEGA č. 1/0624/20 Regionálna identita ako súčinný faktor rozvíjania environmentálnej gramotnosti v kontexte primárnej edukácie.

\section{Literatúra}

Brtnová-Čepičková, I. (2005). Aktivní konstrukce přírodovědného poznání žáků primární školy. Ústí nad Labem: Acta Universitatis Purkynianae.

Doušková, A., \& Kružlicová, M. (2011). Edukačná aktivita a zážitkové učenie sa v materskej škole. Pedagogické vedy. Banská Bystrica: Pedagogická fakulta - OZ Pedagóg.

Gavora, P. (2007). Naivné teórie diet’at’a. In Trubíniová, V. et al.: Predškolská pedagogika. Terminologický a výkladový slovník (s. 301-302). Ružomberok: PF KU v Ružomberku.

Houška, T. (1991). Škola hrou. Praha: Tomaš Houška.

Kariková, S. (2002). Kapitoly z pedagogickej psychológie. Žilina: IPV.

Kariková, S.(2001). Zážitkové učenie sa a jeho aplikácia v pedagogickej praxi. In Inovácie v edukácii a v príprave učitelov (s. 36-41). Banská Bystrica: Pedagogická fakulta Univerzity Mateja Bela.

Kolb, D. A. (1984). Experiential learning: Experience as the source of Learning and Development. Nee Jersev : Englewood Cliffs, Prentice-Hall, Inc.

Macko, J., \& Blahútová, D. (2010). Implementation the cycle of substances in science education by project teaching. Informatologia, 43(3), 236-239.

McLeod, S. A. (2017). Kolb - learning styles. [online]. SimplyPsychology : simplypsychology.org, /website/. Dostupné na https://www.simplypsychology.org/learning-kolb.html

Osborne, J., Simon, S. \& Collins, S. (2003). Attitudes towards science: a review of the literature and its implications. In International Journal of Science Education, 25(9), 1 049-1 079.

Ramsden, J. M. (1998). Mission impossible?: Can anything be done about attitudes to science? In International Journal of Science Education, 20(2), 125-137.

Roberst, D. A. (2007). Scientific literacy/Science literacy. Handbook of Research on Science Education. Dostupné na http://faculty.education.ufl.edu/tsadler/RobertsSciLit.pdf

Svobodová, J. (2013). Perspektivy a koncepce prrírodovědného vzdělávání. Hradec Králové: European Insitute of Education.

Thomková, A. a kol. (2012). Rámec profesních kvalit učitele. Praha: Národní ústav pro vzdělávání.

Uhrinová, M. (2015). Kulturelle Aspekte der regionalen Erziehung in den Dimensionen der Primarstufe. Wien : Internationale Stiftung Schulung, Kunst.

Vargová, M. (2012). Multikultúrna výchova a jej aplikácia v predprimárnom vzdelávaní. 1. vyd. Ružomberok: Verbum - vydavatel'stvo Katolíckej univerzity v Ružomberku.

\section{Adresy autorov}

\section{PaedDr. Miriam Uhrinová, PhD.}

Katedra predškolskej a elementárnej pedagogiky, Pedagogická fakulta, KU v Ružomberku

Hrabovská cesta 1, 03401 Ružomberok

miriam.uhrinova@ku.sk 
Mgr. Ivana Prachárová

Katedra predškolskej a elementárnej pedagogiky, Pedagogická fakulta, KU v Ružomberku

Hrabovská cesta 1, 03401 Ružomberok

ivuska.pracharova@gmail.com

\section{PaedDr. Ing. Jan Tirpák}

Katedra speciální a sociální pedagogiky, Pedagogická fakulta, UJEP v Ústí nad Labem Hoření 13, 40011 Ústí nad Labem

JanTirpak@seznam.cz 


\title{
SÚČASNÁ ÚLOHA A POSTAVENIE UČITELA ANGLICKÉHO JAZYKA NA STREDNEJ ODBORNEJ ŠKOLE
}

\section{THE CURRENT ROLE AND POSITION OF AN ENGLISH LANGUAGE TEACHER AT A SECONDARY TECHNICAL SCHOOL}

\author{
Michaela Zajacová \\ Stredná priemyselná škola dopravná, Trnava
}

\begin{abstract}
:
Given that English is currently the world's number one language of communication, its compulsory teaching in Slovakia is incorporated in the state education programme for both primary and secondary schools on the basis of the Common European Framework of Reference for Languages (CEFR). At secondary schools, it is then a compulsory school-leaving language for most students, while at technical and vocational schools students must graduate at level B1, or they can choose a higher voluntary level B2. As students come to the first year of high school with different levels of English, it is up to the teacher to evaluate such a situation and proceed in class so that after four years of study all students are able to use their acquired language skills and competences at the minimum required level $\mathrm{B} 1$ and to prove them not only during the graduation exam, but also in real life. However, this task of the teacher is not always easy, as even in today's age of modern technology and greater access to the English language through the media, some students are not motivated to further develop or use it. Other students, on the other hand, think that they speak it better and no longer need to improve in class, as they perceive the English language through various media - the so-called 'outside the classroom' learning. In this case, the question arises as to the role and position of an English teacher at a secondary technical or vocational school, where technical subjects are also a priority and pupils are often burdened with a high number of lessons in their time-table.
\end{abstract}

\section{Key words:}

English language teacher, the role and position of the teacher, secondary technical school

\section{Úvod}

Dôležitost' vyučovania cudzích jazykov na slovenských stredných odborných školách vždy stála o čosi viac vúzadí v porovnaní s dôležitost'ou vyučovania odborných predmetov. Toto ponímanie bolo vcelku logické v dobe, ked' slovenský trh práce nebol natol'ko prepojený s tým európskym alebo svetovým tak, ako je tomu v súčasnosti. Navyše, študenti stredných odborných škôl musia absolvovat' povinnú maturitnú skúšku z cudzieho jazyka minimálne na úrovni B1 podla Spoločného európskeho referenčného rámca - d’alej len SERR (Vyhláška č.318/ 2008, §7, ods. 2 b a ods. 10), čo znamená, že sú okrem ústnej formy internej časti maturitnej skúšky celoplošne testovaní aj písomnou formou, teda musia spĺňat' určité kritériá. Čo sa vyučovania cudzích jazykov týka, sú na študentov a aj na učitel'ov pri výstupe paradoxne kladené vyššie nároky, než ako je tomu pri odborných predmetoch (napr. podmienka s hodnotením známkou „dobrý“ pri ústnej 
forme maturitnej skúšky z CUJ: Vyhláška č.318/ 2008, § 15 ods. 1, 2, 4, 6, 7 a) a b) ).

Predpokladá sa, že okrem toho, že budú študenti kvalitne vzdelaní vo svojom odbore, budú schopní používat' minimálne jeden cudzí jazyk (v prvom rade anglický jazyk) slovom i písmom, bud' na povinnej úrovni B1 alebo dobrovol'nej B2, aby sa uplatnili či už v zahraničnej firme na Slovensku alebo vo firme v zahraničí, kde daný jazyk slúži ako komunikačný. Tu však učitelia narážajú na nezáujem mnohých študentov učit' sa anglický jazyk a aktívne ho používat'. Ich nízka motivácia a nezáujem častokrát vyplývajú zo slabých jazykových základov zo základnej školy, rodinného zázemia, náročnosti rozvrhu $\checkmark$ daný deň alebo neuvedomovania si možností využitia tohto jazyka v kontexte svojho osobného rozvoja alebo pracovných príležitostí. Napr. E. Petlák $(2016,55)$ v tejto súvislosti upozorňuje na sociálny a ekonomický kontext a nefunkčnost' spoločenského prostredia, v ktorom vel'a mladých l'udí žije. Tu sa stretávajú s úpadkom spoločenských hodnôt, krízou rodiny alebo nezamestnanost'ou. Autor konštatuje, že ak diet’a vyrastá $\checkmark$ rodine so zlými vzt'ahmi ako sú rozvedení rodičia alebo žije s jedným rodičom, je preňho t'ažie si vytvorit' vlastnú osobnost'. $V$ takomto prípade začne diet’a pochybovat' o význame školy a vzdelania alebo o zmysle života a prestane sa zaujímat' o školu a učivo. Podla autora je potom $v$ kontraste $s$ takto uvažujúcim diet'at'om myslenie mladého človeka alebo jeho rodiny, ktorá je v lepšej ekonomickej situácii a na vyššej sociálnej úrovni. Častokrát preto prehodnocuje, do akej miery je efektívny rozsah učiva, ktoré už nie je priamo potrebné pre profesionálny život. $\vee$ neposlednom rade autor pripomína, že k nezáujmu o školu prispieva aj dospievanie žiakov a vel'ké psychické, telesné, sociálne alebo intelektuálne zmeny, ktorými prechádzajú.

V tejto situácii si je viac ako vhodné položit' otázku, do akej miery k tomuto nezáujmu a nízkej motivácii prispieva aj učitel' anglického jazyka a vyučovacie metódy, ktoré na hodinách používa $v$ súlade so Spoločným európskym referenčným rámcom, Štátnym vzdelávacím programom a Katalógom cielových požiadaviek. Dnešnú generáciu stredoškolákov je náročnejšie zaujat' a motivovat' ako kedykol'vek predtým, nakol'ko neudržia dlho pozornost', sú zameraní viac na „akciu“ a striedanie aktivít. Zaujat' študentov $v$ súlade $s$ tromi už spomínanými dokumentmi môže preto pre pedagóga predstavovat' výzvu. Tí jazykovo zdatnejší študenti si často myslia, že sa už viac nenaučia, a preto nemajú tendenciu sa tol'ko pripravovat' a rozvíjat' sa ako tí slabší. Zaujímavé sú napríklad výsledky výskumu R. Rosenthala, E. Babada a D. Avni-Babada (2003), ktorý uvádza L. Krejčová $(2012,69)$. Daný výskum bol zameraný na interakciu učitel'ov stredných škôl a ich študentov, kde boli spozorované dve kategórie - podpora učenia a emocionálne podpora. Dospievajúci si podla autorky najviac cenili učitel'ov, ktorí boli na vyučovaní schopní kombinovat' obe zložky. Z výsledkov však prekvapivo vyplynulo, že zatial', čo dospievajúci takúto podporu zo strany učitel'a úplne akceptovali pri slabších študentoch, pri podpore tých lepších bol učitel' študentmi hodnotený dost' negatívne. Vyučujúci sa teda zamýšlajú, ako slabších aj lepších študentov vhodne motivovat' a aká úloha učitel'ovi cudzieho jazyka, v našom prípade anglického, v dnešnej dobe prináleží.

V súvislosti s uvedenou problematikou sme sa v našom príspevku rozhodli ozrejmit', aké podmienky sa v súčasnosti na stredných odborných školách pre vyučovanie anglického jazyka vytvárajú, aké kritériá by mal spĺnat' učitel' anglického jazyka a aké vyučovacie metódy na motiváciu študentov by mal na hodinách používat'.

\section{Podmienky vyučovania anglického jazyka na stredných odborných školách}

Vzhl'adom na to, že anglický jazyk patrí v súčasnosti k svetovému dorozumievaciemu jazyku číslo jeden, jeho povinné vyučovanie ako prvého cudzieho jazyka je na Slovensku zakomponované na základe ústredného dokumentu Rady Európy pre učenie sa, 
vyučovanie a hodnotenie úrovne ovládania cudzích jazykov - Spoločného európskeho referenčného rámca pre jazyky (SERR) - v štátnom vzdelávacom programe ako pre základné, tak aj stredné školy. Konkrétne SERR odporúča na stredných školách v prvom cudzom jazyku „redukovat' formálne vyučovanie CJ1 a namiesto toho používat' tento jazyk pravidelne alebo príležitostne na výučbu d’alšieho predmetu (forma odborne zameraného učenia a „bilingválneho vzdelávania“"“ (SERR, 2017, 175). V praktickom vyučovaní to znamená, že popri všeobecnej angličtine by sa v týždennej hodinovej dotácii mal nájst' priestor aj pre odborný jazyk, a tým pádom by sa takejto situácii mali prispôsobit' ako študenti, tak aj samotní vyučujúci.

Každá odborná škola má okrem povinnej hodinovej dotácie aspoň troch hodín prvého cudzieho jazyka týždenne k dispozícii aj tzv. „disponibilné hodiny“ v oblasti "Jazyk a komunikácia“, ktoré môže venovat' práve vyučovaniu prvého cudzieho jazyka. Škola, na ktorej pôsobíme, presadzuje už niekol'ko rokov posilnenie anglického jazyka ako prvého a zároveň maturitného cudzieho jazyka, čo vyučujúcim poskytuje väčší priestor na prípravu študentov. Taktiež sa vedenie školy rozhodlo využit' disponibilné hodiny na zaradenie odbornej angličtiny do vyučovania. V súčasnosti je hodinová dotácia všeobecnej angličtiny štyri hodiny týždenne pre prvý až tretí ročník, ku ktorým pribudla jedna hodina odbornej angličtiny týždenne. Celková týždenná hodinová dotácia anglického jazyka vo štvrtom ročníku je z tohto dôvodu na predmetnej škole pät' hodín týždenne. Navyše tu pôsobí aj jazyková škola, ktorá študentom odbornej školy ponúka zdokonal'ovacie kurzy pre nižšie ročníky a prípravný maturitný kurz pre študentov štvrtého ročníka. Z našej skúsenosti vyplýva, že takýto prístup nebýva na stredných odborných školách štandardný a vyučujúci anglického jazyka na škole si uvedomujú, že vyššia hodinová dotácia poskytuje lepšie možnosti na skvalitnenie prípravy študentov.

Ked'že títo prichádzajú do prvého ročníka strednej školy s rôznou úrovňou anglického jazyka, je na vyučujúcom, aby takúto situáciu vyhodnotil, a d’alej na hodinách postupoval tak, aby všetci žiaci po štyroch rokoch boli schopní využit' svoje nadobudnuté jazykové zručnosti a kompetencie na minimálnej požadovanej úrovni B1 a preukázat' ich nielen pri maturitnej skúške, ale aj v reálnom živote. K tejto snahe prispieva aj fakt, že sú na škole na hodinách anglického jazyka študenti od prvého ročníka rozdelení na „nižšiu“ a „vyššiu“ úroveň podla rozrad'ovacieho testu. Uvedené delenie má aj svoje nevýhody, jeho výhody však oceňujú najmä študenti v skupinách s „vyššou úrovňou“, z ktorých mnohí sa chcú pripravit' na vyššiu nepovinnú maturitnú úroveň B2. Škola ponúka štyri študijné odbory, z ktorých si túto možnost' vyberajú najmä študenti elektrotechnického odboru, ktorí anglický jazyk používajú aj mimo školu a sú si vedomí jeho dôležitosti pri svojom d’alšom štúdiu alebo $v$ pracovnom živote. Takto úrovňovo rozdelené skupiny sú homogénnejšie (napriek tomu sa aj v rámci jednej skupiny niekedy nachádzajú zdatnejší, aj menej zdatní študenti), a ako študenti, tak aj vyučujúci majú na hodinách lepšie podmienky na dosiahnutie spoločného ciel'a - prípravy na povinnú maturitnú skúšku z anglického jazyka.

\section{Súčasná úloha a postavenie učitel’a anglického jazyka vo vyučovacom procese}

Technologický pokrok v 21. storočí priniesol zmeny v spoločnosti, čo sa odzrkadluje aj na poli vzdelávania. S prínosom vel'kého množstva informácií prostredníctvom internetu a prístupom k novej technike sa zmenili okolnosti aj pre učitel'a cudzieho jazyka, pretože dnešná generácia študentov už s novými technológiami vyrastala, a preto na hodinách aj mimo nich potrebuje iný prístup na osvojenie si jazyka. Touto problematikou sa zaoberá aj SERR, pre ktorý súčasní učitelia cudzieho jazyka „predstavujú vzory tých rolí, ktoré učiaci sa môžu imitovat' vo svojom používaní jazyka“ a mali by si „uvedomit', že ich konanie, ..., je najdôležitejšou súčast'ou prostredia v procese učenia sa či osvojovania si jazyka“ (SERR, 2017, 147). Dokument Rady Európy sa v tomto bode zamýšla aj nad 
tým, aká dôležitost' by sa u učitel'a cudzieho jazyka mala klást' napr. na jeho schopnost' vyučovat', organizovat' prácu v triede, jeho štýl vyučovania, alebo na znalosti ohl'adom testovania a hodnotenia, jeho interkultúrne postoje, či schopnost' „vyrovnat' sa s individuálnym prístupom $v$ triede $k$ rozdielnym typom učiacich sa a $k$ učiacim sa $s$ odlišným typom schopností“ (SERR, 2017, 147). Referenčný Rámec sa takisto pýta, či by mal učitel' u žiakov „čo najlepšie rozvíjat' relevantné vlastnosti a schopnosti v priebehu individuálnej alebo skupinovej práce alebo práce vo dvojiciach“ (SERR, 2017, 147) pomocou dozerania na poriadok $v$ triede a udržiavania ho, pohybovania sa po triede a sledovania študentov, poskytovania individuálnych konzultácií alebo slúžit' ako konzultant a pomocník, prijat' názory študentov ohl'adom svojho učenia sa a koordinovat' ich činnost'. O niektorých z týchto bodov pojednávajú aj súčasní autori literatúry o všeobecnej didaktike, ale aj o didaktike anglického jazyka a snažia sa tieto otázky zodpovedat'.

Úlohou učitel'a sa vo svojej publikácii zaoberajú Z. Berová a P. Bero, ked' ponúkajú jednoduchú odpoved' a to, že učitel' ,má žiakom pomáhat' pri ich učení (sa). Dávat' podnety, ponúkat' možnosti, skrátka vytvárat' prostredie, v ktorom môžu realizovat' svoju prirodzenú snahu získavat' poznatky, zlepšovat' sa“ (2016, 91-92). R. Čapek $(2017,13)$ pridáva d’alšiu podstatnú myšlienku týkajúcu sa úlohy učitel'a vo vyučovaní svojho predmetu. Podla autora má učitel' odovzdávat' lásku k svojmu predmetu a to tak, že ho má rád, mal by predstavovat' človeka ,,z vnútra“, a mal by zo svojho odboru žiakom prezentovat' to najzaujímavejšie. Svoj pohl'ad R. Čapek uzatvára tým, že ak učitel' u žiakov posilňuje radost' z objavovania, odovzdáva zážitky, pozitívne emócie z úspechu a motivuje žiakov pri zlyhaniach, ktoré však netrestá, potom sa žiak na hodine bude dobre cítit', učit' sa nové veci a bude aj rád pracovat'. Myšlienku motivácie žiakov učitel'om pomocou záujmu o svoj predmet schval'uje aj E. Petlák (2011, 24), ked' sa odvoláva na M. Spitzera. Ten uvádza, že pre motiváciu nie je rozhodujúci ,,premietač fólií ... alebo dokonca prezentácia v Powerpointe, ale učitel' zaujatý svojím predmetom, učitel', u ktorého je centrom záujmu jeho predmet .... " (Jak uczy się mózg, 2007, 145).

J. Bérešová (2013) následne porovnáva súčasného učitel'a anglického jazyka s minulost'ou, ktorého bolo možné považovat' za „dirigenta“ alebo „velitel'a“. Jeho úlohou bolo prezentovat' informácie, kontrolovat' činnosti a hodnotit' správnost' výpovedí. $\checkmark$ ciel'ovom jazyku plnil funkciu korektora chýb a viedol a kontroloval správanie učiaceho sa. Učitel' väčšinou viedol interakciu, ktorá častokrát pripomínala policajné vyšetrovanie. ,Žiaci sa pri takomto type vyučovania mohli naučit' len to, čo vedeli ich učitelia a očakávalo sa, že sa naučia naspamät' všetko, čo im počas hodiny učitel' povedal. Za vel'mi dôležitú sa považovala správna odpoved"“ (Bérešová, 2013, 154-155).

Oproti tomu sa podla autorky od dnešného učitel'a cudzích jazykov očakáva, aby spracoval vel'ké množstvo informácií z niekol'kých vedomostných oblastí a mal informácie o žiakoch zahŕňajúce „psychologické faktory (schémy, kognitívny štýl a afektívne faktory), osobné potreby a spoločenské faktory (všeobecné prostredie a osobné prostredie)“ (Bérešová, 2013, 155). Ak má učitel' o žiakoch tieto vedomosti, mal by podl'a toho vybrat' vhodné materiály, predstavit' ich a vytvorit' emocionálne prostredie, ktoré prispieva k učeniu sa.

Autorka uvádza, že by si mal vyučujúci cudzích jazykov osvojit' širokú škálu rolí, ked'že vyučovací proces vyžaduje kreativitu a flexibilitu. Učitel' by mal byt' na hodine cudzieho jazyka manažér, pomocník alebo facilitátor, vzor, pozorovatel', informátor alebo zdroj, konzultant, poradca, sociálny pracovník a editor. Autorka takisto podotýka, že od dobrého učitel'a cudzích jazykov sa očakáva, že bude dobre ovládat' jazyk, bude oboznámený s teóriou vyučovania angličtiny, že bude poznat' koncept vzdelávania, rozumiet' ciel'u jazykového vzdelávania, bude empatický k žiakom, bude prirodzenou autoritou a mat' všeobecné znalosti. 
S J. Bérešovou v tomto ohl'ade súhlasí D. Gondová (2009), ktorá pripúšt'a, že sa úloha učitel'a vo vyučovaní cudzieho jazyka mení, a namiesto kontrolóra sa stáva facilitátorom, ktorý umožňuje žiakovi učit' sa. „Facilitátor potrebuje mat' kompetencie a zručnosti, ktoré sa predtým od učitela nevyžadovali. Jednou z nich je kladenie otázok, ktoré majú u žiaka vzbudit' záujem a zvedavost"“ (Gondová, 2009, 181). Učitel' by mal vytvárat' problémové situácie a pomáhat' žiakovi zvládnut' problémy vznikajúce pri učení sa. Taktiež je žiaka neustále potrebné podporovat' pri učení sa a pri hladaní vlastných riešení problémov. Navyše by sa mu malo ukázat', ako sa má učit. Facilitátor vytvára úlohy, ktoré umožňujú žiakom učit'sa, „stimulujú ich a motivujú ich mysliet'. Facilitačný prístup vo vyučovaní ... predstavuje základný princíp v rozvíjaní autonómneho učenia, pretože umožňuje vytvorit' podmienky na to, aby sa žiaci cez prirodzenú zvedavost' chceli dozvediet', naučit' viac" (Gondová, 2009, 181).

V rámci hesla ,,tvorit' - nenapodobňovat"“ predstavuje autorka J. Hanuliaková $(2015,57)$ aktívne učenie sa, ktoré samozrejme podporuje aktivitu žiakov. V rámci neho uvádza silný zmysel pre osobnú a kolektívnu zodpovednost', nezávislé vyjadrovanie, rozvíjanie sociálnych zručností, samostatné učenie sa a autonómiu v ňom. V. Janíková $(2012,50)$ sa navyše venuje konceptu vyučovania cudzích jazykov zameraného na žiaka. Tu konštatuje, že v súčasnom prístupe je pri vyučovaní cudzieho jazyka potrebné nielen inovovat' didaktické postupy alebo učebné materiály, ale zamerat' sa aj na individuálne zvláštnosti samotného žiaka. Následne môžeme hovorit' o komunikatívnom vyučovaní cudzieho jazyka zameraného na žiaka. V rámci neho autorka uvádza viacero typov vyučovania a vyučovacích metód spojených práve s individuálnymi zvláštnost'ami žiakov, d'alej je to projektové vyučovanie, učenie sa cudzieho jazyka pomocou riešenia úloh rečového typu (task-based language learning) patriacich k dialogickým metódam, koncept autonómneho učenia sa zdôrazňujúceho učebné stratégie alebo potreba celostného učenia (holistic learning) podporujúceho činnosti stimulujúce aj pravú hemisféru a nakoniec činnostné učenie (Learning by Doing), čo je celostné vyučovanie s aktívnym žiakom.

E. Homolová (2003) taktiež zdôrazňuje prípravu autonómneho žiaka, ktorý efektívne využíva svoje vedomosti a zručnosti aj mimo školu a je ochotný sa d'alej vzdelávat'. Autorka zdôrazňuje aj nezastupitel'né miesto učitel'a cudzích jazykov, ktoré nadobudol ,,nielen silou svojej osobnosti, výberom metód a postupov, znalost'ou potrieb žiaka a spoločnosti, ale aj didakticky správnym používaním vhodných učebných materiálov“ (Homolová, 2003, 6).

Zaujímavý je náhl'ad do analýzy (Medgyes, 1999), na ktorú sa odvoláva J. Bérešová $(2013,157)$. Táto analýza zahŕňala 86 percent nerodených (non-NESTS) a 14 percent rodených anglicky hovoriacich učitel'ov angličtiny (NESTs) z 11 krajín. Autorka upozorňuje, že podl'a dotazníkov, ktoré žiaci vyplňali, títo „nerozlišujú, či je učitel' angličtiny rodený alebo nerodený hovoriaci, ale uprednostňujú takých učitel'ov:

- $\quad$ ktorí sú priatel'skí

- vysvetlia učivo

- poskytnú dobré poznámky

- $\quad$ vedia, ako sa správat' k žiakom, ktorí dlhé hodiny sedia v laviciach

- $\quad$ nechajú žiakov, aby veci robili sami“.

V náväznosti na predchádzajúce uvedené poznatky spomenieme taktiež G. Lojovú a K. VIčkovú (2011), ktoré sa zaoberajú aspektom obsiahnutým aj v SERR, a to zistením učebných štýlov a stratégií žiakov, ktoré by mal učitel' cudzieho jazyka u žiakov na hodine aj pri učení sa mimo triedu („outside the classroom“) rešpektovat' a podporovat'. „V súčasnosti je nepopieratel'né, že učitelia cudzích jazykov si musia vedome rozvíjat' vnímavost' voči štýlom učenia svojich študentov“ (Lojová - Vlčková, 2011, 94). Autorky 
zároveň konštatujú, že je učitel' zodpovedný za vytváranie takých podmienok pre žiakov, aby sa mohli učit' jazyk spôsobom, ktorý najviac vyhovuje ich učebnému štýlu a mal by v premenlivých podmienkach pedagogického procesu prehodnocovat' kladné a záporné stránky týchto učebných štýlov a nechat' študentov profitovat' z kladných stránok svojho štýlu. Učitel'ovi odporúčajú prezentovat' učivo viacerými spôsobmi a striedat' rôznorodé aktivity, v čom poskytujú podporu aj mnohé nové jazykové materiály a učebnice. Žiaci by mali byt' o svojich učebných štýloch informovaní a uvedomovat' si ich. Čo sa týka učitel'a cudzieho jazyka, nemal by poznat' len učebný štýl svojich žiakov, ale aj svoj vyučovací štýl, pričom „učitel' podvedome či vedome uprednostňuje postupy a aktivity, ktoré sú efektívne pre jeho vlastné učenie, ktoré vyhovujú jeho štýlu učenia ... a v dôsledku týchto tendencií z jeho vyučovania získavajú ovel'a viac žiaci s rovnakým štýlom učenia sa“ (Lojová - Vlčková, 2011, 103), čoho by sa mal učitel' vyvarovat'.

Autorky upozorňujú aj na rozvíjanie stratégií učenia sa žiakov (úseky jednania, ktorými má byt' dosiahnutý určitý ciel') a úlohu učitel'a cudzieho jazyka v tomto ohl'ade. Podla autoriek by mal ,,pomôct' žiakom vytvorit' si efektívne stratégie učenia, ktoré budú sami používat' i po skončení školskej dochádzky“ (Lojová - Vlčková, 2011,103).

Z daných informácií vyplýva, že súčasný učitel' anglického jazyka by mal byt' nielen dobrý jazykový odborník, ale mal by byt' celkovo komplexnou osobnost'ou so všeobecnými znalost'ami a prihliadat' na „ludský rozmer" vo vyučovacom procese.

\section{Súčasné trendy vo vyučovaní anglického jazyka}

S osobnost'ou učitel'a anglického jazyka sú úzko späté aj vyučovacie metódy a prístupy, ktoré používa, aby žiakom umožnil čo najefektívnejšie si tento jazyk osvojit'. J. Bérešová $(2013,34)$ sa pri vyučovaní anglického jazyka v súčasnosti odvoláva na tzv. „Pometódové obdobie" 21. storočia, ktoré sa s ohl'adom na potreby súčasnej spoločnosti upriamuje na vyučovanie z komunikatívneho pohl'adu, teda nadväzuje na predchádzajúci komunikatívny prístup k jazyku. Ako klúčové zložky súčasných trendov vo vyučovaní anglického jazyka uvádza:

1. vyučovanie zamerané na žiaka

2. učenie sa zamerané na proces

3. zameranie sa na názory tých z „vnútra“ triedy, ktorí dokážu preskúmat’ a ohodnotit', zdôrazňujúc účastníkove názory a jedinečnost' každého kontextu

4. spojenie školy s vonkajším svetom, propagovanie holistického prístupu

5. orientáciu na postup od „celku k časti“ namiesto postupu od „časti k celku“

6. celoživotné vzdelávanie

7. učenie sa objavovaním.

Všetky uvedené zložky „Po-metódového“ obdobia sú v súlade s poznatkami, ktoré sme uviedli aj pri predchádzajúcich autoroch, a na ktoré nadväzuje aj R. Čapek $(2017,11)$, ked' pripomína, že sa učitel' nemusí nutne priklonit' k nejakej ,,reformnej pedagogike“, ale je ovel'a lepšie zvolit' eklektický alebo tzv. kombinačný prístup, teda svoje vyučovanie prispôsobit' danej situácii, triede a potrebám žiakov. Takéto vyučovanie autor nazýva aj „,suportívnym“ alebo ,,podporujúcim klimatickým vyučovaním“ - vyučovaním podporujúcim priaznivú pracovnú klímu v triede.

Autorka J. Bérešová (2013) k svojim predchádzajúcim myšlienkam doplňa, že súčasné trendy ku komunikatívnemu prístupu v anglickom jazyku sú založené na myšlienkach, ktoré podporujú:

- $\quad$ autonómiu učiaceho sa (nezávislost')

- $\quad$ učenie sa ako spoločenský proces (spolupráca)

- zahrnutie kurikula (jazyk viazaný na iné predmety, učenie sa založené na texte, projektové vyučovanie) 
- zameranie sa na význam (vyučovanie založené na obsahu)

- rôznorodost' (rôzne silné stránky učiaceho sa, oboznámenie sa so stratégiami učiacich sa)

- zručnosti v premýšl'aní (kritické a kreatívne myslenie)

- $\quad$ sebahodnotenie (žiacke zápisky, portfóliá)

- učitel'ov ako spolu-učiacich sa (facilitátorov - moderátorov).

Treba podotknút', že tieto zmeny v myslení neviedli k jednému modelu komunikatívneho jazykového vyučovania, ktorý by sa dal uplatnit' za každých okolností.

Podl'a autorky by mali dnešné jazykové osnovy „zahŕňat' systematické pokrytie všetkých rôznych zložiek komunikačných spôsobilostí, vrátane jazykových zručností, obsahu, gramatiky, slovnej zásoby, a funkcií" (Bérešová, 2013, 36).

\section{Záver}

Koncepcia vyučovania cudzích jazykov sa na Slovensku za posledné roky zmenila, pričom najväčší dôraz sa kladie na vyučovanie a učenie sa anglického jazyka ako povinného cudzieho jazyka už od základnej školy, čo je zakomponované aj v Štátnom vzdelávacom programe na základe odporúčaní Spoločného európskeho referenčného rámca pre jazyky (SERR). Stredná škola pritom slúži študentom ako posledný stupeň štátneho kontinuálneho organizovaného jazykového vzdelávania pred nástupom do zamestnania alebo na vysokú školu.

Z najnovších trendov jazykového vzdelávania vyplýva, že by mali vyučujúci cudzích jazykov študentov stredných škôl pripravit' na používanie cudzieho jazyka v reálnom živote, a to s prihliadaním na ich schopnosti, osobnost' alebo učebný štýl, vybudovali $\checkmark$ nich autonómiu pri budovaní si jazykových návykov a orientovali na nich vyučovanie $v$ rámci vyučovania zameraného na žiaka. Podmienky sú však na stredných školách rôzne.

Kým na gymnáziách pripravujú učitelia cudzích jazykov študentov s vedomím, že im najmä anglický jazyk bude slúžit’ ako „povinná výbava“ pri vysokoškolskom štúdiu alebo výmenných pobytoch $v$ zahraničí a povinnou maturitnou úrovňou je úroveň B2 podla SERR, na väčšine stredných odborných škôl sa vyučujúci musia viac snažit' vzbudit' u študentov o anglický jazyk záujem, nakol'ko sú pre týchto prioritou odborné predmety a často nemajú takú motiváciu sa anglický jazyk učit' a zlepšovat' sa v ňom, aj ked' si jeho dôležitost' uvedomujú a učia sa ho dlhšiu dobu.

Vd'aka zameraniu odborných škôl a týždennej hodinovej dotácii jazyka je potom pre študentov povinná maturitná úroveň B1, ktorá zodpovedá užívatel'ovi všeobecného jazyka. Aj na tomto type škôl sa však dá u študentov vybudovat' lepší vzt'ah k anglickému jazyku prostredníctvom hodín odbornej angličtiny, kde jazyk neslúži ako ciel', ale komunikačný prostriedok. Práve odborné zameranie cudzieho jazyka môže takýchto študentov zaujat', nakol'ko problematiku väčšinou poznajú už z odborných hodín a vyjadrenie v cudzom jazyku môže byt' pre nich zaujímavé aj vzhl'adom na možné praktické využitie odborného cudzieho jazyka na vysokej škole alebo pri komunikácii s anglicky hovoriacimi osobami v budúcom zamestnaní.

Motiváciu k učeniu sa a ovládaniu anglického jazyka u študentov stredných odborných škôl by mali vyučujúci tohto jazyka uplatňovat' v rámci možností na základe horeuvedenej modernej koncepcie cudzojazyčného vzdelávania nielen vo všeobecnom, ale aj tom odbornom jazyku. Ako však upozorňuje E. Patlák, nezáleží len na tom, aké motivačné metódy poznáme, ale aj na tom, ,že ten, koho motivujeme má svoje dôvody pre alebo proti motivovaniu“ $(2011,24)$. V našom prípade platí, že v prvom rade študent musí mat' vnútornú motiváciu učit' sa cudzí jazyk a uvedomit' si, že sa ho učí kvôli svojím potrebám, či už jeho využitiu v spomínanom budúcom zamestnaní, pri d’alšom štúdiu alebo pobyte v zahraničí. 


\section{Literatúra}

Berová, Z., Bero, P. 2016. Umenie byt' učitel'om. Bratislava: Raabe, ISBN 978-80- 8140233-3

Bérešová, J. 2013. English Language Teaching in Pre-service and In-service Teacher Training. Trnava: Typi Universitatis Tyrnaviensis, 236 s. ISBN 978-80-8082-769-4

Čapek, R. 2017. Líný učitel. Jak učit dobře a efektivně. Praha: Raabe, ISBN 978-807496-344-5

Gondová, D. 2009. Aktivizácia žiakov na hodinách cudzieho jazyka.

In: POKRIVČÁKOVÁ, S. a kol. Cudzie jazyky a kultúry v modernej škole (s. 161-181).

Brno: Masarykova univerzita PdF, ISBN 978-80-210-4974-112

Hanuliaková, J. 2015. Aktivizujúce vyučovanie. Bratislava: Iris, ISBN 978-80-8153-036-4 Homolová, E. 2003. Autentický materiál ako prostriedok rozvoja jazykových a komunikatívnych kompetencií žiakov. Banská Bystrica: Univerzita Mateja Bela, $98 \mathrm{~s}$. ISBN 80-8055-788-8. Dostupné na internete: [online] <http://www.ff.umb.sk/app/cmsFile.php?disposition=a\&ID=476>

Janíková, V. a kol. 2012. Výuka cizích jazyků. 2012. Praha: Grada, ISBN 978-80-2477380-3

Krejčová, L. 2012. Psychologické aspekty vzdělávání dospívajících. Praha: Grada, ISBN 978-80-247-7454-1

Lojová, G., Vlčková, K. 2011. Styly a strategie učení ve výuce cizích jazyků. Praha: Portál, 231 s. ISBN 978-80-7367-876-0

Petlák, E., Baranovská, A. 2016. Stres v práci učitel'a a syndróm vyhorenia. Bratislava: Wolters Kluwer, ISBN 978-80-8168-450-0

Petlák, E. a kol. 2011. Kapitoly zo súčasnej edukácie. Nitra: Iris, ISBN 978-80-89256-624

Spoločný európsky referenčný rámec pre jazyky. Učenie sa, vyučovanie, hodnotenie. 2017. Bratislava: Štátny pedagogický ústav, 255 s. ISBN 978-80-8118-201-3

\section{Adresa autora}

\section{Mgr. Michaela Zajacová}

Stredná priemyselná škola dopravná, Trnava

Študentská 23, 91745 Trnava

michaelazajacova2@gmail.com 